RODRIGO PRADO GONÇALVES

\title{
IMUNIDADE TRIBUTÁRIA ÀS CONTRIBUIÇÕES SOCIAIS DESTINADAS À SEGURIDADE SOCIAL DAS ENTIDADES BENEFICENTES DE ASSISTÊNCIA SOCIAL
}

DISSERTAÇÃO DE MESTRADO

Orientador: Professor Associado Dr. Paulo Ayres Barreto

UNIVERSIDADE DE SÃO PAULO

FACULDADE DE DIREITO

SÃO PAULO-SP

2015 


\title{
IMUNIDADE TRIBUTÁRIA ÀS CONTRIBUIÇÕES SOCIAIS DESTINADAS À SEGURIDADE SOCIAL DAS ENTIDADES BENEFICENTES DE ASSISTÊNCIA SOCIAL
}

\begin{abstract}
Dissertação apresentada à Banca Examinadora do Programa de Pós-Graduação em Direito, da Faculdade de Direito da Universidade de São Paulo, como exigência parcial para a obtenção do título de Mestre em Direito, na área de concentração Direito Econômico, Financeiro e Tributário, sob a orientação do Prof. Associado Dr. Paulo Ayres Barreto.
\end{abstract}


Banca Examinadora

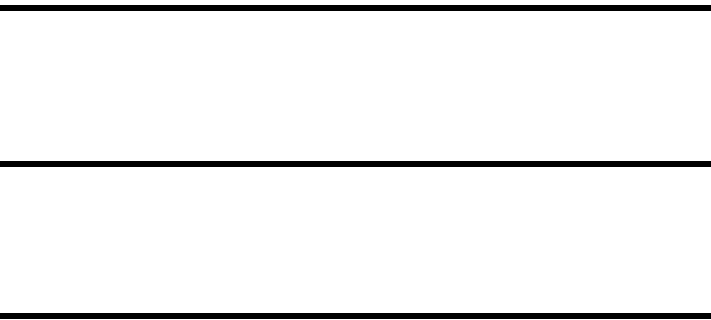




\section{AGRADECIMENTOS}

Inicialmente, gostaria de agradecer aos meus dois grandes amores: minha esposa, Renata Monteiro Seixas Gonçalves, que, ao longo de todo o caminho percorrido até a conclusão desta dissertação, apoiou-me e me deu forças para seguir sempre em frente, apesar das diversidades e dos obstáculos encontrados; e meu filho, Leonardo Seixas Gonçalves que, apesar da tenra idade, inspirou-me e representa o meu combustível não só para a vida pessoal, como também para a acadêmica e a profissional. Espero que esse trabalho motive-o a sempre evoluir e buscar o conhecimento.

A meus pais, Luiz Cézar Siqueira Gonçalves e Maria de Fátima Prado Gonçalves, e minha irmã, Roberta Prado Gonçalves, por todo o suporte dado ao longo dos anos e por sempre confiarem em minha capacidade e acreditarem em meus sonhos.

Aos queridos amigos e colegas de Felsberg e Pedretti Advogados e Consultores Legais que, direta ou indiretamente, contribuíram para a concretização deste trabalho acadêmico.

Ao querido amigo e mestre Nelson Mannrich, pelos valiosos conselhos, auxílio e honra ao ter compartilhado o mesmo ambiente de trabalho por mais de dez anos.

E, finalmente, mas não menos importante, ao Professor Doutor Paulo Ayres Barreto, pela orientação, sabedoria, disposição, oportunidade e convivência acadêmica ao longo dos últimos três anos. 


\section{RESUMO}

GONÇALVES, Rodrigo Prado. Imunidade tributária às contribuições sociais destinadas à seguridade social das entidades beneficentes de assistência social. 2015. 263 páginas. Mestrado. Faculdade de Direito, Universidade de São Paulo, São Paulo, 2015.

O presente trabalho científico possui por escopo estudar a imunidade tributária às contribuições sociais destinadas à seguridade social das entidades beneficentes de assistência social mencionada no artigo $195, \S 7^{\circ}$, da Constituição Federal de 1988 , bem como a abrangência dessa hipótese imunitória aplicável a essas espécies de entidades sem fins lucrativos. A imunidade tributária é uma norma de estrutura contida na Constituição Federal de 1988 que impede que União, Estados, Distrito Federal e Municípios tributem certas pessoas, fatos ou bens. Em outras palavras, as imunidades tributárias são normas constitucionais de incompetência tributária. A Constituição Federal de 1988 elenca inúmeras espécies de imunidades tributárias, dentre as quais a imunidade às contribuições sociais destinadas à seguridade social das entidades beneficentes de assistência social. Sempre que determinada pessoa jurídica enquadrar-se no conceito de entidade beneficente de assistência social e observar as exigências contidas na lei será ela imune. De acordo com a Carta Magna de 1988, consideram-se entidades beneficentes de assistência social as pessoas jurídicas que promovem as ações descritas em seu artigo 203. Neste trabalho científico, analisaremos se farão jus à imunidade tributária às contribuições sociais destinadas à seguridade social somente as entidades que possuem por objetivo as ações descritas no artigo 203 ou se o conceito de entidade beneficente de assistência social é mais abrangente. Afora enquadrar-se no conceito de entidade beneficente de assistência social, a instituição, para fins de fruição da imunidade às contribuições sociais destinadas à seguridade social, deve preencher alguns requisitos dispostos em lei. Mas que lei vem a ser esta: ordinária ou complementar? Consoante será demonstrado ao longo deste trabalho científico, tal lei só pode ser a complementar, haja vista esse ser o único instrumento normativo apto a estabelecer os requisitos a serem preenchidos visando ao gozo da imunidade às contribuições sociais destinadas à seguridade social, não obstante esse não ser o entendimento atual de grande parte dos integrantes do Poder Judiciário Brasileiro.

PALAVRAS-CHAVE: Imunidade Tributária. Seguridade Social. Instituições Sociais. Assistência Social. 


\begin{abstract}
GONÇALVES, Rodrigo Prado. Tax immunity on social insurance contributions for the social security of the charitable organization for social assistance. 2015. 263 pages. Master Degree. Faculty of Law, University of São Paulo, São Paulo, 2015.

This Master's Thesis aims at studying the tax immunity on social insurance contributions for the social security of those charitable organization for social assistance mentioned in section 195, §7 of the 1988 Federal Constitution, as well as the extent to which this hypothesis of immunity may be applicable to these types of non-profit making entities. Tax immunity is a structural regulation included in the 1988 Federal Constitution that prevents the Union, States, Federal District and Municipalities from taxing certain persons, events or assets. In other words, the tax immunities are constitutional norms establishing the non-applicability of taxes. The 1988 Federal Constitution lists a number of types of tax immunities, amongst which is the immunity to social insurance contributions for the social security of charitable organizations for social assistance. A company shall be declared immune whenever it is understood to fit into the concept of a charitable organization for social assistance and whenever it meets the requirements established by law. According to the 1988 Federal Constitution, charitable organizations for social assistance are considered to be those companies that perform the activities described in its article 203. In this Master's Thesis, we will be analyzing whether it is fair for the tax immunity on social insurance contributions for social security to be applicable only to those organizations with the objectives described in section 203, or if the concept of a charitable organization for social assistance is more wide reaching. Besides fitting into the concept of a charitable organization for social assistance, the organization, in order to take advantage of the immunity from social insurance contributions for social security, must meet all the requirements established by law. But which law should this be: an ordinary law or a complimentary law? Accordingly, it is to be demonstrated over the course of this Master's Thesis that a complimentary law can be the only one applicable, since this is the only regulatory instrument able to establish the requirements that need to be met to take advantage of the immunity to social insurance contributions for social security, despite this not being the current understanding of the majority of those forming the Brazilian Judiciary.
\end{abstract}

KEY WORDS: Tax Immunity. Social Insurance. Charitable Organizations. Social Assistance. 
"Talvez não tenha conseguido fazer o melhor, mas lutei para que o melhor fosse feito. Não sou o que deveria ser, mas Graças a Deus, não sou o que era antes.” (Marthin Luther King) 


\section{SUMÁRIO}

INTRODUÇÃO ....................................................................................................................... 13

CAPÍTULO I - SISTEMA CONSTITUCIONAL TRIBUTÁRIO BRASILEIRO..... 24

1.1. A discriminação das competências tributárias dos entes políticos - o Sistema

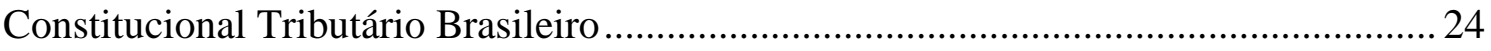

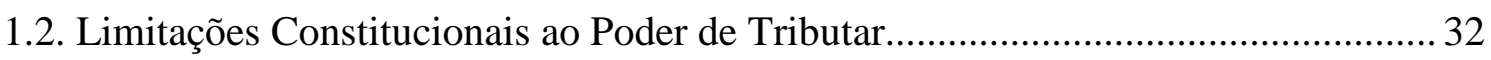

1.3. Relação entre Imunidade Tributária e Princípios Constitucionais Tributários.......... 36

1.3.1. Princípios Constitucionais Tributários aplicáveis às Imunidades Tributárias.... 37

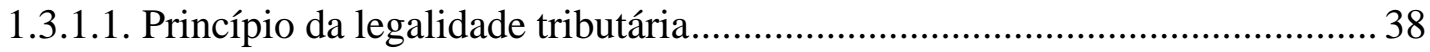

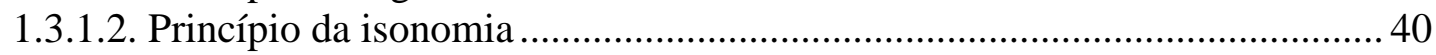

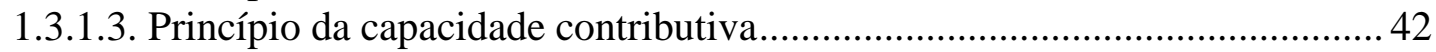

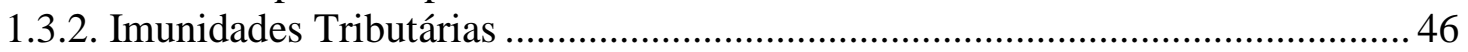

\section{CAPÍTULO II - CONCEITO DE IMUNIDADE TRIBUTÁRIA E QUESTÕES

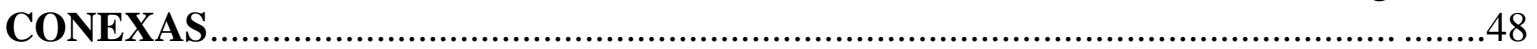

2.1. Natureza Jurídica e Conceito de Imunidade Tributária............................................. 48

2.1.1 Conceito de Imunidade Tributária adotado no presente trabalho científico .........52

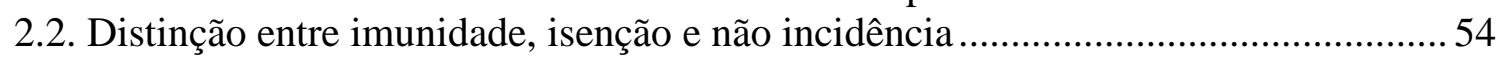

2.3. Imunidade Tributária: valor versus limite objetivo ..............................................59

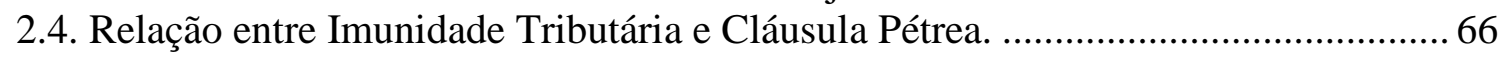

2.5. Relação entre imunidade tributária e livre concorrência ............................................. 78

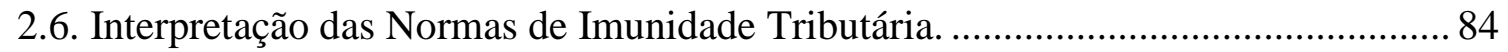

2.6.1. Posicionamento do Supremo Tribunal Federal acerca da interpretação das normas de imunidade tributária

\section{CAPÍTULO III - ESPÉCIES DE IMUNIDADES TRIBUTÁRIAS CONTIDAS NA

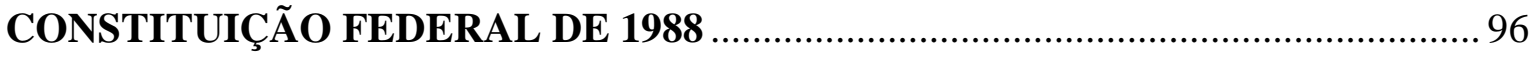

3.1. Classificação das Imunidades Tributárias. ................................................................. 96

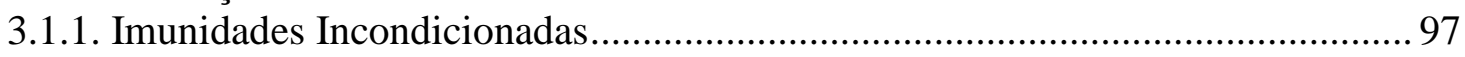

3.1.1.1. Imunidades tributárias incondicionadas do art. 150 da CF ......................... 98

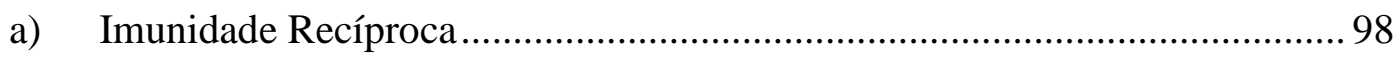

b) Imunidade dos templos de qualquer culto ............................................... 105

c) Imunidade do livro, jornal, periódico e do papel destinado a sua impressão 108

d) Imunidade de fonogramas e videogramas musicais e dos respectivos suportes materiais ou arquivos digitais que os contenham ............................................ 114

3.1.1.2. Outras hipóteses de imunidades tributárias incondicionadas referentes aos

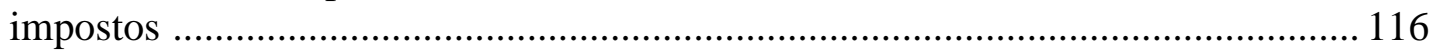

a) Imposto sobre Produtos Industrializados (IPI): ....................................... 116

b) Imposto sobre a Circulação de Mercadorias e sobre a prestação de Serviços de transporte interestadual e intermunicipal e de comunicação (ICMS): .................. 117

c) Imposto sobre a Transmissão Inter Vivos de Bens Imóveis (ITBI): ............ 119

d) Outros impostos exonerados............................................................ 120

3.1.1.3. Imunidades tributárias incondicionadas correspondentes às Contribuições

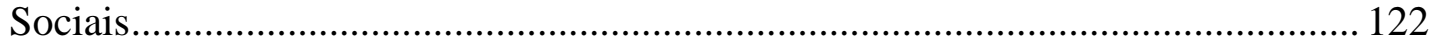

3.1.1.4. Imunidades tributárias incondicionadas correspondentes às taxas............. 124

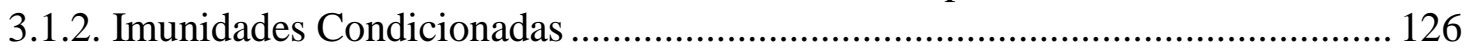


3.1.2.1. Imunidade condicionada do art. 150 da CF.

3.1.2.1.1. Imunidade tributária dos partidos políticos, inclusive suas fundações, das entidades sindicais dos trabalhadores, das instituições de educação e de assistência social, sem fins lucrativos

3.1.2.2. Outras hipóteses de imunidades tributárias condicionadas referentes aos impostos

3.1.2.3. Imunidades tributárias correspondentes às Contribuições Sociais ............. 134

3.1.2.4. Imunidades tributárias condicionadas correspondentes às taxas 135

\section{CAPÍTULO IV - ESCORÇO SOBRE A FIGURA DAS ENTIDADES BENEFICENTES DE ASSISTÊNCIA SOCIAL NO DIREITO BRASILEIRO ..................................... 137}

4.1. A Seguridade Social na Constituição Federal de 1988 ............................................ 137

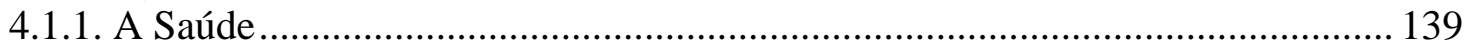

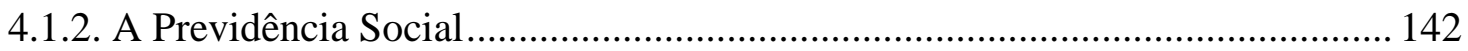

4.1.3. A Assistência Social ...................................................................................... 144

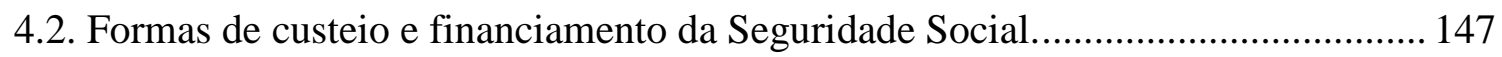

4.3. Conceito de Instituição de Assistência Social .......................................................... 153

4.4. Conceito de Entidade Beneficente de Assistência Social...................................... 158

4.5. Distinção entre entidade de assistência social, entidade beneficente de assistência

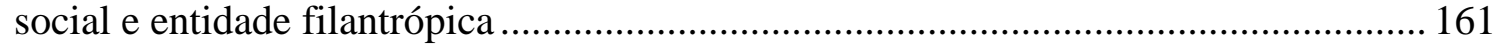

\section{CAPÍTULO V - IMUNIDADE TRIBUTÁRIA AOS IMPOSTOS DAS ENTIDADES BENEFICENTES DE ASSISTÊNCIA SOCIAL ........................................................ 164}

5.1. Imunidade Tributária aos Impostos das Entidades Beneficentes de Assistência Social 164

5.1.1. Amplitude da expressão "patrimônio, rendas e serviços relacionadas com as "finalidades essenciais" das entidades beneficentes de assistência social. 165

5.1.2 Instrumento normativo hábil a estabelecer os requisitos para a fruição da imunidade tributária aos impostos por parte das entidades beneficentes de assistência social: lei ordinária ou lei complementar?

5.2. Requisitos a serem preenchidos para fins de fruição da imunidade dos impostos das entidades beneficentes de assistência social ............................................................... 179

5.2.1. Não distribuição de parcela de seu patrimônio e renda, a qualquer título........ 180

5.2.2. Aplicação integral, no Brasil, dos recursos na manutenção dos seus objetivos

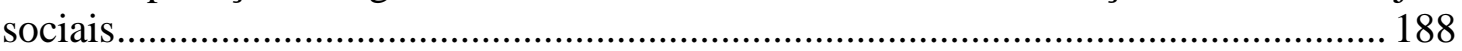

5.2.3. Escrituração de suas receitas e despesas em livros próprios............................. 191

CAPÍTULO VI - IMUNIDADE TRIBUTÁRIA ÀS CONTRIBUIÇÕES SOCIAIS DESTINADAS À SEGURIDADE SOCIAL DAS ENTIDADES BENEFICENTES DE ASSISTÊNCIA SOCIAL

6.1. Imunidade das Contribuições Sociais destinadas à Seguridade Social das Entidades

Beneficentes de Assistência Social 194

6.1.1. Natureza jurídica das contribuições Sociais destinadas à seguridade social: espécie autônoma de tributo? 196

6.2. Imunidade ou isenção das contribuições destinadas à seguridade social das entidades beneficentes de assistência social? 203

6.3. Instrumento normativo competente para regular as imunidades às contribuições sociais das entidades beneficentes de assistência social: lei ordinária ou lei complementar? .. 206 
6.4. A questão da observância dos requisitos dispostos no artigo 55, da Lei $\mathrm{n}^{\mathrm{o}} 8.212$, de 1991, para fins de fruição da imunidade às contribuições sociais destinadas à seguridade social das entidades beneficentes de assistência social 213

6.4.1. O julgamento do Recurso Extraordinário $\mathrm{n}^{\circ} 566.622$ e das Ações Diretas de Inconstitucionalidade $\mathrm{n}^{\text {os }} 2.028,2.036,2.621$ e 2.228

6.5. "Novos" requisitos a serem preenchidos pelas entidades beneficentes de assistência social, para fins de fruição do gozo da imunidade tributária às contribuições sociais destinadas à seguridade social - o artigo 29, da Lei $\mathrm{n}^{\mathrm{o}}$ 12.101/2009 


\section{INTRODUÇÃO}

Em decorrência de a Constituição Federal de 1988 ser classificada como rígida ${ }^{1}$, ela se fixa no topo da pirâmide do ordenamento jurídico brasileiro na condição de "lei fundamental e suprema", da qual todas as demais normas hierarquicamente inferiores extraem seu fundamento de validade ${ }^{3}$.

As normas jurídicas descritas na Constituição Federal de 1988 inserem-se dentre aquelas denominadas de "estrutura", na medida em que possuem por objeto estabelecer a maneira pela qual outras normas serão criadas ou, ainda, mencionar quando essas não devem ser criadas.

A Carta Magna de 1988 teve como uma de suas funções organizar o Estado por meio da criação dos Poderes Legislativo, Executivo e Judiciário, aos quais foram atribuídas competências (no sentido de aptidões) e determinadas atribuições.

Ao Poder Legislativo compete a criação de normas de conduta tendentes a regular as relações intersubjetivas entre os diversos sujeitos que compõem o Estado. O artigo $59^{5}$, da Constituição Federal de 1988 trata do processo legislativo e dispõe acerca dos veículos

\footnotetext{
${ }^{1}$ Vejam-se os ensinamentos de Paulo Bonavides e Paulo de Barros Carvalho acerca da rigidez da Constituição Federal de 1988, respectivamente:

“As Constituições rígidas, sendo Constituições em sentido formal, demandam um processo especial de revisão. Esse processo lhes confere estabilidade e rigidez bem superior àquela que as leis ordinárias desfrutam. Daqui procede pois a supremacia incontrastável da lei constitucional sobre as demais regras de direito vigente num determinado ordenamento. Compõe-se assim uma hierarquia jurídica, que se estende da norma constitucional às normas inferiores (leis, decretos-leis, regulamentos etc.), e que corresponde por igual uma hierarquia de órgãos. A conseqüência dessa hierarquia é o reconhecimento da 'superlegalidade constitucional', que faz da Constituição a lei das leis, a lex legum, ou seja, a mais alta expressão jurídica da soberania” (BONAVIDES, Paulo. Curso de Direito Constitucional. São Paulo: Malheiros Editores, 2007. p. 296).

"Por certo, se admitirmos a tese de que nossa Constituição é rígida e que o constituinte repartiu, incisivamente, as possibilidades legiferantes entre as entidades dotadas de personalidade política, cuidando para que não houvesse conflitos entre as subordens jurídicas estabelecidas no Estado Federal, a ilação imediata é em termos de reconhecer a vedação da delegabilidade, bem como a impossibilidade de renúncia. [...]”. (CARVALHO, Paulo de Barros. Curso de Direito Tributário. 26. ed. São Paulo: , 2014. p. 274).

2 DA SILVA, José Afonso. Curso de Direito Constitucional Positivo. São Paulo: Malheiros Editores, 2006. p. 46.

${ }^{3}$ KELSEN, Hans. Teoria Pura do Direito. 6. ed. Tradução de João Baptista Machado. São Paulo: Editora Martins Fontes, 1998. p. 223.

${ }^{4}$ CARVALHO, Paulo de Barros. Curso de Direito Tributário. 26. ed. São Paulo: Saraiva, 2014. p. 125.

5 “Art. 59. O processo legislativo compreende a elaboração de:

I - emendas à Constituição;

II - leis complementares;

III - leis ordinárias;

IV - leis delegadas;

$\mathrm{V}$ - medidas provisórias;

VI - decretos legislativos;

VII - resoluções.

Parágrafo único. Lei complementar disporá sobre a elaboração, redação, alteração e consolidação das leis".
} 
introdutores das normas no ordenamento jurídico pátrio: emenda constitucional, leis complementares, leis ordinárias, leis delegadas, medidas provisórias, decretos legislativos e resoluções.

Dentre os poderes para legislar, encontram-se aqueles relacionados ao "poder de tributar", ou seja, instituir os tributos que deverão ser recolhidos pelas pessoas físicas e/ou jurídicas a fim de possibilitar ao Estado o cumprimento das obrigações impostas pela Constituição (tais como prover os cidadãos com segurança, habitação, saúde, etc.). A instituição dos tributos dá-se por meio da outorga de competência tributária ${ }^{6}$ a União, Estados, Distrito Federal e Municípios. Tais entes devem respeitar os limites traçados pela própria Constituição Federal para a criação das receitas tributárias a serem utilizadas na satisfação dos anseios e das necessidades dos cidadãos.

Segundo Paulo Ayres Barreto,

o poder tributário - enquanto atributo da soberania de que dotado o Estado tem, no Brasil, o seu exercício disciplinado inteira e rigidamente pela Constituição. As pessoas político-constitucionais (União, Estados, Distrito Federal e Municípios) receberam, da Constituição, faixas circunscritas de competência tributária (isto é, competência legislativa para instituir tributos). Ao delinear o perímetro dessas competências, a Constituição estabeleceu contornos nítidos, de modo que o perfil por ela desenhado resulta da conjugação de prerrogativas expressas e rígidas, com vedações também claras e hirtas. Isso significa que o âmbito da competência tributária constitucionalmente outorgada é demarcado pelas balizas postas pela própria Constituição Federal". 7

Ocorre, no entanto, que a instituição de determinado tributo deve respeitar certos limites impostos pela própria Constituição. A esses limitadores da Constituição Federal de 1988 e doutrina pátria convencionaram-se denominar de "limitações constitucionais ao poder de tributar." 8

\footnotetext{
${ }^{6}$ De acordo com Paulo de Barros Carvalho, entende-se por competência tributária a "aptidão de que são dotadas as pessoas políticas para expedir regras jurídicas, inovando o ordenamento positivo. Opera-se pela observância de uma série de atos, cujo conjunto caracteriza o procedimento legislativo.

Por força do princípio da legalidade $\left(\mathrm{CF}\right.$, art. $\left.5^{\circ}, \mathrm{II}\right)$, a ponência de normas jurídicas inaugurais no sistema há de ser feita, exclusivamente, por intermédio de lei, compreendido este vocábulo no seu sentido lato. Em qualquer segmento da conduta social, regulada pelo direito, é a lei o instrumento introdutor dos preceitos jurídicos que criam direitos e deveres correlatos." (CARVALHO, Paulo de Barros. Curso de Direito Tributário. 26. ed. São Paulo: Saraiva, 2014. p. 269).

${ }^{7}$ BARRETO, Aires Fernandino; BARRETO, Paulo Ayres. Imunidades tributárias: limitações constitucionais ao poder de tributar. 2. ed. São Paulo: Dialética, 2001. p. 11).

${ }^{8}$ Veja-se, nesse sentido, a obra de Aliomar Baleeiro intitulada "Limitações Constitucionais ao Poder de Tributar", $7^{\mathrm{a}}$ edição revisada e complementada à luz da Constituição de 1988 até a Emenda Constitucional no 10/1996, atualizada pela Professora Mizabel Derzi (Rio de Janeiro: Editora Forense, 2010).
} 
Dentre as "limitações constitucionais ao poder de tributar" mais importantes em nosso ordenamento jurídico encontram-se as imunidades tributárias, que nada mais são do que normas constitucionais impeditivas à tributação de certas pessoas, fatos ou bens. Vale dizer que as imunidades tributárias são normas constitucionais de incompetência tributária ${ }^{9}$. A Constituição Federal de 1988 elenca imunidades ditas incondicionadas, as quais prescindem de regulamentação por meio de norma infraconstitucional, e imunidades ditas condicionadas que, por outro lado, necessitam de regulamentação.

Por conta de o presente trabalho científico voltar-se ao estudo das imunidades tributárias às contribuições sociais destinadas à seguridade social, as quais se enquadram no conceito de "imunidades condicionadas", envidamos nossos esforços na tentativa de analisar os inúmeros aspectos afeitos a essa figura desonerativa, bem como às demais questões conexas não só a essa figura desonerativa mas também às demais hipóteses de imunidade tributária.

De acordo com a Constituição Federal de 1988, existem cinco espécies de imunidades tributárias genéricas no que concerne aos impostos. São elas:

1. Imunidade recíproca ${ }^{10}$;

2. Imunidade dos templos ${ }^{11}$;

3. Imunidade dos partidos políticos, suas fundações, entidades sindicais dos trabalhadores e das instituições de educação e de assistência social, sem fins lucrativos ${ }^{12}$;

4. Imunidade dos livros, periódicos e o papel destinado a sua impressão ${ }^{13}$; e

5. Imunidade dos CDs e DVDs musicais produzidos no Brasil contendo musicais ou literomusicais de autores brasileiros ou obras interpretadas por artistas brasileiros ${ }^{14}$.

Afora as inúmeras outras hipóteses de imunidades de impostos e taxas dispostas ao longo do texto constuticional, há também a imunidade às contribuições sociais destinadas à seguridade social a que o artigo $195, \S 7^{\circ}$, da Constituição Federal de 1988 faz menção. ${ }^{15} \mathrm{E}$ é

\footnotetext{
${ }^{9}$ Corroboram esse entendimento, a título exemplificativo, Paulo de Barros Carvalho (CARVALHO, op. cit., p. 237), Aires F. Barreto e Paulo Ayres Barreto (BARRETO; BARRETO, op. cit., p. 12) e Roque Antonio Carraza (CARRAZA, Roque Antonio. Curso de Direito Constitucional Tributário. 29. ed. São Paulo: Malheiros Editores, 2013. p. 174).

${ }^{10}$ Artigo 150, inciso VI, alínea "a”, da Constituição Federal de 1988.

${ }^{11}$ Artigo 150, inciso VI, alínea "b", da Constituição Federal de 1988.

${ }^{12}$ Artigo 150, inciso VI, alínea "c", da Constituição Federal de 1988.

${ }^{13}$ Artigo 150, inciso VI, alínea "d", da Constituição Federal de 1988.

${ }^{14}$ Artigo 150, inciso VI, alínea "e”, da Constituição Federal de 1988.

15 Não obstante o artigo 195, $\$ 7^{\circ}$, da Constituição Federal fazer alusão ao termo "isenção", doutrina e jurisprudência são unânimes ao reconhecer se tratar de imunidade e não de isenção. Vejam-se, nesse sentido, as palavras de Paulo Ayres Barreto: "Desde logo, impõe-se referir que se trata de imunidade e não de isenção. Essa advertência é necessária porque, como se demonstrará, há um imenso fosso separando imunidade de isenção"
} 
justamente sobre essa espécie de limitação constitucional ao poder de tributar que o presente trabalho pretende focar seus esforços.

Não obstante a intensa discussão acerca das contribuições - na medida em que inexiste um posicionamento uníssono da doutrina e jurisprudência pátrias acerca dessa figura ${ }^{16}$, a qual é considerada por muitos doutrinadores como uma espécie autônoma de tributo ${ }^{17}$ e por alguns outros sequer possui natureza tributária ${ }^{18}$-, o presente trabalho procurará analisar sua natureza jurídica e a eventual aplicação sobre elas das normas jurídicas que tratam das imunidades tributárias.

As contribuições sociais destinadas à seguridade social, cujas materialidades encontram-se dispostas no artigo 195 da Constituição Federal de 1988, caracterizam-se pela afetação do produto de sua arrecadação para o financiamento da seguridade social, que "compreende um conjunto integrado de ações de iniciativa dos Poderes Públicos e da sociedade, destinadas a assegurar os direitos relativos à saúde, à previdência e à assistência social”, conforme definição trazida pelo artigo 194 da vigente Carta Magna.

Com efeito, prescreve o artigo $195, \S 7^{\circ}$, da Constituição Federal de 1988, que "são isentas de contribuição para a Seguridade Social as entidades beneficentes de assistência social que atendam as exigências estabelecidas em lei”. Dessa maneira, sempre que determinada pessoa jurídica enquadrar-se no conceito de entidade beneficente de assistência social e atender às exigências contidas na lei, será ela imune de tributação. De acordo com a Carta Magna de 1988, serão consideradas entidades beneficentes de assistência social as pessoas jurídicas que promoverem as ações descritas em seu artigo $203 .{ }^{19}$

(BARRETO, op. cit., p. 103). Vide, outrossim, decisão proferida pelo E. STF nos autos do MS 22.192-DF (DJ de 19.12.1996).

${ }^{16}$ Nesse sentido: HORVATH, Estevão. As contribuições na Constituição brasileira: ainda sobre a relevância da destinação do produto da sua arrecadação. In: Revista de Direito Tributário n. 100. São Paulo: Malheiros, 2008, p. 122 .

${ }^{17}$ Nesse sentido: Paulo de Barros Carvalho (CARVALHO, Paulo de Barros. Curso de Direito Tributário. 26. ed. São Paulo: Saraiva, 2014. p. 74-78); Sacha Calmon Navarro Coêlho (CÔELHO, Sacha Calmon Navarro. Curso de Direito Tributário Brasileiro. 10. ed. Rio de Janeiro: Forense, 2009. p. 405-408) e Roque Antônio Carrazza (CARRAZZA. Roque Antônio. Curso de Direito Constitucional Tributário. 29. ed. São Paulo: Malheiros, 2013. p. 595-670).

${ }^{18}$ Nesse sentido: Marco Aurélio Greco (Contribuições - uma figura sui generis). São Paulo: Dialética, $2000, \mathrm{p}$. 70); Luiz Mélega (Regime jurídico das contribuições na Carta Política de 1988. Direito Tributário Atual. v. 11/12. São Paulo: Resenha Tributária; Instituto Brasileiro de Direito Tributário, 1992, p. 3.294-3.295); Valdir de Oliveira Rocha (Contribuições sociais. In: MARTINS, Ives Gandra da Silva (coord.). Caderno de Pesquisas Tributárias. v. 17. São Paulo: Resenha Tributária, 1992. p. 302) e Wladimir Novaes Martinez, especificamente quanto às contribuições sociais (Natureza jurídica da contribuição previdenciária na Carta Magna de 1988. In: ROCHA, Valdir de Oliveira (coord.). Contribuições previdenciárias: questões atuais. São Paulo: Dialética, 1996. p. 244-245).

19 “Art. 203. A assistência social será prestada a quem dela necessitar, independentemente de contribuição à seguridade social, e tem por objetivos:

I - a proteção à família, à maternidade, à infância, à adolescência e à velhice; 
Ainda que o próprio texto constitucional elenque as entidades que se enquadrariam no conceito de instituições beneficentes de assistência social, o Poder Judiciário entendeu por ampliar esse rol e incluir as entidades que promovem a assistência educacional ou de saúde a menores, idosos, excepcionais ou pessoas carentes. Isso pode ser facilmente constatado pela análise da medida liminar concedida pelo Ministro Moreira Alves nos autos da ADI $n^{\circ} 2.028$, a qual suspendeu a eficácia de determinados dispositivos da Lei $\mathrm{n}^{\circ}$ 9.732/98, alterando o artigo 55 da Lei ${ }^{\circ}$ 8.212/91:

Do exame sistemático da Constituição, verifica-se que a Seção relativa à Assistência Social não é exauriente do que se deve entender como Assistência Social, pois, além de não se referir a carentes em geral, mas apenas a família, crianças, adolescentes, velhos e portadores de deficiência sem sequer exigir de todos estes que sejam carentes, preceitua, em seu artigo 203, que ela se fará independentemente de contribuição à seguridade social, a indicar que será gratuita, o que só se compatibilizará com o disposto no parágrafo único do artigo 149 - que permite que os Estados, o Distrito Federal e os Municípios instituam contribuição cobrada de seus servidores para o custeio, em benefício destes, de sistemas de previdência e assistência social - de se entender que, para a Constituição, o conceito de assistência social é mais amplo não só no doutrinário, mas também no adotado pelo artigo 203 para a disciplina específica prevista nele e no disposto que se lhe segue.

Por isso mesmo, em sua redação originária, o artigo 55 da Lei 8.212/91, que regulamentou as exigências que deveriam ser atendidas pelas entidades beneficentes de assistência social para gozarem de imunidade - isenção prevista na Constituição imunidade é, conforme entendimento já firmado por esta Corte - adotou conceito mais amplo de assistência social do que o decorrente do artigo 203 da Carta Magna, ao estabelecer, em seu inciso III, que uma dessas exigências para isenção (entenda-se imunidade) em favor das entidades beneficentes de assistência social seria a de ela promover a "assistência social beneficente, inclusive educacional ou de saúde, a menores, idosos, excepcionais ou pessoas carentes".

Dessa forma, entendeu o Supremo Tribunal Federal que o conceito de entidade beneficente de assistência social só pode ser entendido como abrangente de todas as entidades sem fins lucrativos que, embora exercendo suas atividades mediante remuneração aos que possam por elas pagar, atendam às necessidades básicas do ser humano, prestando serviços gratuitos aos carentes que deles necessitem, conforme hajam os recursos disponíveis.

II - o amparo às crianças e adolescentes carentes;

III - a promoção da integração ao mercado de trabalho;

IV - a habilitação e reabilitação das pessoas portadoras de deficiência e a promoção de sua integração à vida comunitária;

$\mathrm{V}$ - a garantia de um salário mínimo de benefício mensal à pessoa portadora de deficiência e ao idoso que comprovem não possuir meios de prover à própria manutenção ou de tê-la provida por sua família, conforme dispuser a lei." 
Como se não bastasse a necessidade de as entidades enquadrarem-se no conceito de "entidades beneficentes de assistência social", estabelecido em conjunto pelo artigo 203 da Constituição Federal de 1988 e pelo entendimento do Supremo Tribunal Federal, faz-se mister, a fim de gozar da fruição da imunidade das contribuições sociais, o atendimento aos requisitos dispostos em lei. Mas que lei vem a ser esta: ordinária ou complementar?

De acordo com o artigo 146, inciso II, da Constituição Federal de 1988, compete à lei complementar dispor acerca das limitações constitucionais ao poder de $\operatorname{tributar}^{20}$. A justificativa desse regramento reside no fato de que, na hipótese de o constituinte deixar a critério dos diversos poderes tributantes a fixação de requisitos necessários para o gozo da imunidade, poderia restar comprometida a uniformidade do tratamento tributário da matéria em todo o território nacional. Também, estabeleceriam-se tantos obstáculos à isenção de tributos que restaria frustrada a finalidade para a qual a imunidade foi prevista no texto constitucional $^{21}$.

Em virtude de o Código Tributário Nacional ter recebido o status de lei complementar com a promulgação da Constituição Federal de 1988, os requisitos para a fruição do gozo da imunidade são os dispostos no artigo 14 do Código Tributário Nacional ${ }^{22}$, com a redação que lhe foi dada pela Lei Complementar $n^{\circ} 104 / 2001$.

Assim, farão jus à imunidade tributária às contribuições sociais destinadas à seguridade social as entidades beneficentes de assistência social que:

\footnotetext{
20 “Art. 146. Cabe à lei complementar:

[...]

II - regular as limitações constitucionais ao poder de tributar".

21 Vejam-se as palavras de Aires F. Barreto e Paulo Ayres Barreto acerca desse tema: "O legislador constitucional, ao conferir à lei complementar a função de regular as limitações constitucionais ao poder de tributar, buscou manter a coerência da ordem jurídica e a eficácia do seu comando, evitando abusos que pudessem restringir o gozo da imunidade. Fosse possível estabelecer os requisitos para o gozo da imunidade, por intermédio de lei ordinária, estaríamos diante do caos. Isto porque cada ente tributante - União, Estados, Distrito Federal e Municípios - buscaria fixar as condições para o usufruto da imunidade constitucional. Cada uma dessas inúmeras leis (isto para não falar nos atos infralegais que se seguiriam) estabeleceria critérios e condicionantes os mais díspares para reger a matéria. Como não existe hierarquia entre as leis ordinárias dos diversos entes políticos, seria difícil precisar qual preceito deveria ser obedecido. Instalar-se-ia, de vez, nesse campo, total desordem no ordenamento jurídico brasileiro.” (BARRETO; BARRETO, op. cit., p. 25)

22 "Art. 14. O disposto na alínea c do inciso IV do artigo $9^{\circ}$ é subordinado à observância dos seguintes requisitos pelas entidades nele referidas:

I - não distribuírem qualquer parcela de seu patrimônio ou de suas rendas, a qualquer título;

II - aplicarem integralmente, no País, os seus recursos na manutenção dos seus objetivos institucionais;

III - manterem escrituração de suas receitas e despesas em livros revestidos de formalidades capazes de assegurar sua exatidão.

$\S 1^{\circ} \mathrm{Na}$ falta de cumprimento do disposto neste artigo, ou no $\S 1^{\circ}$ do artigo $9^{\circ}$, a autoridade competente pode suspender a aplicação do benefício.

$\S 2^{\circ}$ Os serviços a que se refere a alínea c do inciso IV do artigo $9^{\circ}$ são exclusivamente, os diretamente relacionados com os objetivos institucionais das entidades de que trata este artigo, previstos nos respectivos estatutos ou atos constitutivos."
} 
1. não distribuírem qualquer parcela de seu patrimônio ou de suas rendas, a qualquer título;

2. aplicarem integralmente, em território nacional, os recursos advindos da consecução do seu objeto social; e

3. manterem escrituração de suas receitas e despesas nos livros exigidos pela legislação pátria.

Afora esses critérios, atualmente, ditas entidades beneficentes de assistência social não poderão ter negado o reconhecimento da sua condição de entidade imune ${ }^{23}$.

Além disso, a Lei $\mathrm{n}^{\circ} 8.212 / 91$ dispunha em seu artigo 55 outros requisitos a serem preenchidos pelas entidades beneficentes de assistência social, com vista ao reconhecimento do gozo da imunidade tributária de ditas entidades ${ }^{24}$.

Em junho de 2014, após inúmeras discussões doutrinárias e judiciais - nas quais inclui-se o reconhecimento jurisprudencial de que o artigo 55 da Lei $\mathrm{n}^{\circ} 8.212 / 91$ é o instrumento normativo apto a estabelecer os critérios a serem observados pelas entidades beneficentes de assistência social visando ao gozo da imunidade contida no artigo $195, \S 7^{\circ}$,

${ }^{23}$ Diz-se atualmente, pois, até o presente momento, não existe nenhuma outra lei complementar, além do Código Tributário Nacional, dispondo sobre os requisitos a serem cumpridos visando à fruição do gozo da imunidade tributária.

24 “Art. 55. Fica isenta das contribuições de que tratam os arts. 22 e 23 desta Lei a entidade beneficente de assistência social que atenda aos seguintes requisitos cumulativamente:

I - seja reconhecida como de utilidade pública federal e estadual ou do Distrito Federal ou municipal;

II - seja portadora do Certificado e do Registro de Entidade de Fins Filantrópicos, fornecido pelo Conselho Nacional de Assistência Social, renovado a cada três anos;

II - seja portadora do Registro e do Certificado de Entidade Beneficente de Assistência Social, fornecidos pelo Conselho Nacional de Assistência Social, renovado a cada três anos;

III - promova a assistência social beneficente, inclusive educacional ou de saúde, a menores, idosos, excepcionais ou pessoas carentes;

III - promova, gratuitamente e em caráter exclusivo, a assistência social beneficente a pessoas carentes, em especial a crianças, adolescentes, idosos e portadores de deficiência;

IV - não percebam seus diretores, conselheiros, sócios, instituidores ou benfeitores, remuneração e não usufruam vantagens ou benefícios a qualquer título;

V - aplique integralmente o eventual resultado operacional na manutenção e desenvolvimento de seus objetivos institucionais apresentando, anualmente ao órgão do INSS competente, relatório circunstanciado de suas atividades.

$\S 1^{\circ}$ Ressalvados os direitos adquiridos, a isenção de que trata este artigo será requerida ao Instituto Nacional do Seguro Social-INSS, que terá o prazo de 30 dias para despachar o pedido.

$\S 2^{\circ} \mathrm{A}$ isenção de que trata este artigo não abrange empresa ou entidade que, tendo personalidade jurídica própria, seja mantida por outra que esteja no exercício da isenção.

$\S 3^{\circ}$ Para os fins deste artigo, entende-se por assistência social beneficente a prestação gratuita de benefícios e serviços a quem dela necessitar.

$\S 4^{\underline{0}}$ O Instituto Nacional do Seguro Social - INSS cancelará a isenção se verificado o descumprimento do disposto neste artigo.

$\S 5^{\circ}$ Considera-se também de assistência social beneficente, para os fins deste artigo, a oferta e a efetiva prestação de serviços de pelo menos sessenta por cento ao Sistema Único de Saúde, nos termos do regulamento.

$\S 6^{\circ} \mathrm{A}$ inexistência de débitos em relação às contribuições sociais é condição necessária ao deferimento e à manutenção da isenção de que trata este artigo, em observância ao disposto no § $3^{\circ}$ do art. 195 da Constituição". 
da Constituição Federal de 1988 -, o Supremo Tribunal Federal deu início ao julgamento do Recurso Extraordinário $\mathrm{n}^{\circ}$. 566.622, erigido à condição de repercussão geral, bem como do mérito das $\mathrm{ADI} \mathrm{n}^{\text {os }} 2.028,2.036,2.621$ e 2.228, as quais tratam justamente da constitucionalidade desse artigo 55 e de outros mais contidos em leis ordinárias que visam a estabelecer limites à fruição das imunidades tributárias às contribuições sociais destinadas à seguridade social das entidades beneficentes de assistência social.

Apesar de o artigo 55 ter sido revogado ${ }^{25}$ antes mesmo de o Supremo Tribunal Federal ter colocado uma pá de cal na discussão sobre a sua constitucionalidade ou não, a discussão acerca do ato normativo tendente a regulamentar a imunidade às contribuições sociais destinadas à seguridade social das entidades beneficentes de assistência social não terá seu fim. Isso ocorre visto que permanece em nosso ordenamento a discussão acerca do cumprimento ou não de pressupostos descritos em lei ordinária para que a entidade beneficente de assistência social tenha reconhecido o seu direito de usufruir da imunidade tributária contida na Carta Magna de 1988.

Os tribunais pátrios já se debruçaram sobre essa questão e muitos deles, ignorando totalmente o posicionamento doutrinário ${ }^{26}$ já firmado de que somente lei complementar pode dispor acerca dos requisitos para o gozo da imunidade, estão se posicionando no sentido de que, não cumpridos os requisitos contidos na Lei $\mathrm{n}^{\circ} 12.101 / 2009$, as entidades beneficentes de assistência social não farão jus à imunidade tributária das contribuições destinadas à seguridade social $^{27}$.

Dessa forma, apesar de a doutrina pátria ser uníssona no sentido de que os requisitos a serem cumpridos pelas entidades beneficentes de assistência social devem ser os contidos em

\footnotetext{
${ }^{25}$ Tal artigo foi revogado pela Lei $n^{\circ} 12.101$, de 30 de novembro 2009.

${ }^{26}$ Luís Eduardo Schoueri menciona em sua obra "Direito Tributário" que, não obstante o artigo 55 da Lei $\mathrm{n}^{\circ}$ 8.212/1991 ter sido revogado, tal celeuma não perdeu sua atualidade nem deixou de existir em nosso ordenamento, pois foi editada a Lei $\mathrm{n}^{\circ} 12.101 / 2009$, a qual estabelece inúmeros requisitos a serem preenchidos pelas entidades beneficentes de assistência social para fruição da imunidade tributária das contribuições sociais: "Deve-se aplicar a esse caso o que se viu acima, no sentido de que a lei que pode apresentar tais requisitos é uma lei complementar, não uma lei ordinária, já que, afinal, a imunidade é uma limitação constitucional ao poder de tributar (art. 146, II). Não obstante, a Lei 8.212/91, tratando da organização da seguridade social e do plano de custeio desta, arrola, no seu art. 55, uma série de condições para o gozo da 'isenção'. A referida lei, por ser ordinária, não poderia impor requisitos diversos dos previstos no Código Tributário Nacional, que é lei complementar. O dispositivo foi revogado, mas o tema não perde atualidade. Nesse sentido, a Lei 12.101, de 2009 voltou a arrolar uma série de requisitos para o gozo da imunidade, que ultrapassam os previstos pelo Código Tributário Nacional. Independentemente da razoabilidade, ou não, daquele dispositivo, importa ver que a lei ordinária não é instrumento adequado para regulamentar uma imunidade conferida constitucionalmente" (Direito Tributário. São Paulo: Editora Saraiva, 2011, p. 401-402)

${ }^{27}$ A título de exemplo, citamos a $\mathrm{AC} \mathrm{n}^{\mathrm{o}}$ 2008.83.00014414-8, TRF da $5^{\mathrm{a}}$ Região, $1^{\mathrm{a}}$ Turma, Rel. Des. Fed. Frederico Pinto de Azevedo, DJ-e de 01/10/2010; AMS nº 2006.61.00024424-0, TRF da $3^{\mathrm{a}}$ Região, $3^{\mathrm{a}}$ Turma, Rel. Juíza Eliana Marcelo, DJ-e de 19/11/2010.
} 
lei complementar, a jurisprudência pátria, até o momento, possui entendimento diametralmente oposto - apesar de entender que a lei complementar se aplica à fruição às imunidades condicionadas relacionadas aos impostos. Nesse ponto, dá-se a justificativa da elaboração do presente trabalho científico e sua atualidade.

Dito isso, pretende-se, por meio do presente trabalho científico, discutir quais são os critérios e requisitos a serem preenchidos e observados pelas entidades beneficentes de assistência social, para fins de fruição do gozo da imunidade tributária.

Para tanto, inicialmente, analisar-se-á a Constituição Federal de 1988 e a discriminação da competência tributária legislativa de cada ente tributante. Neste primeiro capítulo também serão apontadas as "limitações constitucionais ao poder de tributar", normas jurídicas que, assim como as instituidoras da competência tributária de cada ente tributante, também teriam o condão de forjar o campo de atuação outorgado pelo legislador constituinte à União, Estados, Distrito Federal e Municípios. Neste ponto, far-se-á uma breve análise acerca das semelhanças e distinções entre imunidades tributárias e princípios constitucionais tributários aplicáveis a elas.

Posteriormente, o presente trabalho acadêmico analisará o conceito dado pela doutrina ao instituto da imunidade tributária e trará o conceito de imunidade tributária construído pelo autor deste trabalho acadêmico; as distinções entre imunidade, isenção e não incidência; se a imunidade tributária constitui-se em um valor ou limite objetivo; a relação entre imunidade tributária e cláusula pétrea ${ }^{28}$ (ou seja, se a figura da imunidade tributária pode ser objeto de limitação ou exclusão por intermédio de Emenda Constitucional ou se o Constituinte originário erigiu-as à condição de cláusulas impassíveis de qualquer espécie de alteração senão mediante a edição de uma nova Carta Constitucional); e a intricada relação entre imunidade tributária e livre concorrência (significando a possibilidade de a existência de limite ou direito de não sujeição à tributação de determinados tributos ser inabalável e intransponível). Nesse capítulo serão avaliados, ainda, os métodos interpretativos das normas de imunidade tributária e o posicionamento do Supremo Tribunal Federal acerca dessa questão. Será que o Supremo Tribunal Federal mantém uma coerência interpretativa em relação às figuras imunitórias? Isso será verificado neste capítulo.

\footnotetext{
28 “Art. 60. A Constituição poderá ser emendada mediante proposta: [...]

$\S 4^{\circ}$ - Não será objeto de deliberação a proposta de emenda tendente a abolir:

I - a forma federativa de Estado;

II - o voto direto, secreto, universal e periódico;

III - a separação dos Poderes;

IV - os direitos e garantias individuais." 
Prosseguindo em nosso estudo acadêmico, trataremos da questão da classificação das imunidades tributárias entre condicionadas e incondicionadas ${ }^{29}$, e as pessoas, coisas ou situações que se enquadram em cada uma das hipóteses de imunidades tributárias descritas na Carta Magna de 1988.

Este estudo será seguido pelo exame da Seguridade Social, a qual nos termos do artigo 194, caput, da Constituição Federal de $1988^{30}$, é composta pelos pilares saúde, previdência e assistência social. Ademais, estudar-se-á o que a Constituição Federal de 1998 convencionou denominar de "assistência social", e se a abrangência dada pelo legislador constituinte é a mesma da dada pelo Supremo Tribunal Federal. Estudar-se-ão, outrossim, os traços característicos das entidades de assistência social, sem fins lucrativos, e suas diferenças em relação às entidades beneficentes de assistência social e às entidades filantrópicas. Serão analisados, ainda, os requisitos a serem preenchidos pelas entidades a fim de que possam ser caracterizadas como "beneficentes de assistência social".

Posteriormente, será analisado o campo de atuação da norma imunitória contida no artigo 150, inciso VI, alínea “c”, da Constituição Federal de 1988, mormente no que diz respeito às entidades beneficentes de assistência social. Esse capítulo terá ainda por objetivo investigar a amplitude da expressão "patrimônio, rendas e serviços relacionadas com as finalidades essenciais", contida no $\S 4^{\circ}$ do artigo 150 da atual Carta Magna. Ademais, adentrar-se-á na discussão acerca do instrumento normativo adequado para regular a imunidade tributária aos impostos das entidades beneficentes de assistência social: se lei ordinária ou complementar. Em seguida, far-se-á um cotejo analítico dos requisitos contidos nos incisos I, II e III, artigo 14, do Código Tributário Nacional ${ }^{31}$, o qual trata dos requisitos a serem preenchidos pelas entidades beneficentes de assistência social, para fins de fruição da imunidade tributária aos impostos.

29 É importante mencionar que o presente estudo somente classificará as imunidades tributárias em condicionadas e incondicionadas, na medida em que todos os esforços serão envidados na tentativa de analisar as imunidades tributárias das entidades beneficentes de assistência social, as quais se enquadram no conceito de imunidades ditas condicionadas.

30 “Art. 194. A seguridade social compreende um conjunto integrado de ações de iniciativa dos Poderes Públicos e da sociedade, destinadas a assegurar os direitos relativos à saúde, à previdência e à assistência social."

31 “Art. 14. O disposto na alínea c do inciso IV do artigo $9^{\circ}$ é subordinado à observância dos seguintes requisitos pelas entidades nele referidas:

I - não distribuírem qualquer parcela de seu patrimônio ou de suas rendas, a qualquer título;

II - aplicarem integralmente, no País, os seus recursos na manutenção dos seus objetivos institucionais;

III - manterem escrituração de suas receitas e despesas em livros revestidos de formalidades capazes de assegurar sua exatidão.” 
Por fim, mas não menos importante, pretende-se apreciar o campo específico de atuação das imunidades tributárias às contribuições sociais destinadas à seguridade social das entidades beneficentes de assistência social. Inicialmente, far-se-á a análise da figura das contribuições no ordenamento jurídico pátrio após a edição da Constituição Federal de 1988, verificando suas características essenciais e a sua natureza jurídica. Em tal contexto, será objeto de estudo sua condição ou não de espécie tributária autônoma. Dando prosseguimento, trataremos da impropriedade utilizada pelo legislador constituinte ao aduzir que as entidades beneficentes de assistência social são "isentas" e não "imunes" às contribuições sociais destinadas à seguridade social.

Outros pontos que também serão suscitados neste capítulo dizem respeito à possibilidade de a legislação ordinária (mais precisamente os artigos 55, da revogada Lei $\mathrm{n}^{\circ}$ 8.212, de 21 de julho de 1991 e o artigo 29, da Lei $n^{\circ} 12.101$, de 30 de novembro de 2009) estabelecer pressupostos outros, além dos contidos no artigo 14 do Código Tributário Nacional, para fins de gozo da imunidade tributária às contribuições sociais destinadas à seguridade social das entidades beneficentes de assistência social.

É importante mencionar que, face à amplitude do tema, o presente estudo não teve o condão nem a pretensão de esgotá-lo, mas tão somente abordar as questões mais relevantes, conexas e importantes ao assunto das imunidades tributárias às contribuições sociais destinadas à seguridade social das entidades beneficentes de assistência social. Sobre tal temática, não obstante orbitar o ordenamento jurídico pátrio desde a promulgação da Constituição Federal de 1988, não há uníssono na doutrina e, especialmente, na jurisprudência construída ao longo dos anos, seja por parte dos órgãos inferiores, seja pelo próprio Supremo Tribunal, órgão máximo do Poder Judiciário, competente para analisar e decidir os motes ligados à imunidade tributária; figura eminentemente constitucional. 


\section{CAPÍTULO I - SISTEMA CONSTITUCIONAL TRIBUTÁRIO BRASILEIRO}

\subsection{A discriminação das competências tributárias dos entes políticos - o Sistema}

Constitucional Tributário Brasileiro

A escolha por parte do legislador constitucional da rigidez ou não do texto constitucional influencia sobremaneira o leque de atuação e abrangência das leis infraconstitucionais. Por um lado, se a Constituição for extremamente rígida, o legislador infraconstitucional não terá muita flexibilidade de atuação, pois terá de seguir à risca os mandamentos e caminhos constitucionais que lhe foram traçados sob pena de inconstitucionalidade. Por outro lado, se a Constituição for sintética e genérica, o legislador infraconstitucional terá maiores condições de atuação. Em suma, quanto maior for a liberdade do legislador infraconstitucional, maior será seu campo de amplitude de atuação.

Se o legislador constitucional optar pelo modelo flexível, basta incluir no texto constitucional que a instituição dos tributos possui como finalidade tão somente custear as necessidades do Estado mediante a observância de uma pequena gama de princípios gerais, tais como o da legalidade e o da igualdade, por exemplo. Feita essa opção, cumprirá ao legislador infraconstitucional traçar todas as linhas mestras para a instituição de determinado e específico tributo. No entanto, se o legislador constitucional optar pelo modelo mais rígido, inflexível, terá ele de dispor sobre uma gama infindável de princípios e ditames a serem necessariamente observados e respeitados pelo legislador infraconstitucional.

O legislador constituinte de 1988 optou pelo modelo rígido.

Ao proferir aula magna, no Superior Tribunal de Justiça, em junho de 1992, Geraldo Ataliba comparou a rigidez do Sistema Constitucional Tributário às ordens emanadas pelo General tendo como destinatário o Major, dando conta dos específicos exercícios a serem realizados, bem como as vestimentas a serem usadas pelos soldados para o desfile em comemoração ao Dia da Independência do Brasil (7 de setembro):

Vejam bem: as tropas são iguais e os comandantes são do mesmo nível hierárquico. A ordem, a finalidade última é a mesma. "Prepara a tropa para o dia 7 de setembro". Entretanto, a liberdade que eu, oficial comandante, tenho para preparar esta tropa para o dia 7 de setembro é a mais ampla, desde que eu dê as duas horas de ginástica por dia, porque essa foi a ordem do General. Quanto ao outro Major, a finalidade dele é a mesma; só que ele não tem 
liberdade nenhuma porque, examinando o rol de instruções que o General lhe deu, não tem opção, não tem o que decidir livremente. Já está sabendo quantas horas de ginástica, quantas de natação, qual o uniforme que deve usar, etc. A situação é a mesma do legislador europeu. As constituições europeias dizem: "Legislador, tribute! Imponha os tributos! Faça a lei tributária! Obedeça a legalidade! Observe a igualdade! Ponto!"

Ali na outra sala está o Brasil. O constituinte, que é o General, diz "Legislador, faça a lei tributária! Mas deve fazer com tais e quais limitações, com tais condicionamentos, regras, limites; este legislador só pode fazer isso, aquele só pode fazer aquilo etc." 32

Conforme se verifica pela análise dos ensinamentos de Geraldo Ataliba transcritos acima, o legislador constitucional engessou de tal forma o espectro de atuação do legislador infraconstitucional que o último, quando da instituição dos tributos de sua competência, deverá seguir à risca àquilo determinado pela Constituição Federal sob pena de inconstitucionalidade.

Dessa forma, estabelecido que o legislador infraconstitucional não poderá inovar no quesito instituição de tributo, razão pela qual a Constituição Federal de 1988 pode ser "definida como uma verdadeira Carta de Competências"33, cumpre-nos conceituar “competência tributária".

Em linhas gerais, entende-se por competência tributária a aptidão para, em abstrato, instituir tributos ${ }^{34}$.

De acordo com o posicionamento de Roque Antonio Carraza somente as pessoas políticas possuem competência tributária, porquanto só elas possuem Poder Legislativo com representação própria. São suas as seguintes palavras:

\footnotetext{
${ }^{32}$ ATALIBA, Geraldo. Limitações constitucionais ao poder de tributar. In: Revista de Direito Tributário n. 62 , São Paulo: Malheiros, 1992. p. 113.

${ }^{33}$ BARRETO, Paulo Ayres. Contribuições: regime jurídico, destinação e controle. 2. ed. São Paulo: Noeses, 2011. p. 28.

${ }^{34}$ Cabe, aqui, mencionar que fazemos alusão somente à competência tributária legislativa, na medida em que, tal qual afirmado por Paulo de Barros Carvalho, em sua obra Curso de Direito Tributário, a expressão "competência tributária" possui "várias proporções semânticas": "Mas essa é apenas uma entre as várias proporções semânticas com que a expressão se manifesta, justificando o asserto de Becker segundo o qual $o$ jurista é o semântico da linguagem do direito. Não podemos deixar de considerar que têm, igualmente, competência tributária o Presidente da República, ao expedir um decreto sobre IR, ou seu ministro ao editar a correspondente instrução interministerial; o magistrado e o tribunal que vão julgar a causa; o agente da administração encarregado de lavrar o ato de lançamento, bem como os órgãos que irão participar da discussão administrativa instaurada com a peça impugnatória; aquele sujeito de direito privado habilitado a receber o pagamento de tributo (bancos, por exemplo); ou mesmo o particular que, por força de lei, está investido na condição de praticar a sequência procedimental que culminará com a produção de norma jurídica tributária, individual e concreta (casos de IPI, ICMS, ISS etc). Todos eles operam revestidos de competência tributária, o que mostra a multiplicidade de traços significativos que a locução está pronta para exibir. Não haveria por que adjudicar o privilégio a qualquer delas, em detrimento das demais. Como sugeriram expoentes do Neopositivismo Lógico, em situações desse jaez cabe-nos tão somente especificar o sentido em que estamos empregando a dicção, para afastar, por esse modo, as possíveis ambiguidades" (Curso de Direito Tributário Brasileiro. 26. ed. São Paulo: Saraiva, 2014. p. 270).
} 
Sublinhamos que, neste passo, estamos aludindo à criação de tributos, tarefa exclusivamente legislativa, e não à sua mera arrecadação, mister que se relaciona com o exercício da função administrativa. Conforme já consignamos, o exercício da competência tributária é uma das manifestações do exercício da função legislativa, que flui da Constituição. Em suma, criar tributos é legislar; arrecadá-los, administrar. ${ }^{35}$

Segundo Paulo de Barros Carvalho, competência tributária é a aptidão de que são dotadas as pessoas políticas para legislar para a produção de normas jurídicas sobre tributos.

Dessa forma, em decorrência de a competência tributária provir da função legislativa e ser matéria de ordem constitucional, somente a Constituição pode traçar as competências de cada um dos entes federativos.

Os entes, por sua vez e por intermédio de lei, seja ela ordinária ou complementar, nos casos em que a Constituição Federal assim o exigir ${ }^{36}$ visando à criação dos tributos de suas competências, terão de traçar todos os critérios da regra-matriz de incidência tributária, independentemente dos critérios material, espacial, temporal, quantitativo (base de cálculo e alíquota) e dos sujeitos da relação (ativo e passivo).

A questão da competência tributária difere sobremaneira nos sistemas unitário e federal. Nos países que adotam o Sistema Unitário, somente um ente possui competência para instituir tributos. Como exemplo de Estado Unitário pode-se citar Portugal. De acordo com a Constituição portuguesa, somente a Assembleia da República possui competência para legislar sobre a criação de impostos, sistema fiscal, regime geral das taxas e demais contribuições financeiras ${ }^{37}$.

Trata-se, portanto, nas palavras de Diogo Leite Campos e Mônica Campos, de "poder de tributar com carácter originário"38 " "poder" esse que não necessita de qualquer espécie de

\footnotetext{
${ }^{35}$ CARRAZA, Roque Antonio. Curso de Direito Constitucional Tributário. 29. ed. São Paulo: Malheiros, 2013. p. 576-577.

${ }^{36}$ De acordo com a Constituição Federal de 1988, mais precisamente seus artigos 154, inciso I, e artigo 195, $\S 4^{\circ}$, a União Federal poderá instituir, mediante lei complementar, impostos não previstos no artigo 153, desde que os mesmos sejam não-cumulativos e não tenham hipótese de incidência ou base de cálculo próprios dos impostos descritos na Constituição Federal; ou, ainda, contribuições sociais destinadas à seguridade social, desde que respeitadas as restrições contidas no artigo 154 , I, da Constituição.

${ }^{37}$ É o que prescreve o artigo 165, 1, i, da Carta Política Portuguesa, aprovada pela Assembleia Constituinte em 02 de abril de 1976:

"Art. 165. (Reserva relativa de competência legislativa:

1. É da exclusiva competência da Assembleia da República legislar sobre as seguintes matérias, salvo autorização ao Governo:

[...]

i) Criação de impostos e sistema fiscal e regime geral das taxas e demais contribuições."

${ }^{38}$ CAMPOS, Diogo Leite; CAMPOS, Mônica Horta Neves. Direito Tributário. 2. ed. Coimbra: Almedina, 2000. p. 198.
} 
autorização por parte de órgão algum ou, até mesmo, de lei alguma, de modo que ele pode ser considerado como autoexecutável.

Apesar de o "poder de tributar" concentrar-se nas mãos da Assembleia da República, a Carta Magna portuguesa estabelece a possibilidade de o Governo, as Regiões Autônomas e as Autarquias Legais legislarem e instituírem tributos, desde que respeitado o princípio da reserva legal. Trata-se, nesse caso, de poder de tributar com "caracter derivado", nas palavras de Diogo Leite Campos e Mônica Campos ${ }^{39}$.

Dessa forma, apesar de Portugal adotar o Sistema Unitário, a própria Constituição permite que os demais órgãos, além da Assembleia da República, possam instituir tributos, desde que respeitado o primado da legalidade.

Diferentemente do que ocorre em relação aos países que adotam o Sistema Unitário, os países que encampam o Sistema Federativo, por meio das respectivas Constituições Federais, delimitam a competência de cada um de seus entes. É justamente isso que ocorre com o Sistema Constitucional Tributário Brasileiro.

Isso porque a Constituição Federal de 1988 traçou, de forma minudente, o campo de atuação de cada um dos entes políticos (União, Estados, Distrito Federal e Municípios) de modo que cada um opere dentro da sua faixa de competência constitucionalmente delimitada.

Nos termos expostos por Heleno Taveira Torres ${ }^{40}$, a União, os Estados e os Municípios pátrios receberam poder originário da Constituição Federal de 1988 para instituir o próprio sistema tributário. De fato, os municípios brasileiros receberam originariamente competência tributária direta da Constituição. Isso pode ser facilmente constatado pela análise do artigo 30 dessa Constituição Federal, que assim determina:

Art. 30. Compete aos Municípios: I - legislar sobre assuntos de interesse local; II - suplementar a legislação federal e a estadual no que couber; III instituir e arrecadar os tributos de sua competência, bem como aplicar suas rendas, sem prejuízo da obrigatoriedade de prestar contas e publicar balancetes nos prazos fixados em lei; IV - criar, organizar e suprimir distritos, observada a legislação estadual; V - organizar e prestar, diretamente ou sob regime de concessão ou permissão, os serviços públicos de interesse local, incluído o de transporte coletivo, que tem caráter essencial; VI - manter, com a cooperação técnica e financeira da União e do Estado, programas de educação infantil e de ensino fundamental; VII prestar, com a cooperação técnica e financeira da União e do Estado, serviços de atendimento à saúde da população; VIII - promover, no que couber, adequado ordenamento territorial, mediante planejamento e controle

\footnotetext{
${ }^{39}$ CAMPOS; CAMPOS, op. cit., p. 198.

40 Direito Constitucional Tributário e Segurança Jurídica: Metódica da Segurança Jurídica do Sistema Constitucional Tributário. São Paulo: Revista dos Tribunais, 2011. p. 312.
} 
do uso, do parcelamento e da ocupação do solo urbano; e IX - promover a proteção do patrimônio histórico-cultural local, observada a legislação e a ação fiscalizadora federal e estadual.

A delimitação minuciosa da competência de cada ente tributante decorre da rigidez do Sistema Constitucional Tributário. Segundo Geraldo Ataliba, "nenhum outro sistema constitucional tributário do mundo reveste tal característica." 41

Ainda segundo os ensinamentos desse renomado doutrinador ${ }^{42}$, a rigidez do Sistema Tributário Brasileiro foi inaugurada na Constituição de 1934, que conferiu competências privativas à União, aos Estados e aos Municípios e estabeleceu, ainda que de forma fragilizada, a competência residual. Essa característica de rigidez e inflexibilidade na discriminação das competências tributárias permaneceu nas Constituições posteriores e encontra-se presente na Carta Magna de 1988.

A esse propósito, vejam-se as considerações de Paulo Ayres Barreto:

O sistema passível de ser erigido a partir da Constituição de 88 dista de ser sintético ou genérico. Não se caracteriza pela plasticidade. Ao revés, nossa Constituição é rígida. Cuida de talhar, minudentemente, diversos subsistemas, dentre eles o tributário. Com efeito, não há sistema constitucional que se assemelhe ao nosso, na extensividade no trato da matéria tributária. Tal opção legislativa, já de longa tradição no Brasil, produz relevantes efeitos jurídicos. Gostemos ou não dela, é forçoso reconhecer que foi o caminho escolhido pelo legislador constituinte. Em consequência, a aproximação que o intérprete haverá de fazer ao direito posto terá não apenas como ponto de partida a Constituição Federal; mais do que isso, exigir-se-á um longo e espinhoso trabalho exegético, realizado exclusivamente nesse plano constitucional, para então se perquirir sobre o conteúdo dos comandos normativos infraconstitucionais. ${ }^{43}$

O sistema constitucional tributário pátrio é tão rígido que o próprio legislador constitucional tratou de repartir as competências tributárias dos entes políticos, classificar os tributos, estabelecer alguns critérios da regra-matriz de incidência ${ }^{44}$, estabelecer os direitos

\footnotetext{
${ }^{41}$ Sistema Constitucional Tributário. São Paulo: Revista dos Tribunais, 1968. p. 22.

${ }^{42}$ ATALIBA, op. cit., pp. 22-88.

${ }^{43}$ BARRETO, Paulo Ayres. Contribuições: regime jurídico, destinação e controle. São Paulo: Noeses, $2011, \mathrm{p}$. 28.

${ }^{44}$ Para Carraza, no entanto, a Constituição Federal estabeleceu a norma padrão de incidência (arquétipo genérico ou regra-matriz) de cada um dos tributos nela elencados. Segundo esse autor, a Carta Magna apontou a "hipótese de incidência possível, o sujeito ativo possível, o sujeito passivo possível, a base de cálculo possível e a alíquota possível, das várias espécies e subespécies de tributos. Em síntese, o legislador, ao exercitar a competência tributária, deverá ser fiel à norma-padrão do tributo, pré-traçada na Constituição" (CARRAZA, Roque Antonio. Curso de Direito Constitucional Tributário. São Paulo: Malheiros, 29 ed., 2013. p. 306.).
} 
fundamentais do contribuinte, fixar conceitos, repartir a receita tributária e vincular o produto arrecadado.

O Capítulo I do Título VI da Constituição Federal de 1988, entre os artigos 150 e 162, trata "Do Sistema Tributário Nacional". Nele é possível verificar, dentre outras atribuições, as competências de cada ente político. Isso quer dizer que, nesse capítulo, o legislador constitucional tratou de estabelecer o campo de atuação da União, dos Estados, do Distrito Federal e dos Municípios, uma vez que tais entes só poderão instituir os tributos delineados no capítulo em questão e desde que respeitada a autonomia econômico-financeira dos Estados e Municípios (com exceção feita em relação à competência residual da União para instituir impostos extraordinários).

Mesmo considerando que a Constituição Federal de 1988 trata do Sistema Constitucional Tributário em capítulo específico (Capítulo I, do Título VI), é forçoso reconhecer a existência de inúmeros outros dispositivos contidos em tal texto legal que também dispõem acerca do conjunto de normas que visam a regulação das relações jurídicas entre Fisco e contribuintes. Como exemplo dessas normas jurídicas que não são tratadas no Capítulo da Constituição Federal destinado ao "Sistema Tributário Nacional", mas que estabelecem critérios a serem observados pelos entes públicos para a instituição dos tributos de sua competência tributária, pode-se citar o artigo 195, da Constituição Federal de $1988^{45}$.Consoante será melhor delineado a seguir, o artigo em questão trata da possibilidade de a União, e tão somente ela, instituir contribuições sociais destinadas à seguridade social.

\footnotetext{
45 “Art. 195. A seguridade social será financiada por toda a sociedade, de forma direta e indireta, nos termos da lei, mediante recursos provenientes dos orçamentos da União, dos Estados, do Distrito Federal e dos Municípios, e das seguintes contribuições sociais: (Vide Emenda Constitucional no 20, de 1998)

I - do empregador, da empresa e da entidade a ela equiparada na forma da lei, incidentes sobre: (Redação dada pela Emenda Constitucional no 20, de 1998)

a) a folha de salários e demais rendimentos do trabalho pagos ou creditados, a qualquer título, à pessoa física que lhe preste serviço, mesmo sem vínculo empregatício; (Incluído pela Emenda Constitucional no 20, de 1998)

b) a receita ou o faturamento; (Incluído pela Emenda Constitucional $n^{\circ} 20$, de 1998)

c) o lucro; (Incluído pela Emenda Constitucional n 20 , de 1998)

II - do trabalhador e dos demais segurados da previdência social, não incidindo contribuição sobre aposentadoria e pensão concedidas pelo regime geral de previdência social de que trata o art. 201; (Redação dada pela Emenda Constitucional $\mathrm{n}^{\circ}$ 20, de 1998)

III - sobre a receita de concursos de prognósticos.

IV - do importador de bens ou serviços do exterior, ou de quem a lei a ele equiparar. (Incluído pela Emenda Constitucional $n^{\circ} 42$, de 19.12.2003)

$\S 1^{\circ}$ - As receitas dos Estados, do Distrito Federal e dos Municípios destinadas à seguridade social constarão dos respectivos orçamentos, não integrando o orçamento da União.

$\S 2^{\circ}$ - A proposta de orçamento da seguridade social será elaborada de forma integrada pelos órgãos responsáveis pela saúde, previdência social e assistência social, tendo em vista as metas e prioridades estabelecidas na lei de diretrizes orçamentárias, assegurada a cada área a gestão de seus recursos.
} 
Visando a criação de contribuições sociais destinadas à seguridade social, o legislador infraconstitucional federal deverá limitar-se às hipóteses descritas nos incisos I, II, III e IV do artigo 195, que são:

1. do empregador, da empresa ou da entidade a ela equiparada, incidente sobre:
a. a folha de salários;
b. a receita ou faturamento; ou
c. lucro;

2. do trabalhador e demais segurados da previdência social;

3. sobre a receita de concursos de prognósticos;

4. ou do importador de bens ou serviços.

Afora essas hipóteses, a União não terá competência, no sentido de aptidão, para instituir contribuições sociais destinadas à seguridade social.

$\S 3^{\circ}$ - A pessoa jurídica em débito com o sistema da seguridade social, como estabelecido em lei, não poderá contratar com o Poder Público nem dele receber benefícios ou incentivos fiscais ou creditícios. (Vide Medida Provisória $\mathrm{n}^{\circ}$ 526, de 2011) (Vide Lei $\mathrm{n}^{\mathrm{0}}$ 12.453, de 2011)

$\S 4^{\circ}$ - A lei poderá instituir outras fontes destinadas a garantir a manutenção ou expansão da seguridade social, obedecido o disposto no art. 154, I.

$\S 5^{\circ}$ - Nenhum benefício ou serviço da seguridade social poderá ser criado, majorado ou estendido sem a correspondente fonte de custeio total.

$\S 6^{\circ}$ - As contribuições sociais de que trata este artigo só poderão ser exigidas após decorridos noventa dias da data da publicação da lei que as houver instituído ou modificado, não se lhes aplicando o disposto no art. 150 , III, "b".

$\S 7^{\circ}$ - São isentas de contribuição para a seguridade social as entidades beneficentes de assistência social que atendam às exigências estabelecidas em lei.

$\S 8^{\circ} \mathrm{O}$ produtor, o parceiro, o meeiro e o arrendatário rurais e o pescador artesanal, bem como os respectivos cônjuges, que exerçam suas atividades em regime de economia familiar, sem empregados permanentes, contribuirão para a seguridade social mediante a aplicação de uma alíquota sobre o resultado da comercialização da produção e farão jus aos benefícios nos termos da lei. (Redação dada pela Emenda Constitucional $n^{\circ} 20$, de 1998)

$\S 9^{\circ}$ As contribuições sociais previstas no inciso I do caput deste artigo poderão ter alíquotas ou bases de cálculo diferenciadas, em razão da atividade econômica, da utilização intensiva de mão-deobra, do porte da empresa ou da condição estrutural do mercado de trabalho. (Redação dada pela Emenda Constitucional no 47, de 2005)

$\S 10$. A lei definirá os critérios de transferência de recursos para o sistema único de saúde e ações de assistência social da União para os Estados, o Distrito Federal e os Municípios, e dos Estados para os Municípios, observada a respectiva contrapartida de recursos. (Incluído pela Emenda Constitucional no 20, de 1998)

$\S 11$. É vedada a concessão de remissão ou anistia das contribuições sociais de que tratam os incisos I, a, e II deste artigo, para débitos em montante superior ao fixado em lei complementar. (Incluído pela Emenda Constitucional $n^{\circ} 20$, de 1998)

$\S 12$. A lei definirá os setores de atividade econômica para os quais as contribuições incidentes na forma dos incisos I, b; e IV do caput, serão não-cumulativas. (Incluído pela Emenda Constitucional n ${ }^{\circ} 42$, de 19.12.2003)

$\S 13$. Aplica-se o disposto no $\S 12$ inclusive na hipótese de substituição gradual, total ou parcial, da contribuição incidente na forma do inciso I, a, pela incidente sobre a receita ou o faturamento. (Incluído pela Emenda Constitucional n 42, de 19.12.2003)" 
É justamente por esse motivo que o Plenário do Supremo Tribunal Federal, em decisão proferida nos autos do Recurso Extraordinário ${ }^{\circ}$ 595.838, erigido à condição de repercussão geral, decidiu pela inconstitucionalidade do artigo 22, inciso IV, da Lei ${ }^{\circ}$ 8.212, de 24 de julho de 1991, que trata da incidência de contribuição previdenciária sobre o valor bruto da nota fiscal ou fatura de prestação de serviços por parte de cooperativas de trabalho ${ }^{46}$.

Nessa oportunidade, os Ministros do Supremo Tribunal Federal, à unanimidade de votos, entenderam que, dentre outros motivos, a tributação via contribuição previdenciária dos serviços prestados por cooperativas de trabalho não possui arrimo constitucional. Uma vez que a Carta Magna de 1988 somente autoriza a instituição dessa espécie tributária sobre a folha de pagamentos, a receita ou o faturamento, ou sobre o lucro, de modo que a instituição de contribuição previdenciária sobre o valor bruto da nota fiscal ou da fatura relacionadas à prestação de serviços por parte de cooperativas refoge às hipóteses constitucionalmente permitidas para a instituição de tais tributos.

Definida e delimitada a competência tributária pelo legislador constitucional, possui o legislador infraconstitucional a faculdade de exercitá-la ou não, com exceção feita ao ICMS, na medida em que os Estados e o Distrito Federal não podem abrir mão da competência para instituir esse imposto.

Nada obstante possuir o legislador infraconstitucional competência para instituir os tributos descritos na Constituição Federal de 1988, ele deverá, quando exercer essa faculdade, observar limites, parâmetros e balizas, que não são poucos, estabelecidos no altiplano constitucional, sob pena de inconstitucionalidade.

Um desses balizamentos é justamente a imunidade tributária, a qual, por constituir-se em norma de estrutura ${ }^{47}$, auxilia na designação do campo de abrangência do legislador infraconstitucional, delimitando ainda mais seu campo de atuação. É sobre essa norma de

\footnotetext{
46 “Art. 22. A contribuição a cargo da empresa, destinada à Seguridade Social, além do disposto no art. 23, é de: [...]

IV - quinze por cento sobre o valor bruto da nota fiscal ou fatura de prestação de serviços, relativamente a serviços que lhe são prestados por cooperados por intermédio de cooperativas de trabalho. (Incluído pela Lei $\mathrm{n}^{\circ}$ 9.876, de 1999)."

${ }^{47}$ As normas de comportamento se prestam a regular a conduta intersubjetiva; já as normas de estrutura possuem por objeto regular a produção normativa, ou seja, a produção de outras normas jurídicas. Acerca dessa diferenciação, Paulo Ayres Barreto assim se manifesta: “As normas jurídicas podem ser classificadas em normas de estrutura e normas de conduta, com base no objeto imediato da sua regulação. $\mathrm{O}$ critério definidor da classificação proposta é objeto imediato regulado pela norma jurídica. As de comportamento regulam diretamente a conduta das pessoas, nas relações de intersubjetividade. As de estrutura têm como objeto imediato os modos de criação, modificação e expulsão das normas jurídicas. [...]" (BARRETO, Paulo Ayres. Contribuições: regime jurídico, destinação e controle. 2. ed. São Paulo: Editora Noeses, 2011. p. 7.).
} 
estrutura auxiliadora da delimitação da competência tributária dos entes políticos que o presente trabalho se debruçará.

\subsection{Limitações Constitucionais ao Poder de Tributar}

De acordo com a Constituição Federal de 1988, mais precisamente nos termos da Seção II do Capítulo I do Título VI, os artigos $150^{48}, 151^{49}$ e $152^{50}$ tratam das "Limitações Constitucionais ao Poder de Tributar".

48 “Art. 150. Sem prejuízo de outras garantias asseguradas ao contribuinte, é vedado à União, aos Estados, ao Distrito Federal e aos Municípios:

I - exigir ou aumentar tributo sem lei que o estabeleça;

II - instituir tratamento desigual entre contribuintes que se encontrem em situação equivalente, proibida qualquer distinção em razão de ocupação profissional ou função por eles exercida, independentemente da denominação jurídica dos rendimentos, títulos ou direitos;

III - cobrar tributos:

a) em relação a fatos geradores ocorridos antes do início da vigência da lei que os houver instituído ou aumentado;

b) no mesmo exercício financeiro em que haja sido publicada a lei que os instituiu ou aumentou;

c) antes de decorridos noventa dias da data em que haja sido publicada a lei que os instituiu ou aumentou, observado o disposto na alínea b;

IV - utilizar tributo com efeito de confisco;

V - estabelecer limitações ao tráfego de pessoas ou bens, por meio de tributos interestaduais ou intermunicipais, ressalvada a cobrança de pedágio pela utilização de vias conservadas pelo Poder Público;

VI - instituir impostos sobre:

a) patrimônio, renda ou serviços, uns dos outros;

b) templos de qualquer culto;

c) patrimônio, renda ou serviços dos partidos políticos, inclusive suas fundações, das entidades sindicais dos trabalhadores, das instituições de educação e de assistência social, sem fins lucrativos, atendidos os requisitos da lei;

d) livros, jornais, periódicos e o papel destinado a sua impressão.

e) fonogramas e videofonogramas musicais produzidos no Brasil contendo obras musicais ou literomusicais de autores brasileiros e/ou obras em geral interpretadas por artistas brasileiros bem como os suportes materiais ou arquivos digitais que os contenham, salvo na etapa de replicação industrial de mídias ópticas de leitura a laser.

$\S 1^{\circ}$ A vedação do inciso III, b, não se aplica aos tributos previstos nos arts. 148, I, 153, I, II, IV e V; e 154, II; e a vedação do inciso III, c, não se aplica aos tributos previstos nos arts. 148, I, 153, I, II, III e V; e 154, II, nem à fixação da base de cálculo dos impostos previstos nos arts. 155, III, e 156, I.

$\S 2^{\circ}$ - A vedação do inciso VI, "a", é extensiva às autarquias e às fundações instituídas e mantidas pelo Poder Público, no que se refere ao patrimônio, à renda e aos serviços, vinculados a suas finalidades essenciais ou às delas decorrentes.

$\S 3^{\circ}$ - As vedações do inciso VI, "a", e do parágrafo anterior não se aplicam ao patrimônio, à renda e aos serviços, relacionados com exploração de atividades econômicas regidas pelas normas aplicáveis a empreendimentos privados, ou em que haja contraprestação ou pagamento de preços ou tarifas pelo usuário, nem exonera o promitente comprador da obrigação de pagar imposto relativamente ao bem imóvel.

$\S 4^{\circ}$ - As vedações expressas no inciso VI, alíneas "b" e "c", compreendem somente o patrimônio, a renda e os serviços, relacionados com as finalidades essenciais das entidades nelas mencionadas.

$\S 5^{\circ}$ - A lei determinará medidas para que os consumidores sejam esclarecidos acerca dos impostos que incidam sobre mercadorias e serviços.

$\S$ 6. $^{\circ}$ Qualquer subsídio ou isenção, redução de base de cálculo, concessão de crédito presumido, anistia ou remissão, relativos a impostos, taxas ou contribuições, só poderá ser concedido mediante lei específica, federal, estadual ou municipal, que regule exclusivamente as matérias acima enumeradas ou o correspondente tributo ou contribuição, sem prejuízo do disposto no art. $155, \S 2 .^{\circ}, \mathrm{XII}, \mathrm{g}$. 
Esses artigos tratam, basicamente, de dois grandes grupos de "Limitações Constitucionais ao Poder de Tributar": os princípios constitucionais tributários e as imunidades tributárias genéricas.

Assim como aduzido por Paulo de Barros Carvalho ${ }^{51}$, a linguagem do legislador, seja ele constitucional ou infraconstitucional, é marcada por expressões imprecisas vagas ou ambíguas, uma vez que nem todos os integrantes das Casas Legislativas possuem aptidões ou conhecimentos jurídicos, o que é plenamente aceitável e salutar em um Estado Democrático de Direito tal qual o Estado brasileiro.

Por conta disso, não obstante a Carta Magna de 1988 dispor que as "Limitações Constitucionais ao Poder de Tributar" estão contidas somente nos artigos 150 a 152, tal afirmativa não corresponde à realidade, na medida em que o texto constitucional trata dessa figura em outros dispositivos ${ }^{52}$. Como exemplos, podem-se citar o princípio da livre iniciativa contido no artigo 170 , parágrafo único ${ }^{53}$, bem como a imunidade das contribuições sociais destinadas à seguridade social das entidades beneficentes de assistência social a que o artigo 195 faz alusão ${ }^{54}$.

$\S 7 .^{\circ}$ A lei poderá atribuir a sujeito passivo de obrigação tributária a condição de responsável pelo pagamento de imposto ou contribuição, cujo fato gerador deva ocorrer posteriormente, assegurada a imediata e preferencial restituição da quantia paga, caso não se realize o fato gerador presumido."

49 “Art. 151. É vedado à União:

I - instituir tributo que não seja uniforme em todo o território nacional ou que implique distinção ou preferência em relação a Estado, ao Distrito Federal ou a Município, em detrimento de outro, admitida a concessão de incentivos fiscais destinados a promover o equilíbrio do desenvolvimento sócio-econômico entre as diferentes regiões do País;

II - tributar a renda das obrigações da dívida pública dos Estados, do Distrito Federal e dos Municípios, bem como a remuneração e os proventos dos respectivos agentes públicos, em níveis superiores aos que fixar para suas obrigações e para seus agentes;

III - instituir isenções de tributos da competência dos Estados, do Distrito Federal ou dos Municípios."

50 “Art. 152. É vedado aos Estados, ao Distrito Federal e aos Municípios estabelecer diferença tributária entre bens e serviços, de qualquer natureza, em razão de sua procedência ou destino"

${ }^{51}$ CARVALHO, Paulo de Barros. Curso de Direito Tributário. 26. ed. São Paulo: Saraiva, 2014. p. 36-37.

${ }^{52}$ Esse também é o entendimento de Humberto Ávila (Sistema Constitucional Tributário. São Paulo: Editora Saraiva, $5^{\text {a }}$ edição, 2012, p. 163), Sacha Calmon Navarro Coêlho (Curso de Direito Tributário Brasileiro. Rio de Janeiro: Editora Forense, 10 ed., 2009, p. 156) e Luís Eduardo Schoueri (Direito Tributário. São Paulo: Editora Saraiva, $2^{\text {a }}$ edição, 2012, p. 269).

53 “Art. 170. A ordem econômica, fundada na valorização do trabalho humano e na livre iniciativa, tem por fim assegurar a todos existência digna, conforme os ditames da justiça social, observados os seguintes princípios:

Parágrafo único. É assegurado a todos o livre exercício de qualquer atividade econômica, independentemente de autorização de órgãos públicos, salvo nos casos previstos em lei."

54 “Art. 195. A seguridade social será financiada por toda a sociedade, de forma direta e indireta, nos termos da lei, mediante recursos provenientes dos orçamentos da União, dos Estados, do Distrito Federal e dos Municípios, e das seguintes contribuições sociais:

[...] $\S 7^{\circ}$ - São isentas de contribuição para a seguridade social as entidades beneficentes de assistência social que atendam às exigências estabelecidas em lei." 
A Lei Complementar também poderá tratar das "Limitações Constitucionais ao Poder de Tributar". Tal ocorre porque o artigo 146, inciso II, da Constituição Federal ${ }^{55}$ estabelece que uma das funções dessa espécie normativa é justamente a de regular as "Limitações Constitucionais ao Poder de Tributar”. Essa limitação, embora prevista constitucionalmente, está especificada e delimitada fora do texto constitucional. Outro exemplo diz respeito às Resoluções do Senado Federal, as quais estabelecem as alíquotas do ICMS aplicáveis às operações e prestações interestaduais e de exportação ou, ainda, as alíquotas mínimas a serem praticadas pelos Estados nas operações internas ou as alíquotas máximas nas mesmas operações visando a dirimir conflito entre Estados (artigo 155, $\S 2^{\circ}$, incisos IV e V, da Constituição).

Dessa forma, apesar de a própria Constituição Federal mencionar que as "Limitações Constitucionais ao Poder de Tributar" estão contidas somente em seus artigos 150 a 152, tal assertiva não é $100 \%$ verdadeira, de modo que o legislador, ao editar normativos, e o intérprete, ao construir qualquer norma jurídica de cunho tributário, deverão trabalhar não somente os artigos acima aludidos, mas também aos demais contidos no texto constitucional que delimitam o "poder de tributar" dos entes políticos.

Como se não bastasse a imprecisão do legislador constituinte ao aduzir que as “Limitações Constitucionais ao Poder de Tributar" estão albergadas somente nos artigos 150 a 152 da Constituição Federal, houve o cometimento de outro equívoco em relação a essas "limitações”. Trata-se da utilização da expressão "poder tributário".

O "poder tributário" é expressão do "poder político" e consequência do jus imperium do Estado, o qual, por tratar-se de manifestação da soberania estatal, é originalmente ilimitado. Ocorre, no entanto, que, com a ocorrência do constitucionalismo do Estado Democrático de Direito $^{56}$ e a consequente promulgação da Constituição Federal de 1988, o

\footnotetext{
55 “Art. 146. Cabe à lei complementar:

$[\ldots]$

II - regular as limitações constitucionais ao poder de tributar;"

${ }^{56} \mathrm{O}$ constitucionalismo democrático foi a ideologia vitoriosa do século XIX, derrotando diversos projetos alternativos e autoritários que com ele concorreram. Também referido como Estado constitucional ou, na terminologia da Constituição brasileira, como Estado Democrático de Direito, ele é o produto da fusão de duas ideias que tiveram trajetórias históricas diversas, mas que se conjugaram para produzir o modelo ideal contemporâneo: constitucionalismo e democracia. Constitucionalismo significa Estado de direito, poder limitado e respeito aos direitos fundamentais. Democracia, por sua vez, traduz a ideia de soberania popular, governo do povo, vontade da maioria. O constitucionalismo democrático, assim, é uma fórmula política baseada no respeito aos direitos fundamentais e no autogoverno popular. E é, também, um modo de organização social fundado na cooperação de pessoas livres e iguais.
} 
Estado deixou de utilizar a soberania estatal como fundamento do tributo ${ }^{57}$ e passou a repartir as competências entre os entes públicos.

Assim, com a promulgação da Carta Política em 5 de outubro de 1988, não há mais que se falar em "poder de tributar", mas sim em "competência tributária". E é justamente por meio dessa competência tributária que a Constituição atribuiu a cada um dos entes públicos (União, Estados, Distrito Federal e Municípios) uma faixa exclusiva de atuação.

Vejam-se, nesse sentido, as considerações de Roque Antonio Carraza:

No Brasil, por força de uma série de disposições constitucionais, não há falar em poder tributário (incontratável, absoluto), mas, tão somente, em competência tributária (regrada, disciplinada pelo Direito).

De fato, entre nós, a força tributante estatal não atua livremente, mas dentro dos limites do direito positivo. Como veremos em seguida, cada uma das pessoas políticas não possui, em nosso País, poder tributário (manifestação do ius imperium do Estado), mas competência tributária (manifestação da autonomia da pessoa política e, assim, sujeita ao ordenamento jurídicoconstitucional). A competência tributária é determinada pelas normas constitucionais, que, como é pacífico, são de grau superior às de nível legal, que - estas sim - preveem as concretas obrigações tributárias.

Em boa técnica, não se deve dizer que as pessoas políticas têm, no Brasil, poder tributário. Poder tributário tinha a Assembleia Nacional Constituinte, que era soberana. Ela, realmente, tudo podia, inclusive em matéria tributária. A partir do momento, porém, em que foi promulgada a Constituição Federal, o poder tributário retornou ao povo (detentor da soberania). O que passou a existir, em seu lugar, foram as competências tributárias, que a mesma Constituição Federal repartiu entre a União, os Estados-membros, os Municípios e o Distrito Federal ${ }^{58}$.

Por esses motivos e por entender que as imunidades tributárias não atuam como limitadoras da competência tributária ${ }^{59}$, acredita-se que a terminologia mais adequada para a Seção II do Capítulo I do Título VI da Constituição Federal de 1988 seria a de "Delimitações Constitucionais à Competência Tributária", apesar de termos ciência de que a terminologia

\footnotetext{
${ }^{57}$ De acordo com Heleno Taveira Torres, "o pensamento clássico do Estado via na soberania uma propriedade do poder do Estado, pelo qual exercitaria seus poderes em uma espécie de autolimitação, pela sujeição aos próprios deveres e obrigações assumidos em face dos súditos. Nesse modelo, a soberania seria ilimitada, no sentido de que nenhum outro poder teria eficácia para impedir o Estado de modificar sua Constituição, suas próprias leis ou sua ordem jurídica". (TORRES, Heleno Taveira. Direito Constitucional Tributário e Segurança Jurídica: metódica da segurança jurídica do Sistema Constitucional Tributário. São Paulo: Revista dos Tribunais, 2011. p. 307).

${ }^{58}$ CARRAZA, Roque Antonio. Curso de Direito Constitucional Tributário. 29. ed. São Paulo: Malheiros, 2013. p. 574.

59 Tal qual será analisado em tópico específico (item 2.1), não há que se falar que as imunidades tributárias limitam a competência tributária, já que elas, imunidades, não atuam em momento posterior à demarcação da competência tributária, mas sim em momento lógico idêntico. Para que haja a correta demarcação da sua competência, o ente tributante terá de editar normas que levem em consideração as normas jurídicas ditas positivas (princípios) e as negativas (imunidades).
} 
utilizada pelo legislador constituinte se deu em homenagem à Aliomar Baleeiro, por força do lançamento de sua obra intitulada "Limitações Constitucionais ao Poder de Tributar"

\subsection{Relação entre Imunidade Tributária e Princípios Constitucionais Tributários}

Consoante dito acima, tanto as imunidades tributárias genéricas quanto os princípios constitucionais tributários compõem o que a Constituição Federal de 1988 denominou de "Limitações Constitucionais ao Poder de Tributar".

Não obstante essas duas figuras estarem contidas na mesma Seção do Capítulo I do Título VI e terem a função de demarcar o âmbito de exercício da competência tributária, atribuída a cada um dos entes políticos, a semelhança entre elas finda por aí.

Tal qual será visto em tópico específico adiante, embora as imunidades tributárias possuam, dentre seus fundamentos, valores e princípios prestigiados constitucionalmente, existem muitas dessemelhanças entre ambos os institutos. Entende-se por "princípios" os "enunciados prescritivos, dotados de elevada carga axiológica, que informam a produção legislativa (normas de estrututa) e a compostura das normas jurídicas reguladoras de condutas intersubjetivas (normas de conduta)." ${ }^{\text {61 }}$.

As imunidades tributárias, por sua vez, tal qual também será demonstrado em tópico específico (item 2.3), por possuírem a natureza de "limites objetivos", são aplicadas a situações, pessoas ou coisas específicas e identificadas na Carta Magna de 1988.

Eis a primeira distinção entre ambos: enquanto os princípios possuem forte carga axiológica, as imunidades tributárias aplicam-se somente às situações, pessoas e coisas constitucionalmente descritas na Lei Maior. Ou seja, somente estaremos diante de uma hipótese de imunidade tributária se a Constituição Federal de 1988 assim o estabelecer de forma expressa.

Afora essa distinção, verifica-se que enquanto as imunidades tributárias inibem o pleno exercício da competência tributária em relação a certas pessoas, coisas ou situações, os princípios atuam como guias a orientar o adequado exercício da competência tributária. Logo,

\footnotetext{
${ }^{60}$ De acordo com Misabel Abreu Machado Derzi: "Essa breve explicação evidencia que ALIOMAR BALEEIRO ainda ocupa a posição de líder - o mais ilustre do pensamento nacional - pois a Constituição de 1988 intitulou a Seção II do Capítulo do Sistema Tributário, 'Das Limitações ao Poder de Tributar', copiando denominação de sua clássica obra, na qual se incluem tanto as imunidades como os princípios" (BALEEIRO, Aliomar; DERZI, Misabel Abreu Machado. Limitações Constitucionais ao Poder de Tributar. 8 ed. atual. Rio de Janeiro: Forense, 2010, p. 854).

${ }^{61}$ BARRETO, Paulo Ayres. Contribuições Regime Jurídico, Destinação e Controle. São Paulo: Editora Noeses, $2^{\mathrm{a}}$ edição, 2011, p. 16.
} 
quando da instituição de um tributo, o ente político verificará quais são os tributos que ele pode criar, verificará os requisitos contidos na Constituição Federal para instituir tal exação, bem como as situações, coisas ou pessoas sobre as quais o ente político não poderá estender seus braços. Assim, a norma de competência resulta da seguinte operação: norma de atribuição de competência - imunidades tributárias = tributo constitucionalmente hábil a ser exigido.

Dito isso, conforme se verifica acima, a única intersecção entre os princípios constitucionais tributários e as imunidades tributárias genéricas diz respeito ao fato de ambos serem "Limitações Constitucionais ao Poder de Tributar". Afora isso, ambos institutos são diametralmente opostos.

Contudo, consoante será delineado abaixo, as imunidades tributárias muitas vezes possuem inspiração em determinados princípios constitucionais. Por esse motivo, Regina Helena Costa menciona que as imunidades são um "princípio da não-obstância de direitos fundamentais por via da tributação" 62 .

\subsubsection{Princípios Constitucionais Tributários aplicáveis às Imunidades}

\section{Tributárias}

Consoante exposto, apesar de as imunidades tributárias não se confundirem com os princípios constitucionais tributários, fato é que aquelas se originam, possuem inspiração, nesses, os quais possuem alta carga valorativa.

Misabel Abreu Machado Derzi ${ }^{63}$, ao elaborar o texto intitulado "A imunidade recíproca, o princípio federal e a Emenda Constitucional n. 3 de 1993”, com grande sapiência sustenta que muitos princípios constitucionais tributários, além dos valores que são resguardados por esses preceitos, serviram de inspiração para a instituição das imunidades tributárias: "A rigor, os princípios, como mandamentos nucleares, como conceitos básicos ou alicerces do sistema jurídico, tanto inspiram as normas atributivas de poder, como aquelas imunitórias. Ora explicam o sentido e a função de uma imunidade, ora a distribuição de poder entre os entes federados, ora são requisitos ou critérios de validade formal ou material, para a criação de normas jurídico-tributárias. Compreendê-los é condição inafastável para a interpretação de qualquer regra".

\footnotetext{
${ }^{62}$ COSTA, Regina Helena. Imunidades Tributárias - Teoria e Análise da Jurisprudência do STF. 2. ed. São Paulo: Malheiros, 2006. p. 119.

${ }^{63}$ DERZI, op. cit., p. 81.
} 
No presente trabalho, apesar de termos ciência e consciência da estreita relação de diversos princípios constitucionais tributários com as imunidades tributárias, tais como o do não confisco, do livre trânsito de pessoas e bens em território nacional e o da uniformidade geográfica, analisaremos somente os princípios que, sob a nossa ótica, estão mais intimamente ligados às normas imunitórias, especialmente às que tratam da imunidade às contribuições sociais destinadas à seguridade social das entidades beneficentes de assistência social, quais sejam, princípios da legalidade, da isonomia e da capacidade contributiva.

\subsubsection{Princípio da legalidade tributária}

O princípio da legalidade tributária está disposto no artigo 150, inciso I, da Constituição Federal de 1988, o qual dispõe que "sem prejuízo de outras garantias asseguradas ao contribuinte, é vedado à União, aos Estados, ao Distrito Federal e aos Municípios: exigir ou aumentar tributo sem lei que o estabeleça”.

Tal disposição constitucional decorre do princípio da legalidade genérica contido no artigo $5^{\circ}$, inciso II, da Constituição Federal de 1998, segundo o qual "ninguém será obrigado a fazer ou deixar de fazer alguma coisa senão em virtude de lei”.

Para entender-se a relação entre imunidade tributária e o princípio da legalidade, faz-se mister compreender a importância desse primado na relação entre Fisco e contribuintes.

Muitos autores remontam à Magna Charta, imposta ao príncipe da Inglaterra JoãoSem-Terra, pelos barões normandos, em 1915 - o nascedouro do princípio no taxation without representation $^{64}$. Contudo, para Luís Eduardo Schoueri, o direito de concordar com a tributação remonta à época das Corporações de Ofício na Idade Média ${ }^{65}$.

Independentemente da época em que surgiu o princípio do no taxation without representation, o que se viu ao longo da história foi uma crescente participação do povo, diretamente ou por meio de representação, na instituição dos tributos ${ }^{66}$. Portanto, a importância do princípio da legalidade, ao longo dos séculos, revelou a necessidade de que aqueles que suportaram os tributos fossem sempre consultados a respeito, o que eleva tal

\footnotetext{
${ }^{64}$ COÊLHO, Sacha Calmon Navarro. Princípios constitucionais em matéria tributária: explícitos, derivados e conexos. In: Princípios constitucionais Fundamentais um Estudo em homenagem ao professor IVES GANDRA DA SILVA MARTINS. São Paulo: Lex, 2005. p. 914.

${ }^{65}$ SCHOUERI, Luis Eduardo. Direito Tributário. 2. ed. São Paulo: Editora Saraiva, 2012. p. 271.

${ }^{66}$ Exceção feita à época do Absolutismo, que perdurou entre os séculos XVI e XVIII, no qual o rei concentrava todos os poderes, criando leis sem aprovação da sociedade, além de impostos e demais tributos de acordo com a situação.
} 
primado à condição de princípio, na medida em que se espera a concordância dos atingidos pela carga tributária.

No que concerne ao princípio da legalidade contido na Constituição Federal de 1988, com o surgimento do Estado constitucional, o qual destaca o Estado Democrático de Direito, passou a ser uma das vigas mestras do ordenamento jurídico brasileiro. Além de representar o marco avançado do Estado de Direito que procura regular os comportamentos, sejam eles individuais ou dos órgãos estatais, por meio da edição de normas jurídicas das quais as leis são a suprema expressão (já que com o primado da lei cessa-se o privilégio da vontade do detentor do poder em detrimento da lei, a qual se presume ser a expressão da vontade coletiva), tal princípio dá garantias ao particular (cidadão) contra os desmandos do Poder Executivo ou do próprio Judiciário.

Por conseguinte, o princípio da legalidade mais se aproxima de uma garantia constitucional do que um direito individual, pois não tutela especificamente um bem da vida, mas assegura ao particular a prerrogativa de repelir as injunções que lhe sejam impostas por outra via que não seja a da lei.

Dessa forma, a Assembleia Constituinte, ao incluir o princípio da legalidade geral (artigo $5^{\circ}$, inciso II) e o princípio da legalidade em matéria tributária (artigo 150, inciso I), pretendeu estabelecer que todos os atos praticados, mormente pela Administração Pública, fossem pautados pelo legalismo sob pena de infração ao primado da legalidade e, consequentemente, ao Estado Democrático de Direito.

Se a vontade do povo, externada pela Assembleia Constituinte, foi a de inserir na Constituição Federal de 1988 dispositivos que estabelecessem a necessidade de as relações entre cidadão e Poder Público - aquele na condição de contribuinte, e este na condição de ente tributante -, serem reguladas pelo princípio da legalidade, é forçoso reconhecer, igualmente, a necessidade de existência de dispositivo constitucional expresso estabelecendo as pessoas, situações ou coisas sobre as quais o ente tributante não pode estender o seu manto arecadatório. Tal "impedimento" é justamente a imunidade tributária. Como é sabido, vige no ordenamento jurídico pátrio a máxima de que, em direito público, somente aquilo que é expressamente previsto em lei é permitido, enquanto que para o direito privado tudo que não é expressamente proibido é permitido.

Portanto, a Constituição Federal de 1988, ao exigir que a relação entre contribuintes e Fisco se dê com fulcro no primado da legalidade, também exige que as exonerações fiscais 
observem o mesmo princípio, ainda como observância do princípio da segurança jurídica que deve nortear as relações entre ambos.

\title{
1.3.1.2. Princípio da isonomia
}

Prescreve a Constituição Federal de 1988, em seu artigo 5º, caput, que "todos são iguais perante a lei, sem distinção de qualquer natureza, garantindo-se aos brasileiros e estrangeiros residentes no País a inviolabilidade do direito à vida, à liberdade, à igualdade, à segurança e à propriedade."

Conforme se verifica acima, o caput do artigo $5^{\circ}$ da Carta Magna de 1988 trata do princípio da igualdade ou da isonomia. É, no dizer de Rui Barbosa, tratar os iguais de forma equivalente e os desiguais na medida da sua desigualdade:

\begin{abstract}
A regra da igualdade não consiste senão em quinhoar desigualmente aos desiguais, na medida em que se desigualam. Nesta desigualdade social, proporcionada à desigualdade natural, é que se acha a verdadeira lei da igualdade. O mais são desvarios da inveja, do orgulho, ou da loucura. Tratar com desigualdade a iguais, ou a desiguais com igualdade, seria desigualdade flagrante, e não igualdade real. Os apetites humanos conceberam inverter a norma universal da criação, pretendendo, não dar a cada um, na razão do que vale, mas atribuir o mesmo a todos, como se todos se equivalessem. ${ }^{67}$
\end{abstract}

A igualdade é pedra angular e fundamenta todos os demais princípios constitucionais. Ela condiciona as funções exercidas pelos Poderes Legislativo, Executivo e Judiciário, de modo que todo e qualquer ato administrativo nunca se poderá furtar da observância desse primado tão caro aos governos republicanos.

Similar ao que ocorre em relação ao princípio da legalidade, tratado de forma específica em matéria tributária (princípio da estrita legalidade), o primado da isonomia também possui a sua expressão em matéria fiscal. É o que estabelece o artigo 150, inciso II, da Constituição ${ }^{68}$.

\footnotetext{
${ }^{67}$ BARBOSA, Rui. Oração aos Moços. 5. ed. Rio de Janeiro: Fundação Casa de Rui Barbosa, 1997. p. 26. Edição popular anotada por Adriano da Gama Kury.

68 “Art. 150. Sem prejuízo de outras garantias asseguradas ao contribuinte, é vedado à União, aos Estados, ao Distrito Federal e aos Municípios:

$[\ldots]$

II - instituir tratamento desigual entre contribuintes que se encontrem em situação equivalente, proibida qualquer distinção em razão de ocupação profissional ou função por eles exercida, independentemente da denominação jurídica dos rendimentos, títulos ou direitos;"
} 
Em âmbito tributário, o princípio da isonomia ainda se faz presente por força do princípio da generalidade da tributação, segundo o qual todos devem pagar os tributos, desde que inseridos na mesma situação geradora da obrigação tributária. Logo, por meio do princípio da generalidade da tributação, não se exige que todas as pessoas, de forma indistinta, recolham os tributos. Demanda-se que todos aqueles socialmente compreendidos pelas normas gerais e abstratas que tratam da incidência dos tributos a que a Constituição Federal de 1988 faz referência deverão entregar parcela de seu patrimônio ao Fisco a título de tributo. Com efeito, somente se sujeitarão à incidência tributária de forma igualitária aquelas pessoas que se encontrarem nas mesmas condições e preencherem todos os requisitos da regra-matriz de incidência tributária ${ }^{69}$.

Sobre a aplicação do princípio da generalidade da tributação no direito brasileiro, Roque Antonio Carraza já teve a oportunidade de discorrer sobre a sua importância e o seus efeitos:

Esta assertiva há de ser bem entendida. Significa, não que todos devem ser submetidos a todas as leis tributárias, podendo ser gravados com todos os tributos, mas, sim, apenas, que todos os que realizam a situação de fato a que a lei vincula o dever de pagar um dado tributo estão obrigados, sem discriminação arbitrária alguma, a fazê-lo.

Assim, é fácil concluirmos que o princípio republicano leva ao princípio da generalidade da tributação, pelo qual a carga tributária, longe de ser imposta sem qualquer critério, alcança a todos com isonomia e justiça. Por outro raio semântico, o sacrifício econômico que o contribuinte deve suportar precisa ser igual para todos os que se acham na mesma situação jurídica. ${ }^{70}$

Da mesma forma que o princípio da isonomia é observado quando da instituição de um tributo que contempla os contribuintes, essa mesma garantia constitucional tem de ser observada quando da instituição de uma exoneração tributária, por exemplo. Contudo, tal exceção não poderá ser estabelecida de forma arbitrária, mas de maneira fundamentada. $\mathrm{Na}$ hipótese de o discrímen ser devidamente fundamentado, observado estará o princípio da igualdade ${ }^{71}$.

E é justamente isso o que ocorre, por exemplo, com as imunidades tributárias descritas nas alíneas "b", “c", "d" e "e" do artigo 150, inciso VI, da Constituição Federal de 1988. Elas

\footnotetext{
${ }^{69} \mathrm{O}$ antecedente da norma geral e abstrata da incidência tributária traz em seu bojo os critérios material, especial e temporal; por sua vez, o consequente da norma é representado pelos critérios subjetivo (sujeito ativo e sujeito passivo) e quantitativo (base de cálculo e alíquota).

${ }^{70}$ CARRAZA, Roque Antonio. Curso de Direito Constitucional Tributário. 29. ed. São Paulo: Malheiros, 2013. p. 87.

${ }^{71}$ Cf. SCHOUERI, 2012, p. 388.
} 
tratam, respectivamente, da imunidade aos impostos dos templos de qualquer culto; dos partidos políticos (inclusive das fundações de tais partidos); das entidades sindicais dos trabalhadores; das instituições de educação e de assistência social sem fins lucrativos; dos livros, jornais, periódicos e o papel destinado a sua impressão; e dos CDs e DVDs com musicas nacionais ou interpretadas por artistas brasileiros.

Em todos esses casos, o discrímen no qual se assenta a exoneração físcal consiste na relevância do papel desempenhado pelas entidades que auxiliam o Estado brasileiro na supressão de suas deficiências em suas diversas áreas de atuação; ou, ainda, no especial interesse do Poder Público em prestigiar determinadas situações, já que imbuídas de valores deveras caros em uma sociedade que possui como fundamentos a soberania, a cidadania, a dignidade da pessoa humana, os valores sociais do trabalho e da livre iniciativa e o pluralismo político, nos termos do artigo $1^{\circ}$, da Carta Política de $1988^{72}$. Este mesmo entendimento se aplica às imunidades tributárias que possuem por fundamento garantir algum direito e/ou garantia individual, na medida em que trazem consigo uma forte carga valorativa.

Isto posto, visando ao cumprimento da máxima atrelada ao princípio da isonomia, segundo a qual os iguais serão tratados de forma equânime e os desiguais de forma diferenciada na medida da sua desigualdade, a Constituição Federal de 1988, ao estabelecer pessoas, situações ou coisas sobre as quais o Poder Público não poderá lançar seus tentáculos arrecadatórios, dá plena efetividade ao princípio da igualdade insculpido no artigo $5^{\circ}$, caput e repisado, com uma roupagem específica no artigo 150, inciso II.

\subsubsection{Princípio da capacidade contributiva}

O princípio da capacidade contributiva está disposto no artigo $145, \S 1^{\circ}$, da Constituição Federal de 1988, que assim dispõe:

Art. 145 - A União, os Estados, o Distrito Federal e os Municípios poderão instituir os seguintes tributos:

$[\ldots]$

\footnotetext{
72 “A República Federativa do Brasil, formada pela união indissolúvel dos Estados e Municípios e do Distrito Federal, constitui-se em Estado Democrático de Direito e tem como fundamentos:

I - a soberania;

II - a cidadania

III - a dignidade da pessoa humana;

IV - os valores sociais do trabalho e da livre iniciativa;

V - o pluralismo político.”
} 
$\S 1^{\circ}$ - Sempre que possível, os impostos terão caráter pessoal e serão graduados segundo a capacidade econômica do contribuinte, facultado à administração tributária, especialmente para conferir efetividade a esses objetivos, identificar, respeitados os direitos individuais e nos termos da lei, o patrimônio, os rendimentos e as atividades econômicas do contribuinte.

Tal princípio é uma explicitação do princípio da solidariedade, já que a solidariedade constitui um dos objetivos da República Federal do Brasil, de acordo com o artigo 3, inciso I, da Constituição Federal pátria ${ }^{73}$. E o atingimento desse objetivo se dá justamente por meio da observância da máxima de que cada um contribuirá com quanto puder para o bem da coletividade.

O princípio da capacidade contributiva corresponde, dessa forma, à manifestação de justiça no âmbito fiscal, na medida em que ele possui sua gênese no princípio da igualdade. Por meio do princípio da capacidade contributiva devem-se pautar não só o Poder Legislativo, mas também o Executivo e o Judiciário, visto constituir-se em baliza a ser utilizada no momento da elaboração normativa, assim como na aplicação da lei tributária.

Para Regina Helena Costa, entende-se por capacidade contributiva a "aptidão, da pessoa colocada na posição de destinatário legal tributário, para suportar a carga tributária, sem o perecimento da riqueza lastreada da tributação",74. Por conseguinte, a capacidade contributiva é a aptidão que cada pessoa possui para contribuir com as despesas públicas do Estado, levando em consideração a sua riqueza disponível à tributação, já "descontada" a parcela necessária a sua subsistência.

Antes de prosseguirmos, faz-se necessário distinguir capacidade econômica de capacidade contributiva, diferença essa deveras importante para fixar-se a existência ou não de relação entre o primado da capacidade contributiva e as imunidades tributárias.

Heleno Taveira Torres, em sua obra intitulada "Direito constitucional tributário e segurança jurídica: metódica da segurança jurídica do sistema constitucional tributário" disserta acerca da distinção entre capacidade econômica e capacidade contributiva. São suas as seguintes palavras:

A capacidade contributiva diz respeito unicamente à parcela da capacidade econômica integral do contribuinte, aquela que é alcançada pelos tributos ou que pode ser objeto de tributação, afastado o mínimo existencial e aquelas formas de manifestações econômicas que se possam gravar com tributos.

\footnotetext{
73 “Art. $3^{\circ}$ Constituem objetivos fundamentais da República Federativa do Brasil:

I - construir uma sociedade livre, justa e solidária; [...]."

${ }^{74}$ COSTA, Regina Helena. Princípio da capacidade contributiva. 3. ed. São Paulo: Malheiros, 2003. p. 107.
} 
Dito de outro modo, a revelação de capacidade contributiva faz-se a partir da esfera de capacidade econômica do contribuinte, limitadamente ao âmbito das manifestações materiais suscetíveis de serem oferecidas à tributação e preservada a reserva do mínimo vital em matéria tributária. ${ }^{75}$

Mais adiante em seu texto, o autor aduz que:

a capacidade econômica de cada pessoa é um 'universal' do qual faz parte a capacidade de pagar tributos. Em si mesma, a capacidade contributiva só é 'direito' no que corresponde à proteção da propriedade, da isonomia e da previsibilidade (certeza) de limitação da carga tributária segundo critérios coerentes $^{76}$.

Consequentemente, a capacidade econômica representa uma fase pré-capacidade contributiva, uma vez que se volta à totalidade da riqueza do contribuinte e não àquela passível de tributação. Na capacidade econômica encontram-se todas as parcelas necessárias à obtenção de renda por parte do indivíduo, assim como os valores necessários à sua subsistência e à de seus familiares, as quais são inatingíveis pela tributação por corresponderem ao seu mínimo vital.

Sendo assim, somente será possível falar-se em capacidade contributiva, parcela de renda efetivamente tributável, na hipótese de restar um saldo positivo após a realização da seguinte operação matemática:

CAPACIDADE CONTRIBUTIVA = riqueza - despesas necessárias à subsistência da pessoa e de seus familiares.

Sem capacidade econômica suficiente para a subsistência, ou apenas suficiente, não há que se falar em tributação. Dessa maneira, é possível dizer que a capacidade contributiva não subsiste sem a capacidade econômica, ainda que a recíproca não seja verdadeira.

É justamente por esse motivo que a doutrina, a fim de elucidar a aplicação do princípio da capacidade contributiva, utiliza o exemplo clássico daquela pessoa que aufere renda. $\mathrm{O}$ indivíduo, portanto, possui capacidade econômica, porém seu estado de saúde precário obriga-o a gastar toda sua renda com medicamentos, hospital, médicos; ou seja, despender todos seus ganhos na tentativa de curar a mazela da qual sofre. Nesse caso, apesar de possuir

\footnotetext{
${ }^{75}$ TORRES, op. cit., p. 599.

${ }^{76}$ TORRES, op. cit., p. 600. 
capacidade econômica, essa pessoa não possui capacidade contributiva, já que toda sua renda destina-se ao seu mínimo vital ${ }^{77}$.

Em vista disso, a única "capacidade" passível de tributação é a contributiva e não a econômica. Vale referir que a capacidade contributiva possui duas feições: a relativa (subjetiva) e a absoluta (objetiva).

A capacidade contributiva subjetiva traduz-se na existência de uma riqueza passível de tributação. Funciona também como critério de graduação dos tributos e como limite da tributação, obstando, desta forma, que a progressividade tributária atinja níveis de confisco ou de cerceamento de outros direitos constitucionais. Destarte, o objetivo da capacidade contributiva subjetiva é saber se o contribuinte pode ou não suportar a carga tributária.

Do ponto de vista objetivo, utiliza-se a capacidade contributiva como parâmetro para definir-se pela tributação ou não de determinadas situações. Desse modo, o mote da capacidade contributiva objetiva é, de forma bem específica, descrever as situações do mundo fenomênico passíveis de tributação. Alfredo Augusto Becker denominou essas situações de "signos presuntivos de riqueza"

Diferentemente do que ocorre com a capacidade contributiva subjetiva, na configuração da capacidade contributiva objetiva não se perquire se determinado contribuinte pode ou não pagar o tributo, porquanto o legislador, visando à concretude do princípio da isonomia, mencionará as situações sobre as quais recairá a incidência tributária.

Sobre a distinção entre capacidade contributiva subjetiva e objetiva, Luís Eduardo Schoueri alega que

A capacidade contributiva pode ser: (i) um limite ou critério para a graduação da tributação; ou (ii) um parâmetro para a distinção entre situações tributáveis e não tributáveis. No primeiro caso, falar-se-á em capacidade relativa ou subjetiva; no último, em capacidade contributiva absoluta ou objetiva. Esta será a "existência de uma riqueza apta a ser tributada (capacidade contributiva como pressuposto de tributação)", enquanto no sentido subjetivo, será "parcela dessa riqueza que será objeto da tributação em face de condições individuais (capacidade contributiva como critério de graduação e limite do tributo),"79

\footnotetext{
${ }^{77}$ Nesse sentido: SCHOEURI, Luis Eduardo. Direito Tributário. 2. ed. São Paulo: Editora Saraiva, 2012. p. 389; e BALEEIRO, Aliomar; DERBI, Misabel Abreu Machado. Limitações Constitucionais ao Poder de Tributar. ed. atual. Rio de Janeiro: Forense, 2010. p. 1158.
}

${ }^{78}$ BECKER, Alfredo Augusto. Teoria geral do direito tributário. 5. ed. São Paulo: Noeses, 2010. p. 539.

${ }^{79}$ SCHOEURI, Luis Eduardo. Direito tributário. 2. ed. São Paulo: Editora Saraiva, 2012. p. 322. 
Trazendo a interpretação da capacidade contributiva objetiva e relativa às imunidades tributárias, constata-se que a intributabilidade constitucionalmente garantida decorre da ausência de capacidade contributiva subjetiva de seus destinatários. Se o tributo é um instrumento de captação de capacidade contributiva, sua ausência implica na impossibilidade de imposição fiscal.

Isso porque, tal qual aduzido ao longo do presente trabalho científico, as entidades "agraciadas" com o manto da imunidade a que se refere o artigo 150, inciso VI, alíneas "a", "b" e "c" da Constituição Federal de 1988, não possuem capacidade contributiva subjetiva, uma vez que toda a arrecadação auferida é voltada para adimplir os gastos da coletividade nos casos da imunidade recíproca - ou para utilização na consecução de seus objetivos sociais, os quais se prestam a auxiliar o Estado no seu mister.

Ocorre, contudo, que, haverá casos em que o princípio da capacidade contributiva não servirá de gênese para a aplicação de determinada imunidade. Isso se dá em virtude de a Constituição Federal de 1988 ter elencado em seu bojo imunidades que visam não a resguardar um valor extremamente caro à sociedade, mas a atender interesses políticos e/ou econômicos. Nesses casos, diz-se que as imunidades tributárias possuem fundamento, única e exclusivamente, no princípio da legalidade, sobre o qual tratamos no item 1.2.1.1 acima.

\subsubsection{Imunidades Tributárias}

O outro grupo que compõe as constitucionalmente denominadas "Limitações Constituições ao Poder de Tributar" é representado pelas imunidades tributárias.

Consoante aduzido anteriormente, apesar de o legislador constitucional mencionar que somente os artigos 150 a 152 tratam das "Limitações Constitucionais ao Poder de Tributar", verificou-se, no item 1.2 acima, que tal assertiva não representa a realidade, porquanto o próprio texto constitucional, em diversos outros dispositivos, trata tanto dos princípios constitucionais tributários quanto das imunidades tributárias.

As únicas imunidades componentes da Seção destinada às "Limitações Constitucionais ao Poder de Tributar" são as imunidades ditas genéricas ${ }^{80}$. As demais estão dispostas em diversos outros dispositivos constitucionais.

\footnotetext{
${ }^{80}$ Entende-se por imunidade genérica as que possuem por objeto tratar de vedação a todas as pessoas jurídicas e abranger todo e qualquer tributo incidente sobre renda, patrimônio ou serviço das entidades a que o artigo 150 , inciso VI, alíneas "a", "b", "c", da Constituição Federal de 1988. O mesmo entendimento se aplica à imunidade dos livros, CDs e DVDs, a que as alíneas "d" e "e" desse mesmo dispositivo constitucional fazem alusão.
} 
Como exemplo, podemos, uma vez mais, citar a imunidade tributária às contribuições sociais destinadas à seguridade social das entidades beneficentes de assistência social, disposta no artigo 195, $\S 7^{\circ}$, da Constituição Federal. E é justamente sobre essa segunda espécie de "Limitações Constitucionais ao Poder de Tributar" que nossos estudos serão destinados a partir deste momento. 


\section{CAPÍTULO II - CONCEITO DE IMUNIDADE TRIBUTÁRIA E QUESTÕES CONEXAS}

\subsection{Natureza Jurídica e Conceito de Imunidade Tributária}

Conforme referido em tópico antecedente, a Constituição Federal de 1988 é extremamente rígida no que diz respeito às questões de cunho tributário. Tanto é verdade que ela, de forma minudente, traçou e delimitou o campo de abrangência e competência da União, dos Estados, do Distrito Federal e dos Municípios.

Da mesma forma que a Carta Magna de 1988 desenhou o espectro de atuação de cada ente político, ela forjou, de maneira negativa, o campo sobre o qual esses mesmos entes políticos não podem exercer a competência tributária.

Essas normas constitucionalmente negativas são as chamadas imunidades tributárias. Em outras palavras, as imunidades tributárias, ao estabelecerem as situações, pessoas ou coisas sobre as quais União, Estados, Distrito Federal e Municípios não poderão estender o manto tributário, auxiliam na correta demarcação da competência impositiva tributária de cada um desses entes.

Apesar de as imunidades tributárias terem surgido no ordenamento jurídico pátrio com a Constituição de $1824^{81}$, a doutrina ainda é vacilante no que concerne à natureza jurídica das imunidades tributárias e, consequentemente, de seu conceito:

- $\quad$ se limitação constitucional ao poder de tributar;

- $\quad$ se hipótese de não incidência juridicamente qualificada na Constituição Federal de 1988;

- $\quad$ ou se norma jurídica que demarca a incompetência dos entes para tributar determinadas pessoas, situações ou coisas.

Não é por outro motivo que Paulo de Barros Carvalho menciona que "o estudo científico das imunidades jurídico-tributárias não encontrou ainda uma elaboração teórica metodologicamente adequada ao conhecimento de sua fenomenologia" ${ }^{\circ 2}$.

Por conta disso, não obstante o objeto imediato do presente trabalho científico estar relacionado à imunidade das contribuições sociais destinadas à seguridade social das

\footnotetext{
${ }^{81}$ Nesse sentido: COSTA, Regina Helena. Imunidades Tributárias Teoria e Análise da Jurisprudência do STF. 2. ed. São Paulo: Malheiros, 2006. p. 28.

${ }^{82}$ CARVALHO, Paulo de Barros. Imunidades Tributárias. In: São Paulo: Noeses, 2009. p. 308. Direito tributário linguagem e método.
} 
entidades beneficentes de assistência social, entendemos ser necessário trazer à discussão o posicionamento da mais abalizada doutrina relacionada à natureza jurídica desse instituto.

Inúmeros doutrinadores, ao longo dos anos, teceram diversos comentários sobre a natureza jurídica das imunidades tributárias. Aliomar Baleeiro ${ }^{83}$. e Ruy Barbosa Nogueira ${ }^{84}$ defenderam a tese de que as imunidades tributárias correspondem à limitações constitucionais ao poder de tributar. Para Amílcar deAraújo Falcão, a imunidade é "uma forma qualificada ou especial de não incidência, por supressão, na Constituição, da competência impositiva ou do poder de tributar, quando se configuram certos pressupostos, situações ou circunstâncias previstos no Estatuto Supremo" $" 85$.

Existe, ainda, uma terceira e majoritária corrente que vislumbra na imunidade tributária uma norma de estrutura que auxilia na demarcação da competência tributária atribuída à União, aos Estados, ao Distrito Federal e aos Municípios, na medida em que ela proíbe o seu exercício em relação a determinados bens, pessoas ou fatos.

São adeptos dessa corrente doutrinária Aires F. Barreto ${ }^{86}$, Heleno Taveira Torres ${ }^{87}$, Humberto Ávila ${ }^{88}$, José Eduardo Soares de Melo ${ }^{89}$, Luís Eduardo Schoueiri ${ }^{90}$, Misabel Abreu Machado Derzi $^{91}$, Paulo Ayres Barreto ${ }^{92}$, Paulode Barros Carvalho ${ }^{93}$, Regina Helena Costa ${ }^{94}$ e Roque Antonio Carraza ${ }^{95}$.

Por todos, vejam-se as considerações de Aires F. Barreto e Paulo Ayres Barreto acerca do conceito de imunidade tributária:

\footnotetext{
${ }^{83}$ BALEEIRO, Aliomar. Imunidades e isenções tributárias. In: Revista de Direito Tributário n. 1. São Paulo: Malheiros, 1977. p. 70.

${ }^{84}$ NOGUEIRA, Ruy Barbosa. Da interpretação e da aplicação das leis tributárias. 2. ed. São Paulo: Revista dos Tribunais, 1974.

${ }^{85}$ FALCÃO, Amílcar de Araújo. Imunidade e Isenção Tributária - Instituição de Assistência Social. Revista de Direito Administrativo, Rio de Janeiro, v. 66, p. 370, 1961.

${ }^{86}$ BARRETO, Aires F. e BARRETO, Paulo Ayres. Imunidades tributárias: limitações constitucionais ao poder de tributar. 2. ed. São Paulo: Dialética, 2001. p. 11-12.

${ }^{87}$ TORRES, Heleno Taveira. Direito constitucional tributário e segurança jurídica: metódica da segurança jurídica do sistema constitucional tributário. São Paulo: Revista dos Tribunais, 2011. p. 611.

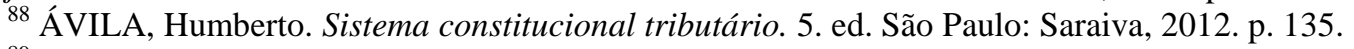

${ }^{89}$ MELO, José Eduardo Soares de. Curso de Direito Tributário. São Paulo: Dialética, 1997. p. 89.

${ }^{90}$ SCHOUERI, Luís Eduardo. Direito Tributário. 2. ed. São Paulo: Saraiva, 2012. p. 224.

${ }^{91}$ BALEEIRO, Aliomar; DERBI, Misabel Abreu Machado. Limitações Constitucionais ao Poder de Tributar. ed. atual. Rio de Janeiro: Forense, 2010, p. 228.
}

92 BARRETO, Aires F. e BARRETO, Paulo Ayres. Imunidades tributárias: limitações constitucionais ao poder de tributar. 2. ed. São Paulo: Dialética, 2001. p. 11-12.

${ }_{93}$ CARVALHO, Paulo de Barros. Curso de Direito Tributário. 26. ed. São Paulo: Saraiva, 2014. p. 236.

${ }^{94}$ COSTA, Regina Helena. Imunidades tributárias: teoria e análise da jurisprudência do STF. 2. ed. São Paulo: Malheiros, 2006. p. 52.

${ }^{95}$ CARRAZA, Roque Antonio. Curso de Direito Constitucional Tributário. 29. ed. São Paulo: Malheiros, 2013. p. 735 . 
[...] Quer dizer: a própria Constituição, ao traçar a competência tributária, proíbe o seu exercício em relação a eles. Em outras palavras, não concede competência tributária em relação a certos bens, pessoas e fatos. As imunidades tributárias são, portanto, matéria pertencente à disciplina constitucional da competência tributária. Configuram as mais importantes "limitações constitucionais ao poder de tributar", como indelevelmente batizadas por Aliomar Baleeiro.

[...]

As imunidades tributárias definem uma área textualmente subtraída à competência legislativa (em matéria tributária) das pessoas constitucionais; é dizer: elas não têm competência para editar leis que instituam tributos sobre os fatos, pessoas ou bens imunizados, subtraídos à tributação. Eles estão, em suma, fora da área de competência tributária. Deveras - ao traçar a competência tributária -, o constituinte edita disposições que contêm regras positivas, atributivas de competência e, simultaneamente, as que contêm regras negativas da atribuição da competência. Logo, a competência tributária já nasce delimitada na própria Constituição que, explicitamente, prevê a impossibilidade de os entes políticos-constitucionais virem a gravar, com tributos, as situações que, rigorosamente, tipifica como imunes à tributação. ${ }^{96}$

Da leitura dos trechos acima transcritos, verifica-se que os principais e mais contemporâneos doutrinadores pátrios possuem o entendimento de que a competência tributária dos entes políticos é forjada pela junção das normas de incompetência tributária, que tratam da imunidade, e normas instituidoras dos tributos, as quais se prestam, única e exclusivamente, a delimitar o campo de atuação da União, dos Estados, do Distrito Federal e dos Municípios.

Em outras palavras, o legislador constituinte, ao traçar a competência tributária de cada ente político, editou disposições que contém regras positivas, atributivas de competência e, simultaneamente e não em momento cronológico anterior, as que contêm regras negativas da atribuição de competência, as denominadas imunidades tributárias.

Em vista disso, quando o legislador infraconstitucional for editar normas visando à instituição de tributo, ele deverá observar os caminhos a serem trilhados tendo como baliza as normas que estabelecem os critérios da regra-matriz de incidência tributária, os princípios constitucionais tributários aplicáveis a cada espécie tributária e as imunidades tributárias.

Apesar de o posicionamento acima ser o predominante na doutrina pátria, com o qual nos filiamos, ele contrasta, tal qual aduzido, com o entendimento de parte da doutrina nacional que vislumbra na imunidade tributária hipótese de limitação constitucional à

\footnotetext{
${ }^{96}$ BARRETO, Aires F. e BARRETO, Paulo Ayres. Imunidades tributárias: limitações constitucionais ao poder de tributar. 2. ed. São Paulo: Dialética, 2001. p. 11.
} 
competência tributária ${ }^{97}$; exclusão ou supressão de competências tributárias ${ }^{98}$; ou não incidência tributária constitucionalmente qualificada ${ }^{99}$.

Por mais que existam, conforme visto, inúmeros posicionamentos relativos à natureza jurídica da norma de imunidade tributária, entendemos que a explanação que melhor se amolda ao Sistema Constitucional Tributário pátrio é a que considera a norma de imunidade tributária como norma inibidora da competência tributária. Então, a competência tributária dos entes políticos é estabelecida pela aglutinação de normas negativas (imunidades tributárias) e normas positivas (instituidoras dos tributos), as quais se prestam, única e exclusivamente, a delimitar o campo de atuação da União, dos Estados, do Distrito Federal e dos Municípios.

Em outras palavras, o legislador constituinte, ao traçar a competência tributária de cada ente político, editou disposições que contêm regras positivas, atributivas de competência e, ao mesmo tempo, as que contêm regras negativas da atribuição de competência.

\footnotetext{
${ }^{97}$ Entendemos que não há que se falar em limitação constitucional à competência tributária, pois que, conforme aduzido, inexiste cronologia que justifique em momento anterior a atribuição da competência tributária para, em momento, posterior, ser retirada parcela dessa competência pela regra imunizante. A regra imunizante trata, em verdade, de uma das múltiplas formas de demarcação da competência, congregando-se às demais para produzir o campo em que as pessoas políticas haverão de operar em matéria tributária.

O que limita a competência caminha em sentido contrário a ela, seja suprimindo-a, seja mutilando-a, enquanto a norma que estabelece a hipótese de imunidade auxilia no desenho constitucional da faixa de competência concedida aos entes tributantes.

${ }^{98} \mathrm{Na}$ imunidade não há, outrossim, supressão ou exclusão de competências tributárias. Conforme os ensinamentos de Paulo de Barros Carvalho em sua obra Curso de Direito Tributário (São Paulo: Saraiva, 26 ed., 2014, p. 225), na medida em que o termo "excluir", que deriva do latim excludere, significa expulsar, excetuar, afastar; "suprimir", por seu turno, que deriva do latim supprimere, possui a acepção de extinguir, fazer desaparecer, eliminar, anular. Dessa forma, as palavras "excluir" e "suprimir" pressupõem a existência de algo que, posteriormente, será excluído ou suprimido.

Ocorre, todavia, que as imunidades tributárias não atuam em momento posterior à definição das faixas de competência tributária atribuídas a cada um dos entes tributantes, mas sim em momento lógico idêntico.

Em suma, a competência tributária representa tão somente o resultado de uma conjugação de normas constitucionais, dentre as quais as de imunidade tributária. A competência para legislar, quando surge, já vem com as demarcações que os preceitos da Constituição Federal de 1988 fixaram.

${ }^{99}$ Por fim, cumpre-nos aduzir que as regras imunizantes também não podem ser consideradas como hipótese de não incidência constitucionalmente qualificada, porquanto as imunidades tributárias são normas de estrutura, as quais se prestam a limitar ou estabelecer outros meios de conduta para a construção de normas de conduta.

Por seu turno, as normas que tratam da incidência são normas de conduta, haja vista estabelecerem os critérios da regra-matriz de incidência dos tributos. Ora, se ambas as normas possuem funções distintas, é de todo equivocado mencionar que as regras imunizantes se caracterizam como normas que estabelecem a não incidência.

Ademais, é inconcebível não ter havido o fenômeno da subsunção do fato à norma e, mesmo assim, falar-se em efeitos jurídicos daí decorrentes. É justamente por incidir que a proposição normativa qualifica as pessoas, coisas e estados de coisas, assim como é incidindo que o sistema atinge a disciplina integral do relacionamento intersubjetivo.
}

Dessa forma, aduzir que a regra não incide equivale a negar-lhe tom de juridicidade, marca indelével das unidades jurídico-normativas. 


\subsubsection{Conceito de Imunidade Tributária adotado no presente trabalho científico}

Levando as assertivas acima em consideração, propomos a seguinte conceituação do fenômeno constitucional denominado "imunidade tributária": norma de estrutura contida exclusivamente no texto constitucional que, ao expressamente estabelecer as situações, coisas ou pessoas sobre as quais não poderá recair a tributação, auxilia na demarcação da competência impositiva tributária da União, Estados, Distrito Federal e Municípios.

Com o propósito de melhor elucidar o conceito acima delineado, entendemos por bem segregá-lo, de modo a justificar a escolha feita por essa definição:

\section{Norma de estrutura}

O direito positivo é composto por dois grandes grupos de normas jurídicas: as normas de comportamento e as normas de estrutura. Aquelas possuem por objeto regular a conduta intersubjetiva; já essas se prestam a regular a produção normativa.

Tendo em vista que as imunidades tributárias possuem como destinatário direto o legislador infraconstitucional, entendemos que essas normas jurídicas possuem a natureza de "normas de estrutura" conforme auxiliam os legisladores federal, estadual ou municipal a forjar suas competências tributárias por meio da descrição das situações, pessoas ou objetos sobre os quais não deverá haver a incidência de determinado tributo.

\section{2. contida exclusivamente no texto constitucional}

Em virtude de as imunidades tributárias só poderem ser veiculadas por meio da Constituição Federal de 1988 (diferentemente do que se dá em relação às normas isentivas, tal qual será demonstrado adiante), mencionou-se na conceituação escolhida que elas estão "contidas exclusivamente no Texto Constitucional".

\section{3. que, ao expressamente estabelecer as situações, coisas ou pessoas} sobre as quais não poderá recair a tributação,

Conforme também será exposto adiante, entendemos que as normas jurídicas que veiculam as imunidades tributárias possuem a natureza de limite objetivo, porquanto encerram comandos específicos e diretos endereçados ao legislador infraconstitucional a respeito dos acontecimentos do mundo social, pessoas ou coisas sobre os quais não poderá haver a incidência tributária, não obstante estejam impregnadas de carga axiológica. 
Por possuírem essa feição de limite objetivo, as normas jurídicas que tratam das imunidades tributárias encerram comandos específicos e diretos endereçados ao legislador infraconstitucional que, por conta disso, não possui qualquer espécie de liberdade para estabelecer regras de comportamento com o intuito de tributar as pessoas, situações ou coisas expressamente excluídas do seu campo de atuação arrecadatória, mesmo que tais regras venham de encontro a seus valores morais.

Se o legislador constituinte original pinçou acontecimentos específicos do mundo fenomênico que não poderiam ser objeto de tributação e os incluiu no texto constitucional, comprovada está a condição de limite objetivo das imunidades tributárias, ao passo que houve a pré-demarcação do campo de atuação estatal por meio de descrição das hipóteses sobre as quais não pode haver a instituição de tributos.

\section{4. auxilia na demarcação da competência impositiva tributária da União, dos}

\section{Estados, do Distrito Federal e dos Municípios.}

A Constituição Federal de 1988, ao estabelecer os limites da competência impositiva tributária do Fisco, além de ter forjado, de forma minuciosa, o caminho a ser traçado por esses entes, definiu as situações, coisas e pessoas sobre as quais pode recair a incidência de tributos, assim como as situações, coisas ou pessoas que NÃO podem se sujeitar à incidência tributária.

Com efeito, a fim de instituir os tributos de sua competência, cada ente político deverá levar em consideração a existência de normas atributivas de competência tributária, as balizas que norteiam a atuação dos entes para a instituição dos tributos de sua competência (princípios constitucionais tributários), bem como as regras que tratam das situações, coisas ou pessoas sobre as quais a União, os Estados, o Distrito Federal e os Municípios não podem alcançar por expressa vedação constitucional nesse sentido: as chamadas imunidades tributárias.

Visando à elucidação dessa "regra aritmética" que compõe a competência tributária dos entes políticos brasileiros, elaboramos o seguinte esquema matemático:

COMPETÊNCIA TRIBUTÁRIA = Normas atributivas de competência + princípios constitucionais tributários - imunidades tributárias 
Sendo assim, sempre que a União, os Estados, o Distrito Federal e os Municípios forem instituir os tributos a que a Constituição Federal de 1988 faz referência, tal "fórmula matemática" deverá ser observada sob pena de inobservância das regras constitucionais que tratam da competência tributária.

\subsection{Distinção entre imunidade, isenção e não incidência}

Entre nós, não só no linguajar coloquial como também em ambientes jurídicos, percebe-se uma certa confusão no emprego dos conceitos de imunidade tributária, de isenção e de não incidência.

Aliomar Baleeiro, em aula ministrada em 24 de novembro de 1973, no IV Curso de Especialização em Direito Tributário, na Faculdade de Direito da Pontifícia Universidade Católica de São Paulo (PUC), sobre o tema "Imunidade e Isenções Tributárias", alertou seus interlocutores de que o equívoco na utilização dos termos "imunidade" e "isenção" era mais comum no início dos estudos do Direito Financeiro no Brasil. Contudo, ainda de acordo com esse doutrinador, a partir do ano de 1940, doutrina e jurisprudência passaram a distinguir, de forma correta, essas duas formas exonerativas, de modo que, na sua visão, não haveria mais "necessidade de perdermos tempo nesses conceitos doutrinários"100.

Mesmo levando em conta as considerações de Aliomar Baleeiro feitas acima, entendemos ser salutar frisar as distinções existentes entre "imunidade, "isenção" e "não incidência", principalmente entre os dois primeiros institutos, especialmente porque o legislador constituinte de 1988, ao tratar da imunidade das contribuições sociais destinadas à seguridade social das entidades beneficentes de assistência social, utilizou-se de terminologia errônea ao se referir à concessão de "isenção" a essas entidades ao invés de referir-se à "imunidade tributária".

Conforme fartamente aduzido no tópico anterior (item 2.1.1), entende-se por imunidade tributária as normas de estrutura, expressamente contidas na Constituição Federal de 1988, que se prestam a delimitar a competência impositiva tributária de cada ente político (União, Estados, Distrito Federal e Municipal), na medida em que estabelecem as situações, pessoas ou coisas sobre as quais não há que se falar em imposição tributária.

${ }^{100}$ BALEEIRO, Aliomar. Imunidade e isenções tributárias. In: Revista de Direito Tributário n. 1, São Paulo: Malheiros, 1977. p. 69. 
Por conseguinte, visando a resguardar preceitos extremante caros à sociedade brasileira, a Assembleia Nacional Constituinte entendeu por bem inserir no texto constitucional inúmeros valores políticos, religiosos, educacionais, sociais, culturais e econômicos a serem protegidos contra os desmandos dos Poderes Legislativo, Executivo ou Judiciário.

Por conta desse pano de fundo de atender a certos fins de relevante interesse público, as imunidades tributárias, consoante veremos em tópico específico, são interpretadas de forma ampla. Sobre a conceituação e a definição de imunidade das isenções de impostos não há um posicionamento uníssono. Tendo em vista que o presente trabalho acadêmico não possui por mote tratar das inúmeras teorias ${ }^{101}$ que tentam explicar a fenomenologia da isenção, discorreremos de forma não tão breve somente no que concerne à teoria com a qual concordamos. Trata-se da teoria de Paulo de Barros Carvalho.

\footnotetext{
${ }^{101}$ A título ilustrativo, faz-se prudente mencionar as demais teorias sobre a figura isentiva existentes em nosso ordenamento jurídico:

O primeiro doutrinador a conceituar "isenção tributária" foi Rubens Gomes de Sousa que, baseando-se na dogmática europeia, criou uma teoria visando à definição do instituto de isenção. Para esse doutrinador, isenção é um favor legal consubstanciado na dispensa do pagamento de determinado tributo (SOUSA, Rubens Gomes de. Compêndio de legislação tributária. ed. póstuma. São Paulo: Resenha Tributária, 1975. p. 97.). Essa, inclusive, foi a teoria adotada pelo artigo 175, inciso I, do Código Tributário Nacional.

Insurgindo-se contra a teoria clássica, Alfredo Augusto Becker, inspirado na divisão das normas jurídicas de Pontes de Miranda (normas juridicizantes, desjuridicizantes e não-juridicizantes), bem como nos postulados da Teoria Geral do Direito, procurou demonstrar a inconsistência dessa teoria. Para Becker, "a regra jurídica de isenção incide para que a de tributação não possa incidir" (BECKER, Alfredo Augusto. Teoria geral do direito tributário. 5. ed. São Paulo: Noeses, 2010. p. 327). Para esse doutrinador, não existe aquela anterior relação jurídica e respectiva obrigação tributária que seriam desfeitas pela incidência da regra jurídica de isenção, uma vez que falta ou excede um dos elementos da composição da hipótese de incidência. Sendo assim, a regra jurídica de isenção sempre terá por fim negar a existência de uma relação jurídica tributária.

José Souto Maior Borges também se enveredou pelos caminhos da conceituação do instituto da isenção. Para ele, a isenção é norma excepcional que regula fatos isentos, diversamente de que seriam eles regulados se sobre eles incidisse a regra jurídica de tributação. Diz ele: "a norma que isenta é uma norma jurídica limitadora ou modificadora: restringe o alcance das normas jurídicas de tributação; delimita o âmbito material ou pessoal a que deverá estender-se o tributo ou altera a estrutura do próprio pressuposto de sua incidência" (BORGES, José Souto Maior. Teoria geral da isenção tributária. São Paulo: Malheiros, 2007. p. 163). Na isenção não ocorre a incidência da norma jurídica tributária e, portanto, não se dá o nascimento do tributo. Ou seja, a norma isentiva incide justamente para que a norma tributária não possa incidir. À essa teoria deu-se o nome de "hipótese de nãoincidência, legalmente qualificada".

De acordo com Roque Antonio Carraza, existe, também, uma "nova" teoria criada por um ex-orientando seu, Eliud José Pinto da Costa, a qual, baseada nas lições de Paulo De Barros Carvalho a respeito da matéria, estabeleceu que a norma jurídica isentiva não possui a função de mutilar parcialmente um dos critérios do antecedente ou do consequente, mas sim de dar nova "fisionomia à norma jurídica tributária que, assim, deixa de alcançar certos fatos (CARRAZA, Roque Antonio. Curso de Direito Constitucional Tributário. 29. ed. São Paulo: Malheiros, 2013. p. 999). Esse também é o posicionamento de Luís Eduardo Schoeuri, para quem "o fato de um texto prever uma incidência e outro versar sobre a isenção não implica a existência de duas normas, com incidências distintas; mais adequado é contemplar-se, ali, uma única norma, fruto da combinação de todos os mandamentos legais. A norma de incidência surgirá, pois, como um resultado do esforço do aplicador da lei" (SCHOUERI, Luís Eduardo. Direito Tributário. 2. ed. São Paulo: Saraiva, 2012. p. 621).
} 
Esse doutrinador, com a intenção de definir o instituto da isenção, partiu da divisão das normas jurídicas em normas de comportamento e em normas de estrutura, inserindo, nestas últimas, as regras de isenção.

Observando que as regras isentivas são normas de estrutura, Paulo de Barros Carvalho deduziu que "a regra de isenção investe contra um ou mais critérios da norma [jurídica tributária] [...], mutilando-os, parcialmente" (CARVALHO, 2014, p. 568-569). É importante mencionar que, nos termos do artigo 176 do Código Tributário Nacional ${ }^{102}$, as isenções só podem ser tratadas por meio de lei.

Com base nessas premissas, esse doutrinador conceituou "isenção" como sendo a limitação do âmbito de abrangência de critério, seja do antecedente, seja do consequente da norma jurídica tributária, que impede que o tributo nasça. São suas as seguintes palavras:

Guardando a sua autonomia normativa, a regra de isenção investe contra um ou mais dos critérios da norma-padrão de incidência, mutilando-os, parcialmente. É óbvio que não pode haver supressão total do critério, porquanto equivaleria a destruir a regra matriz, inutilizando-a como norma válida no sistema. O que o preceito de isenção faz é subtrair parcela do campo de abrangência do critério do antecedente ou do conseqüente. Vejamos um modelo: estão isentos do imposto sobre a renda e proventos de qualquer natureza os rendimentos do trabalho assalariado dos servidores diplomáticos de governos estrangeiros. É fácil notar que a norma jurídica de isenção do IR (pessoa física) vai de encontro à regra-matriz de incidência daquele imposto, alcançando-lhe o critério pessoal do conseqüente, no ponto exato do sujeito passivo. Mas não o exclui totalmente, subtraindo, apenas, no domínio dos possíveis sujeitos passivos, o subdomínio dos servidores diplomáticos de governos estrangeiros, e mesmo assim quanto aos rendimentos do trabalho assalariado. Houve uma diminuição do universo dos sujeitos passivos, que ficou desfalcado de uma pequena subclasse ${ }^{103}$.

Ou seja, para que ocorra o fenômeno da isenção, mister faz-se haver o encontro de duas normas jurídicas. A primeira, que trata da regra-matriz de incidência (norma de comportamento) sofre a influência da segunda, que trata da supressão parcial de um ou mais dos critérios do antecedente ou do consequente (norma de estrutura), de modo que o campo de abrangência da regra matriz é limitado pela norma isentiva.

\footnotetext{
102 "Art. 176. A isenção, ainda quando prevista em contrato, é sempre decorrente de lei que especifique as condições e requisitos exigidos para a sua concessão, os tributos a que se aplica e, sendo caso, o prazo de sua duração.

Parágrafo único. A isenção pode ser restrita a determinada região do território da entidade tributante, em função de condições a ela peculiares".

${ }^{103}$ CARVALHO, Paulo de Barros. Curso de Direito Tributário. 26. ed. São Paulo: Saraiva, 2014. p. 568-569.
} 
Diferentemente do que ocorre no tocante às imunidades tributárias, as quais são interpretadas de forma ampliativa, as isenções são interpretadas de forma restritiva, de acordo com o preceito contido no artigo 111 do Código Tributário Nacional ${ }^{104}$.

Por fim, mas não menos importante, cumpre-nos conceituar "não incidência". Para tanto, mister faz-se discorrer acerca do fenômeno da incidência tributária. Como sabido, o sistema jurídico brasileiro é formado por inúmeras espécies de normas, dentre as quais as gerais e abstratas e as individuais e concretas.

As normas gerais e abstratas contemplam no seu antecedente um acontecimento futuro e desprovido de qualquer concretude em relação a sua ocorrência em determinado espaço e em específico tempo. Em virtude da generalidade e da abstração das normas gerais e abstratas, elas não atuam diretamente sobre as condutas intersubjetivas.

Sobre as condutas intersubjetivas atuam as normas individuais e concretas. Para que o direito seja aplicado, necessário faz-se que haja a incidência da norma sobre cada situação específica. Dessa forma, falar em aplicação é o mesmo que falar em incidência, porquanto a norma jurídica não incide sozinha.

Assim, para que a norma jurídica incida e, consequentemente, seja aplicada, ou seja, para que seja construída a norma individual e concreta, necessária faz-se a presença de um ente competente, isto é, uma pessoa que o próprio sistema elege como apta para, com base em normas gerais e abstratas, produzir normas individuais e concretas.

Dessa forma, o agente competente, por intermédio dos instrumentos que o sistema disponibiliza-lhe, verificando a ocorrência no mundo fenomênico do evento descrito no antecedente da regra-matriz de incidência tributária, reduzirá tal acontecimento em linguagem competente. Por meio da operação lógica denominada incidência, instaurará a relação jurídica tributária através da qual o sujeito ativo (Fisco) possui o direito subjetivo de perceber determinada quantia a título de tributo e, o sujeito passivo (contribuinte/responsável), o dever jurídico de desfazer de parcela de seu patrimônio visando ao pagamento desse mesmo tributo.

Assim, entende-se por incidência a operação lógica por meio da qual, ocorrido o evento previsto na norma geral e abstrata, e desde que vertido em linguagem adequada pela autoridade competente, origina-se uma norma individual e concreta estabelecendo os deveres e direitos dos sujeitos componentes desse mesmo liame jurídico.

\footnotetext{
104 “Art. 111. Interpreta-se literalmente a legislação tributária que disponha sobre:

I - suspensão ou exclusão do crédito tributário;

II - outorga de isenção;

III - dispensa do cumprimento de obrigações tributárias acessórias."
} 
Em outras palavras, dá-se o fenômeno da incidência tributária da seguinte forma: a norma geral e abstrata, que é fundamento de validade para a norma individual e concreta, estabelece em sua regra-matriz de incidência tributária os critérios componentes do antecedente (critérios material, espacial e temporal) e do consequente (critérios pessoal e quantitativo). Ocorrido o evento (acontecimento do mundo social) descrito no antecedente da norma geral e abstrata, estabelece-se, por meio da linguagem competente, uma norma individual e concreta tendo como valência um dos modais deônticos proibido $(\mathrm{V})$, permitido (P) ou obrigatório (O). É, inclusive, a partir desse momento que surge o fato jurídico.

Portanto, para que se dê a incidência e a consequente instauração da relação jurídica entre Fisco e contribuinte, faz-se indispensável que o acontecimento do mundo social descrito no antecedente da norma jurídica seja vertido em linguagem competente, fazendo nascer, a partir desse momento, a relação jurídica de cunho tributário.

Se, em linhas gerais, incidência é a situação contemplada pelo legislador na norma geral e abstrata a qual, vertida em linguagem competente, instaura o vínculo jurídico entre Fisco e contribuinte, entende-se por não incidência justamente o inverso: a situação não contemplada pelo legislador no momento da descrição dos eventos componentes do antecedente da regra-matriz de incidência tributária.

Veja-se, nesse sentido ${ }^{105}$, o entendimento de Gilberto Ulhôa Canto:

Outra figura que pode levar a consequências econômico-financeiras idênticas às da isenção é a não incidência. Nesta o imposto não é devido porque a pessoa ou o ato, fato ou situação que a respectiva lei instituidora previu como necessário e suficiente à ocorrência do fato gerador está fora do conceito que deste a própria lei enuncia. Como não se trata de situação em que, segundo a lei, possa surgir a obrigação tributária, é óbvio que a inexigibilidade de imposto é uma consequência lógica dessa circunstância, não sendo necessário que se a declare de modo expresso ${ }^{106}$.

Do confronto entre o que foi dito em relação à "imunidade", à "isenção" e à "não incidência", conclui-se, de forma clara e objetiva, que:

1. As regras de imunidade representam normas de estrutura, expressamente contidas na Constituição Federal de 1988, que se prestam a delimitar a competência

\footnotetext{
105 Luís Eduardo Schoueri também comunga desse posicionamento. Vide, nesse sentido: SCHOUERI, Luís Eduardo. Direito Tributário. 2. ed. São Paulo: Saraiva, 2012. p. 224.

${ }^{106}$ CANTO, Gilberto de Ulhôa. Imunidade Tributária - Entidades Fechadas de Previdência Privada (Fundos de Pensão). In: Revista de Direito Tributário n. 61. São Paulo: Malheiros, 1994. p. 20.
} 
impositiva tributária da União, Estados, Distrito Federal e Municípios, estabelecendo as situações, pessoas ou coisas sobre as quais não há que se falar em imposição tributária;

2. As regras isentivas possuem por objetivo suprimir, de forma parcial, um ou mais critérios do antecedente ou do consequente da regra-matriz de incidência tributária;

3. Entende-se por "não incidência" as situações, pessoas ou coisas não contempladas pelo legislador como passíveis de sofrer a incidência dos tributos a que a Constituição Federal de 1988 faz alusão;

4. As normas que tratam da imunidade devem estar dispostas, necessariamente, no texto constitucional, ao passo que as normas isentivas só podem ser tratadas via lei, seja complementar, seja ordinária;

5. As imunidades tributárias são interpretadas de forma extensiva, enquanto as regras de isenção o são de maneira restritiva.

\subsection{Imunidade Tributária: valor versus limite objetivo}

Outra questão discutida na doutrina diz respeito à caracterização da norma jurídica ${ }^{107}$ levando em conta a sua intensidade. As normas jurídicas estão carregadas de valor ${ }^{108}$, o qual pode apresentar-se em diferentes intensidades, variando de uma norma para outra.

Tais valores podem ser considerados

a) como norma jurídica de posição privilegiada e portadora de valor expressivo; b) como norma jurídica de posição privilegiada que estipula limites objetivos; c) como os valores insertos [sic] em regras jurídicas de posição privilegiada, mas considerados independentemente das estruturas

\footnotetext{
107 Em decorrência de a expressão "norma jurídica" ser ambígua, já que pode possuir diversas acepções, adotaremos, neste trabalho científico, o entendimento de que "norma jurídica" é a significação extraída a partir da leitura e análise dos textos que compõem o direito positivo, de acordo com as lições de Paulo de Barros Carvalho: "Norma jurídica é uma estrutura categorial, construída epistemologicamente, pelo intérprete, a partir das significações que a leitura dos documentos do direito positivo desperta em seu espírito. É por isto, que, quase sempre, não coincidem com os sentidos imediatos dos enunciados em que o legislador distribui a matéria no corpo físico da lei. Provém daí que, na maioria das vezes, a leitura de um único artigo será suficiente para a compreensão da regra jurídica. E, quando isto acontecer, o exegeta vê-se na contingência de consultar outros preceitos do mesmo diploma e, até, a sair dele, fazendo incursões pelo sistema." (CARVALHO, Paulo de Barros. Direito tributário: fundamentos jurídicos da incidência. São Paulo: Saraiva, 2008. p. 69).

${ }^{108}$ É justamente por este motivo que Paulo de Barros Carvalho menciona que "não é exagero referir que o dado valorativo está presente em toda configuração do jurídico, desde seus aspectos formais (lógicos), como nos planos semântico e pragmático. Em outras palavras, ali onde houver direito, haverá, certamente, o elemento axiológico." (CARVALHO, Paulo de Barros. Direito Tributário Linguagem e Método. São Paulo: Noeses, 2009. p. 174).
} 
normativas; e d) como o limite objetivo estipulado em regra de forte hierarquia, tomado, porém, sem levar em conta a estrutura da norma ${ }^{109}$.

Tendo em vista as feições que o valor pode tomar, cumpre-nos avaliar se as normas jurídicas que tratam das imunidades encerram tão somente um valor considerado em si mesmo ou um limite objetivo.

Tal distinção é deveras importante, tanto do ponto de vista teórico quanto sob o prisma pragmático uma vez que, se considerarmos que as imunidades tributárias encerram um limite objetivo, somente serão consideradas imunes as situações, pessoas ou coisas explicitamente excluídas do campo de atuação dos entes tributantes. Porém, se concluirmos que as imunidades tributárias encerram tão somente valores em si mesmos, poder-se-á chegar à conclusão de que as hipóteses descritas na Carta Magna como impassíveis de tributação por estarem cobertas pelo manto da imunidade tributária são desnecessárias. Tal posicionamento é justificado já que, por meio da aplicação de determinados e específicos princípios constitucionais tributários, os entes políticos estariam impedidos de exigir o recolhimento dos tributos descritos na Constituição Federal de 1988.

A fim de responder a esse questionamento, cumpre-nos mencionar as principais diferenças entre valores e limite objetivo.

Miguel Reale, desprendendo os valores dos objetos ideais, erigiu a Teoria dos Valores à categoria autônoma. Segundo esse autor, a fim de vislumbrarmos a presença de valores, é preciso identificar os traços que lhe são peculiares. São eles ${ }^{110}$ :

1. Bipolaridade: todo o valor se contrapõe a um desvalor, de modo que o sentido de um exige o do outro. Dessa forma, onde houver o valor haverá, necessariamente, um desvalor. Como exemplo, podemos mencionar o adjetivo bonito (valor), cujo desvalor corresponde ao adjetivo feio;

2. Implicação recíproca: nenhum valor se realiza sem influenciar, direta ou indiretamente, na realização dos demais. Por exemplo: o certo implica o justo que, por sua vez, implica a liberdade;

3. Referibilidade: o valor decorre sempre da tomada de posição de alguém em relação a algo. É por esse motivo que Paulo de Barros Carvalho menciona que os valores "valem" e não "são"111;

\footnotetext{
${ }^{109}$ CARVALHO, Paulo de Barros Carvalho. Curso de Direito Tributário. 26. ed. São Paulo: Saraiva, 2014. p. 192.

${ }^{110}$ REALE, Miguel apud CARVALHO, Paulo de Barros Carvalho. Curso de Direito Tributário. 26. ed. São Paulo: Saraiva, 2014. p. 192.
} 
4. Preferibilidade: o valor, por demonstrar uma tomada de posição em relação ao objeto (referibilidade), aponta a direção para a qual o intérprete quer “seguir". Isto é, o valor que atribuímos a um objeto é justamente aquele que preferimos dentre outros valores aplicáveis;

5. Incomensurabilidade: significa dizer que os valores não podem ser medidos, mensurados;

6. Graduação hierárquica: em razão de determinado valor ser escolhido em certa ocasião (aplicação do elemento preferibilidade), o agente teve de favorecer o escolhido em detrimento dos outros, de acordo com sua ideologia. Por isso se diz que os valores tendem a possuir uma ordem escalonada de preferência por parte do agente;

7. Objetividade: os valores configuram-se como qualidades que os serem humanos predicam a objetos;

8. Historicidade: os valores são construídos por meio da evolução do processo histórico social. Como menciona Paulo de Barros Carvalho, "os valores não caem do céu, mas vão sendo depositados, gradativamente, ao longo da trajetória existencial dos homens"112;

9. Inexauribilidade: o valor nunca se esgota, poisjamais se aplica a um único objeto, mas sim a vários e de forma infinita;

10. Atributividade: ato por meio do qual o agente atribui (por intermédio da valoração) determinado valor a determinado objeto; e

11. Indefinibilidade: os valores são indefiníveis, já que não carregam nenhuma ideia que os antecede.

No que diz respeito ao limite objetivo, nenhum desses elementos encontra-se presente, já que sua constatação é muito mais simples, direta e imediata e não requer maiores construções interpretativas. Basta analisar o suporte físico e, constatada a existência de regra $^{113}$ específica sobre determinado assunto, lá estará ele, limite objetivo, presente.

${ }^{111}$ CARVALHO, Paulo de Barros. Direito Tributário Linguagem e Método. São Paulo: Noeses, 2009. p. 176.

112 CARVALHO, op. cit., p. 178.

113 É importante aqui mencionar a existência de distinção entre regra e princípio. Entende-se por princípios os preceitos carregados de valor e que, em função de seu papel sintático, exercem grande influência sobre extensas porções do ordenamento jurídico, informando o vetor de sua compreensão. Para Paulo Ayres Barreto, "princípios são enunciados prescritivos, dotados de elevada carga axiológica, que informam a produção legislativa (normas de estrutura) e a compostura das normas jurídicas reguladoras de condutas intersubjetivas (normas de conduta). Parâmetros lógicos e axiológicos estarão sempre presentes na apreciação de conflitos normativos." (Contribuições: regime jurídico, destinação e controle. 2. ed. São Paulo: Noeses, 2011. p. 16.). As regras podem, por escopo, pré-demarcar o campo de atuação estatal, por meio de descrição de comportamentos 
A fim de demonstrar a facilidade com que um limite objetivo pode ser constatado no ordenamento jurídico brasileiro, daremos voz às considerações de Paulo de Barros Carvalho ao ponderar sobre o princípio da anterioridade como um limite objetivo:

\begin{abstract}
A diretriz da anterioridade, com toda a força de sua presença na sistemática impositiva brasileira, é um "limite objetivo". Sua comprovação em linguagem competente (a linguagem das provas admitidas em direito) é de uma simplicidade franciscana: basta exibir o documento oficial relativo ao veículo que introduziu normas jurídicas no sistema de direito positivo, com a comprovação do momento em que se tornou de conhecimento público, e poderemos saber, imediatamente, se houve ou não respeito ao princípio da anterioridade. E, por igual, a legalidade. Se o tributo foi introduzido por ato infralegal, o que se prova com facilidade, ficaremos seguros de que o princípio foi violado. ${ }^{114}$
\end{abstract}

Não obstante a fácil verificação de um limite objetivo em detrimento dos valores, tais regras objetivam atender específicos valores. Ele, limite objetivo, volta-se para a realização de valores, de forma indireta ou mediata ${ }^{115}$. Por este motivo, pode-se dizer que o limite objetivo é iluminado pelo valor.

Assim, visando a proteger determinado valor extremamente caro à sociedade, pode o legislador constituinte inserir uma regra na Constituição Federal tendo como propósito garantir e proteger tal valor.

É justamente o que ocorre com as imunidades tributárias, já que foram concebidas para resguardar valores considerados como de superior interesse nacional, tais como a manutenção das entidades federadas, o exercício das atividades religiosas, da democracia, das instituições educacionais, assistenciais e beneficentes e o acesso à informação e à cultura.

Dessa forma, por meio do instrumento denominado imunidade tributária, o legislador constituinte tem a pretensão de positivar determinados valores caros à sociedade e ao Estado Democrático de Direito.

obrigatórios, permitidos ou proibidos. As regras selecionam os acontecimentos do mundo social que deverão ser juridicizados. Elas instituem deveres definitivos (deveres que não podem ser superados por razões contrárias) e são aplicadas por meio da subsunção.

${ }^{114}$ CARVALHO, op. cit., p. 196.

115 Nesse sentido já se manifestou Fabiana Del Padre Tomé: "Embora os limites objetivos, diversamente dos valores, possam ser verificados com facilidade, sendo susceptíveis de comprovação, estes visam a atingir valores. Os limites-objetivos postos pelo ordenamento não são valores, se os considerarmos em si mesmos, mas voltam-se para realizar valores, de forma indireta, mediata.

Efetuada a digressão supra, conclui-se que as imunidades configuram 'limites-objetivos', pois embora caracterizem regras objetivas, visam à realização de determinados valores.[...]” (TOMÉ, Fabiana Del Padre. Alcance da imunidade das receitas de exportação (art. 149, § 2 $2^{\circ}$, I, da Constituição): a Questão da Contribuição Social sobre o Lucro Líquido - CSLL. In: COÊLHO, Sacha Calmon Navarro (Org.). Contribuições para Seguridade Social. Vol. 1. São Paulo: Quartier Latin, 2007. p. 319-336. p. 328. 
Deveras, por possuírem essa feição de limite objetivo, as normas jurídicas que tratam das imunidades tributárias encerram comandos específicos e diretos endereçados ao legislador infraconstitucional. Ou seja, o legislador infraconstitucional não possui qualquer espécie de liberdade para estabelecer regras de comportamento com o intento de tributar as pessoas, situações ou coisas expressamente excluídas do seu campo de atuação arrecadatória, mesmo que tais regras venham de encontro a valores morais seus. Ele deverá ater-se às hipóteses taxativamente descritas no texto constitucional.

Em outras palavras, o campo de autuação do legislador infraconstitucional já está demarcado pelo legislador constitucional - o qual, repise-se, já traçou e elencou todos os acontecimentos do mundo social sobre os quais não poderá haver a incidência tributária.

Pretendendo robustecer a ideia ora tratada, transcrevemos as lições de Paulo de Barros Carvalho que, ao destrinchar o conceito de imunidade tributária por ele formulado, menciona, expressamente, que as hipóteses dessa espécie de exoneração devem estar explicitadas no texto constitucional:

A cláusula é relevante para demonstrar que as imunidades tributárias são somente aquelas explicitadas na Carta Magna, compondo um grupo de elementos que, a qualquer momento, pode ser determinado nas suas várias unidades. A finitude é traço diferencial importante, se levarmos em conta a infinitude própria das proibições implícitas. ${ }^{116}$

Contudo, esse entendimento não é pacífico. Existem inúmeras e respeitadas vozes ${ }^{117}$ dentro do universo do direito tributário que entendem que a imunidade tributária não pode ser considerada um limite objetivo, de modo que as hipóteses de imunidades descritas no texto constitucional são dispensáveis, porquanto por meio da aplicação de determinados e específicos princípios constitucionais tributários se atinge o mesmo resultado das hipóteses descritas no texto constitucional: impedir que os entes políticos exerçam sua competência tributária sobre determinadas situações, pessoas ou coisas.

Por todos, transcrevemos o entendimento de Luís Eduardo Schoueri:

\footnotetext{
116 CARVALHO, Paulo de Barros. Imunidade Tributária. In: Direito Tributário Linguagem e Método. São Paulo: Noeses, 2009. p. 306-355. (p. 341).

${ }^{117}$ Dentre os seguidores da corrente que entende que as imunidades tributárias encerram autêntico princípio e não uma regra, podemos citar Luís Eduardo Schoeuri (Imunidade tributária e ordem econômica. In: Valdir de Oliveira Rocha (Coord.). Grandes Questões Atuais do Direito Tributário. São Paulo: Dialética, 2011. p. 229-241 (p. 231), Bernardo Ribeiro Moraes (A imunidade tributária e seus novos aspectos. Revista Dialética de Direito Tributário, São Paulo, n. 34, p. 22), Roque Antonio Carraza (Curso de Direito Constitucional Tributário. 29. ed. São Paulo: Malheiros, 2013. p. 825), Misabel Abreu Machado Derzi (Limitações Constitucionais ao Poder de Tributar. 8. ed. Rio de Janeiro: Forense, 2010. p. 31).
} 
Assim é que não cabe referir à imunidade citando apenas um dispositivo. Poder-se-á, claro, mencionar aquele trecho em que se evidencia a imunidade; a norma, entretanto, será objeto de construção mais complexa, exigindo que se combinem diversos dispositivos do próprio texto constitucional ou de outros enunciados normativos - em especial, no caso da imunidade, a lei complementar - resultando daí o sentido do mandamento constitucional.

A partir de tal premissa, torna-se possível constatar que as imunidades contam com uma série de dispositivos constitucionais que interagem em direção idêntica, implicando um alargamento de seu alcance. São casos em que mesmo que inexistisse enunciado expresso versando sobre a limitação ao poder de tributar, outros dispositivos constitucionais já seriam suficientes para indicar o desiderato constitucional.

Conforme se verifica no trecho acima, Schoueri entende que os dispositivos da Constituição Federal que tratam da imunidade tributária são desnecessários, dado que seria plenamente possível, dentro de nossa ordem constitucional, não haver a tributação de determinadas pessoas, situações ou coisas levando-se em conta somente determinados valores constitucionalmente protegidos.

Esse, todavia, não é o nosso entendimento.

Isso porque a Constituição Federal de 1988, por ser extremamente rígida, discriminou a competência tributária de cada um dos entes políticos, estabelecendo quais normas positivas (instituidoras dos tributos elencados na $\mathrm{CF}$ ) poderiam ser expedidas e quais situações, coisas ou pessoas não poderiam ser alcançadas por tais normas positivas.

Se o legislador constituinte original, ao externar seu juízo valorativo, pinçou acontecimentos específicos do mundo fenomênico que não poderiam ser objeto de tributação e os incluiu no texto constitucional, comprovada está a condição de limite objetivo das imunidades tributárias, pois houve a pré-demarcação do campo de atuação estatal por meio de descrição de comportamentos obrigatórios, permitidos ou proibidos.

Nesse sentido, veja-se a manifestação de Paulo Ayres Barreto:

Consciente de que, quanto mais aberto for o conteúdo normativo, mais difícil será o seu controle e, consequentemente, menos eficaz a dicção constitucional, o legislador constituinte de 1988 cunhou Texto Constitucional que estabelece os princípios estruturantes do nosso sistema jurídico, e que fixa uma séria de regras delimitadoras do sentido e do alcance desses princípios, a fim de permitir um maior controle dos fins almejados. Quisesse trilhar caminho diverso, teria o legislador constituinte de 88 optado por Carta de caráter puramente principiológico, em relação à qual só haveria conflitos ou colisões entre normas de diferentes hierarquias. Não foi esse o caminho escolhido. Como corolário, entendemos ser de fundamental importância, em face da atual Carta Constitucional, reconhecer que os 
princípios positivados estão submetidos às regras insertas no mesmo Texto, que lhe darão feição mais específica, permitindo um melhor controle de sua realização.

Nesse contexto, os princípios que encerram limites objetivos, como, por exemplo, o da anterioridade, refletem, verdadeiramente, a decisão do legislador constituinte de regrar, com maior objetividade, um mandamento, em detrimento de uma prescrição mais aberta, principiológica, como seria o princípio da não surpresa ou da própria segurança jurídica. ${ }^{118}$

Apesar de o trecho acima transcrito, extraído da obra "Contribuições Regime Jurídico, Destinação e Controle" de Paulo Ayres Barreto, não tratar especificamente da condição de limite objetivo das imunidades tributárias, ele se aplica, em sua totalidade, a elas. Porquanto, se o legislador constituinte pretendeu editar uma Constituição Federal rígida sem dar muita margem ao legislador infraconstitucional para editar as normas jurídicas de sua competência, é forçoso reconhecer a mesma rigidez em relação às situações sobre as quais o mesmo legislador infraconstitucional está impedido de estender o manto tributário.

Nesse mesmo sentido manifestou-se Eurico Marcos Diniz de Santi, para quem as imunidades tributárias configuram-se como legítimos limites objetivos:

$\mathrm{O}$ valor que informa a regra objetiva-se e esgota-se na própria regra. Ora, o fato de o direito à vida informar a regra do homicídio não implica que uma circunstância qualquer que afronte o direito à vida seja homicídio. Fosse assim, não teria utilidade em esculpir o tipo expressamente previsto no artigo 121 do Código Penal. Tampouco o esforço de descrever, expressamente, as imunidades no artigo 150 da Constituição Federal de 1988.

Daí a distinção essencial, efetivada por Paulo de Barros Carvalho, entre "valores" e "limites objetivos". Bipolaridade, implicação recíproca, referibilidade, preferibilidade, graduação hierárquica, necessidade de aderência a um objeto (objetividade), historicidade e inexauribilidade são os traços que permitem identificar um valor. Em contraste com os valores, os limites objetivos são regras objetivas postas para atingir certos fins. Estes, sim, assumem o porte de valores. ${ }^{119}$

Destarte, entendemos que as imunidades tributárias encerram verdadeiros limites objetivos. Deste modo, fora do campo delimitado pelos artigos da Constituição Federal de 1988 em que estão demarcadas, expressamente, quais são as situações, coisas ou pessoas que não poderão sofrer a exigência de determinados tributos discriminados no texto magno, não se poderá falar em existência de imunidade tributária.

\footnotetext{
118 Ob. cit., p. 20.

119 SANTI, Eurico Marcos Diniz de. Imunidade tributária como limite-objetivo e as diferenças entre "livro" e "livro eletrônico". MACHADO, Hugo de Brito (org.). In: Imunidade tributária do livro eletrônico. 2. ed. São Paulo: Malheiros, 2003. p. 62.
} 


\subsection{Relação entre Imunidade Tributária e Cláusula Pétrea}

\section{Consoante aduzido previamente, o sistema constitucional brasileiro é extremamente} rígido. É um dos sistemas mais austeros dentre os países federalistas.

A esse propósito, vejam-se as considerações de Paulo Ayres Barreto:

O sistema passível de ser erigido a partir da Constituição de 88 dista de ser sintético ou genérico. Não se caracteriza pela plasticidade. Ao revés, nossa Constituição é rígida. Cuida de talhar, minudentemente, diversos subsistemas, dentre eles o tributário. Com efeito, não há sistema constitucional que se assemelhe ao nosso, na extensividade no trato da matéria tributária. Tal opção legislativa, já de longa tradição no Brasil, produz relevantes efeitos jurídicos. Gostemos ou não dela, é forçoso reconhecer que foi o caminho escolhido pelo legislador constituinte. Em consequência, a aproximação que o intérprete haverá de fazer ao direito posto terá não apenas como ponto de partida a Constituição Federal; mais do que isso, exigir-se-á um longo e espinhoso trabalho exegético, realizado exclusivamente nesse plano constitucional, para então se perquirir sobre o conteúdo dos comandos normativos infraconstitucionais. ${ }^{120}$

Uma Constituição é rígida quando para sua modificação impõe-se um processo complexo e mais complicado do que aquele contemplado para a elaboração de uma norma jurídica infraconstitucional $^{121}$. Em virtude dessa severidade constitucional, vige em nosso

\footnotetext{
${ }^{120}$ BARRETO, Paulo Ayres. Contribuições: regime jurídico, destinação e controle. São Paulo: Noeses, 2011. p. 28.

${ }^{121}$ De acordo com os constitucionalistas, a Constituição pode sofrer alterações do ponto de vista formal e sob o prisma informal. Sob o aspecto formal, a Constituição Federal pode sofrer modificação por meio de Emenda Constitucional ou por intermédio de revisão constitucional. Sob o prisma informal, a Constituição Federal pode sofrer alteração por intervenção da denominada mutação constitucional. A mutação constitucional consiste em uma modificação na significação extraída ou construída a partir do texto constitucional (suporte físico), no processo de interpretação do direito. Por sua vez, a modificação formal da Constituição Federal de 1988 pode se dar de duas formas: por meio da edição de Revisão Constitucional e por intermédio da edição de Emenda Constitucional. De acordo com o artigo $3^{\circ}$, do Ato das Disposições Constitucionais Transitórias (ADCT), a revisão constitucional seria realizada após cinco anos da promulgação da Carta Magna de 1988. Foi justamente o que ocorreu em outubro de 1993. Nessa oportunidade a população brasileira optou por manter o regime republicano, rejeitando, dessa forma, a proposta de instituição de monarquia constitucional, bem como o sistema presidencialista de governo, em detrimento da tentativa de instauração de um sistema parlamentarista. Com a manutenção do regime republicano e do sistema presidencialista, a questão da revisão constitucional perdeu sua finalidade. Tendo em vista que a Constituição Federal elencou a possibilidade de análise de revisão constitucional uma única vez, não é possível que ocorra a revisão constitucional, a menos que, por meio de Emenda Constitucional, tal previsão seja incluída. Por sua vez, no que concerne à edição de Emenda Constitucional, para que tal normativo possa ser editado, é preciso observar a dicção contida no artigo 60 da Constituição Federal de 1988. Nos termos desse artigo, a proposta de Emenda Constitucional pode ser efetuada por um terço, no mínimo, dos membros da Câmara dos Deputados ou do Senado Federal; pelo Presidente da República; e por mais da metade das Assembleias Legislativas das unidades da Federação. Além da observância dos requisitos de ordem formal, faz-se necessário atentar aos pressupostos de ordem material a que a Constituição Federal faz alusão, para fins de edição de Emenda Constitucional. De acordo com o artigo 60, $\S 4^{\circ}$, da Constituição Federal de 1988, não será objeto de deliberação a emenda tendente a abolir a forma federativa de
} 
ordenamento o princípio da reserva de lei constitucional ou, nas palavras de Regina Helena Costa, o "princípio da supremacia da Constituição". ${ }^{122}$

O instituto da "reserva de lei constitucional" foi "importado" do direito alemão que, em um primeiro momento, estabeleceu o conceito clássico de "reserva de lei" (Vorbehalt des Gesetzes), o qual possuía por objeto a proteção do cidadão contra as interferências dos órgãos de aplicação do Direito - Poder Executivo e Judiciário - na sua esfera de liberdade e propriedade (XAVIER, 2005, p. 197).

Em um segundo momento, a doutrina alemã começou a considerar a possibilidade de proteção dos cidadãos não mais só em relação às interferências dos Poderes Judiciário e Executivo, mas também às do Poder Legislativo. Diante disso, o conceito de "reserva de lei" sofreu mutação e passou a proteger, inclusive, os cidadãos das interferências do Poder Legislativo, no que se denominou de "reserva de Constituição".

Por meio da "reserva de Constituição", o legislador constituinte se reservou ao direito de estabelecer determinadas matérias que só podem ser objeto de normas de cunho constitucional. Dentre essas espécies de normas, enquadram-se as que tratam dos direitos e garantias fundamentais dos cidadãos.

Sobre a questão da "reserva de Constituição", Alberto Xavier assim se manifestou:

Com efeito, enquanto o conceito clássico de "reserva de lei" (Vorbehalt des Gesetzes) tinha em vista a proteção do cidadão contra as interferências dos órgãos de aplicação do Direito - o Poder Executivo e o Poder Judiciário - na sua esfera de liberdade e propriedade, o conceito moderno de "reserva de Constituição" ou "reserva de lei constitucional" (Verfassungsvorbehalt) está centrado sobre a proteção do cidadão contra a interferência dos próprios órgãos de produção do Direito - o Poder Legislativo - na esfera do seu centro de interesses vitais, os chamados direitos e garantias individuais.

A "reserva de Constituição" significa que o poder constituinte se reservou certas matérias, que apenas podem ser objeto de leis constitucionais normas primárias de produção jurídica - às quais compete exclusivamente a sua regulamentação. ${ }^{123}$

No ordenamento jurídico brasileiro atual, a figura da "reserva de Constituição" encontra-se estampada no artigo $60, \S 4^{\circ}$, da Constituição Federal de $1988^{124}$, o qual trata das

Estado; o voto direto, secreto, universal e periódico; a separação dos Poderes; e os direitos e garantias individuais.

${ }^{122}$ COSTA, Regina Helena. Imunidades Tributárias. 2. ed. rev. e atual. São Paulo: Malheiros, 2006. p. 66.

${ }^{123}$ XAVIER, Alberto. Princípios do processo administrativo e judicial tributário. Rio de Janeiro: Forense, 2005. p. 197.

124 “\$ $4^{\circ}$ - Não será objeto de deliberação a proposta de emenda tendente a abolir:

I - a forma federativa de Estado; 
cláusulas pétreas, ou seja, das normas jurídicas que não poderão ser objeto de alteração nem mesmo por meio de Emenda Constitucional.

Por representarem os valores básicos e fundamentais da Constituição, as cláusulas pétreas equivalem a determinadas matérias que não poderão ser alteradas pelo exercício da competência do poder constituinte derivado ${ }^{125}$. De fato, de sua modificação incorre a pena de mutação da própria identidade do texto constitucional. Dessa maneira, ao incluir tais dispositivos na Constituição Federal, o constituinte procura impedir que os valores integrativos do Estado Democrático de Direito sejam suprimidos em forma de legalidade. Trata-se, portanto, de um núcleo imodificável, o qual é consequência da rigidez constitucional e representa a supremacia da Constituição.

Oswaldo Aranha Bandeira de Mello aduz quanto à Constituição, em sua obra intitulada “Teoria das Constituições Rígidas”, que:

[...] quando nela se altere determinado preceito, é porque considera básico, consolidando o seu verdadeiro e próprio espírito: se o poder constituinte, que se seguir, mudá-lo - o que, aliás, pode fazer, em virtude de ser soberano - , não reforma a antiga Constituição, porquanto a transformação é considerada radical, consistindo na abolição dela e na substituição por outra, que será a nova Constituição, embora tudo mais tenha sido conservado. Se quiséssemos usar de uma comparação diríamos que dispositivo nestas condições se encontra em face da Constituição, com a alma em relação ao corpo, como o espírito vivificador em relação à matéria. ${ }^{126}$

As cláusulas pétreas surgiram no direito constitucional brasileiro com a Constituição de 1891 que, em seu artigo $90, \S 4^{\text {o127 }}$, estabelecia que não poderiam ser objeto de deliberação "projetos tendentes a abolir a forma republicano-federativa, ou a igualdade da representação dos Estados no Senado".

II - o voto direto, secreto, universal e periódico;

III - a separação dos Poderes;

IV - os direitos e garantias individuais."

${ }^{125}$ Entende-se por poder constituinte derivado o poder instituído na Constituição para o fim de proceder à sua reforma; em contrapartida, entende-se por poder constituinte originário o poder que cria uma nova Constituição, ou seja, o poder que põe em vigor uma nova Constituição, seja de maneira propriamente originária (primeira Constituição de um país), seja derrubando o ordenamento jurídico constitucional anterior para instituir uma nova Constituição.

${ }^{126}$ MELLO, Oswaldo Aranha Bandeira de. Teoria das Constituições rígidas. 2. ed. São Paulo: José Bushatsky, 1980. p. 47.

127 “Art 90 - A Constituição poderá ser reformada, por iniciativa do Congresso Nacional ou das Assembléias dos Estados.

[...]

$\S 4^{\circ}$ - Não poderão ser admitidos como objeto de deliberação, no Congresso, projetos tendentes a abolir a forma republicano-federativa, ou a igualdade da representação dos Estados no Senado." 
As Cartas Políticas Federais posteriores também dispuseram acerca da existência de cláusulas pétreas. A Constituição da República dos Estados Unidos do Brasil de 1934 dispunha em seu artigo $178, \S 5^{\circ 128}$, que o texto constitucional não seria passível de reforma na hipótese de o projeto de alteração pretender "abolir a forma republicada federativa". Por seu turno, a Constituição dos Estados Unidos do Brasil de 1946 prescrevia em seu artigo 217, $\S 6^{\circ}$, não serem "admitidos como objeto de deliberação projetos tendentes a abolir a Federação ou a República”. A Constituição da República Federativa do Brasil de $1967^{129}$ e a Emenda Constitucional n. 1, de $1969^{130}$, mantendo a mesma redação da Constituição de 1946, também prescreviam não ser possível a edição de Emenda Constitucional tendente a abolir a Federação ou a República.

Feita essa incursão histórica pelas Constituições pretéritas, cumpre-nos retomar a análise da Carta Política de 1988.

De acordo com o artigo 60, $\S 4^{\circ}$ da Constituição Federal de 1988, não será objeto de deliberação a emenda tendente a abolir:
a) a forma federativa de Estado;
b) o voto direto, secreto, universal e periódico;
c) a separação dos Poderes; e
d) os direitos e garantias individuais.

Não existe muita dificuldade exegética em relação aos itens a), b) e c) acima mencionados. No entanto, não se pode dizer o mesmo em relação ao item d) - "direitos e garantias individuais".

A forma federativa de governo foi alçada pela Constituição Federal de 1988 à condição de viga mestra do sistema brasileiro.

O voto direto, secreto, universal e periódico, também possui garantia constitucional, de modo que a atividade de votar não poderá ser excluída do texto magno, sob pena de inconstitucionalidade. Como exemplo, cita-se a impossibilidade de edição de Emenda

\footnotetext{
128 “Art. 178 - A Constituição poderá ser emendada, quando as alterações propostas não modificarem a estrutura política do Estado (arts. 1 a 14, 17 a 21); a organização ou a competência dos poderes da soberania (Capítulos II III e IV, do Título I; o Capítulo V, do Titulo I; o Título II; o Título III; e os arts. 175, 177, 181, este mesmo art. 178); e revista, no caso contrário.

$[\ldots]$

$\S 5^{\circ}$ - Não serão admitidos como objeto de deliberação, projetos tendentes a abolir a forma republicana federativa."

129 “Art. 50 - A Constituição poderá ser emendada por proposta:

$\S 1^{\circ}$ - Não será objeto de deliberação a proposta de emenda tendente a abolir a Federação ou a República."

130 "Art 47 - A Constituição poderá ser emendada por proposta:

$\S 1^{\circ}$ - Não será objeto de deliberação a proposta de emenda tendente a abolir a Federação ou a República."
} 
Constitucional tendente a estabelecer que eleições para o cargo de Presidente da República ocorram a cada 50 anos.

O mesmo se dá em relação à separação dos três Poderes, a qual recebeu o status de “imutabilidade constitucional”. Não se admite a união, conjugação ou supremacia de um poder sobre o outro.

Por sua vez, no que tange aos direitos e garantias individuais, nos termos da melhor doutrina tais direitos e garantias estabelecem limites positivos ou negativos oponíveis a qualquer pessoa e mesmo ao Estado.

A esse respeito, Celso Antonio Bandeira de Mello fez os seguintes comentários:

Convém recordar que o Estado de Direito é a consagração jurídica de um projeto político. Nele se estratifica o objetivo de garantir ao cidadão contra intemperanças do Poder Público, mediante prévia subordinação do poder e de seus exercentes a um quadro normativo geral e abstrato cuja função precípua é conformar efetivamente a conduta estatal a certos parâmetros antecipadamente estabelecidos como forma de defesa dos indivíduos. ${ }^{131}$

Confira-se, outrossim, o entendimento de J. J. Gomes Canotilho:

[...] a função de direitos de defesa dos cidadãos sob uma dupla perspectiva: (1) constituem, num plano jurídico-objectivo, normas de competência negativa para os poderes públicos, proibindo fundamentalmente as ingerências destes na esfera jurídica individual; (2) implicam, num plano jurídico-subjectivo, o poder de exercer positivamente direitos fundamentais (liberdade positiva) e de exigir omissões dos poderes públicos, de forma a evitar agressões lesivas por parte dos mesmos (liberdade negativa). ${ }^{132}$

Para Carvalho, os direitos e garantias fundamentais são a

[...] somatória, harmônica e organizada dos mandamentos constitucionais sobre matéria tributária que, positiva ou negativamente, estipulam direitos, obrigações e deveres do sujeito passivo, diante das pretensões do Estado (aqui utilizado na sua acepção mais ampla e abrangente - entidade tributante). E quaisquer desses direitos, deveres e obrigações, porventura encontrados em outros níveis da escala jurídico-normativa, terão de achar respaldo de validade naqueles imperativos supremos, sob pena de flagrante injuridicidade. ${ }^{133}$

${ }^{131}$ MELLO, Celso Antônio Bandeira. Controle judicial dos atos administrativos. In: Revista de Direito Público. São Paulo, v. 153, 1986, p. 01.

${ }_{132}$ CANOTILHO, José Joaquim Gomes. Direito constitucional. Coimbra: Almedina, 1993. p. 541.

${ }^{133}$ CARVALHO. Paulo de Barros. Estatuto do contribuinte, direitos, garantias individuais em matéria tributária e limitações constitucionais nas relações entre Fisco e contribuinte. Vox-Legis, São Paulo, v. 141, n. 1, p. 36, 1978. 
Os direitos fundamentais representam um conjunto de direitos reconhecidos e garantidos pelo ordenamento jurídico de determinado país, os quais são limitados em virtude de seu caráter fundamentador do sistema jurídico próprio do Estado Democrático de Direito. Já as garantias fundamentais são os instrumentos fornecidos pela Constituição para fins de defesa e efetividade dos direitos dos cidadãos.

Os direitos e garantias fundamentais estão elencados no texto magno com o intuito de estabelecer e proteger os valores mais importantes de uma sociedade, tais como os relacionados à vida, à dignidade, à liberdade, à igualdade e à participação política.

Isso fica muito claro ao se analisar o preâmbulo da Carta Magna de 1988, que assim estabelece:

\begin{abstract}
Nós, representantes do povo brasileiro, reunidos em Assembléia Nacional Constituinte para instituir um Estado Democrático, destinado a assegurar o exercício dos direitos sociais e individuais, a liberdade, a segurança, o bemestar, o desenvolvimento, a igualdade e a justiça como valores supremos de uma sociedade fraterna, pluralista e sem preconceitos, fundada na harmonia social e comprometida, na ordem interna e internacional, com a solução pacífica das controvérsias, promulgamos, sob a proteção de Deus, a seguinte CONSTITUIÇÃO DA REPÚBLICA FEDERATIVA DO BRASIL.
\end{abstract}

José Afonso da Silva a propósito pontifica que

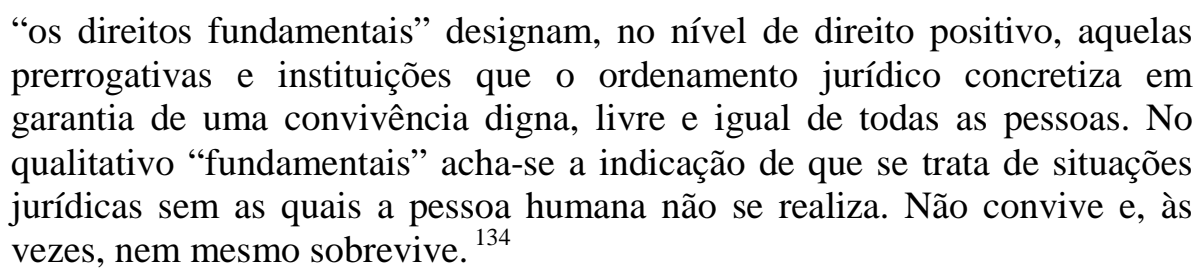

Os direitos fundamentais contidos na Constituição Federal de 1988 estão, via de regra, descritos no artigo $5^{\circ}$ da Constituição Federal. Desse extenso rol, faz-se imperativo destacar os que guardam relação, direta ou indiretamente, com o direito tributário. Como exemplo, podemos citar os seguintes:

a) caput do artigo $5^{\circ}$ : igualdade e segurança jurídica;

b) I - isonomia;

c) II - legalidade;

d) $\quad \mathrm{X}-$ inviolabilidade da privacidade;

e) XII - inviolabilidade do sigilo de dados;

${ }^{134}$ SILVA, José Afonso da. Curso de Direito Constitucional Positivo. São Paulo: Malheiros, 2006, p. 439. 
f) XXII - direito de propriedade;

g) XXXIII - direito ao recebimento de informações;

h) XXXIV - direito de petição;

i) $\quad \mathrm{XXXV}$ - inafastabilidade do controle judicial;

j) XXXVI - proteção do direito adquirido, ato jurídico perfeito e a coisa julgada;

k) LIII - juiz natural;

1) LIV - devido processo legal;

m) LV - ampla defesa;

n) LVI - impossibilidade de obtenção de provas por meios ilícitos;

o) LVII - presunção de inocência;

p) LX - publicidade dos atos processuais;

q) LXVII - proibição de prisão civil por dívidas;

r) LXIX - mandado de segurança;

s) LXX - mandado de segurança coletivo;

t) $\quad$ LXXI - mandado de injunção;

u) LXXII - habeas data;

v) LXXVII - gratuidade do habeas data;

w) LXXXIV - assistência judiciária gratuita;

x) LXXV - indenização por erro judiciário.

Os direitos e garantias constantes do artigo 5º da Constituição Federal de 1988 consubstanciam, em essência, valores e limites objetivos tendentes a salvaguardar liberdades individuais, consideradas valores supremos pela ordem constitucional.

É importante destacar que a enumeração do artigo $5^{\circ}$ não é taxativa. Além dos direitos e garantias dispostos nesse artigo, existem outros que se encontram em diversos outros dispositivos contidos na Carta Magna. Tanto é verdade que o $\S 2^{\circ}$ do artigo $5^{\circ}$ da Constituição Federal de 1988 prescreve que "os direitos e garantias expressos nesta Constituição não excluem outros decorrentes do regime e dos princípios por ela adotados, ou de tratados internacionais em que a República Federativa do Brasil seja parte". Em matéria tributária, o alcance da expressão "direitos e garantias individuais", via de regra, engloba quaisquer direitos e garantias constitucionais outorgados ao contribuinte. Mormente, pode-se mencionar aqueles constantes da Seção intitulada "Das Limitações Constitucionais ao Poder de Tributar" (artigos 150 a 152), além do artigo $5^{\circ}$ e outros dispositivos espalhados pelo texto 
constitucional (como, por exemplo, o artigo 170, da Constituição Federal ${ }^{135}$, que trata do direito à livre iniciativa).

Apesar de o presente trabalho científico estar restrito à imunidade tributária das entidades beneficentes de assistência social, no que diz respeito à relação entre imunidade e cláusula pétrea faremos uma análise um pouco mais abrangente, a fim de verificar quais das hipóteses descritas no artigo 150, inciso VI, da Constituição Federal de 1988 podem ser consideras cláusulas pétreas e, por via de consequência, impassíveis de serem limitadas ou suprimidas por meio do poder constitucional derivado.

O artigo 150 da Constituição Federal de 1988 estabelece que

sem prejuízo de outras garantias asseguradas aos contribuintes, é vedado à União, aos Estados, ao Distrito Federal e aos Municípios: [...] VI - instituir impostos sobre: a) patrimônio, renda ou serviços, uns dos outros; b) templos de qualquer culto; c) patrimônio, renda ou serviços dos partidos políticos, inclusive suas fundações, das entidades sindicais dos trabalhadores, das instituições de educação e de assistência social, sem fins lucrativos, atendidos os requisitos de lei.

Tal qual aludido em outras oportunidades ao longo do presente trabalho científico, as imunidades tributárias foram concebidas para preservar valores considerados como de superior interesse nacional, tais como a manutenção das entidades federadas, o exercício das atividades religiosas, da democracia, das instituições educacionais, assistencias e de filantropia e o acesso à informação e à cultura.

Por meio do artigo 150, inciso VI, alínea "a", a qual trata da "imunidade recíproca", a Constituição Federal pretendeu vedar, por parte dos entes políticos, a instituição de impostos

\footnotetext{
135 “Art. 170. A ordem econômica, fundada na valorização do trabalho humano e na livre iniciativa, tem por fim assegurar a todos existência digna, conforme os ditames da justiça social, observados os seguintes princípios:

I - soberania nacional;

II - propriedade privada;

III - função social da propriedade;

IV - livre concorrência;

$\mathrm{V}$ - defesa do consumidor;

VI - defesa do meio ambiente, inclusive mediante tratamento diferenciado conforme o impacto ambiental dos produtos e serviços e de seus processos de elaboração e prestação;

VII - redução das desigualdades regionais e sociais;

VIII - busca do pleno emprego;

IX - tratamento favorecido para as empresas de pequeno porte constituídas sob as leis brasileiras e que tenham sua sede e administração no País.

Parágrafo único. É assegurado a todos o livre exercício de qualquer atividade econômica, independentemente de autorização de órgãos públicos, salvo nos casos previstos em lei."
} 
sobre o patrimônio, rendas ou serviços uns dos outros. Buscou-se, por intermédio desse limite objetivo, preservar o pacto federativo e a autonomia das pessoas políticas.

Já o artigo 150, VI, “b”, veda a tributação de impostos sobre o "templo de qualquer culto". O valor que se buscou com essa regra foi o da liberdade religiosa e o da livre manifestação do pensamento, pretendendo impedir que a prática religiosa fosse obstruída via tributação.

O artigo 150, inciso VI, alínea "c", por seu turno, veda a tributação de "impostos sobre renda, patrimônio e serviços dos partidos políticos, inclusive suas fundações, das entidades sindicais dos trabalhadores e das instituições de educação e de assistência social, uma vez que sem fins lucrativos e atendidos os requisitos de lei”.

Os valores que os constituintes pretenderam abarcar no artigo 150, VI, "c" da Constituição Federal de 1988 foram os da liberdade de associação (artigo 5ª XVII), de entidades associativas (artigo $5^{\circ}, \mathrm{XXI}$ ), de associação profissional ou sindical (artigo $8^{\circ}$ ), de assistência aos necessitados e desassistidos $\left(\operatorname{artigo} 6^{\circ}\right)$ e de educação $\left(\operatorname{artigo} 6^{\circ}\right)$.

Ademais, o legislador constituinte, no artigo 150, VI, "d", proibiu a instituição de impostos sobre "livros, jornais, periódicos e o papel destinado a sua impressão". O valor perseguido pelo legislador nesse dispositivo foi o da liberdade de expressão (artigo $5^{\circ}$, IV) e o da manifestação de cultura e a vedação à censura (artigo $5^{\circ}$, IX). Por meio da imunidade dos livros, jornais e periódicos, pretendeu-se diminuir os custos com a produção desses veículos de comunicação, de modo a facilitar o acesso da população a eles e, consequentemente, difundir a cultura.

Por fim, mas não menos importante, cumpre-nos mencionar que, por meio da Emenda Constitucional n. 75, de 15 de outubro de 2013, incluiu-se no artigo 150, inciso VI, da Constituição Federal a alínea "e", que trata da imunidade tributária dos impostos relacionados a fonogramas e videofonogramas musicais, cujas espécies mais conhecidas são o CD (Compact Disc) e o DVD (Digital Versatile Disc), respectivamente.

O valor protegido por meio dessa mais recente espécie de imunidade genérica é o da manifestação da cultura nacional em detrimento da internacional. Afora tal proteção, pretende-se fortalecer a produção musical brasileira face à indústria da pirataria e da troca de arquivos por meio da Internet.

Dessa forma, em razão de a Constituição Federal de 1988 pretender preservar, por meio das imunidades tributárias genéricas, valores de superior interesse nacional e aplicáveis a toda a sociedade, sem exceção e sem a necessidade de edição de normas 
regulamentadoras ${ }^{136}$, é crucial reconhecer que essas normas que tratam da impossibilidade constitucionalmente conferida aos entes políticos de instituir tributos sobre determinadas situações, pessoas ou coisas, possuem a natureza de cláusulas pétreas, não podendo ser alteradas nem mesmo por intermédio de Emenda Constitucional.

Esse, inclusive, é o entendimento da grande maioria dos doutrinadores pátrios ${ }^{137}$. Representando a opinião de todos, cita-se Sacha Calmon Navarro Coêlho que assim se manifestou na época da realização do XXX Simpósio Nacional de Direito Tributário promovido pelo Instituto Geraldo Ataliba - IDEPE:

\section{AS LIMITAÇÕES CONSTITUCIONAIS AO PODER DE TRIBUTAR SÃO CLÁUSULAS PÉTREAS. ENTRE ELAS AS IMUNIDADES TRIBUTÁRIAS.}

A nosso ver, sim.

$[\ldots]$

Os princípios constitucionais tributários e as imunidades (vedações ao poder de tributar) traduzem reafirmações, expansões e garantias dos direitos fundamentais e do regime federal. São, portanto, cláusulas constitucionalmente perenes, pétreas, insuprimíveis (art. $60, \S 4^{\circ}$, da CF).

O Poder Judiciário pátrio, representado pela mais alta corte brasileira, o Supremo Tribunal Federal, já teve a oportunidade de manifestar-se acerca da condição de cláusula pétrea das imunidades tributárias descritas no artigo 150, inciso VI, da Constituição Federal de 1988:

Direito Constitucional e Tributário. Ação Direta de Inconstitucionalidade de Emenda Constitucional e de Lei Complementar. I.P.M.F. Imposto Provisório sobre a Movimentação ou a Transmissão de Valores e de Créditos e Direitos de Natureza Financeira - I.P.M.F. Artigos 5., par. 2., 60, par. 4., incisos I e IV, 150, incisos III, "b", e VI, "a", "b", "c" e "d", da Constituição Federal. [...]

2. A Emenda Constitucional n. 3, de 17.03.1993, que, no art. $2^{\circ}$, autorizou a União a instituir o I.P.M.F., incidiu em vício de inconstitucionalidade, ao dispor, no parágrafo 2 . desse dispositivo, que, quanto a tal tributo, não se aplica "o art. 150, III, "b" e VI", da Constituição, porque, desse modo, violou os seguintes princípios e normas imutáveis (somente eles, não outros): 1. - o princípio da anterioridade, que é garantia individual do contribuinte (art. 5., par. 2., art. 60, par. 4., inciso IV e art. 150, III, "b" da Constituição); 2. - o princípio da imunidade tributária recíproca (que veda a [sic] União, aos Estados, ao Distrito Federal e aos Municípios a instituição de impostos sobre o patrimônio, rendas ou serviços uns dos outros) e que e garantia da Federação (art. 60, par. 4., inciso I,e art. 150, VI, "a", da C.F.);

$[\ldots]$

\footnotetext{
${ }^{136}$ Em relação a essa questão, é importante mencionar que o artigo $5^{\circ}, \S 1^{\circ}$ da Carta Magna dispõe que "as normas definidoras dos direitos e garantias fundamentais têm aplicação imediata".

${ }^{137}$ Como exemplo, podemos citar Ives Gandra da Silva Martins, Ricardo Lobo Torres, Sacha Calmon Navarro Coêlho, José Eduardo Soares de Melo, os quais, ao participarem do XXX Simpósio Nacional de Direito Tributário, externaram suas opiniões no sentido de que as imunidades tributárias são cláusulas pétreas, de modo que elas não podem ser alteradas pelo poder constituinte derivado. Tais entendimentos fazem parte da obra intitulada Limitações ao poder impositivo e segurança jurídica, a qual teve como coordenador Ives Gandra da Silva Martins e foi lançada em 2005 pela editora Revista dos Tribunais.
} 
3. Em consequência, é inconstitucional, também, a Lei Complementar n. 77, de 13.07.1993, sem redução de textos, nos pontos em que determinou a incidência do tributo no mesmo ano (art. 28) e deixou de reconhecer as imunidades previstas no art. 150, VI, "a", "b", "c" e "d" da C.F. (arts. 3., 4. e 8. do mesmo diploma, L.C. n. 77/93).

$[\ldots] " .138$

Sendo assim, somente as imunidades tributárias mencionadas no artigo 150, inciso VI, alíneas "a", "b", “c" e "d" e mais recentemente na alínea "e", da Constituição Federal de 1988, podem ser contempladas com a cláusula de imutabilidade, por serem consideradas cláusulas pétreas já que as hipóteses descritas nesse dispositivo constitucional possuem alta carga axiológica, porquanto visam a preservar valores considerados como de superior interesse nacional, tais como a manutenção das entidades federadas, o exercício das atividades religiosas, da democracia, das instituições educacionais, assistenciais e de filantropia e o acesso à informação e à cultura.

Logo, as imunidades tributárias dos impostos descritas em outros dispositivos constitucionais que não o artigo 150, inciso VI, ${ }^{139}$ não estarão sob o manto da inalterabilidade, porquanto não se prestam a preservar valores considerados de interesse nacional, mas tão somente "garantias de não tributação aplicáveis a sujeitos ou situações"," nas palavras de Torres.

Para esse autor, somente as imunidades tributárias que servem como garantias materiais do federalismo e dos direitos fundamentais dos cidadãos podem ser consideradas cláusulas pétreas. As demais regras imunizantes, por possuírem a natureza de "simples limitação material", podem ser modificadas via Emenda Constitucional, único instrumento hábil a alterar o texto da Constituição de 1988:

As imunidades propriamente ditas são aquelas protegidas por cláusula pétrea (art. 60, IV, "b" e "d", da CF), por servirem como garantias materiais do federalismo e dos direitos fundamentais. Nessas modalidades, toda regra de imunidade, concentra sobre si intensa carga axiológica, ao acompanhar os valores constitucionalmente albergados em favor do federalismo (imunidade recíproca) ou dos direitos fundamentais. A atividade interpretativa dessas imunidades deve ser sobremodo coerente com tais valores, na busca do efetivo caráter teleológico que elas desejam preservar, como realização da

138 ADI 939, STF, Tribunal Pleno, Rel. Min. Sydney Sanches, DJ de 18/03/1994. Disponível em : <www.stj.jus.br>.Acesso em: 24 ago. 2014.

${ }^{140}$ TORRES, Heleno Taveira. Teoria da Norma de Imunidade Tributária e sua aplicação às entidades sem fins lucrativos. In: In: Direito tributário e ordem econômica: homenagem aos 60 anos da ABDF. São Paulo: Quartier Latin, 2010. p. 164-165. 
justiça, da liberdade ou da segurança, mediante aplicação que os reconheça com efetividade plena.

Ao lado destas encontram-se as imunidades impróprias, as quais, mesmo sendo regra de estrutura constitucional, determinantes de competências tributárias, não passam de uma simples limitação material, a ser apreciada nos limites técnicos de cada domínio de aplicação (ICMS, PIS/COFINS na exportação etc), não protegidas contra eventuais mudanças da Constituição, podendo vir a ser modificadas ou suprimidas a qualquer tempo, por serem garantias de não tributação aplicáveis a sujeitos ou situações, mas não na função de preservar direitos individuais ou o federalismo, como ocorre com imunidades propriamente ditas. ${ }^{141}$

Seguindo similar linha de raciocínio, Luís Eduardo Schoueri aduz que, via de regra, as imunidades tributárias visam a prestigiar as liberdades e garantias individuais, de modo que elas não poderiam ser alteradas, nem mesmo por Emenda à Constituição. Todavia, há casos em que o legislador constituinte originário não se preocupou em proteger determinado valor, tão somente mantendo a ordem e a coerência sistêmicas ${ }^{142}$ :

Os membros do Supremo Tribunal Federal, em meados de 2004, tiveram a oportunidade de se manifestar acerca desse mote. Nessa oportunidade, a Segunda Turma desse Tribunal Superior firmou o entendimento de que somente as normas jurídicas que consagram direito ou garantias individuais podem ser erigidas à categoria de cláusula pétrea, de modo que as regras imunizantes que não se enquadrarem nessa situação poderão ser alteradas por intermédio de Emenda Constitucional:

IMUNIDADE. ART. 153, § 2 $2^{\circ}$ II DA CF/88. REVOGAÇÃO PELA EC No 20/98. POSSIBILIDADE. 1. Mostra-se impertinente a alegação de que a norma art. $153, \S 2^{\circ}$, II, da Constituição Federal não poderia ter sido revogada pela $\mathrm{EC} \mathrm{n}^{\circ} 20 / 98$ por se tratar de cláusula pétrea. 2. Esta norma não

\footnotetext{
${ }^{141}$ TORRES. Ob. cit., p. 164-165.

142 São suas as seguintes palavras: "Outra fundamentação que se poderá encontrar para as imunidades será a busca, por parte do constituinte, de algum valor que lhe seja tão caro, a ponto de justificar um tratamento desigual.

Normalmente, tais valores estarão relacionados a liberdades e garantias fundamentais, assegurados constitucionalmente como base do ordenamento. Tais liberdades e garantias, por serem o alicerce do ordenamento jurídico brasileiro, não podem ser modificados sequer por emenda constitucional, como se extrai do art. $60, \S 4^{\circ}, \mathrm{IV}$, da Constituição Federal.

[...]

Finalmente, encontrar-se-ão no texto constitucional imunidades cuja função é meramente de ordem sistemática: tendo em vista a repartição de competências tributárias, houve por bem o constituinte valer-se do instituto da imunidade com a finalidade de oferecer coerência ao próprio sistema.

Tal é o caso das imunidades à exportação: tendo em vista a decisão do constituinte no sentido de desonerar as exportações e tributar as importações, adotando o que internacionalmente se consagrou como 'princípio do destino', importava assegurar que todas as pessoas jurídicas de direito público, no exercício de suas competências, se mantivessem firmes no mesmo critério." (SCHOUERI, Luís Eduardo. Direito Tributário. São Paulo: Saraiva, 2012. p. 377)
} 
consagrava direito ou garantia fundamental, apenas previa a imunidade do imposto sobre a renda a um determinado grupo social. Sua supressão do texto constitucional, portanto, não representou a cassação ou o tolhimento de um direito fundamental e, tampouco, um rompimento da ordem constitucional vigente. 3 . Recurso extraordinário conhecido e improvido. ${ }^{143}$

Corroboramos com os posicionamentos de Heleno Taveira Torres, de Luís Eduardo Schoueri e do Supremo Tribunal Federal, espelhado no acórdão cuja ementa foi transcrita acima.

Tal qual já referido, o artigo 150, inciso VI, alíneas "a", "b", “c", “d” e "e", da Constituição Federal de 1988, externa o intuito e a preocupação do Constituinte originário em resguardar não só o federalismo como, igualmente, os direitos fundamentais dos cidadãos. Dessa maneira, mesmo que se pretenda, por intermédio de Emenda Constitucional, alterar os dispositivos inseridos no artigo 150, inciso VI, alíneas de "a" a "e" da Carta Magna de 1988, tal tentativa esbarrará na dicção do artigo $60, \S 4^{\circ}$, inciso IV, o qual erigiu os direitos e garantias individuais à categoria de cláusula pétrea. Desse modo, somente uma nova Constituição Federal poderá excluir as hipóteses de imunidade tributária.

\subsection{Relação entre imunidade tributária e livre concorrência}

Uma das questões mais emblemáticas que atualmente envolvem a figura das imunidades tributárias diz respeito a sua relação com a livre concorrência.

Até que ponto a exoneração fiscal via imunidade tributária não infringe o princípio da livre concorrência? Existe limite ou o direito de não sujeição à tributação de determinadas taxas é inabalável e intransponível? Será justamente nessa intricada relação que nos embrenharemos nas próximas linhas deste trabalho científico.

A livre concorrência ${ }^{144}$ é um dos pilares do sistema capitalista ${ }^{145}$ e está disposta no artigo $173, \S 4^{\circ}$, da Carta Magna de $1988^{146}$, de modo que, como alicerce fundamental da

\footnotetext{
${ }^{143}$ RE 372.600, STF, Segunda Turma, Rel(a). Min(a). Ellen Gracie, DJ de 23.04.2004, p. 40. Disponível em: <www.stj.jus.br>. Acesso em: 29 ago. 2014.

144 Entende-se por livre concorrência a possibilidade de os agentes econômicos atuarem sem embaraços juridicamente plausíveis, em um dado mercado, visando à produção, à circulação e ao consumo de bens e serviços, de modo que todos tenham a oportunidade de competir no mercado de forma justa e igualitária.

${ }^{145}$ De acordo com Ivo Dantas, "a simples enunciação do inciso IV do art. 170 da Constituição Federal dá-nos uma das características do Estado Liberal. Contudo, esta não é a intenção do ordenamento como um todo, à luz de uma análise sistêmica, pelo que se observa do art. $173 \S 4^{\circ}$, que prescreve: 'a lei reprimirá o abuso do poder econômico que vise à dominação dos mercados, à eliminação da concorrência e ao aumento arbitrário dos lucros.' Da análise dos dois permissivos legais percebe-se, mais uma vez, a opção do constituinte por uma
} 
economia liberal e do Estado Democrático de Direito, tem por finalidade assegurar o regime de economia de mercado, não tolerando o monopólio ou quaisquer outras formas de distorção do mercado livre.

Por seu turno, a livre iniciativa é a projeção da liberdade individual no plano da produção, circulação e distribuição de riquezas, por meio da qual é viabilizada a livre escolha das atividades econômicas a serem exercidas, assim como a independente eleição dos meios julgados mais adequados à consecução dos objetivos trilhados pelo agente econômico.

A livre iniciativa está intimamente ligada ao princípio da livre concorrência, já que esta pressupõe a existência de vários agentes atuando no mercado, oferecendo o mesmo produto ou serviço em igualdade de condições, de forma que não seja possível que um desses agentes, ou parte deles, influia de modo permanente na fixação do preço dos produtos e serviços.

Não obstante a ligação entre a livre iniciativa e o princípio da livre concorrência, este difere daquela na medida em que esse princípio constitui uma baliza para a ordem econômica. A livre concorrência também leva à ideia de liberdade. Contudo, tal liberdade encontra limites nos demais princípios que regem a ordem econômica como, por exemplo, a soberania nacional, a propriedade privada e a defesa do consumidor e do meio ambiente.

É por esse motivo que Luís Eduardo Schoueri argumenta que "a livre concorrência pressupõe a livre iniciativa, mas com ela não se confunde, já que, enquanto a primeira inexiste sem a segunda, a recíproca não é verdadeira" ${ }^{, 147}$

A respeito da importância da livre concorrência no mercado, José Cretella Júnior assim se manifestou:

No regime de livre concorrência, ou de livre competição, o mercado competitivo, ou concorrencial, caracteriza-se pelo grande número de vendedores, agindo de modo autônomo, oferecendo produtos, em mercado bem organizado. No mercado competitivo, os produtos oferecidos por uma dada empresa são recebidos pelo comprador como se fossem substitutos perfeitos ou equivalentes dos produtos da firma concorrente. Na hipótese de

política econômica típica do Estado Social." (DANTAS, Ivo. Curso de direito constitucional econômico. Curitiba: Juruá, 2004. p. 73.).

146 “Art. 173. Ressalvados os casos previstos nesta Constituição, a exploração direta de atividade econômica pelo Estado só será permitida quando necessária aos imperativos da segurança nacional ou a relevante interesse coletivo, conforme definidos em lei.

[...]

$\S 4^{\circ}$ - A lei reprimirá o abuso do poder econômico que vise à dominação dos mercados, à eliminação da concorrência e ao aumento arbitrário dos lucros."

147 SCHOUERI, Luís Eduardo. Livre Concorrência e tributação.In: Grandes questões atuais do direito tributário. Valdir de Oliveira Rocha (coord.). Vol. 11. São Paulo: Dialética, 2007. p. 244. 
preços iguais, ao comprador é indiferente, regra geral, a procedência do produto, só influindo a marca, na medida em que a propaganda se intensifica. De qualquer modo, no regime da livre concorrência, os preços de mercado tendem a abaixar, beneficiando-se com isso o comprador, ao contrário do que acontece no regime de monopólio, que prejudica o comprador e afeta o equilíbrio da Ordem Econômica, a não se quando a intervenção monopolística é assegurada por lei federal, fundada em expresso dispositivo constitucional ${ }^{148}$.

Como se pode inferir pela leitura do trecho acima transcrito, ao passo que a livre concorrência intenta garantir o pleno funcionamento da economia de mercado, também proporciona aos consumidores, em razão da competitividade entre as empresas, uma posição de maior benefício. Em outras palavras: a defesa da concorrência contém em si a pretensão de evitar uma posição de superioridade em prejuízo da igualdade entre as empresas, que é primordial para o adequado desenvolvimento do mercado e do país ao mesmo tempo em que tutela as relações de consumo.

Não obstante a necessidade de observância do princípio da livre concorrência nas relações entre as pessoas, é fundamental mencionar que tal primado deve ser ponderado quando em um dos polos da relação jurídica estiver uma entidade a que o artigo 150, inciso VI, alíneas “a”, "b” e "c" da Constituição Federal faz alusão.

A saber, pela interpretação mais coerente e atualmente aceita do disposto nos $\S \S 3^{\circ} \mathrm{e}$ $4^{\text {o }}$ do artigo 150 da Constituição Federal ${ }^{149}$, todas as receitas auferidas pelas entidades imunes destinadas aos seus objetivos sociais não poderão sofrer a incidência dos impostos discriminados no texto constitucional.

Isso quer dizer, então, que basta à entidade imune empregar as receitas auferidas diretamente na consecução do seu objetivo social para que seja afastada a infração ao princípio da livre concorrência? Esse mesmo entendimento se aplica às receitas advindas da prestação de serviços ou venda de produtos não ligados diretamente ao seu objeto social ou as

${ }^{148}$ CRETELLA JÚNIOR, José. Elementos de direito constitucional. 4. ed. São Paulo: Revista dos Tribunais, 2000. p. 263.

${ }^{149}$ A título exemplificativo, citamos a recente decisão proferida pelo Pleno do Supremo Tribunal Federal, o qual, ao apreciar o Recurso Extraordinário ${ }^{\circ}$ 601.392, erigido à condição de repercussão geral, reforçou o seu entendimento segundo o qual os subsídios cruzados não ensejam a descaracterização da imunidade tributária, a menos que as rendas advindas da realização das atividades não diretamente relacionadas ao objeto social da entidade não sejam revertidas ao seu desiderato social: "1. Recurso extraordinário com repercussão geral. 2. Imunidade recíproca. Empresa Brasileira de Correios e Telégrafos. 3. Distinção, para fins de tratamento normativo, entre empresas públicas prestadoras de serviço público e empresas públicas exploradoras de atividade. Precedentes. 4. Exercício simultâneo de atividades em regime de exclusividade e em concorrência com a iniciativa privada. Irrelevância. Existência de peculiaridades no serviço postal. Incidência da imunidade prevista no art. 150, VI, 'a', da Constituição Federal. 5. Recurso extraordinário conhecido e provido." (RE 601.392, STF, Plenário, Rel. Min. Joaquim Barbosa, DJ-e de 28.02.2013). pesquisa realizada em 26.08.2014. 
rendas auferidas de forma indireta não possuem o condão de afastar a incidência do primado da livre concorrência?

Inúmeros doutrinadores já tiveram a oportunidade de externar seu posicionamento sobre a relação entre a imunidade tributária e o primado da livre concorrência insculpido no artigo $173, \S 4^{\circ}$, ambos mencionados pela Constituição Federal.

Ricardo Lobos Torres, ao analisar a relação entre imunidade tributária e princípio da livre concorrência, alegou que "rendas relacionadas às finalidades essenciais ( $\operatorname{art.} 150, \S 4^{\circ}$, da CF) tem interpretação ampla, abrangendo os lucros ou ganhos de capital e os aluguéis de imóveis, desde que destinados às finalidades essenciais da pessoa imune. Só estariam excluídos os rendimentos de atividades que possam implicar agressão ao princípio da livre concorrência" ${ }^{150}$.

Ives Gandra da Silva Martins, ao elaborar texto inserido na obra "Imunidades Tributárias", externou seu entendimento no sentido de que, pela interpretação conjunta do artigo 150, $\S 4^{\circ}$, com o artigo 173, $\S 4^{\circ}$, ambos da Constituição Federal, subentende-se que, na hipótese de as atividades, mesmo que indiretamente relacionadas às (atividades) essenciais das entidades imunes, serem idênticas ou similares às de outras empresas privadas, elas não serão imunes. Portanto, de acordo com o posicionamento desse doutrinador, independentemente de a receita estar direta ou indiretamente vinculada ao objetivo da entidade imune, se infringir o princípio da livre iniciativa, descaracterizada estará a hipótese imunitória:

Ora, o Texto Constitucional atual objetivou, na minha opinião, eliminar, definitivamente, tal possibilidade, sendo que a junção do princípio estatuído nos arts. $173, \S 4^{\circ}$, e $150, \S 4^{\circ}$, impõe a exegese de que as atividades, mesmo que relacionadas indiretamente com aquelas essenciais das entidades imunes enunciadas nos incs. b e c do artigo 150, VI, se forem idênticas ou análogas às de outras empresas privadas, não gozariam da proteção imunitória. (MARTINS, 1998, p. 45-46). ${ }^{151}$

Nos termos dos ensinamentos acima expostos, sempre que determinada atividade econômica, direta ou indireta, for explorada não com o animus de auxiliar o Estado no seu mister, mas sim o de empreender em atividades não exploradas ou subexploradas pela

\footnotetext{
${ }^{150}$ TORRES, Ricardo Lobo. Imunidades Tributárias. In: Ives Gandra da Silva Martins (coord.). Imunidades Tributárias. São Paulo: Revista dos Tribunais, 1998. p. 219.

${ }^{151}$ MARTINS, Ives Gandra da Silva. Imunidades Tributárias. In: (coord.). Imunidades Tributárias. São Paulo: Revista dos Tribunais, 1998. p. 45-46.
} 
“concorrência”, não deverá prevalecer a regra imunitória, porquanto a entidade imune estará a praticar concorrência desleal, o que é vedado pelo ordenamento jurídico pátrio.

Concordamos em parte com esse posicionamento, pois sob nossa ótica, em um primeiro momento, o fato de as receitas serem obtidas de forma direta ou indireta em relação às atividades hodiernas executadas pelas entidades imunes não possui o condão de, exclusivamente, afastar a regra imunitória sob o argumento de infração ao princípio da livre concorrência.

Nesse ponto, estamos de acordo com Diego Bonfim quando esse autor expõe que, em um primeiro momento, a utilização em seus objetivos sociais de recursos advindos da prática de atividade econômica por si só não afasta a regra imunitória por força da infração ao princípio da livre concorrência:

Com isso, já se percebe que não há como, a priori, se vedar o reconhecimento da imunidade, mesmo que se esteja diante do exercício de atividade econômica pelas entidades imunes. Havendo transferência integral dos recursos auferidos no desenvolvimento das atividades econômicas, haverá, pelo menos numa primeira análise, direito à imunidade.

É que a simples diferença de carga tributária entre concorrentes não autoriza a inferência de que haverá, no caso, distúrbio concorrencial. Mesmo que haja concorrência entre entes imunes e comerciantes não abrangidos pelas normas exonerativas, o que ofende o ordenamento jurídico é a existência de ofensa à ordem econômica, ou seja, nos termos do art. 20 da Lei n. 8.884/94, limitar, falsear ou de qualquer forma prejudicar a livre concorrência ou a livre iniciativa; dominar mercado relevante de bens ou serviços, aumentar arbitrariamente os lucros; ou exercer de forma abusiva posição dominante. ${ }^{152}$

Com isso, estamos a dizer que não basta a aplicação integral de suas receitas em seu objetivo social para manter a regra imunitória e, consequentemente, afastar a infração ao primado da livre concorrência. Esse é apenas o primeiro passo a ser dado em direção à plenitude da regra de imunidade.

Por seu turno, o segundo degrau a ser galgado para afastar-se, por completo, a ofensa à ordem econômica diz respeito a não prática de qualquer atividade que desencadeie um dos efeitos contidos no artigo $173, \S 4^{\circ}$, da Constituição Federal, os quais foram reproduzidos pelo artigo 20 da Lei ${ }^{\circ}$ 8.884, de 11 de junho de 1994 e, mais recentemente, pelo artigo 36 da Lei $\mathrm{n}^{\mathrm{o}} 12.529$, de 30 de novembro de 2011.

${ }^{152}$ BOMFIM, Diego. Tributação \& livre concorrência. São Paulo: Saraiva, 2011. p. 235. 
De acordo com esse dispositivo legal, sempre que determinada pessoa jurídica de direito privado "I - limitar, falsear ou de qualquer forma prejudicar a livre concorrência ou a livre iniciativa"; "II - dominar mercado relevante de bens ou serviços"; "III - aumentar arbitrariamente os lucros"; ou "IV - exercer de forma abusiva posição dominante", estar-se-á diante de uma infração à ordem econômica.

Dessa forma, se a entidade imune, mesmo que destine todos os recursos auferidos na consecução de seus objetivos sociais, com tal prática, "limitar, falsear ou de qualquer forma prejudicar a livre concorrência ou a livre iniciativa", "dominar mercado relevante de bens ou serviços", "aumentar arbitrariamente os lucros" 153 ou "exercer de forma abusiva posição dominante", afastará a regra imunitória.

Assim, por exemplo, se entidade beneficente de assistência social começar a produzir pães e utilizar as receitas auferidas com a venda desse produto em seu desiderato social, mantida estará a regra imunitória. Contudo, se com a venda desses singelos pãezinhos essa entidade começar a dominar o mercado de pães da região, caracterizada estará a infração à livre concorrência e a consequente não aplicação da regra de imunidade.

Importa mencionar que não basta à autoridade administrativa competente simplesmente alegar ofensa ao princípio da livre iniciativa como forma de afastar a aplicação da regra de imunidade tributária. Pelo contrário: ela deverá comprovar a efetiva ofensa a tal primado, sob pena de manutenção da condição de entidade imune da instituição sob fiscalização.

Portanto, conclui-se, pela análise das assertivas dispostas acima, que a entidade imune continuará a gozar da desoneração fiscal mesmo na hipótese de exercer atividades direta ou indiretamente ligadas ao seu objetivo social. O importante é que o produto desse mister seja totalmente revertido à consecução de seu objeto social.

Contudo, se a autoridade competente comprovar que ocorreram os distúrbios concorrenciais a que o artigo 36 da Lei ${ }^{\circ} 12.529$, de 30 de novembro de 2011, faz referência ("limitar, falsear ou de qualquer forma prejudicar a livre concorrência ou a livre iniciativa"; "dominar mercado relevante de bens ou serviços"; "aumentar arbitrariamente os lucros"; ou “exercer de forma abusiva posição dominante”), cumprir-lhe-á exigir o tributo incidente sobre as operações ditas como não alcançadas pela regra imunitória.

\footnotetext{
${ }^{153}$ Em decorrência de as entidades beneficentes de assistência social não visarem ao lucro, mas tão somente possuírem superávit, o termo "aumentar arbitrariamente os lucros" deve ser entendido como "aumentar arbitrariamente o superávit".
} 


\subsection{Interpretação das Normas de Imunidade Tributária}

Tanto o direito positivo quanto a Ciência do Direito manifestam-se pela linguagem. Dessa forma, a fim de que as normas jurídicas sejam construídas, necessário se faz, nas palavras de Paulo Ayres Barreto, desvelar o conteúdo, sentido e alcance dos textos normativos dispostos no direito positivo ${ }^{154}$.

Para que as normas jurídicas sejam construídas, o exegeta deve transitar pelos planos que compõem o sistema de direito positivo: a) S1 - plano textual (planos dos enunciados prescritivos); b) S2 - plano das significações (proposições jurídicas); c) S3 - plano das significações estruturadas (normas jurídicas); e d) S4 - plano da contextualização das significações estruturadas (sistema jurídico).

Visando à construção das normas jurídicas, o intérprete deverá se valer, além das regras de interpretação aplicáveis às normas jurídicas em geral $^{155}$, das aplicáveis à interpretação das normas de cunho constitucional, já que essas possuem características específicas que influem na sua interpretação. São elas: a) superioridade em relação às demais normas jurídicas (fundamento de validade para as demais normas jurídicas infraconstitucionais); b) linguagem representada por maior generalidade e abstração; c) caráter essencialmente político $^{156}$.

O específico método de interpretação das normas de cunho constitucional corresponde ao método evolutivo, que consiste na "atribuição de novos conteúdos à norma constitucional, sem modificação do seu teor literal, em razão de mudanças históricas ou de fatos políticos e sociais que não estavam presentes nas mentes dos constituintes". ${ }^{157}$

Por conta da peculiaridade das normas constitucionais, essas não podem ser interpretadas considerando, única e exclusivamente, o método literal ou gramatical, já que

\footnotetext{
${ }^{154}$ BARRETO, Paulo Ayres. Contribuições: regime jurídico destinação e controle. 2. ed. São Paulo: Noeses, 2011.p. 8.

${ }^{155}$ A doutrina aponta os seguintes métodos de interpretação da norma jurídica, os quais foram concebidos por Savigny:

1. gramatical ou literal: consiste na interpretação conforme o texto. "Interpreta-se" somente o que está escrito, ou seja, a literalidade do texto, a sua sintaxe;

2. sistemático: por meio desse método de interpretação, o exegeta compara a norma jurídica interpretada com outras, seja de hierarquia superior, seja de inferior, assim como com o ordenamento jurídico como um todo;

3. teleológico: trata-se de processo investigativo visando à finalidade da norma ou dos fins pretendidos pelo legislador;

4. histórico: mecanismo de detecção do processo produtivo de determinada norma jurídica e das circunstâncias que levaram o legislador a editar determinado comando normativo.

${ }^{156}$ Cf. COSTA, , 2006,p. 111.

${ }^{157}$ BARROSO, Luís Roberto. Interpretação e Aplicação da Constituição. São Paulo: Saraiva, 1996. p. 137.
} 
esse método representa o primeiro passo a ser dado em busca da construção de determinada norma jurídica $^{158}$.

Em razão da existência em nosso direito positivo do princípio da unidade do ordenamento jurídico, a interpretação sistemática, juntamente com o método de interpretação teleológica, são os métodos interpretativos mais importantes, nas palavras de Regina Helena Costa:

A interpretação sistemática, no Direito contemporâneo, juntamente com o método teleológico, revela-se um dos métodos interpretativos mais importantes.

A interpretação sistemática deflui da aplicação do princípio da unidade do ordenamento jurídico, sendo sua especificação o princípio da unidade da Constituição, segundo o qual a Constituição é um todo harmônico.

Mediante a interpretação sistemática observa-se a Constituição como um corpo normativo, de modo que não se pode compreender uma de suas normas isoladamente do contexto em que se insere.

A interpretação teleológica, por seu turno, diz como o espírito e a finalidade da norma. Carlos Maximiliano, um dos maiores estudiosos de Hermenêutica do nosso Direito, afirma ser o método teleológico aquele que merece preponderância na interpretação da Constituição.

Com efeito, a interpretação da norma jurídica, como sabido, deve considerar, antes de qualquer outro aspecto, sua finalidade, seus objetivos. Trata-se do método interpretativo mais consentâneo com a eficácia social da norma, vale dizer, com a produção de efeitos in concreto, por ocasião da sua aplicação. ${ }^{159}$

Consoante mencionado ao longo do presente trabalho científico, o legislador inseriu as imunidades tributárias no texto constitucional como forma de preservar determinados e específicos valores considerados como de superior interesse nacional, tais como a manutenção das entidades federadas, o exercício das atividades religiosas, a democracia, a educação, a saúde, a assistência aos desabrigados, o acesso à informação e à cultura. Assim, as imunidades tributárias foram incluídas no bojo da Constituição Federal com a finalidade de salvaguardar inúmeros valores extremamente caros para um Estado Democrático de Direito e para a sociedade, com o intuito de dar efetividade aos princípios contidos em tal texto normativo.

Esse, inclusive, é o entendimento uníssono da doutrina brasileira. Por todos, veja-se o entendimento de Aires Fernandino. Barreto e Paulo Ayres Barreto:

\footnotetext{
${ }^{158}$ Aliás, o método literal corresponde à etapa inicial do processo interpretativo de qualquer norma jurídica, não somente das constitucionais. Nesse sentido, Paulo de Barros Carvalho assevera que "o texto escrito, na singela conjugação de seus símbolos, não pode ser mais do que a porta de entrada para o processo de apreensão da vontade da lei; jamais confundida com a intenção do legislador" (Curso de Direito Tributário. 26. ed. São Paulo: Saraiva, 2014. p. 140.)

${ }^{159}$ COSTA, op. cit., p. 113.
} 
Desses textos normativos, podemos chegar às seguintes conclusões:

[...]

c) o exame das situações descritas pelo constituinte, no art. 150 da C.F., como imunes à tributação por via de impostos, revela que essas situações representam valores privilegiados, protegidos, consagrados pela ordem constitucional e, de conseguinte, impõe a conclusão no sentido de que essas imunidades constituem uma forma de assegurar, de garantir a eficácia jurídica dos princípios constitucionais que consagram a proteção de tais valores;

d) a interpretação sistemática da Constituição indica, assim, que o grau de amplitude dessas imunidades (as do art. 150 da C.F.) é bem mais significativo que o daquelas previstas em outros dispositivos esparsos

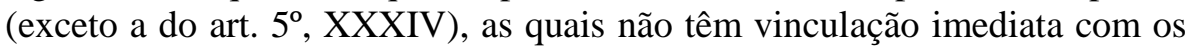
princípios constitucionais, são restritas a um só e determinado tributo e relativas a situações cujo âmbito material é específico e circunscrito.

Estas considerações mostram que o tratamento dado pelo constituinte a estas diversas imunidades é bastante diferente do que foi dispensado aos templos de qualquer culto e às entidades de educação e assistência social, no art. 150, VI. Evidentemente, as posturas são completamente diversas. Nos inúmeros casos aqui mencionados, a preocupação do constituinte foi imunizar objetivamente determinadas situações, tendo em vista peculiaridades que, topicamente, quis fazer subtraídas à tributação.

Já no que concerne às instituições de educação e de assistência social, transparece clara a preocupação subjetiva do constituinte. Em outras palavras, erigiu-se a imunidade tendo em vista um sujeito que é chamado ao mundo do direito com a precípua vocação de exercer determinadas atribuições realizadoras de valores constitucionalmente prestigiados. Essa a "ratio" da imunidade que estamos considerando. ${ }^{160}$

Em virtude de as normas constitucionais que tratam das imunidades tributárias, mormente aquelas hipóteses descritas no artigo 150, inciso VI, da Constituição Federal de 1988, visarem ao atendimento de específicos fins de relevante interesse público, o exegeta, ao interpretá-las, deverá levar em consideração tal fato.

Por conta disso, a interpretação das normas imunitórias deverá se dar com base nos métodos sistemático (analisando o sistema como um todo) e teleológico (levando em consideração a finalidade da norma criada) - o que, consequentemente, redundará em uma interpretação ampliativa.

Não obstante a necessidade de interpretação mais ampla dos preceitos imunitórios, cumpre-nos aqui fazer as ressalvas suscitadas por Regina Helena Costa ${ }^{161}$ e Marco Aurélio

\footnotetext{
${ }^{160}$ BARRETO, Aires Fernandino. e BARRETO, Paulo Ayres. Imunidades tributárias: limitações constitucionais ao poder de tributar. 2. ed. São Paulo: , 2001. p. 34-35.

${ }^{161}$ COSTA, op. cit., p. 115.
} 
Greco $^{162}$, quanto à abrangência dessa interpretação: a de que ela deve ser efetuada na medida exata, naquela necessária a fazer dela exsurgir o real valor albergado constitucionalmente.

Dessa forma, as imunidades ditas genéricas contidas no artigo 150, inciso VI, por possuírem maior abrangência (já que possuem por objeto salvaguardar inúmeros valores e aplicam-se a todos os impostos incidentes sobre as pessoas, coisas ou situações ali descritas) devem ser interpretadas de maneira mais ampla do que as imunidades tópicas espalhadas por diversos outros dispositivos contidos na Carta Magna de 1988.

Sendo assim, somos da opinião de que as imunidades tributárias contidas no artigo 150, VI, da Constituição Federal de 1988 devem ser interpretadas com base nos métodos teleológico e sistemático, de modo que seu alcance seja ampliado.

\subsubsection{Posicionamento do Supremo Tribunal Federal acerca da interpretação das} normas de imunidade tributária

O atual e dominante entendimento do Supremo Tribunal Federal acerca da interpretação das normas imunitórias, em sua grande maioria, é no sentido de que essas regras devem ser interpretadas de forma ampliativa.

Abaixo, trataremos de alguns julgados que comprovam essa assertiva.

\section{Aplicação do artigo $150, \S 2^{\circ}$ a determinadas empresas públicas e} sociedades de economia mista.

De acordo com o artigo 150, $\S 2^{\circ}$ da Constituição Federal de 1988, a imunidade recíproca é extensível às autarquias e as fundações instituídas e mantidas pelo Poder Público:

\footnotetext{
Art. 150. [...]

$\S 2^{\circ}$ - A vedação do inciso VI, "a", é extensiva às autarquias e às fundações instituídas e mantidas pelo Poder Público, no que se refere ao patrimônio, à renda e aos serviços, vinculados a suas finalidades essenciais ou às delas decorrentes.
}

Da leitura do trecho acima transcrito verifica-se que a Constituição Federal protegeu sob o manto da imunidade recíproca somente as autarquias e às fundações instituídas e mantidas pelo Poder Público.

${ }^{162}$ GRECO, Marco Aurélio. Imunidade Tributária. In: MARTINS, Ives Gandra da Silva (coord.) Imunidade Tributária. São Paulo: Dialética, 1988. p. 711. 
Não obstante esta ser a dicção extraída do texto constitucional, o Supremo Tribunal Federal firmou o entendimento de que essa hipótese de imunidade também se aplica às empresas públicas e às sociedades de economia mista, desde que ofereçam serviços públicos de prestação obrigatória e exclusiva do Estado e não tenham a intenção de lucro, enquanto se configuram como longa manus do Estado no atingimento de seus objetivos públicos.

Como exemplo desse entendimento, cita-se o acórdão proferido nos autos do Recurso Extraordinário n. 580.264, de relatoria do Ministro Joaquim Barbosa:

CONSTITUCIONAL. TRIBUTÁRIO. RECURSO EXTRAORDINÁRIO. REPERCUSSÃO GERAL. IMUNIDADE TRIBUTÁRIA RECÍPROCA. SOCIEDADE DE ECONOMIA MISTA. SERVIÇOS DE SAÚDE.

1. A saúde é direito fundamental de todos e dever do Estado (arts. $6^{\circ}$ e 196 da Constituição Federal). Dever que é cumprido por meio de ações e serviços que, em face de sua prestação pelo Estado mesmo, se definem como de natureza pública (art. 197 da Lei das leis).

2 . A prestação de ações e serviços de saúde por sociedades de economia mista corresponde à própria atuação do Estado, desde que a empresa estatal não tenha por finalidade a obtenção de lucro.

3. As sociedades de economia mista prestadoras de ações e serviços de saúde, cujo capital social seja majoritariamente estatal, gozam da imunidade tributária prevista na alínea " $a$ " do inciso VI do art. 150 da Constituição Federal.

3. Recurso extraordinário a que se dá provimento, com repercussão geral. ${ }^{163}$

Conforme se verifica pela leitura da ementa do trechotranscrita acima, o Supremo Tribunal Federal entendeu que, independentemente da denominação que se dê à empresa que funciona como longa manus do Estado, essa possui o direito de usufruir da imunidade recíproca na hipótese de prestar serviços públicos. Desse modo, o Supremo Tribunal Federal, para decidir pela aplicação ou não da imunidade, analisa a natureza do serviço prestado pela entidade: se for serviço público aplicável, será a imunidade recíproca; na hipótese de o serviço não possuir tal natureza, afastada estará a regra imunitória.

\section{Aplicação do artigo $150, \S 3^{\circ}$ a determinadas empresas públicas e} sociedades de economia mista - infração à livre concorrência

Nos termos do artigo $150, \S 3^{\circ}$, as autarquias, as fundações públicas, as empresas públicas e as sociedades de economia mista não usufruirão da imunidade recíproca na hipótese de exercerem atividades eminentemente privadas:

163 RE n. 580.264, STF, Pleno, Rel. Min. Joaquim Barbosa, DJ-e de 31.10.2008. Disponível em: <www.stf.jus.br>. Acesso em: 09 set. 2014. 
Art. 150. [...]

$\S 3^{\circ}$ - As vedações do inciso VI, "a", e do parágrafo anterior não se aplicam ao patrimônio, à renda e aos serviços, relacionados com exploração de atividades econômicas regidas pelas normas aplicáveis a empreendimentos privados, ou em que haja contraprestação ou pagamento de preços ou tarifas pelo usuário, nem exonera o promitente comprador da obrigação de pagar imposto relativamente ao bem imóvel.

O Supremo Tribunal Federal, ao apreciar a aplicação desse dispositivo constitucional às autarquias, às fundações públicas, às empresas públicas e às sociedades de economia mista, nos autos do Recurso Extraordinário n. 601.392, também erigido à condição de repercussão geral, firmou o entendimento, por maioria de votos, de que não obstante a realização de atividades atreladas ao Domínio Econômico, se o resultado do exercício dessas funções for empregado na consecução dos objetivos sociais da sociedade, presente estará a imunidade recíproca, porquanto a entidade não terá demonstrada qualquer espécie de capacidade contributiva.

Veja-se o teor da ementa desse acórdão:

Recurso Extraordinário com repercussão geral. 2. Imunidade recíproca. Empresa Brasileira de Correios e Telégrafos. 3. Distinção, para fins de tratamento normativo, entre empresas públicas prestadoras de serviço público e empresas públicas exploradoras de atividade. Precedentes. 4. Exercício simultâneo de atividades em regime de exclusividade e em concorrência com a iniciativa privada. Irrelevância. Existência de peculiaridades no serviço postal. Incidência da imunidade prevista no art. 150, VI, "a", da Constituição Federal. 5. Recurso extraordinário conhecido e provido. ${ }^{164}$

Na discussão travada nos autos desse Recurso Extraordinário, a ECT pretendia ver estendido o direito à fruição da imunidade recíproca não somente aos serviços postais propriamente ditos - serviços eminentemente de natureza pública - mas também a todos os demais serviços por ela prestados.

O Tribunal, após muita discussão e a retificação do voto por parte do Ministro Ricardo Lewandowski, assentou o entendimento de que os Correios e Telégrafos possuem direito ao gozo da imunidade recíproca, na medida em que o resultado auferido no exercício das atividades de cunho concorrencial era revertido às finalidades para as quais tal empresa

164 RE 601.392, STF, Plenário, Rel. Min. Joaquim Barbosa, DJ-e de 28.02.2013. Disponível em: <www.stf.jus.br>. Acesso em: 09 set. 2014. 
pública fora constituída. Veja-se, nesse sentido, o seguinte trecho extraído do voto do Ministro Ayres Britto:

[...] Isso tudo obriga os Correios e Telégrafos a adotar uma política tarifária de subsídios cruzados, ou seja, buscar lucro aqui para cobrir prejuízo certo ali. E como os Correios realizam também direitos fundamentais da pessoa humana, com a comunicação telegráfica e telefônica e o sigilo dessas comunicações, praticando uma política de modicidade tarifária, eles alcançam a maior parte da população carente, da população economicamente débil.

Assim, nesta oportunidade, com um pouco mais de clareza ou menos dubiedade, parece-me que os Correios são como uma longa manus, uma mão alongada das atividades da União, um apêndice da União absolutamente necessário.

Estender aos Correios o regime de imunidade tributária de que fala a Constituição está me parecendo uma coisa natural, necessária, que não pode deixar de ser, independentemente se a atividade é exclusiva ou não. No caso, parece-me que os fins a que se destinam essas atividades são mais importantes do que a própria compostura jurídica ou a estrutura jurídicoformal da empresa. $\mathrm{O}$ conteúdo de suas atividades é que me parece relevar sobremodo, à luz da Constituição.

Dessa forma, o entendimento sufragado nos autos do Recurso Extraordinário acima mencionado leva à conclusão de que os serviços prestados por empresa pública, desde que utilizados para prestar o serviço público para o qual foi criada, estão abrangidos pela imunidade recíproca. Portanto, constata-se que, também em relação a este mote, o Supremo Tribunal Federal adota uma interpretação ampliativa das hipóteses dessa espécie de imunidade contida no texto da Carta da República de 1988.

\section{Interpretação dada pelo STF em relação à imunidade dos partidos} políticos e suas fundações, sindicatos de trabalhadores, instituições de educação e de assistência social

No que diz respeito à imunidade do artigo 150, inciso VI, alínea "c", da Constituição Federal, ela abrange os partidos políticos e suas fundações, os sindicatos de trabalhadores, as instituições de educação e as instituições de assistência social.

Nos termos do $\S 4^{\circ}$ desse artigo 150, a imunidade tributária será aplicável às rendas, ao patrimônio e aos serviços prestados por tais entidades, desde que relacionados às finalidades essenciais de tais entidades: 
Art. 150. [...]

$\S 4^{\circ}$ - As vedações expressas no inciso VI, alíneas 'b" e 'c', compreendem somente o patrimônio, a renda e os serviços, relacionados com as finalidades essenciais das entidades nelas mencionadas.

Apesar de a própria Constituição Federal mencionar que serão imunes somente os impostos incidentes sobre a renda, patrimônio ou serviços das entidades a que o artigo 150, inciso VI, alínea "c" faz referência, o Supremo Tribunal Federal possui o maciço entendimento de que essa regra, em verdade, aplica-se a todos os impostos, desde que todas as receitas obtidas pelas entidades sejam revertidas aos seus objetivos sociais.

A título exemplificativo, citamos o Recurso Extraordinário n. 767.332, de relatoria do Ministro Gilmar Mendes, julgado em 31 de outubro de 2013.Nessa oportunidade, discutiu-se o reconhecimento dessa hipótese de imunidade tributária do IPTU sobre os imóveis de propriedade das entidades de educação e de assistência social, sem fins lucrativos, que não estejam sendo utilizados na fruição dos seus objetivos sociais.

De acordo com o entendimento fazendário, em razão de tais imóveis não serem utilizados, a aplicação da regra da imunidade tributária deveria ser afastada, de modo que sobre o imóvel não utilizado recairia a incidência do IPTU, já que a entidade não estaria a utilizar tal bem na consecução de seus objetivos sociais.

O Supremo Tribunal Federal, ao apreciar tal Recurso Extraordinário, o qual foi erigido à condição de repercussão geral, à unanimidade reconheceu a aplicação da regra imunitória mesmo nos casos em que o imóvel estiver vago. Veja-se a ementa desse julgado:

1. Recurso extraordinário. Repercussão geral.

2. Imunidade tributária. Instituições de educação e de assistência social, sem fins lucrativos, atendidos os requisitos da lei.

3. IPTU. Lote vago. Não incidência.

4. A imunidade tributária, prevista no art. 150 , VI, $c$, da CF/88, aplica-se aos bens imóveis, temporariamente ociosos, de propriedade das instituições de educação e de assistência social sem fins lucrativos que atendam os requisitos legais. Precedentes. 5. Recurso não provido. Reafirmação de jurisprudência. ${ }^{165}$

Em seu voto, o Ministro Relator, Gilmar Mendes, assentou que o fato de o imóvel não estar ocupado não possui o condão de afastar a aplicação da regra imunitória, porquanto a fruição da imunidade se comprova por meio do cumprimento dos requisitos dispostos na

${ }^{165}$ RE 767.332, STF, Pleno, Rel. Min. Gilmar Mendes, DJ-e de 21.11.2013. Disponível em: <www.stf.jus.br>. Acesso em: 15 set. 2014. 
legislação e não pela mera e simples inutilização de imóvel de propriedade de entidade dita imune:

\begin{abstract}
Assim, entendo que a mesma orientação deve ser aplicada ao caso em tela, dessa vez na sistemática da repercussão geral, para reconhecer que a imunidade tributária prevista no art. 150, VI, c, da Constituição Federal aplica-se inclusive aos bens imóveis, temporariamente ociosos, de propriedade das instituições de educação e de assistência social, sem fins lucrativos, desde que atendidos os requisitos legais necessários ao enquadramento nessa categoria.
\end{abstract}

Dessa forma, no que concerne a essa questão, o Supremo Tribunal Federal, elastecendo uma vez mais a regra imunitória aplicável às entidades a que o artigo 150, inciso VI, alínea "c" da Constituição Federal faz alusão, reconheceu que a destinação dos bens de propriedade das entidades imunes é irrelevante para fins de aplicação da imunidade, bastando, tão somente, que sejam preenchidos os requisitos necessários à fruição dessa benesse.

No que diz respeito às receitas advindas de aluguel de imóveis de propriedade de entidades imunes, o Supremo Tribunal Federal entende não haver a incidência de IPTU nesses casos, desde que a receita auferida seja totalmente revertida à consecução do objeto social da entidade. Tal entendimento redundou, inclusive, na edição da Súmula n. 724, segundo a qual "ainda quando alugado a terceiros, permanece a imune ao IPTU o imóvel pertencente a qualquer das entidades referidas pelo art. 150, VI, c, da Constituição, desde que o valor dos aluguéis seja aplicado nas atividades essenciais de tais entidades".

\title{
IV. Extensão da Imunidade Tributária dos "livros, jornais, periódicos e
} o papel destinado a sua impressão", a que o artigo 150, inciso VI, "d" da Constituição

\section{Federal se refere.}

Até o momento, inexiste decisão de mérito proferida pelo Supremo Tribunal Federal em sede de repercussão geral que tenha tratado da imunidade dos "livros, jornais, periódicos e o papel destinado a sua impressão",166-167.

\footnotetext{
${ }^{166}$ O STF erigiu à condição de repercussão geral o RE no 330.817, de relatoria do Ministro Dias Toffoli, no qual se discute a extensão da imunidade dos "livros, jornais e periódicos" aos livros eletrônicos.

${ }_{167}$ O STF também elevou o RE no 596.676, de relatoria do Min. Marco Aurélio, à condição de repercussão geral. Nos autos desse processo judicial, discute-se se a imunidade do art. 150, VI, "d" da CF se aplica aos componentes eletrônicos que acompanham material didático de curso de montagem de computadores. Atualmente, o placar se encontra 5 x 0 em favor dos contribuintes. $\mathrm{O}$ julgamento se encontra suspenso por conta do pedido de vista do Ministro Dias Toffoli.
} 
O que existe, em verdade, são decisões proferidas em sede de controle difuso de constitucionalidade, que tratam da imunidade dos "livros, jornais e periódicos" e do "papel destinado a sua impressão" de forma distinta e segregada.

No que toca ao mote dos livros, jornais e periódicos impressos em papel, o Supremo Tribunal Federal possui o entendimento de que a expressão "livros, jornais e periódicos" deve ser estendida aos álbuns de figurinha ${ }^{168}$, às listas telefônicas ${ }^{169}$ e às apostilas ${ }^{170}$, já que também são expressão da liberdade de expressão intelectual, artística, científica e de comunicação, bem como difundem a cultura.

Por todos, veja-se a ementa de decisão proferida nos autos do Recurso Extraordinário n. 221.239, de relatoria da Ministra Ellen Gracie:

CONSTITUCIONAL. TRIBUTÁRIO. IMUNIDADE. ART. 150, VI, "D" DA CF/88. "ÁLBUM DE FIGURINHAS". ADMISSIBILIDADE. 1. A imunidade tributária sobre livros, jornais, periódicos e o papel destinado à sua impressão tem por escopo evitar embaraços ao exercício da liberdade de expressão intelectual, artística, científica e de comunicação, bem como facilitar o acesso da população à cultura, à informação e à educação.

2. O Constituinte, ao instituir esta benesse, não fez ressalvas quanto ao valor artístico ou didático, à relevância das informações divulgadas ou à qualidade cultural de uma publicação.

3. Não cabe ao aplicador da norma constitucional em tela afastar este benefício fiscal instituído para proteger direito tão importante ao exercício da democracia, por força de um juízo subjetivo acerca da qualidade cultural ou do valor pedagógico de uma publicação destinada ao público infantojuvenil.

4. Recurso extraordinário conhecido e provido.

De acordo com a resolução transcrita acima, em decorrência de o legislador constitucional ter pretendido garantir a liberdade de expressão intelectual, artística, científica e de comunicação, é irrelevante a natureza das informações transmitidas pelos livros, jornais ou periódicos, bastando que possuam essa natureza (ser livro, jornal ou periódico em papel) para que seja reconhecida a imunidade.

\footnotetext{
${ }^{168} \mathrm{RE} \mathrm{n}^{\mathrm{o}} 221.239,2^{\mathrm{a}}$ Turma, Rel(a). Min(a). Ellen Grecie, DJ de 06.08.2004; e Ag. Reg. no RE $\mathrm{n}^{\circ}$ 656.203, $2^{\mathrm{a}}$ Turma, Rel(a). Min(a). Carmen Lúcia, DJ-e de 24.10.2012. Disponível em: 〈www.stf.jus.br〉. Acesso em: 12 set. 2014.

${ }^{169}$ RE no $^{\circ}$ 101.441, Pleno, Rel. Min. Sydney Sanches, DJ de 19.08.1988; e Ag. Reg. no RE no $778.643,1^{\text {a }}$ Turma, Rel(a). Min(a). Rosa Weber, DJ-e de 31.07.2014. Disponível em: www.stf.jus.br. Acesso em: 12 set.2014.

${ }^{170} \mathrm{RE} \mathrm{n}^{\circ}$ 183.403, $2^{\mathrm{a}}$ Turma, Rel. Min. Marco Aurélio, DJ de 04.05.2011. Disponível em: <www.stf.jus.br>. Acesso em: 12 set.2014.
} 
No que diz respeito ao "papel destinado a sua impressão", ou seja, no que toca os insumos $^{171}$ a serem utilizados na confecção dos livros, jornais e periódicos, o Supremo Tribunal Federal possui, até então, o entendimento de que essa imunidade só se aplica aos insumos equivalentes à materialidade e à natureza de papel de celulose.

Tal entendimento redundou na edição da Súmula $n^{\circ}$ 657, aprovada em 2003, que assim dispõe:

A imunidade prevista no art. 150, VI, "d”, da Constituição Federal abrange os filmes e papéis fotográficos necessários à publicação de jornais e periódicos.

Não obstante a existência dessa Súmula, no que concerne aos insumos utilizados na confecção de livros, jornais e periódicos, a jurisprudência tem sido vacilante, uma vez que existem decisões, inclusive recentes, de que estão albergados pela imunidade não somente os papéis utilizados na confecção dos livros, jornais e periódicos, mas também maquinários, recursos e produtos utilizados indiretamente na confecção de tais veículos de transmissão de conhecimento.

Tal entendimento pode ser verificado pela leitura do acórdão proferido nos autos do Recurso Extraordinário n. 202.149:

Extraia-se da Constituição Federal, em interpretação teleológica e integrativa, a maior concretude possível. IMUNIDADE - "LIVROS, JORNAIS, PERIÓDICOS E O PAPEL DESTINADO A SUA IMPRESSÃO” - ARTIGO 150, INCISO VI, ALÍNEA “D”, DA CARTA DA REPÚBLICA - INTELIGÊNCIA. A imunidade tributária relativa a livros, jornais e periódicos é ampla, total, apanhando produto, maquinário e insumos. A referência, no preceito, a papel é exemplificativa e não exaustiva. ${ }^{172}$.

Apesar de existir essa divergência de entendimentos quanto aos insumos a serem utilizados na confecção de livros, jornais e periódicos, tendo em conta o posicionamento do Supremo Tribunal Federal quanto à extensão da figura imunitória às imunidades ditas genéricas, que têm sido interpretadas de forma ampliativa, é possível que esse Tribunal Superior mantenha a coerência e reconheça o direito ao gozo da imunidade dos livros eletrônicos e dos produtos, insumos e maquinários utilizados na fabricação de livros, jornais e

\footnotetext{
${ }^{171}$ Entende-se por insumo todo o material utilizado na confecção e elaboração de determinado e específico produto, bem como na prestação de serviços.

${ }^{172}$ RE $n^{\mathbf{o}}$ 202.149, STF, $1^{\text {a }}$ Turma, Rel. Min. Menezes Direito, DJ-e de 10.10.2011. Disponível em: <www.stf.jus.br>. Acesso em: 12 set. 2014.
} 
periódicos, independentemente de os insumos serem materializados em papel de celulose ou não.

Só nos resta aguardar e acompanhar a evolução desse tema junto ao Supremo Tribunal Federal, o qual deverá apreciar, nos próximos meses, todas essas questões relacionadas à imunidade dos "livros, jornais e periódicos e o papel destinado a sua impressão". 


\section{CAPÍTULO III - ESPÉCIES DE IMUNIDADES TRIBUTÁRIAS CONTIDAS NA CONSTITUIÇÃO FEDERAL DE 1988}

\subsection{Classificação das Imunidades Tributárias}

Inexiste um consenso entre os doutrinadores pátrios no quesito classificação das imunidades tributárias. Há quem as classifique em subjetivas, objetivas e mistas ${ }^{173}$; outros categorizam-nas somente em subjetivas ${ }^{174}$; e há, outrossim, doutrinadores que as dividem em condicionadas e incondicionadas ${ }^{175}$.

Para fins do presente trabalho, haja vista o foco fundamental ser a imunidade tributária das entidades beneficentes de assistência social, adotaremos a classificação "condicionadas" e "incondicionadas"176, não desconsiderando, contudo, os esforços envidados pelos doutrinadores pátrios no sentido de criar outras classificações desse instituto.

Isso porque, tal qual exposto por Aurora Tomazini Carvalho,

\footnotetext{
${ }^{173}$ Aliomar Baleeiro em sua obra Limitações Constitucionais ao Poder de Tributar (BALEEIRO, op. cit., p. 259) classifica as imunidades em subjetiva, na medida em que alcançam pessoas; objetiva, pois englobam coisas; e mista, haja vista possuírem por objeto pessoas e coisas. Luís Eduardo Schoeuri também as classifica em subjetivas, objetivas e mistas: subjetivas são as que alcançam pessoas, em função de sua natureza jurídica; objetivas são aquelas conferidas em função de determinados fatos, bens ou situações; e mistas, as quais são revestidas tanto do aspecto objetivo, quanto do aspecto subjetivo. (SCHOUERI, Luís Eduardo. Direito Tributário. São Paulo: Saraiva, 2011. p. 378).

${ }^{174}$ Roque Antonio Carraza, por sua vez, entende que as imunidades são sempre subjetivas, porquanto sempre beneficiam pessoas (CARRAZA, Roque Antonio. Curso de Direito Constitucional Tributário. 29. ed. São Paulo: Malheiros, 2013).

175 Já Aires Barreto e Paulo Ayres Barreto entendem que as imunidades tributárias dividem-se em condicionadas e incondicionadas (BARRETO, Aires Fernandino; BARRETO, Paulo Ayres. Imunidades tributárias: limitações constitucionais ao poder de tributar. São Paulo: Dialética, 2001, 2ª ed., p. 23).

${ }^{176}$ Em vez de adotar a classificação "condicionadas" e "incondicionadas", Regina Helena Costa utiliza as expressões "condicionáveis" e "incondicionadas". Estas seriam as imunidades de eficácia plena e aplicabilidade direta e imediata, sem que haja a necessidade de preenchimento de qualquer requisito estabelecido na legislação infraconstitucional; aquelas, por seu turno, seriam as imunidades de eficácia contida e aplicabilidade imediata, mas passível de restrição, a qual poderá ou não ser estabelecida pelo legislador competente. São suas as seguintes palavras: "Por derradeiro, propomos outra classificação: aquela que separa as imunidades em incondicionadas e condicionáveis. Essa classificação leva em conta a possibilidade de contenção da eficácia da norma constitucional que abriga a exoneração tributária. Se se trata de norma constitucional de eficácia plena e aplicabilidade direta e imediata a imunidade é incondicionada, posto independer de outro comando para produzir integralmente os seus efeitos. É o caso da imunidade mútua das pessoas políticas (art. 150, VI, 'a'). Se, diversamente, a norma constitucional acolhedora da imunidade tributária qualificar-se como de eficácia contida e aplicabilidade imediata, mas passível de restrição, estar-se-á diante de uma imunidade 'condicionável' ao vocábulo 'condicionada', comumente utilizado pela doutrina, porque, como afirmamos anteriormente, a imunidade tributária não se abriga em normas constitucionais de eficácia limitada, que demandam, necessariamente, a intervenção do legislador infraconstitucional. Assim, parece-nos incorreto falar-se em imunidade condicionada, já que, cuidando-se de uma norma de eficácia contida, o condicionamento para a fruição do benefício poderá ou não ser estatuído pelo legislador complementar" (COSTA, Regina Helena. Imunidades - tributárias teoria e análise da jurisprudência do STF. 2. ed. São Paulo: Malheiros, 2006. p. 131).
} 
[...] vale lembrar que os critérios classificatórios, responsáveis pela conotação (conceito) das classes, são determinados por atos de escolha do classificador, de modo que as classificações não existem prontas no mundo, são construídas pelos homens, de acordo com suas finalidades cognoscitivas. Por este motivo, não existem classificações certas ou erradas, mas sim úteis e não úteis. Há aquelas que se prestam a descrever certos objetos sob determinadas premissas e aquelas que não se $\operatorname{prestam}^{177}$.

Em razão de o objeto principal do presente trabalho científico ser analisar a imunidade tributária às contribuições sociais destinadas à seguridade social das entidades beneficentes de assistência social, a qual se enquadra no conceito de imunidade condicionada, tal qual será demonstrado nas próximas linhas, optou-se por adotar como critério de discriminação das inúmeras espécies de imunidades tributárias dispostas na Constituição Federal de 1988 a autoexecutoridade ou não da regra posta na Carta Política de 1988.

\subsubsection{Imunidades Incondicionadas}

Entende-se por imunidade incondicionada aquela que "independe de qualquer integração de norma infraconstitucional para viabilizá-las. Ou, dito de outra forma, a Constituição não estabelece qualquer requisito, qualquer condição para que a imunidade tenha plena eficácia.",178

Dessa maneira, para que o destinatário da regra imunizante possa usufruir da imunidade tributária dita incondicionada não há necessidade de preenchimento de qualquer espécie de pressuposto a ser estabelecido por norma de caráter infraconstitucional.

Em razão de as imunidades tributárias incondicionadas serem de eficácia plena e aplicabilidade imediata, para a fruição desse benefício basta enquadrar-se nas hipóteses descritas e contidas no texto constitucional. Uma vez atendido esse requisito, seu direito à fruição da imunidade tributária será garantido e reconhecido.

Abaixo, trataremos de forma sucinta cada uma das imunidades tributárias ditas incondicionais.

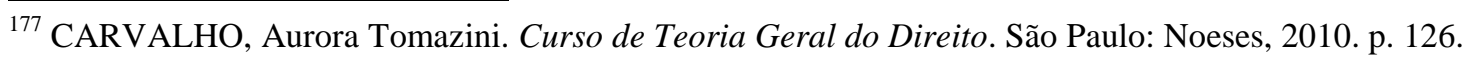

${ }^{178}$ BARRETO, Aires Fernandino; BARRETO, Paulo Ayres. Imunidades Tributárias: limitações constitucionais ao poder de tributar. 2. ed. São Paulo: Dialética, 2001. p. 14.
} 


\subsubsection{Imunidades tributárias incondicionadas do artigo 150 da $\mathbf{C F}$}

A Constituição Federal de 1988 trata em seu artigo 150, inciso VI, alíneas "a", "b”, "d" e "e" da imunidade tributária dos impostos sobre a renda, patrimônio ou serviços das pessoas e coisas ali descritas.

É importante mencionar que, não obstante a Carta Política de 1988 dispor, expressamente, que serão imunes somente os impostos sobre renda, patrimônio ou serviços da União, Estados, Distrito Federal e Municípios e dos "templos de qualquer culto", doutrina e jurisprudência são uníssonas ao estender esse obséquio a todos os impostos incidentes sobre os negócios jurídicos realizados por essas entidades e sobre os incidentes sobre o objeto da imunidade (livros, jornais, periódicos e do papel destinado a sua impressão; e fonogramas e videogramas musicais).

Abordaremos brevemente a seguir - uma vez que não é o foco de nossa pesquisa essas quatro espécies de imunidades incondicionadas dos impostos.

\section{a) Imunidade Recíproca}

A imunidade recíproca está disposta no artigo 150, inciso VI, “a”, da Constituição Federal de 1988, que assim prescreve:

Art. 150. Sem prejuízo de outras garantias asseguradas ao contribuinte, é vedado à União, aos Estados, ao Distrito Federal e aos Municípios:

$[\ldots]$

VI - instituir impostos sobre:

a) patrimônio, renda ou serviços, uns dos outros;

De acordo com esse dispositivo constitucional, os entes não podem exigir os impostos sobre renda, patrimônio e serviços um dos outros.

A imunidade recíproca constitui uma reiteração expressa do princípio da isonomia entre as pessoas políticas, corolário do preceito federativo insculpido no artigo $1^{\circ}$ da Constituição Federal de 1988. A imunidade recíproca possui ainda, como gênese, os princípios da isonomia ${ }^{179}$ e a ausência de capacidade contributiva dos entes políticos ${ }^{180}$.

\footnotetext{
${ }^{179}$ De acordo com Aires Fernandino Barreto e Paulo Ayres Barreto, "Ora, tendo a Constituição estabelecido o regime federal e, por conseguinte, fixado a isonomia entre as pessoas que compõem a Federação - segundo clássica lição de Sampaio Dória - não há falar-se em supremacia de uma pessoa sobre outra." (BARRETO, Aires F.; BARRETO, Paulo Ayres. Imunidades tributárias: limitações constitucionais ao poder de tributar. 2. ed. São Paulo: Dialética, 2001. p. 61).

${ }^{180}$ Nesse sentido, vejam-se as considerações de Luís Eduardo Schoueri: "Sob o prisma do Princípio da Capacidade Contributiva, parece certo afirmar que não se poderia admitir que uma pessoa jurídica de Direito
} 
A imunidade recíproca é a figura imunitória mais antiga dentro do sistema constitucional brasileiro. Ela foi inserida no artigo 10 da Constituição Federal de $1981^{181}$, sendo considerada por todas as demais Constituições até o presente momento.

Tal regra imunitória possui por origem o direito norte-americano. Como é sabido, a Constituição dos Estados Unidos da América, diferentemente da Carta Magna brasileira, é flexível, de modo que ela não prevê expressamente a figura da Intergovernmenal Immunity. Essa figura exonerativa passou a ter relevância para o direito norte-americano após a análise da Suprema Corte Americana do mundialmente famoso leading case McCulloch vs. Maryland.

Após a criação do Banco dos Estados Unidos da América, o Estado de Maryland pretendeu exigir o imposto sobre selagem de uma de suas filiais localizada na cidade de Baltimore, da qual o Sr. McCulloch figurava como gerente.

Por conta do julgamento deste case, a Suprema Corte Americana, na figura do relator do feito, Juiz Marshall, firmou o entendimento de que a atuação de uma pessoa jurídica de direito público, no caso o Banco da União, não poderia ser tolhida pela imposição de tributos por parte de outra pessoa jurídica de direito público, no caso o Estado de Maryland. Foi, inclusive, desse leading case que surgiu a também famosa frase proferida pelo Juiz Marshall "the power to tax envolves the power to destroy"182.

Com efeito, em razão da influência do direito norte-americano e por iniciativa de Rui Barbosa, incluiu-se, na Constituição Federal de 1891, o artigo 10 acima transcrito, o qual tratou justamente da imunidade recíproca.

Assim, por força da imunidade recíproca expressamente prevista na Constituição Federal de 1988, não só a União está protegida dos impostos estaduais e municipais, e estes dos impostos daquela, como também se garante a imunidade entre Estados e entre Municípios.

Público, atuando dentro de sua finalidade, possuísse capacidade contributiva. Tudo o que ela arrecada já é voltado aos gastos da coletividade, descabendo, pois, cogitar de parcela de 'sobra' para atender a gastos imputados a outra pessoa jurídica de Direito Público. Ou seja: a razão por que não se cobram impostos das pessoas jurídicas de Direito Público está no fato de elas não possuírem capacidade contributiva; têm, por certo, capacidade econômica, mas não há capacidade contributiva" (SCHOUERI, Luís Eduardo. Direito Tributário. 2. ed. São Paulo: Saraiva, 2012. p. 397).

181 "Art. 10 - É proibido aos Estados tributar bens e rendas federais ou serviços a cargo da União, e reciprocamente."

182 A narrativa descritiva do leading case mencionado acima foi extraída das páginas 136-137 da obra Imunidades Tributárias Teoria e Análise da Jurisprudência do STF, de Regina Helena Costa, editora Malheiros, $2^{\mathrm{a}}$ edição, 2006. 
Cumpre-nos ressaltar que a regra da imunidade recíproca aplica-se somente aos impostos, de modo que União, Estados, Distrito Federal e Municípios não encontram impedimentos constitucionais para instituir a cobrança das demais espécies de tributos descritas no texto constitucional ${ }^{183}$.

No que concerne aos impostos, ainda que a Constituição Federal mencione que somente estão abrangidos pela imunidade recíproca os impostos incidentes sobre a renda, patrimônio e serviços uns dos outros, é forçoso reconhecer que a interpretação que melhor se adéqua aos valores protegidos pela Carta Magna é a no sentido de que são imunes não somente os impostos que recaem sobre as grandezas mencionadas acima, mas sim a todos os impostos constitucionalmente previstos ${ }^{184}$.Dessa forma, por conta da imunidade recíproca, União, Estados, Distrito Federal e Municípios estão impedidos de exigir, um dos outros, todos os impostos a que a Constituição Federal faz referência e não somente sobre os que incidem sobre renda, patrimônio e serviço.

A imunidade recíproca se estende, a teor do artigo $150, \S 2^{\circ}$ da Constituição Federal, às autarquias ${ }^{185}$ e às fundações instituídas e mantidas pelo Poder Público ${ }^{186}$ no que concerne ao patrimônio, à renda e aos serviços vinculados a suas finalidades essenciais ou delas decorrentes:

\footnotetext{
${ }^{183}$ Esse também é o entendimento do Supremo Tribunal Federal, o qual já foi externado em vários de seus julgados como, por exemplo: Ag. Reg. no RE n. 388.373 (Rel. Min. Dias Toffoli, $1^{\text {a }}$ Turma, DJ-e de 23.10.2012); Ag. Reg. no RE n. 450.314 (Rel. Min. Dias Toffoli, $1^{a}$ Turma, DJ-e de 10.10.2012); Ag. Reg. no RE n. 613.287 (Rel. Min. Luiz Fux, $1^{\text {a }}$ Turma, DJ-e de 18.08.2011) - pesquisa de jurisprudência realizada em 6 set. 2014.

${ }^{184}$ Corroborando esse entendimento, veja-se a manifestação de Luís Eduardo Schoueri: "O exemplo mostra que a expressão patrimônio, renda ou serviços deve ter uma interpretação bem mais ampla: ao se referir àqueles três elementos, o constituinte procurou atingir a totalidade das situações econômicas passíveis de tributação. Recorde-se, aqui, o fluxo circular de renda, apresentado no Capítulo I, a confirmar tal assertiva. Ou seja: ainda que, juridicamente, o imposto possa incidir sobre uma transmissão de bens, ou sobre uma operação de circulação de mercadoria, economicamente todo imposto atingirá patrimônio, renda ou serviços do contribuinte. Daí parecer acertado afirmar que a imunidade recíproca estende-se a todos os impostos, qualquer que seja a hipótese tributária já que, sempre, ou o patrimônio, ou a renda, ou os serviços do ente imune serão afetados.

Nota-se, neste aspecto, que o constituinte não limitou a imunidade à propriedade, mas protegeu o patrimônio. Assim, não se vinculou a imunidade a uma relação jurídica, mas protegeram-se todo o patrimônio, todas as rendas e todos os serviços da pessoa imune" (SCHOUERI, Luís Eduardo. Direito tributário. 2. ed. São Paulo: Saraiva, 2012. p. 399).

${ }^{185}$ Nos termos do artigo $5^{\circ}$, inciso I, do Decreto-lei ${ }^{\circ}$ 600, de 25 de fevereiro de 1967, entende-se por autarquia "o serviço autônomo, criado por lei, com personalidade jurídica, patrimônio e receita próprios, para executar atividades típicas da Administração Pública, que requeiram, para seu melhor funcionamento, gestão administrativa e financeira descentralizada".

${ }_{186}$ De acordo como o artigo $5^{\circ}$, inciso IV, do Decreto-lei no 600 , de 1967, incluído pela Lei ${ }^{\circ} 7.596$, de 1987, as fundações públicas são "entidades dotadas de personalidade jurídica de direito privado, sem fins lucrativos, criada em virtude de autorização legislativa, para o desenvolvimento de atividades que não exijam execução por órgãos ou entidades de direito público, com autonomia administrativa, patrimônio próprio gerido pelos respectivos órgãos de direção, e funcionamento custeado por recursos da União e de outras fontes."
} 
Art. 150. Sem prejuízo de outras garantias asseguradas ao contribuinte, é vedado à União, aos Estados, ao Distrito Federal e aos Municípios:

VI - instituir impostos sobre: (Vide Emenda Constitucional nº 3, de 1993)

a) patrimônio, renda ou serviços, uns dos outros;

$\S 2^{\circ}$ - A vedação do inciso VI, "a", é extensiva às autarquias e às fundações instituídas e mantidas pelo Poder Público, no que se refere ao patrimônio, à renda e aos serviços, vinculados a suas finalidades essenciais ou às delas decorrentes.

A justificativa da extensão da imunidade recíproca às empresas públicas e às fundações instituídas e mantidas pelo Poder Público está atrelada ao fato de elas se sujeitarem ao regime jurídico das pessoas políticas de direito público. Logo, nada mais coerente, do ponto de vista sistêmico, do que estender esse benefício a tais entidades.

Contudo, questão mais tormentosa em relação à imunidade recíproca diz respeito à extensão desse benefício às sociedades de economia mista ${ }^{187}$ e às empresas públicas ${ }^{188}$. Apesar de esses entes não estarem expressamente protegidos pela imunidade recíproca, doutrina e jurisprudência têm o entendimento de que a eles aplica-se esse beneplácito.

Essa conclusão decorre de se ter firmado o entendimento de que as empresas públicas e as sociedades de economia mista, por serem delegatárias de serviços públicos, devem ser beneficiadas pela imunidade recíproca. Tendo em vista que essas sociedades recebem a outorga - e não faculdade - por meio de lei ${ }^{189}$, para a prestação de serviços cuja competência, inicialmente, seria da pessoa política que a criou, o regime jurídico a elas aplicado é o de direito público, não obstante tais sociedades possuírem personalidade de direito privado.

\footnotetext{
${ }^{187}$ De acordo com o artigo $5^{\circ}$, inciso III, do Decreto-lei no 600 , de 1967, com a redação dada pelo Decreto-lei ${ }^{\circ}$ 900, de 1969, sociedade de economia mista é a "entidade dotada de personalidade jurídica de direito privado, criada por lei para a exploração de atividade econômica, sob a forma de sociedade anônima, cujas ações com direito a voto pertençam em sua maioria à União ou a entidade da Administração Indireta."

${ }^{188}$ Nos termos do artigo $5^{\circ}$, inciso II, do Decreto-lei ${ }^{\circ}$ 600, de 1967, com a redação dada pelo Decreto-lei ${ }^{\circ}$ 900, de 1969, entende-se por empresa pública a "entidade dotada de personalidade jurídica de direito privado, com patrimônio próprio e capital exclusivo da União, criado por lei para a exploração de atividade econômica que o Governo seja levado a exercer por força de contingência ou de conveniência administrativa podendo revestir-se de qualquer das formas admitidas em direito."

${ }^{189}$ Nos termos do artigo 37, inciso XIX da Constituição Federal, as autarquias, empresas públicas, sociedades de economia mista e fundações, somente podem ser criadas por meio de lei a ser editada pelo ente político competente:

"Art. 37. [...]

XIX - somente por lei específica poderá ser criada autarquia e autorizada a instituição de empresa pública, de sociedade de economia mista e de fundação, cabendo à lei complementar, neste último caso, definir as áreas de sua atuação; (Redação dada pela Emenda Constitucional nº 19, de 1998)."
} 
Ora, se elas se submetem ao regime de direito público, assim como a União, os Estados, o Distrito Federal, os Municípios, as fundações públicas e as autarquias, nada mais coerente, do enfoque sistêmico, do que estender a elas a imunidade tributária recíproca ${ }^{190}$.

Este é, inclusive, o posicionamento de Regina Helena Costa ${ }^{191}$, Roque Antonio Carraza $^{192}$ e do Supremo Tribunal Federal ${ }^{193}$.

Isto posto, as empresas públicas e as sociedades de economia mista, por se submeterem ao mesmo regime da União, dos Estados, do Distrito Federal, dos Municípios,

${ }^{190}$ O mesmo entendimento não se aplica às empresas públicas e às sociedades de economia mista que exercem
atividades econômicas. Estas, por força da aplicação do artigo $173, \S 2^{\circ}$, da CF ("As empresas públicas e as
sociedades de economia mista não poderão gozar de privilégios fiscais não extensivos às do setor privado"),
sujeitam-se ao regime jurídico de direito privado, de modo que a elas não se aplica a imunidade recíproca. Nesse
sentido, vide RE no 407.099 , de Relatoria do Min. Carlos Velloso, DJ do dia 06.08 .2004 , o qual trata da distinção
de empresa pública prestadora de serviço público e empresa pública que exerce atividade econômica.
191 "O raciocínio resume-se no seguinte: se o serviço público for prestado diretamente pela pessoa política,
estará, indubitavelmente, imune à tributação por via de impostos. Ora, a mera delegação da execução desse
serviço público, pela pessoa que é titular da competência para prestá-lo à coletividade, por meio de lei, a uma
empresa por ela instituída - empresa pública ou sociedade de economia mista -, que se torna delegatária do
serviço, não pode, portanto, alterar o regime jurídico - inclusive tributário - que incide sobre a mesma prestação.
A descentralização administrativa, como expediente destinado a garantir maior eficiência na prestação de
serviços públicos (art. 37 , caput, da CF), não tem o condão de alterar o tratamento a eles dispensado,
consagrador da exoneração tributária concernente aos impostos." (Imunidades tributárias - teoria e análise da
jurisprudência do STF. 2 . ed. São Paulo: Malheiros, 2006. p. 144.).
192 "IVc - Estamos, no entanto, convencidos de que as empresas públicas e as sociedades de economia mista,
quando delegatárias de serviços públicos ou de atos de polícia, são tão imunes aos impostos quanto as próprias
pessoas políticas, a elas se aplicando, destarte, o princípio da imunidade recíproca. Enquanto prepostas à
atividade administrativa, não podem ser compelidas, nem mesmo por meio de lei, a efetuar o pagamento de
impostos. É que a Constituição, neste particular, restringe, de modo indireto, as faculdades legislativas das
pessoas políticas. Aprofundando o assunto, as empresas estatais, quando delegatárias de serviços públicos ou de atos de polícia - e que, portanto, na exploram atividades econômicas -, não se sujeitam à tributação por meio de impostos, justamente porque são a longa manus das pessoas políticas que, por meio de lei, as criam e lhes apontam os objetivos públicos a alcançar." (Curso de Direito Constitucional Tributário. 29. ed. São Paulo: Malheiros, 2013. p. 842).

193 "CASA DA MOEDA DO BRASIL (CMB) - EMPRESA GOVERNAMENTAL DELEGATÁRIA DE SERVIÇOS PÚBLICOS - EMISSÃO DE PAPEL MOEDA, CUNHAGEM DE MOEDA METÁLICA, FABRICAÇÃO DE FICHAS TELEFÔNICAS E IMPRESSÃO DE SELOS POSTAIS - REGIME CONSTITUCIONAL DE MONOPÓLIO (CF, ART. 21, VII) - OUTORGA DE DELEGAÇÃO À CMB, MEDIANTE LEI, QUE NÃO DESCARACTERIZA A ESTATALIDADE DO SERVIÇO PÚBLICO, NOTADAMENTE QUANDO CONSTITUCIONALMENTE MONOPOLIZADO PELA PESSOA POLÍTICA (A UNIÃO FEDERAL, NO CASO) QUE É DELE TITULAR - A DELEGAÇÃO DA EXECUÇÃO DE SERVIÇO PÚBLICO, MEDIANTE OUTORGA LEGAL, NÃO IMPLICA ALTERAÇÃO DO REGIME JURÍDICO DE DIREITO PÚBLICO, INCLUSIVE O DE DIREITO TRIBUTÁRIO, QU̧E INCIDE SOBRE REFERIDA ATIVIDADE - CONSEQUENTE EXTENSÃO, A ESSA EMPRESA PÚBLICA, EM MATÉRIA DE IMPOSTOS, DA PROTEÇÃO CONSTITUCIONAL FUNDADA NA GARANTIA DA IMUNIDADE TRIBUTÁRIA RECÍPROCA (CF, ART. 150, VI, "a") - O ALTO SIGNIFICADO POLÍTICO-JURÍDICO DESSA PRERROGATIVA CONSTITUCIONAL, QUE TRADUZ UMA DAS PROJEÇÕES CONCRETIZADORAS DO PRINCÍPIO DA FEDERAÇÃO - IMUNIDADE TRIBUTÁRIA DA CASA DA MOEDA DO BRASIL, EM FACE DO ISS, QUANTO ÀS ATIVIDADES EXECUTADAS NO DESEMPENHO DO ENCARGO QUE, A ELA OUTORGADO MEDIANTE DELEGAÇÃO, FOI DEFERIDO, CONSTITUCIONALMENTE, À UNIÃO FEDERAL - DOUTRINA (REGINA HELENA COSTA, "INTER ALIOS") - PRECEDENTES - RECURSO DE AGRAVO IMPROVIDO." (Ag. no RE $n^{\circ}$ 610.517, STF, $2^{\mathrm{a}}$ Turma, Rel. Min. Celso de Mello, DJ-e de 20.06.2014). Disponível em: <www.stf.jus.br〉. Acesso em: 10 set. 2014. 
das fundações públicas e das autarquias, possuem o irrestrito direito de gozar da imunidade a que o artigo 150, inciso VI, alínea "a" da Constituição Federal de 1988 faz referência.

Por fim, mas não menos importante, cumpre-nos mencionar que existe divergência entre doutrina e jurisprudência no tocante à aplicação da regra da imunidade recíproca no caso de "invasão" ao domínio econômico por parte das empresas beneficiadas por essa dádiva constitucional, mormente porque ao adentrar o "domínio econômico" o ente passaria a ter capacidade contributiva. Logo, teria condições de arcar com os impostos incidentes sobre as operações por eles realizadas.

Doutrinadores há que entendem que a partir do momento em que o Estado diretamente ou por meio das pessoas jurídicas por ele criadas - autarquias, fundações públicas, empresas públicas ou sociedades de economia mista - penetrar no Domínio Econômico, passando a exercer atividades típicas de empresas privadas, cessaria o direito à fruição da imunidade recíproca.

O fundamento constitucional para isso residiria no artigo $150, \S 3^{\circ}$ da Constituição Federal de 1988, que assim estabelece:

\begin{abstract}
Art. 150. [...]
$\S 3^{\circ}$ - As vedações do inciso VI, "a", e do parágrafo anterior não se aplicam ao patrimônio, à renda e aos serviços, relacionados com exploração de atividades econômicas regidas pelas normas aplicáveis a empreendimentos privados, ou em que haja contraprestação ou pagamento de preços ou tarifas pelo usuário, nem exonera o promitente comprador da obrigação de pagar imposto relativamente ao bem imóvel."
\end{abstract}

Assim, para os seguidores dessa corrente doutrinária, na hipótese de a empresa pública, a autarquia, a sociedade de economia mista ou a fundação pública exercer atividade não ligada diretamente ao seu objetivo social, tais atividades, por adentrarem no Domínio Econômico, ensejariam a incidência dos respectivos impostos.

Este é o entendimento de Luís Eduardo Schoueri ${ }^{194}$, Roque Antonio Carraza ${ }^{195}$ e Regina Helena Costa ${ }^{196}$, dentre outros doutrinadores. Por todos, vejam-se as considerações de Luís Eduardo Schoeri:

\footnotetext{
${ }^{194}$ SCHOUERI, Luís Eduardo. Direito Tributário. 2. ed. São Paulo: Saraiva, 2012. p. 400-401.

${ }^{195}$ CARRAZA, Roque Antonio. Curso de Direito Constitucional Tributário. 29. ed. São Paulo: Malheiros, 2013. p. 838.

${ }^{196}$ COSTA, Regina Helena. Imunidades Tributárias Teoria e Análise da Jurisprudência do STF. 2. ed. São Paulo: Malheiros, 2006. p. 146.
} 
Deste modo, quando o Estado atua no Domínio Econômico, submete-se ele ao regime jurídico próprio das empresas privadas, inclusive sob os aspectos tributários. Afinal, sua remuneração (preços públicos) se deu em ambiente de mercado e, neste, não há permitir qualquer privilégio, sob pena de se afastar o próprio mercado. Visou o constituinte, com tal providência a assegurar a plena observância do Princípio da Livre Concorrência, que ele mesmo consagrou (art. 170, IV), além de captar capacidade contributiva em ambiente onde esta se manifesta.

Assim, conclui-se que a imunidade recíproca encontra como limite o campo de atuação próprio do Estado (o setor público); quando a pessoa jurídica de Direito Público ingressa no Domínio Econômico, cessa a imunidade ${ }^{197}$

Esse, contudo, não é o entendimento do Supremo Tribunal Federal.

Assim como já referido, recentemente esse Tribunal Superior apreciou, em sede de repercussão geral, o Recurso Extraordinário n ${ }^{\circ}$ 601.392, no qual se discutiu se a Empresa Brasileira de Correios e Telégrafos, por exercer atividades de forma simultânea em regime de exclusividade - prestação de serviço público - e em concorrência com a iniciativa privada, teria direito ou não à fruição da imunidade recíproca.

A maioria dos Ministros do Supremo Tribunal Federal entendeu que os Correios e Telégrafos possuem sim direito ao gozo da imunidade recíproca, na medida em que o resultado auferido no exercício das atividades de cunho concorrencial era revertido às finalidades para as quais tal empresa pública fora constituída.

Tal entendimento está em consonância com o posicionamento do Supremo Tribunal Federal em relação ao artigo $150, \S 4^{\circ}$ da Constituição Federal, que trata da extensão da imunidade dos templos de qualquer culto e das entidades descritas no inciso VI, alínea "c" desse mesmo dispositivo constitucional a todos os impostos, e não somente os que recaem sobre o patrimônio, renda e serviços dessas entidades ou os relacionados com suas finalidades essenciais.

Tendo em vista que concordamos com a interpretação ampliativa dada pelo Supremo Tribunal Federal no que concerne ao artigo 150, § $4^{\circ}$, da Constituição Federal, conforme será melhor detalhado no item 5.1.1 do presente trabalho científico, a fim de mantermos a coerência ínsita a todo e qualquer trabalho científico, não podemos discrepar do posicionamento do Supremo Tribunal Federal no que tange à interpretação dada ao artigo 150, $\S^{\circ}$ da Constituição Federal de 1988.

${ }^{197}$ SCHOUERI, op. cit., p. 400-401. 


\section{b) Imunidade dos templos de qualquer culto}

De acordo com o artigo 150, inciso VI, "b" da Constituição Federal de 1988, são imunes aos impostos os templos de qualquer culto:

Art. 150. Sem prejuízo de outras garantias asseguradas aos contribuintes, é vedado à União, aos Estados, ao Distrito Federal e aos Municípios:

VI - instituir impostos sobre:

$[\ldots]$

b) templos de qualquer culto.

A imunidade dos "templos de qualquer culto" representa a reafirmação explícita do princípio da liberdade de crença e da prática de cultos religiosos contido no artigo $5^{\circ}$, inciso VI da Constituição Federal ${ }^{198}$.

O Texto Maior, ao proibir a exigência de imposto sobre o templo de qualquer culto, confere maior garantia a esse direito individual, de modo a impedir que o Estado crie embaraços ao exercício desse direito, o qual se aplica a qualquer espécie de religião - do catolicismo ao xamanismo, por exemplo.

Apesar de a imunidade tributária caber ao templo, quem dela se beneficia é a instituição à qual o templo pertence ${ }^{199}$. Portanto, a imunidade não recairá somente aos impostos incidentes sobre o templo em si, mas também sobre tudo relacionado aos atos praticados pela entidade religiosa tendentes à realização de sua finalidade essencial: difundir sua fé, qualquer que seja ela, aos seus fiéis. Isso diverge do que prescreve o $\S 4^{\circ}$ do artigo 150 da Constituição ${ }^{200}$.

Nesse sentido, vejam-se as palavras de Roque Antonio Carraza:

Em nosso atual ponto de vista, o $\S 4^{\circ}$ do art. 150 da $\mathrm{CF}$, ao aludir às "finalidades essenciais", não está a cuidar - ao contrário do que uma primeira leitura revela - do modo pelo qual os recursos são carreados para a Igreja, mas, sim, do lugar para onde devem ir. Desde que comprovadamente se destinem à mantença do culto e das atividades da Igreja, implementa-se o desígnio constitucional em pauta.

\footnotetext{
198 "Art. 5'. [...]

VI - é inviolável a liberdade de consciência e de crença, sendo assegurado o livre exercício dos cultos religiosos e garantida, na forma da lei, a proteção aos locais de culto e a suas liturgias; [...]."

199 BARRETO, Aires Fernandino; BARRETO, Paulo Ayres. Imunidades tributárias: limitações constitucionais ao poder de tributar. 2. ed. São Paulo: Dialética, 2001. p. 61.

200 “Art. 150. [...]

$\S 4^{\circ}$ - As vedações expressas no inciso VI, alíneas "b" e "c", compreendem somente o patrimônio, a renda e os serviços, relacionados com as finalidades essenciais das entidades nelas mencionadas."
} 
Noutras palavras, se as rendas obtidas, ainda que de forma atípica, pela instituição religiosa tiverem aplicação consentânea com as finalidades essenciais do culto, o reconhecimento da imunidade tributária é de rigor. ${ }^{201}$

O posicionamento acima é refletido na jurisprudência pátria, que interpreta a imunidade dos templos de qualquer culto de forma expansiva, de modo a considerar imunes não somente o templo em si, mas, qualquer renda, patrimônio, serviço ou receita, desde que o produto seja revertido para os fins institucionais da entidade religiosa.

A título exemplificativo, citamos o recente acórdão prolatado pelos integrantes da Primeira Turma do Supremo Tribunal Federal, sob a relatoria do Ministro Roberto Barroso:

AGRAVO REGIMENTAL EM RECURSO EXTRAORDINÁRIO COM AGRAVO. IPTU. ENTIDADE RELIGIOSA. IMUNIDADE. IMÓVEL CONEXO AO TEMPLO. UTILIZAÇÃO DE ACORDO COM OS FINS INSTITUCIONAIS. PRETENSÃO QUE DEMANDARIA REEXAME DO ACERVO PROBATÓRIO. SÚMULA 279/STF.

$O$ Tribunal de origem assentou que a entidade agravada exerce prioritariamente atividades religiosas em suas edificações, motivo pelo qual poderia gozar da imunidade. Desse modo, infere-se que a desoneração fora reconhecida em razão da compatibilidade com os requisitos indispensáveis para tanto. Não cabe ao Supremo Tribunal Federal adotar conclusões diversas quanto ao cumprimento das condições necessárias à fruição da imunidade, visto que tal providência desborda da competência desta Corte. Aplica-se ao caso a Súmula 279/STF. Agravo regimental a que se nega provimento. $^{202}$

É importante mencionar que compartilhamos do pensamento contido no acórdão acima transcrito, o qual firmou o entendimento de que mesmo desenvolvendo atividades atípicas, a entidade religiosa gozará da imunidade dos impostos, desde que o produto auferido seja revertido aos seus objetivos sociais. Agindo dessa forma, restarão plenamente assegurados e garantidos os valores da liberdade de crença e o livre exercício do culto religioso consagrados pelo texto constitucional.

Outra questão que se apresenta corresponde à extensão da imunidade dos impostos aos templos de qualquer culto aos cemitérios. Em interessante artigo sobre o assunto, Luís Eduardo Schoueri pontifica ser plenamente possível tal aplicação.

\footnotetext{
${ }^{201}$ CARRAZA, op. cit., p. 862.

${ }^{202}$ Ag. no RE no 685.246, STF, $1^{\text {a }}$ Turma, Rel. Min. Roberto Barroso, DJ-e de 28.8.2014. Disponível em: <www.stf.jus.br.>. Acesso em: 6 set. 2014.
} 
Para esse doutrinador, em linhas gerais, o cemitério também goza da imunidade do Imposto Predial e Territorial Urbano (IPTU), na medida em que nele também se praticam cultos (homenagens de caráter religioso) aos entes queridos que não mais estão conosco ${ }^{203}$.

O Supremo Tribunal Federal já teve a oportunidade de debater essa matéria. Na oportunidade, ou seja, quando do julgamento do Recurso Extraordinário n ${ }^{\circ} 578.562^{204}$, essa Corte firmou, por unanimidade de votos, o entendimento segundo o qual os cemitérios "consubstanciam extensões de entidades de cunho religioso, de modo que estão abrangidos pela imunidade do IPTU”.

Estamos de acordo com o posicionamento de Luís Eduardo Schoueri, assim como do Supremo Tribunal Federal. Tal justifica-se tendo em vista que, conforme demonstrado em tópico específico (item 2.6), as imunidades devem ser interpretadas de modo extensivo, levando em consideração o valor que pretendem resguardar. Então, nada mais coerente, da perspectiva sistêmica, do que estender a imunidade dos impostos aplicáveis aos templos de qualquer culto aos cemitérios, porquanto nesses também são realizados cultos.

Questão diametralmente oposta corresponde à suposta imunidade dos impostos aplicável à Maçonaria. Em verdade, apesar de o local em que os maçons se reúnem receber a alcunha de "Templo", nesse espaço físico não se professa qualquer espécie de religião ${ }^{205}$. Tanto é verdade que há ritos maçônicos totalmente irreligiosos. Como exemplo, pode-se citar o Rito Moderno ${ }^{206}$, o qual prega muito mais a racionalidade do que a religiosidade, bem como a liberdade de expressão em detrimento dos dogmas criados pela Igreja Católica.

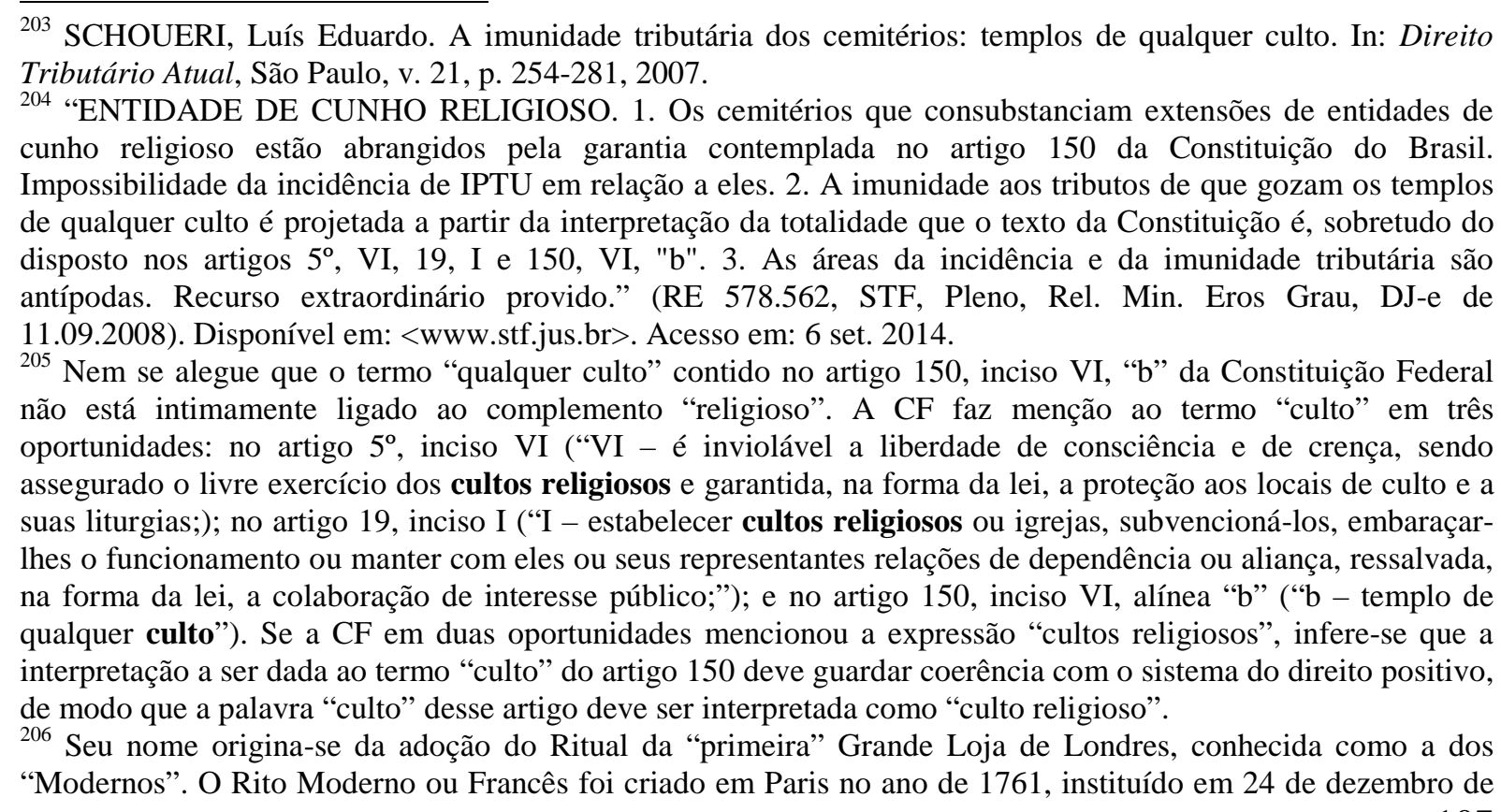


A finalidade dos encontros entre maçons é a de discutir questões ligadas à Filosofia, à Metafísica, aos problemas enfrentados pela sociedade e as formas e as ações tendentes a auxiliar as comunidades mais necessitadas, de modo que as reuniões realizadas pelos homens que integram a Ordem Maçônica em nada se assemelham à realização de cultos religiosos. Em nossa opinião, os Templos maçônicos aproximam-se mais de uma entidade de assistência social - o que ensejaria a imunidade da alínea "c" do inciso VI do artigo 150 da Constituição Federal de 1988, desde que preenchidos os requisitos dispostos no artigo 14 do Código Tributário - do que Templos nos quais são processadas reuniões de cunho religioso.

O Supremo Tribunal Federal já se manifestou acerca da aplicação ou não da imunidade dos "templos de qualquer culto" à Maçonaria. Nessa oportunidade, entendeu-se, por maioria de votos, que os Templos Maçônicos não desfrutam da imunidade a que o artigo 150, inciso VI, alínea "b" da Constituição Federal faz alusão ${ }^{207}$, já que essa ordem não professa qualquer espécie de religião, de modo que essa hipótese imunitória a ela, Maçonaria, não se aplica.

\section{c) Imunidade do livro, jornal, periódico e do papel destinado a sua impressão}

De acordo com o artigo 150, inciso VI, “d” da Constituição Federal de 1988, são imunes aos impostos o livro, os jornais, os periódicos e o papel destinado a sua impressão:

Art. 150. Sem prejuízo de outras garantias asseguradas aos contribuintes, é vedado à União, aos Estados, ao Distrito Federal e aos Municípios:

$[\ldots]$

VI - instituir impostos sobre:

$[\ldots]$

1772 e proclamado em 9 de março de 1773, pelo Grande Oriente de França, sendo instalado solenemente em 22 de outubro de 1773. No Brasil, o Rito Moderno foi fundado em 1822 pelo Grande Oriente do Brasil.

207،CONSTITUCIONAL. RECURSO EXTRAORDINÁRIO. IMUNIDADE TRIBUTÁRIA. ART. 150, VI, C, DA CARTA FEDERAL. NECESSIDADE DE REEXAME DO CONJUNTO FÁTICO-PROBATÓRIO. SÚMULA 279 DO STF. ART. 150, VI, B, DA CONSTITUIÇÃO DA REPÚBLICA. ABRANGÊNCIA DO TERMO 'TEMPLOS DE QUALQUER CULTO'. MAÇONARIA. NÃO CONFIGURAÇÃO. RECURSO EXTRAORDINÁRIO CONHECIDO EM PARTE E, NO QUE CONHECIDO, DESPROVIDO. I - O reconhecimento da imunidade tributária prevista no art. 150, VI, c, da Constituição Federal exige o cumprimento dos requisitos estabelecidos em lei. II - Assim, para se chegar-se à conclusão se o recorrente atende aos requisitos da lei para fazer jus à imunidade prevista neste dispositivo, necessário seria o reexame do conjunto fático-probatório constante dos autos. Incide, na espécie, o teor da Súmula 279 do STF. Precedentes. III - A imunidade tributária conferida pelo art. 150, VI, b, é restrita aos templos de qualquer culto religioso, não se aplicando à maçonaria, em cujas lojas não se professa qualquer religião. IV - Recurso extraordinário parcialmente conhecido, e desprovido na parte conhecida." (RE n $\mathrm{n}^{\circ}$ 562.351, STF, $1^{\text {a }}$ Turma, Rel. Min. Ricardo Lewandowski, DJ-e de 13.12.2012). Disponível em: <www.stf.jus.br〉. Acesso em: 6 set. 2014. 
d) livros, jornais, periódicos e o papel destinado a sua impressão

Trata-se, nitidamente, de espécie de imunidade objetiva, a qual recai, exclusivamente, sobre o objeto da desoneração (o livro, os jornais, os periódicos e o papel destinado a sua impressão) e não sobre quem pratica determinada operação. Por conta disso, somente estariam livres de tributação ${ }^{208}$ esses objetos de difusão da cultura e do conhecimento, o que significa dizer, consequentemente, que esse benefício não se estenderia para os detentores de tais objetos.

Fica nítido, dessa forma, que o objetivo da imunidade dos livros, jornais, periódicos e o papel destinado a sua impressão é o de garantir a liberdade de comunicação e a de pensamento e, ao mesmo tempo, facilitar a difusão da cultura e da educação do povo brasileiro. Com efeito, por conta da intenção do legislador constitucional de difundir as ideias, a cultura, o conhecimento e o entretenimento, não há que se falar em tributação dos livros ${ }^{209}$, jornais e periódicos ${ }^{210}$.

Quanto à aplicação da imunidade aos livros impressos, não há qualquer dúvida ou discussão. No entanto, os questionamentos começam a surgir a partir do momento em que esse "livro" não se apresenta mais em sua forma clássica (em papel), mas sim em formato digital. Sendo assim, cumpre-nos perguntar: a regra imunitória é aplicável aos livros ditos eletrônicos ou somente aos livros impressos em papel?

Grande parte da doutrina entende que a regra imunitória deve se aplicar aos livros ditos eletrônicos ${ }^{211}$. De acordo com os autores que professam essa tese, em virtude de o livro

\footnotetext{
${ }^{208}$ Não poderá haver a incidência do Imposto de Importação (II), do Imposto de Exportação (IE), do Imposto sobre Produtos Industrializados (IPI) e do Imposto sobre a Circulação de Mercadorias e Serviços (ICMS).

209 Livro aqui entendido como o objeto elaborado com papel, tendo como conteúdo de suas páginas encadernadas, informações, comentários, narrações, descrições, conteúdo literário, poético ou filosófico, etc.

210 Em relação à imunidade dos livros, jornais e periódicos, o Supremo Tribunal Federal já firmou o entendimento de que essa imunidade seria aplicável, inclusive, às listas telefônicas (RE $\mathrm{n}^{\circ}$ 101.441, Pleno, Rel. Min. Sydney Sanches, DJ de 19.08.1988; Ag. Reg. no RE no 778.643, $1^{\text {a }}$ Turma, Rel(a). Min(a). Rosa Weber, DJ-e de 31.07.2014), aos álbuns de figurinha (RE $n^{\circ} 221.239,2^{\mathrm{a}}$ Turma, Rel(a). Min(a). Ellen Grecie, DJ de 06.08.2004; Ag. Reg. no RE no 656.203, $2^{\text {a }}$ Turma, Rel(a). Min(a). Carmen Lúcia, DJ-e de 24.10.2012); e às apostilas (RE n ${ }^{\circ}$ 183.403, $2^{\mathrm{a}}$ Turma, Rel. Min. Marco Aurélio, DJ de 04.05.2011).

${ }^{211}$ Ricardo Lobo Torres, por exemplo, entende que a imunidade dos livros não se estende aos livros eletrônicos: "Não nos parece que a doutrina da imunidade tributária possa se extrapolar com tal facilidade para o mundo dos livros e enciclopédias 'eletrônicos', pelos argumentos anteriormente aduzidos: o 'livro eletrônico', comercializado sob a forma de CD-Rom, é um hipertexto que - lógica, operacional e finalisticamente - difere do texto do livro impresso em papel; há a possibilidade de obtê-lo diretamente na rede de informática, eis que a publicação originalmente impressa em papel pode ser transportada diretamente para a network, como acontece com outros dicionários disponíveis na Internet, que são baixados para que funcionem como hipertexto; é produto de consumo conspício, que não fica ao sabor do intervencionismo estatal.

$[\ldots]$

Resumindo, a conclusão a que chegamos é a de que a não-incidência constitucional (art. 150, VI, $d$ ) só protege os livros e jornais impressos em papel, não se projetando da 'cultura tipográfica' para a 'cultura eletrônica', nem
} 
eletrônico transmitir conhecimento, informações, dados, assim como um livro convencional (em papel), nada mais coerente, do ponto de vista do sistema de direito positivo, do que estender o beneplácito da imunidade tributária para esses suportes físicos distintos do livro em papel.

Por todos, vejam-se os ensinamentos de Aires Fernandino Barreto, Paulo Ayres Barreto e Roque Antonio Carraza:

Em resumo, a imunidade a que se refere o art. 150, VI, "d", abrange toda e qualquer espécie de livro, em suporte de qualquer natureza (impressão, CD ROM, disquete etc.), inclusive os jornais e outros programas informativos em televisão ou rádio. Nenhuma dessas modalidades de jornal, de livro ou de programa, pode ser atingida pela tributação. Nem União, nem Estados, nem Distrito Federal, nem Município podem erigi-las como hipótese de incidência de impostos.

$[\ldots]$

O correto sentido dos preceitos imunitórios só pode ser obtido mediante exegese que vá ao encontro dos valores prestigiados pela Constituição: informação, educação, cultura, desenvolvimento da pessoa, liberdade e oportunidade para aprender. ${ }^{212}$

A nosso ver, no entanto, devem ser equiparados ao livro, para fins de imunidade, os veículos de ideias, que hoje lhe fazem as vezes (livros eletrônicos) ou, até, o substituem. Tal é o caso - desde que didáticos ou científicos - dos discos, dos disquetes de computador, dos CD-Roms, dos slides, dos videocassetes, dos filmes etc.

Segundo estamos convencidos, a palavra livros está empregada no Texto Constitucional não no sentido restrito de conjunto de folhas de papel impressas, encadernadas e com capa, mas, sim, no de veículos de pensamento, isto é, de meios de difusão da cultura. Já não estamos na Idade Média, quando a cultura só podia ser difundida por intermédio de livros. Nem nos albores do Renascimento, na chamada era de Gutemberg, quando os livros eram impressos, tendo por base material o papel. Hoje temos os sucedâneos dos livros, que, mais dia menos dia, acabarão por substituí-los totalmente. Tal é o caso dos CD-Roms e dos demais artigos da espécie, que contêm, em seu interior, os textos dos livros, em sua forma tradicional. ${ }^{213}$

Por conseguinte, de acordo com o entendimento majoritário da doutrina, assim como ocorre com a imunidade recíproca dos templos de qualquer culto e das entidades políticas, sindicais, educacionais e assistenciais, o comando contido no artigo 150, inciso VI, "d" da Constituição Federal deve ser analisado de maneira ampla.

do espaço público para o espaço cibernético. Segue-se daí que não se estende ao CD-Rom, ao hipertexto para navegação nas redes de computadores e aos 'livros eletrônicos', metáfora que compreende tanto o CD-Rom como o hipertexto na network. (TORRES, Ricardo Lobo. Imunidades Tributárias. In: MARTINS, Ives Gandra da Silva (coord.). Imunidades Tributárias.. São Paulo: Revista dos Tribunais, 1998. p. 202-204).

${ }^{212}$ BARRETO, Aires Fernandino; BARRETO, Paulo Ayres. Imunidades tributárias: limitações constitucionais ao poder de tributar. 2. ed. São Paulo: Dialética, 2001. p. 90.

213 CARRAZA, Roque Antonio. Curso de Direito Constitucional Tributário. 29. ed. São Paulo: Malheiros, 2013. p. 907-908. 
Estamos totalmente de acordo com esse posicionamento. Isso porque, se a finalidade do livro impresso é transmitir o pensamento e o conhecimento, a Constituição Federal de 1988, por meio da concessão da imunidade dos livros, jornais, periódicos e o papel destinado a sua impressão tenciona prestigiar e garantir a difusão desse conhecimento. O suporte físico é o que menos importa, mormente nos tempos atuais em que impera a cultura da tecnologia e de tudo o que se inicia com a letra "i".

Ora, se o mesmo conteúdo de um livro impresso pode ser transmitido de maneira eletrônica, é essencial reconhecer que a imunidade tributária se aplica a esta "nova" forma de transmissão de informação, conhecimento. O livro em formato digital nunca deixou de ser "livro" (instrumento de transmissão de saberes, dados), só o é de maneira mais atualizada e condizente com os tempos modernos.

Nossos Tribunais já analisaram este assunto. A título exemplificativo, pode-se citar o acórdão proferido nos autos da Apelação em Mandado de Segurança n. 00052813620004036104, em trâmite perante o Tribunal Regional Federal da Terceira Região, sob a relatoria da Desembargadora Federal Consuelo Yoshida ${ }^{214}$.

214 “CONSTITUCIONAL. TRIBUTÁRIO. IMUNIDADE. LIVROS ELETRÔNICOS E ACESSÓRIOS. INTERPRETAÇÃO TELEOLÓGICA E EVOLUTIVA. POSSIBILIDADE.

1. Na hipótese dos autos, a imunidade assume a roupagem do tipo objetiva, pois atribui a benesse a determinados bens, considerados relevantes pelo legislador constituinte.

2. O preceito prestigia diversos valores, tais como a liberdade de comunicação e de manifestação do pensamento; a expressão da atividade intelectual, artística e científica e o acesso e difusão da cultura e da educação.

3. Conquanto a imunidade tributária constitua exceção à regra jurídica de tributação, não nos parece razoável atribuir-lhe interpretação exclusivamente léxica, em detrimento das demais regras de hermenêutica e do "espírito da lei' exprimido no comando constitucional.

4. Hodiernamente, o vocábulo 'livro' não se restringe à convencional coleção de folhas de papel, cortadas, dobradas e unidas em cadernos.

5. Interpretar restritivamente o art. 150, VI, 'd' da Constituição, atendo-se à mera literalidade do texto e olvidando-se da evolução do contexto social em que ela se insere, implicaria inequívoca negativa de vigência ao comando constitucional.

6. A melhor opção é a interpretação teleológica, buscando aferir a real finalidade da norma, de molde a conferirlhe a máxima efetividade, privilegiando, assim, aqueles valores implicitamente contemplados pelo constituinte.

7. Dentre as modernas técnicas de hermenêutica, também aplicáveis às normas constitucionais, destaca-se a interpretação evolutiva, segundo a qual o intérprete deve adequar a concepção da norma à realidade vivenciada.

8. Os livros são veículos de difusão de informação, cultura e educação, independentemente do suporte que ostentem ou da matéria prima utilizada na sua confecção e, como tal, fazem jus à imunidade postulada. Precedente desta E. Corte: Turma Suplementar da Segunda Seção, ED na AC n. ${ }^{\circ}$ 2001.61.00.020336-6, j. 11.10.2007, DJU 05.11.2007, p. 648.

9. A alegação de que a percepção do D. Juízo a quo ingressa no campo político não merece acolhida, haja vista que interpretar um dispositivo legal é exercício de atividade tipicamente jurisdicional.

10. Não há que se falar, de outro lado, em aplicação de analogia para ampliar as hipóteses de imunidade, mas tão-somente da adoção de regras universalmente aceitas de hermenêutica, a fim de alcançar o verdadeiro sentido da norma constitucional.

11. Apelação e remessa oficial improvidas."

(AMS n ${ }^{\circ} 00052813620004036104$, TRF da $3^{\text {a }}$ Região, $6^{\text {a }}$ Turma, Rel(a). Des(a). Fed. Consuelo Yoshida, DJ-e de 03.11.2008). 
Na oportunidade, os integrantes da Sexta Turma desse Tribunal entenderam, à unanimidade, que, tendo em vista que o legislador constitucional visou a preservar a liberdade de comunicação e de manifestação do pensamento, a melhor interpretação a ser dada ao artigo 150, inciso VI, "d" é a por meio do método teleológico, de modo que a concessão desse benefício constitucional também deve se estender aos chamados livros eletrônicos, os quais possuem por finalidade, assim como o livro em papel, a difusão da cultura e da educação.

O Supremo Tribunal Federal ainda não firmou seu entendimento no que se refere à natureza imunitória ou não dos livros eletrônicos. Atualmente, pende de análise o Recurso Extraordinário $\mathrm{n}^{\mathrm{o}} 330.817$, de relatoria do Min. Dias Toffoli, o qual foi erigido à condição de repercussão geral ${ }^{215}$.

Ainda em relação à aplicação da imunidade do "livro, jornal, periódico e o papel destinado a sua impressão", o Supremo Tribunal Federal, por meio da análise do Recurso Extraordinário n ${ }^{\circ}$ 596.676, de relatoria do Min. Marco Aurélio, também erigido à condição de repercussão geral, está apreciando se tal benesse constitucional se aplica aos componentes eletrônicos que acompanham o material didático de curso de montagem de computadores. Atualmente, o placar favorece os contribuintes, pois os Ministros Marco Aurélio, Roberto Barroso, Teori Zavaski, Rosa Weber e Luiz Fux, em sessão realizada no dia seis de agosto de 2014, votaram pelo desprovimento do Recurso Extraordinário interposto pela União Federal. O julgamento encontra-se suspenso por conta do pedido de vista do Ministro Dias Toffoli ${ }^{216}$.

Outra questão importante que orbita a imunidade dos livros, jornais e periódicos diz respeito à expressão "e ao papel destinado a sua impressão". Desse modo, a dúvida que existe e persiste é justamente saber se os insumos utilizados na elaboração dos livros, jornais e periódicos também são imunes ou se somente os papéis destinados a sua impressão, em sua forma clássica, estão abarcados pelo benefício da imunidade.

Se a Constituição Federal de 1988, em conformidade com aquilo já dito, pretendeu, por meio do artigo 150, inciso VI, "d" preservar e garantir a livre manifestação do pensamento e a difusão das ideias, independentemente do suporte físico - seja por meio do livro convencional, seja por intermédio do livro eletrônico - o mesmo entendimento deve ser aplicado em relação à expressão "e ao papel destinado a sua impressão".

Dessa forma, entendemos que a imunidade dos livros, jornais e periódicos e o papel destinado a sua impressão deve abarcar, inclusive, os demais produtos utilizados na

\footnotetext{
${ }^{215}$ Disponível em: <www.stf.jus.br>. Acesso em: 12 set.2014.

${ }^{216}$ Disponível em: www.stf.jus.br>. Acesso em: 12 set. 2014.
} 
elaboração de tais instrumentos de transmissão de conhecimento e cultura, tais como as tintas de impressão, as máquinas utilizadas para a impressão das obras, bem como os componentes utilizados na confecção dos chamados livros eletrônicos ${ }^{217}$.

A justificativa para esse entendimento reside no fato de que, se o produto acabado e a sua principal matéria-prima são imunes, não há motivo plausível para não se estender tal benefício aos insumos utilizados na confecção dos livros, principalmente se considerado que a finalidade da norma imunizante é promover a reflexão e a edificação da sapiência.

Como bem apontado por Misabel Abreu Machado Derzi, se a finalidade da imunidade dos livros é baratear a sua produção, de modo a ampliar o leque de destinatários que poderão ter acesso à informação, conhecimento, etc., a aplicação da imunidade somente ao produto acabado, "anula senão reduz, substancialmente a imunidade, eleva o custo final e quebra a neutralidade do benefício constitucional, favorecendo as empresas de impressão economicamente mais fortes" 218 .

Por mais que em matéria de imunidade genérica o posicionamento do Supremo Tribunal Federal seja no sentido de que essas normas jurídicas devem ser interpretadas de forma ampliativa, tal qual ficou consignado no tópico 2.6 acima, no que diz respeito às matérias-primas utilizadas na confecção de livros, jornais e periódicos a jurisprudência tem sido vacilante.

Ao apreciar o Agravo Regimento interposto nos autos do Recurso Extraordinário $\mathrm{n}^{\mathrm{o}}$ 504.615, a Primeira Turma do Supremo Tribunal Federal firmou o entendimento de que somente os insumos equiparáveis a papel seriam agraciados com a imunidade, na medida em que possuem relação direta com a confecção do livro ${ }^{219}$ :

AGRAVO REGIMENTAL EM RECURSO EXTRAORDINÁRIO. TRIBUTÁRIO. IMUNIDADE TRIBUTÁRIA DO ART. 150, VI, D, DA CF. ABRANGÊNCIA. IPMF. IMPOSSIBILIDADE. INTERPRETAÇÃO RESTRITIVA. AGRAVO IMPROVIDO. I - O Supremo Tribunal Federal

\footnotetext{
${ }^{217}$ Nesse sentido também aponta o entendimento de Alcides Jorge Costa, para quem "da mesma forma, pode dizer-se que livros, jornais, periódicos e o chamado papel de imprensa não são só o produto acabado, mas o conjunto de matérias-primas e materiais secundários que o compõem. Impossível restringir a imunidade ao que seria o ICMS devido apenas na operação de venda dos produtos acabados. Há, pois, que manter os créditos referentes aos insumos, para que sejam aproveitados ou transferidos a terceiros. Caso contrário, repito, frustra-se a imunidade." (COSTA, Alcides Jorge. A efetiva aplicação da imunidade de livros, jornais, periódicos e papel destinado à sua impressão. Revista Direito Tributário Atual, São Paulo, 17, p. 13-19, 20013. p. 18.

${ }^{218}$ BALEEIRO, Aliomar; DERZI, Misabel Abreu Machado. Limitações constitucionais ao poder de tributar. ed. atual. Rio de Janeiro: Forense, 2010. p. 583.

${ }_{219}$ Tal entendimento se baseia na Súmula 657, do Supremo Tribunal Federal, aprovada em 24 set. 2003, que assim dispõe: "A imunidade prevista no art. 150, VI, 'd', da Constituição Federal abrange os filmes e papéis fotográficos necessários à publicação de jornais e periódicos.”.
} 
possui entendimento no sentido de que a imunidade tributária prevista no art. 150, VI, d, da Constituição Federal deve ser interpretada restritivamente e que seu alcance, tratando-se de insumos destinados à impressão de livros, jornais e periódicos, estende-se, exclusivamente, a materiais que se mostrem assimiláveis ao papel, abrangendo, por consequência, os filmes e papéis fotográficos. Precedentes. II - A imunidade prevista no art. 150, VI, d, da Lei Maior não abrange as operações financeiras realizadas pela agravante. III - Agravo regimental improvido. ${ }^{220}$

Por outro lado, o mesmo Supremo Tribunal Federal, ao apreciar o Recurso Extraordinário $\mathrm{n}^{\circ}$ 202.149, entendeu que, haja vista os preceitos imunitórios serem interpretados com base no método teleológico, a imunidade dos "livros, jornais, periódicos e o papel destinado a sua impressão" deverá ser aplicada de modo a albergar, inclusive, os produtos, maquinários e recursos utilizados na confecção de tais obras:

Extraia-se da Constituição Federal, em interpretação teleológica e integrativa, a maior concretude possível. IMUNIDADE - "LIVROS, JORNAIS, PERIÓDICOS E O PAPEL DESTINADO A SUA IMPRESSÃO" - ARTIGO 150, INCISO VI, ALÍNEA “D”, DA CARTA DA REPÚBLICA - INTELIGÊNCIA. A imunidade tributária relativa a livros, jornais e periódicos é ampla, total, apanhando produto, maquinário e insumos. A referência, no preceito, a papel é exemplificativa e não exaustiva. ${ }^{221}$.

Nada obstante, levando em consideração o posicionamento desse Tribunal quanto à interpretação das imunidades tributárias ditas genéricas, as quais têm sido interpretadas com base no método teleológico, espera-se que esse Tribunal mantenha a coerência e reconheça o direito ao gozo da imunidade inclusive das matérias-primas e maquinários utilizados na elaboração de livros, jornais e periódicos.

\section{d) Imunidade de fonogramas e videogramas musicais e dos respectivos} suportes materiais ou arquivos digitais que os contenham

Recentemente, mais precisamente em 15 de outubro de 2013, foi promulgada a Emenda Constitucional no 75, que inseriu no artigo 150, inciso VI, alínea "e" da Constituição Federal mais uma hipótese de imunidade: trata-se da imunidade tributária objetiva, assim como ocorre em relação aos livros, jornais e periódicos, aplicável sobre os fonogramas e os

\footnotetext{
${ }^{220}$ Ag. Reg. no RE no 504.615, STF, $1^{\text {a }}$ Turma, Rel. Min. Ricardo Lewandowski, DJ-e de 03.05.2011 Disponível em: <www.stf.jus.br>. Acesso em: 12 set. 2014.

${ }^{221}$ RE n. 202.149, STF, $1^{\text {a }}$ Turma, Rel. Min. Menezes Direito, DJ-e de 10.10.2011 - pesquisa realizada junto ao sítio do Supremo Tribunal Federal (www.stf.jus.br) em 12.09.2014.
} 
videogramas musicais e aos respectivos suportes materiais ou arquivos digitais que os contenham:

\begin{abstract}
Art. 150
$[\ldots]$

$\mathrm{VI}-$

[...]e) fonogramas e videofonogramas musicais produzidos no Brasil contendo obras musicais ou literomusicais de autores brasileiros e/ou obras em geral interpretadas por artistas brasileiros bem como os suportes materiais ou arquivos digitais que os contenham, salvo na etapa de replicação industrial de mídias ópticas de leitura a laser.
\end{abstract}

Essa nova espécie de imunidade veio a complementar o rol de proteção constitucional já dada aos meios de difusão de pensamentos, ideias e, especialmente, culturas. A finalidade dessa espécie de imunidade é a de proteger a manifestação da cultura nacional em detrimento da internacional.

Afora essa finalidade cultural, a criação dessa nova espécie de imunidade também possui um viés econômico, já que se pretende fortalecer a produção musical brasileira que se dá dentro da legalidade face a cada vez mais atuante indústria da pirataria e da troca de arquivos digitais por meio da Internet.

E isso fica muito claro ao se analisar a Exposição de Motivos da Emenda Constitucional $n^{\circ} 75$. Dentre os principais argumentos para a instituição dessa modalidade de imunidade, destacamos os seguintes:

A proposta de emenda constitucional em apreço cuida de estabelecer imunidade tributária para a produção musical brasileira bem como a comercialização de seus suportes físicos e digitais tendo como única restrição para sua imunidade que estes contenham músicas compostas ou gravadas por autores ou artistas brasileiros, medida que nos parece poder vir a contribuir para reverter o atual quadro de favorecimento da indústria da pirataria, que vemos se solidificar a cada dia em detrimento dos produtos legalmente produzidos e comercializados no País.

$[\ldots]$

A presente proposta de emenda constitucional pretende interferir nesse quadro retirando de cena um fator que efetivamente torna a concorrência entre o produto pirata e o original quase impraticável: o alto preço dos impostos que recaem sobre esse último, tornando seu custo final muitíssimo maior para o consumidor. Independentemente da qualidade técnica, sabidamente muito inferior no produto ilegal, e mesmo do eventual desejo do comprador de prestigiar o trabalho genuíno do artista nacional, o apelo do baixo preço acaba se tornando irresistível, notadamente para aquela faixa da população com poucos recursos, que não pode se dar ao luxo de escolher um produto mais caro quando exista no mercado oferta de outros equivalentes por menor custo. 
$[\ldots]$

Acreditamos que a instituição de imunidade tributária para a produção e a comercialização da música composta e/ou gravada por artistas brasileiros e comercializada em seus diversos suportes, a exemplo do que já ocorre com "livros, jornais, periódicos e o papel destinado a sua impressão", pode atenuar sensivelmente a barreira econômica que pesa sobre o produto original, tornando-o mais acessível ao consumo popularizando ainda mais seu acesso às classes menos privilegiadas do País, difundindo e consolidando este importante alicerce da cultura brasileira e, por isso mesmo, dando à música a condição de retomar um merecido lugar de destaque na economia nacional.

Em razão de tratar-se de regra imunitória deveras recente, não se sabe ao certo qual será a extensão que o Supremo Tribunal Federal dará a sua interpretação. Contudo, baseandose nas decisões existentes, até o momento, no que toca aos livros, jornais e periódicos, entendemos que esse Tribunal Superior manterá a mesma linha de raciocínio e de pensamento. Só nos resta aguardar se a lógica prevalecerá ou se o Supremo aproveitará a oportunidade para rever alguns de seus conceitos e posicionamentos.

\subsubsection{Outras hipóteses de imunidades tributárias incondicionadas referentes} aos impostos

Além das hipóteses de imunidades aos impostos descritas acima, a Constituição Federal de 1988 elenca outras situações, as quais possuem campo de abrangência mais limitado, porquanto só se enquadram nessas condições uma espécie de imposto. São elas:

\section{a) Imposto sobre Produtos Industrializados (IPI):}

Nos termos do artigo $153, \S 3^{\circ}$, inciso III da Constituição Federal, são imunes ao IPI os produtos destinados ao exterior, não obstante o texto constitucional mencionar a expressão "não incidirá",222:

Art. 153. Compete à União instituir impostos sobre:

$[\ldots]$

IV - produtos industrializados;

$[\ldots]$

\footnotetext{
${ }^{222}$ Consoante mencionado alhures, a forma exonerativa de cunho constitucional recebe a denominação de imunidade, de modo que sempre que o legislador constituinte utilizar a expressão "não incidirá" o legislador infraconstitucional e o exegeta deverão interpretá-la como sendo hipótese de "imunidade". E isso se aplica não só ao artigo 153, da Carta Magna de 1988, mas, por óbvio, a todos os artigos que mencionem em seu bojo a expressão "não incidirá":
} 
$\S 3^{\circ}-\mathrm{O}$ imposto previsto no inciso IV:

[...]

III - não incidirá sobre produtos industrializados destinados ao exterior.

b) Imposto sobre a Circulação de Mercadorias e sobre a prestação de Serviços de transporte interestadual e intermunicipal e de comunicação (ICMS):

O mesmo artigo da Constituição Federal de 1988 que trata da competência dos Estados e do Distrito Federal para instituir o ICMS estabelece as situações, pessoas ou coisas sobre as quais esses entes públicos não poderão valer-se da exigência desse imposto, por expressa previsão constitucional nesse sentido.

Art. 155. Compete aos Estados e ao Distrito Federal instituir impostos sobre: (Redação dada pela Emenda Constitucional n 3, de 1993)

II - operações relativas à circulação de mercadorias e sobre prestações de serviços de transporte interestadual e intermunicipal e de comunicação, ainda que as operações e as prestações se iniciem no exterior; (Redação dada pela Emenda Constitucional $n^{\circ} 3$, de 1993)

$\S 2 .^{\circ} \mathrm{O}$ imposto previsto no inciso II atenderá ao seguinte: (Redação dada pela Emenda Constitucional nº 3, de 1993)

$\mathrm{X}$ - não incidirá:

a) sobre operações que destinem mercadorias para o exterior, nem sobre serviços prestados a destinatários no exterior, assegurada a manutenção e o aproveitamento do montante do imposto cobrado nas operações e prestações anteriores; (Redação dada pela Emenda Constitucional no 42, de 19.12.2003) b) sobre operações que destinem a outros Estados petróleo, inclusive lubrificantes, combustíveis líquidos e gasosos dele derivados, e energia elétrica;

c) sobre o ouro, nas hipóteses definidas no art. $153, \S 5^{\circ}$;

d) nas prestações de serviço de comunicação nas modalidades de radiodifusão sonora e de sons e imagens de recepção livre e gratuita; (Incluído pela Emenda Constitucional n ${ }^{\circ} 42$, de 19.12.2003)

A primeira hipótese de imunidade do ICMS corresponde à impossibilidade de exigência desse imposto sobre mercadorias remetidas ao exterior e sobre serviços cujos destinatários estejam localizados no exterior, nos termos do artigo $155, \S 2^{\circ}$, inciso X, alínea "a".

A segunda hipótese de imunidade de ICMS veda a incidência desse imposto sobre as operações por meio das quais são destinados petróleo, inclusive lubrificantes, combustíveis líquidos e gasosos dele derivados e energia elétrica a outros estados da Federação, de acordo como o artigo $155, \S 2^{\circ}$, inciso $X$, alínea “b”.É importante mencionar que essa vedação constitucional aplica-se somente aos combustíveis líquidos e gasosos derivados de petróleo. 
Outras fontes de derivação de combustível como, por exemplo, o álcool ou o gás, estão fora do campo de atuação das imunidades.

A terceira hipótese de imunidade de ICMS veda a incidência desse imposto sobre a energia elétrica destinada a outros estados da Federação, de acordo como o artigo 155, § $2^{\circ}$, inciso X, alínea "b", parte final.

A “quarta hipótese" de imunidade de ICMS está contida no artigo $155, \S 2^{\circ}$, inciso X, alínea "c", o qual veda a incidência desse imposto sobre as operações com ouro, quando definido como ativo financeiro ou instrumento cambial, nos termos do artigo $153, \S 5^{\circ}$, da Constituição Federal ${ }^{223}$.

Conforme se verifica, a Carta Magna de 1988 veda a exigência de ICMS nas operações que tenham por objeto o ouro definido em lei como ativo financeiro ou instrumento cambial (ouro-financeiro), que somente poderá ser objeto de cobrança do IOF. Por sua vez, o ouro considerado mercadoria (ouro-mercadoria) poderá, perfeitamente, ser tributado via ICMS.

Não obstante a regra contida no artigo $155, \S 2^{\circ}$, inciso X, alínea "c" ser "redundante", nas palavras de Regina Helena $\operatorname{Costa}^{224}$, haja vista o artigo 153 , § $5^{\circ}$, da Constituição Federal de 1988 estabelecer que o ouro-financeiro somente sofrerá a incidência de IOF, entendemos que, em verdade, essa hipótese desonerativa corresponde à figura da "não incidência" e não de "imunidade" propriamente dita, de modo que, sob nossa ótica, tal dispositivo constitucional é totalmente despiciendo.

A suposta "quinta hipótese" de imunidade do ICMS diz respeito à impossibilidade de os Estados e do Distrito Federal exigirem esse imposto "nas prestações de serviços de comunicação nas modalidades de radiodifusão sonora e de sons e imagens de recepção livre gratuita", nos termos do artigo $155, \S 2^{\circ}$, inciso X, alínea "d" da Constituição Federal de 1988. Ocorre que, assim como se dá em relação ao ouro-financeiro, que está fora do campo de incidência do ICMS, o mesmo acontece com as prestações de serviços de rádio e de TV gratuitos.

\footnotetext{
223 “Art. 153. Compete à União instituir impostos sobre:

$[\ldots]$

V - operações de crédito, câmbio e seguro, ou relativas a títulos ou valores mobiliários;

$[\ldots] \S 5^{\circ}-\mathrm{O}$ ouro, quando definido em lei como ativo financeiro ou instrumento cambial, sujeita-se exclusivamente à incidência do imposto de que trata o inciso $\mathrm{V}$ do 'caput' deste artigo, devido na operação de origem; a alíquota mínima será de um por cento, assegurada a transferência do montante da arrecadação nos seguintes termos:"

${ }^{224}$ COSTA, Regina Helena. Imunidades tributárias teoria e análise da jurisprudência do STF. 2. ed. São Paulo: Malheiros, 2006. p. 201.
} 
Isso porque, os Estados e o Distrito Federal apenas poderão exigir o ICMS sobre a prestação onerosa de serviços de telecomunicação, pois a Constituição Federal de 1988 somente autoriza a instituição de impostos desde que respeitado o princípio da capacidade contributiva. Assim, se a prestação do serviço de telecomunicação se der de forma gratuita, não haverá que se falar em incidência de ICMS sobre a prestação de serviços de comunicação via rádio e TV, por total ausência de capacidade contributiva ${ }^{225}$.

Dessa forma, apesar de a Constituição Federal de 1988 preconizar que existem cinco hipóteses de imunidade do ICMS, entendemos que, em verdade, o artigo 155 desse mesmo diploma legal somente estabelece três espécies de imunidades desse imposto, que seriam: imunidade desse tributo sobre as mercadorias ao exterior e sobre serviços cujos destinatários estejam localizados no exterior; imunidade desse imposto sobre as operações por meio das quais são destinados petróleo, inclusive lubrificantes, combustíveis líquidos e gasosos dele derivados a outros estados da Federação; e imunidade desse tributo sobre as operações por meio das quais se destina energia elétrica a outros estados da Federação, de modo que as outras duas hipóteses configuram-se como hipóteses de "não incidência".

\section{c) Imposto sobre a Transmissão Inter Vivos de Bens Imóveis (ITBI):}

No que diz respeito ao ITBI, que possui matriz constitucional no artigo 156, a Constituição Federal também elenca as situações, pessoas ou coisas sobre as quais os Municípios e o Distrito Federal não poderão lançar seu manto tributário sobre os contribuintes. São elas:

Art. 156. Compete aos Municípios instituir impostos sobre:

$[\ldots]$

II - transmissão "inter vivos", a qualquer título, por ato oneroso, de bens imóveis, por natureza ou acessão física, e de direitos reais sobre imóveis, exceto os de garantia, bem como cessão de direitos a sua aquisição;

$[\ldots]$

$\S 2^{\circ}$ - O imposto previsto no inciso II:

I - não incide sobre a transmissão de bens ou direitos incorporados ao patrimônio de pessoa jurídica em realização de capital, nem sobre a transmissão de bens ou direitos decorrente de fusão, incorporação, cisão ou extinção de pessoa jurídica, salvo se, nesses casos, a atividade preponderante do adquirente for a compra e venda desses bens ou direitos, locação de bens imóveis ou arrendamento mercantil;

\footnotetext{
${ }^{225}$ Em sentido idêntico, vejam-se as palavras de Roque Antonio Carraza (CARRAZA, Roque Antonio. Curso de Direito Constitucional Tributário. 29. ed. São Paulo: Malheiros, 2013. p. 951-957) e Regina Helena Costa (COSTA, Regina Helena. Imunidades tributárias - teoria e análise da jurisprudência do STF. 2. ed. São Paulo: Malheiros, 2006. p. 202.
} 
A primeira hipótese de imunidade do ITBI está no caput do artigo 156 acima transcrito. De acordo com esse dispositivo normativo, os Municípios e o Distrito Federal não poderão exigir esse imposto quando houver a transmissão a qualquer título, por ato oneroso, dos direitos reais de garantia sobre os imóveis.

As outras duas hipóteses de imunidade do ITBI estão descritas no $\S 2^{\circ}$, inciso II e dizem respeito à impossibilidade de os entes competentes exigirem esse imposto nos casos de integralização de capital social de sociedade por meio de bens imóveis e nos casos de transmissão de bens ou direitos decorrentes de fusão, incorporação, cisão ou extinção de pessoa jurídica, salvo se a atividade preponderante do adquirente for a compra e venda desses bens ou direitos, locação de bens imóveis ou arrendamento mercantil ${ }^{226}$.

\section{d) Outros impostos exonerados}

Afora as hipóteses de imunidades incondicionadas de determinados e específicos impostos, a Constituição Federal, em duas oportunidades, menciona casos de exoneração de mais de um imposto - que não os incidentes sobre a renda, patrimônio e serviços. Tratam-se da impossibilidade de tributação, via impostos federais, estaduais e municipais sobre as operações de transferência de imóveis desapropriados para fins de reforma agrária.

A primeira dessas hipóteses está disposta no artigo $155, \S 3^{\circ}$ da Constituição Federal de 1988:

Art. 155. Compete aos Estados e ao Distrito Federal instituir impostos sobre: (Redação dada pela Emenda Constitucional nº 3, de 1993)

[...]

II - operações relativas à circulação de mercadorias e sobre prestações de serviços de transporte interestadual e intermunicipal e de comunicação,

\footnotetext{
${ }^{226}$ O normativo que estabelece o que vem a ser "atividade preponderante" é o artigo 37 do Código Tributário Nacional, que assim dispõe:

“Art. 37. O disposto no artigo anterior não se aplica quando a pessoa jurídica adquirente tenha como atividade preponderante a venda ou locação de propriedade imobiliária ou a cessão de direitos relativos à sua aquisição. $\S 1^{\circ}$ Considera-se caracterizada a atividade preponderante referida neste artigo quando mais de $50 \%$ (cinqüenta por cento) da receita operacional da pessoa jurídica adquirente, nos 2 (dois) anos anteriores e nos 2 (dois) anos subsequientes à aquisição, decorrer de transações mencionadas neste artigo.

$\S 2^{\circ}$ Se a pessoa jurídica adquirente iniciar suas atividades após a aquisição, ou menos de 2 (dois) anos antes dela, apurar-se-á a preponderância referida no parágrafo anterior levando em conta os 3 (três) primeiros anos seguintes à data da aquisição.

$\S 3^{\circ}$ Verificada a preponderância referida neste artigo, tornar-se-á devido o imposto, nos termos da lei vigente à data da aquisição, sobre o valor do bem ou direito nessa data.

$\S 4^{\circ} \mathrm{O}$ disposto neste artigo não se aplica à transmissão de bens ou direitos, quando realizada em conjunto com a da totalidade do patrimônio da pessoa jurídica alienante."
} 
ainda que as operações e as prestações se iniciem no exterior; (Redação dada pela Emenda Constitucional no 3, de 1993)

$[\ldots]$

$\S 3^{\circ}$ À exceção dos impostos de que tratam o inciso II do caput deste artigo e $\mathrm{o}$ art. 153, I e II ${ }^{227}$, nenhum outro imposto poderá incidir sobre operações relativas a energia elétrica, serviços de telecomunicações, derivados de petróleo, combustíveis e minerais do País. (Redação dada pela Emenda Constitucional $n^{\circ} 33$, de 2001)

Conforme se infere pela leitura dos trechos acima transcritos, sobre as operações de energia elétrica, serviços de telecomunicações, derivados de petróleo, combustíveis e minerais, só poderá haver a incidência de ICMS, de Imposto de Importação e de Imposto de Exportação.

É importante mencionar que, por tratar-se de imunidade dita objetiva, tal regra aproveita, única e exclusivamente, às operações e não às pessoas que realizam tais negócios jurídicos, de modo que deverá haver o recolhimento dos demais não excepcionados.

A segunda dessas hipóteses está descrita no artigo 184, § 5º da Constituição Federal de 1988:

Art. 184. Compete à União desapropriar por interesse social, para fins de reforma agrária, o imóvel rural que não esteja cumprindo sua função social, mediante prévia e justa indenização em títulos da dívida agrária, com cláusula de preservação do valor real, resgatáveis no prazo de até vinte anos, a partir do segundo ano de sua emissão, e cuja utilização será definida em lei.

$[\ldots]$

$\S 5^{\circ}$ - São isentas de impostos federais, estaduais e municipais as operações de transferência de imóveis desapropriados para fins de reforma agrária.

Conforme mencionado no item 2.2, toda e qualquer exoneração fiscal disposta na Constituição Federal receberá o nome de imunidade tributária, de modo que, não obstante o legislador constitucional ter mencionado que as operações de transferência de imóveis para fins de reforma agrária são "isentas" dos impostos federais, estaduais e municipais, tal comando encerra, em verdade, imunidade e não isenção.

\footnotetext{
227 “Art. 153. Compete à União instituir impostos sobre:

I - importação de produtos estrangeiros;

II - exportação, para o exterior, de produtos nacionais ou nacionalizados;"
} 


\title{
3.1.1.3. Imunidades tributárias incondicionadas correspondentes às
}

\section{Contribuições Sociais}

A Constituição Federal de 1988 trata somente de três hipóteses de imunidade incondicionada das contribuições sociais.

A primeira delas encontra-se encampada no artigo $149, \S 2^{\circ}$, inciso I, que assim estabelece:

\begin{abstract}
Art. 149. Compete exclusivamente à União instituir contribuições sociais, de intervenção no domínio econômico e de interesse das categorias profissionais ou econômicas, como instrumento de sua atuação nas respectivas áreas, observado o disposto nos arts. 146, III, e 150, I e III, e sem prejuízo do previsto no art. $195, \S 6^{\circ}$, relativamente às contribuições a que alude o dispositivo.

$[\ldots]$

$\S 2^{\circ}$ As contribuições sociais e de intervenção no domínio econômico de que trata o caput deste artigo: (Incluído pela Emenda Constitucional $n^{\circ} 33$, de 2001)

I - não incidirão sobre as receitas decorrentes de exportação; (Incluído pela Emenda Constitucional n 33 , de 2001)".
\end{abstract}

Como se vê pela análise do artigo acima transcrito, a Constituição Federal, visando a desonerar as exportações, estabeleceu a imunidade das contribuições sociais e de intervenção no domínio econômico das receitas decorrentes de exportação.

Tão $\log$ o foi publicada a Emenda Constitucional no 33, de 11 de dezembro de 2001, começou-se a discutir qual a abrangência dessa regra imunitória, ou seja, se seria aplicada somente sobre as receitas, pura e simples, decorrentes da exportação de bens e serviços ou se tal regra seria estendida aos conceitos de faturamento e de lucro.

Apesar dos esforços envidados pelos contribuintes, o Supremo Tribunal Federal, ao apreciar os Recursos Extraordinários $\mathrm{n}^{\mathrm{os}} 474.132^{228}, 564.413^{229}$ e $627.815^{230}$ assentou o

228 "Recurso extraordinário. 2. Contribuições sociais. Contribuição Social sobre o Lucro Líquido (CSLL) e Contribuição Provisória sobre Movimentação ou Transmissão de Valores e de Créditos e Direitos de Natureza Financeira (CPMF). 3. Imunidade. Receitas decorrentes de exportação. Abrangência. 4. A imunidade prevista no art. 149, § 2 $2^{\circ}$, I, da Constituição, introduzida pela Emenda Constitucional no 33/2001, não alcança a Contribuição Social sobre o Lucro Líquido (CSLL), haja vista a distinção ontológica entre os conceitos de lucro e receita. 6. Vencida a tese segundo a qual a interpretação teleológica da mencionada regra de imunidade conduziria à exclusão do lucro decorrente das receitas de exportação da hipótese de incidência da CSLL, pois o conceito de lucro pressuporia o de receita, e a finalidade do referido dispositivo constitucional seria a desoneração ampla das exportações, com o escopo de conferir efetividade ao princípio da garantia do desenvolvimento nacional (art. $3^{\circ}$, I, da Constituição). 7. A norma de exoneração tributária prevista no art. 149, § 2º I, da Constituição também não alcança a Contribuição Provisória sobre Movimentação ou Transmissão de Valores e de Créditos e Direitos de Natureza Financeira (CPMF), pois o referido tributo não se vincula diretamente à operação de exportação. A exação não incide sobre o resultado imediato da operação, mas sobre operações financeiras posteriormente realizadas. 8. Recurso extraordinário a que se nega provimento.” (RE n 474.132, STF, Pleno, Rel. Min. Gilmar Mendes, Dj-e de 01.12.2010) - Disponível em: <www.stf.jus.br〉. Acesso em: 5 set. 2014. 
entendimento de que as receitas das variações cambiais ativas, por enquadrarem-se no conceito de "receita decorrente de exportação", são imunes à Contribuição ao PIS e à COFINS (Contribuição para Financiamento da Seguridade Social), assim como tal imunidade não se aplica à Contribuição Social sobre o Lucro Líquido (CSLL), uma vez que esse tributo incide sobre o lucro e não sobre a receita nem, tampouco, à Contribuição Provisória sobre Movimentação Financeira (CPMF). Logo, esse tributo incide sobre operações financeiras realizadas posteriormente à exportação e não sobre o resultado imediato da operação.

A segunda delas, por seu turno, encontra-se estampada no artigo 195, inciso II, que assim estabelece:

Art. 195. A seguridade social será financiada por toda a sociedade, de forma direta e indireta, nos termos da lei, mediante recursos provenientes dos orçamentos da União, dos Estados, do Distrito Federal e dos Municípios, e das seguintes contribuições sociais: (Vide Emenda Constitucional $n^{\circ} 20$, de 1998)

[...]

229 "IMUNIDADE - CAPACIDADE ATIVA TRIBUTÁRIA. A imunidade encerra exceção constitucional à capacidade ativa tributária, cabendo interpretar os preceitos regedores de forma estrita. IMUNIDADE EXPORTAÇÃO - RECEITA - LUCRO. A imunidade prevista no inciso I do $\S 2^{\circ}$ do artigo 149 da Carta Federal não alcança o lucro das empresas exportadoras. LUCRO - CONTRIBUIÇÃO SOCIAL SOBRE O LUCRO LÍQUIDO - EMPRESAS EXPORTADORAS. Incide no lucro das empresas exportadoras a Contribuição Social sobre o Lucro Líquido.” (RE n 564.413, STF, Pleno, Rel. Min. Marco Aurélio, DJ-e de 06.12.2010) - Disponível em: <www.stf.jus.br〉. Acesso em: 5 set. 2014.

230“RECURSO EXTRAORDINÁRIO. CONSTITUCIONAL. TRIBUTÁRIO. IMUNIDADE. HERMENÊUTICA. CONTRIBUIÇÃO AO PIS E COFINS. NÃO INCIDÊNCIA. TELEOLOGIA DA NORMA. VARIAÇÃO CAMBIAL POSITIVA. OPERAÇÃO DE EXPORTAÇÃO.

I - Esta Suprema Corte, nas inúmeras oportunidades em que debatida a questão da hermenêutica constitucional aplicada ao tema das imunidades, adotou a interpretação teleológica do instituto, a emprestar-lhe abrangência maior, com escopo de assegurar à norma supralegal máxima efetividade.

II - O contrato de câmbio constitui negócio inerente à exportação, diretamente associado aos negócios realizados em moeda estrangeira. Consubstancia etapa inafastável do processo de exportação de bens e serviços, pois todas as transações com residentes no exterior pressupõem a efetivação de uma operação cambial, consistente na troca de moedas.

III - O legislador constituinte - ao contemplar na redação do art. 149 , $\S 2^{\circ}$, I, da Lei Maior as "receitas decorrentes de exportação" - conferiu maior amplitude à desoneração constitucional, suprimindo do alcance da competência impositiva federal todas as receitas que resultem da exportação, que nela encontrem a sua causa, representando consequências financeiras do negócio jurídico de compra e venda internacional. A intenção plasmada na Carta Política é a de desonerar as exportações por completo, a fim de que as empresas brasileiras não sejam coagidas a exportarem os tributos que, de outra forma, onerariam as operações de exportação, quer de modo direto, quer indireto.

IV - Consideram-se receitas decorrentes de exportação as receitas das variações cambiais ativas, a atrair a aplicação da regra de imunidade e afastar a incidência da contribuição ao PIS e da COFINS.

V - Assenta esta Suprema Corte, ao exame do leading case, a tese da inconstitucionalidade da incidência da contribuição ao PIS e da COFINS sobre a receita decorrente da variação cambial positiva obtida nas operações de exportação de produtos.

VI - Ausência de afronta aos arts. 149, § $2^{\circ}$, I, e 150, § $6^{\circ}$, da Constituição Federal.

Recurso extraordinário conhecido e não provido, aplicando-se aos recursos sobrestados, que versem sobre o tema decidido, o art. 543-B, § $3^{\circ}$, do CPC." (RE 627.815, STF, Pleno, Rel(a). Min(a). Rosa Weber, DJ-e de 25.03.2013) - Disponível em: <www.stf.jus.br〉. Acesso em: 5 set. 2014. 
II - do trabalhador e dos demais segurados da previdência social, não incidindo contribuição sobre aposentadoria e pensão concedidas pelo regime geral de previdência social de que trata o art. 201 ${ }^{231}$; (Redação dada pela Emenda Constitucional nº 20, de 1998).

De acordo com o artigo 195, inciso II da Constituição Federal de 1988, com a nova redação que lhe foi dada pela Emenda Constitucional $n^{\circ}$ 20, de 15 de dezembro de 1998, não haverá a incidência de contribuição social destinada à seguridade social (contribuição previdenciária) sobre os proventos percebidos pelos aposentados e pensionistas do regime geral de previdência.

Já a terceira e última está contida no artigo 203, caput, do mesmo texto normativo e refere-se à imunidade dos necessitados da assistência social oficial ${ }^{232}$ :

Art. 203. A assistência social será prestada a quem dela necessitar, independentemente de contribuição à seguridade social, e tem por objetivos: I - a proteção à família, à maternidade, à infância, à adolescência e à velhice;

Dessa forma, nos termos desse artigo da Constituição Federal de 1988, a União está impedida de exigir contribuição destinada à seguridade social daqueles que necessitarem de assistência social. Sobre essa hipótese imunitória trateremos mais adiante.

\subsubsection{Imunidades tributárias incondicionadas correspondentes às taxas}

Consoante dito acima, via de regra, a imunidade tributária está mais intimamente ligada à figura dos impostos.

Não obstante isso, o legislador de 1988 entendeu por bem inserir no texto constitucional algumas imunidades incondicionadas relacionadas às taxas. São elas:

a) imunidade às taxas no caso de petições endereçadas aos órgãos da Administração Pública em defesa dos interesses dos contribuintes ou em face de ilegalidade ou abuso de poder: artigo 5, inciso XXXIV, alínea "a" ("são a todos assegurados, independentemente de pagamento de taxas: o direito de

\footnotetext{
231 “Art. 201. A previdência social será organizada sob a forma de regime geral, de caráter contributivo e de filiação obrigatória, observados critérios que preservem o equilíbrio financeiro e atuarial, e atenderá, nos termos da lei, a: (Redação dada pela Emenda Constitucional n 20, de 1998)".

${ }^{232}$ Aires Fernandino Barreto e Paulo Ayres Barreto denominam esta espécie de imunidade de "Imunidade de Contribuição à Seguridade Social do Carente e do Desvalido" (BARRETO, Aires Fernandino; BARRETO, Paulo Ayres. Imunidades tributárias: limitações constitucionais ao poder de tributar. 2. ed. São Paulo: Dialética, 2001. p. 102.)
} 
petição aos Poderes Públicos em defesa de direitos ou contra ilegalidade ou abuso de poder");

b) imunidade às taxas em virtude dos pedidos de emissão de certidão para defesa de direitos e para esclarecimentos de situações de interesse pessoal: artigo $5^{\circ}$, inciso XXXIV, alínea "b" ("são a todos assegurados, independentemente de pagamento de taxas: a obtenção de certidões em repartições públicas, para defesa de direitos e esclarecimento de situações de interesse pessoal");

c) imunidade das custas judiciais no caso de propositura de Ação Popular: artigo $5^{\circ}$, inciso LXXIII (“"qualquer cidadão é parte legítima para propor ação popular que vise a anular ato lesivo ao patrimônio público ou de entidade de que o Estado participe, à moralidade administrativa, ao meio ambiente e ao patrimônio histórico e cultural, ficando o autor, salvo comprovada má-fé, isento de custas judiciais e do ônus de sucumbência."). ${ }^{233}$

d) imunidade de taxas para ingresso de Habeas Corpus e Habeas Data: artigo $5^{\circ}$, LXXVII, primeira parte ("são gratuitas as ações de 'habeas-corpus' e 'habeasdata', e, na forma da lei, os atos necessários ao exercício da cidadania”).

De acordo com o trecho retro transcrito, verifica-se serem gratuitos (imunes) os ajuizamentos de Habeas Corpus e Habeas Data. A expressão "na forma da lei” não se refere a esses remédios heroicos, mas sim aos "atos necessários ao exercício da cidadania", de modo que a imunidade das taxas em relação ao ajuizamento de Habeas Corpus e Habeas Data pode ser classificada como “incondicional”, uma vez que não exige o cumprimento de nenhum requisito infraconstitucional para a sua fruição;

e) imunidade das taxas para a celebração de casamento civil: artigo $226, \S 1^{\circ}$ (“o casamento é civil e gratuita a celebração”). Nos termos desse dispositivo constitucional, a celebração do casamento civil é gratuita, o que significa dizer que sobre ele não se pode exigir qualquer espécie de contraprestação pelo serviço público específico e divisível prestado (taxa).

Contudo, como bem explanado por Barreto e Barreto, essa imunidade é limitada, uma vez que não abrange os atos praticados antes da consumação do

${ }^{233}$ Apesar de o artigo $5^{\circ}$, inciso LXXIII dispor que a propositura de Ação Popular está "isenta" do recolhimento de taxas, conforme mencionado no item 2.2 acima, as desonerações fiscais dispostas na Constituição Federal possuem a natureza de imunidade e não de isenção. 
casamento civil, tais como os atos de habilitação e os relativos ao cumprimento de outras formalidades exigidas pela Lei de Registros Públicos ${ }^{234}$; e

f) imunidade das taxas de transporte coletivo urbano aos maiores de 65 anos: artigo 230, $\S 2^{\circ}$ (“aos maiores de sessenta e cinco anos é garantida a gratuidade dos transportes coletivos urbanos").

\subsubsection{Imunidades Condicionadas}

Por sua vez, as imunidades condicionadas só operam plenamente mediante a observância de certas condições definidas em normas infraconstitucionais.

Paulo de Barros Carvalho, em texto intitulado "Imunidades condicionadas e suspensão de imunidades: análise dos requisitos do art. 14 do CTN impostos às instituições de educação sem fins lucrativos" contido na Revista de Direito Tributário $\mathrm{n}^{\circ}$ 99, assim se manifestou acerca das imunidades ditas condicionadas:

As imunidades condicionadas dependem de outras normas que as regulem. Diante da rigidez e exaustividade do sistema constitucional tributário brasileiro, porém, as regras que participam do desenho das competências tributárias não admitem que o legislador infraconstitucional atue de forma que amplie ou limite seu conteúdo e alcance, motivo pelo qual tanto as normas que atribuem competência do ente tributante não podem ser alteradas pelo legislador ordinário. As imunidades condicionadas, em consequência, devem ser regulamentadas por meio de leis infraconstitucionais, sem que, no entanto, haja alterações em seu teor. O que poderá ser objeto de regramento infraconstitucional é apenas a determinação de certas obrigações de fazer e não-fazer, com o intuito de orientar a fruição de algumas hipóteses de imunidade. ${ }^{235}$

Da leitura do trecho acima transcrito, infere-se que, para o pleno gozo das imunidades ditas condicionadas, mister se faz que os seus critérios estejam elencados em normas infraconstitucionais.

Em razão de a Constituição Federal de 1988 restar silente quanto à espécie de lei a ser aplicada com vista à fruição das imunidades ditas condicionadas (lei ordinária ou complementar), doutrina e jurisprudência debruçaram-se sobre esse mote a fim de estabelecer a natureza da norma infraconstitucional aplicável. Após muitos estudos, embates doutrinários

\footnotetext{
${ }^{234}$ BARRETO, Aires F. e BARRETO, Paulo Ayres. Imunidades tributárias: limitações constitucionais ao poder de tributar. 2. ed. São Paulo: Dialética, 2001. p. 100.

${ }^{235}$ CARVALHO, op. cit., p. 10.
} 
e pretorianos, firmou-se o entendimento, tal qual será detidamente demonstrado em tópico específico, de que a lei a que tal dispositivo constitucional se refere é a lei complementar e não a lei ordinária, porque essa espécie normativa (lei complementar) é o único instrumento hábil para regulamentar as "limitações constitucionais ao poder de tributar", dentre as quais se enquadram as imunidades tributárias.

\subsubsection{Imunidade condicionada dos impostos sobre a renda, patrimônio ou} serviços

A Constituição Federal de 1988 trata de somente uma hipótese de imunidade condicionada dos impostos que incidem sobre a renda, patrimônio ou serviços. Essa hipótese está descrita no artigo 150, inciso VI, alínea “c” e corresponde à imunidade concedida aos partidos políticos, inclusive suas fundações, às entidades sindicais de trabalhadores, às instituições de educação e às instituições de assistência social, sem fins lucrativos.

Em relação a essa hipótese de imunidade, fazemos a mesma ressalva feita no concernente às imunidades recíprocas e dos templos de qualquer culto: a de que, apesar de a Carta da República aduzir, expressamente, que serão imunes somente os impostos sobre renda, patrimônio ou serviços, o entendimento majoritário, doutrinário e jurisprudencial, é o de que essa graça aplica-se a todos os impostos incidentes sobre os negócios jurídicos realizados por essas entidades. Sobre essa questão trataremos, de forma delongada, adiante.

Abordaremos a seguir, de forma breve, os aspectos gerais da imunidade dos impostos no tocante aos partidos políticos, inclusive suas fundações, às entidades sindicais de trabalhadores, às instituições de educação e às instituições de assistência social, sem fins lucrativos, já que, como é sabido, o foco do presente trabalho científico está direcionado à imunidade das contribuições sociais das entidades beneficentes de assistência social.

3.1.2.1.1. Imunidade tributária dos partidos políticos, inclusive suas fundações, das entidades sindicais dos trabalhadores, das instituições de educação e de assistência social, sem fins lucrativos

Consoante afirmado linhas atrás, a imunidade tributária aos impostos conferida aos partidos políticos, inclusive as suas fundações, às entidades sindicais dos trabalhadores, às 
instituições de educação e às instituições de assistência social, sem fins lucrativos, está disposta no artigo 150, inciso VI, alínea “c”, da Constituição Federal, que assim prescreve:

Art. 150. Sem prejuízo de outras garantias asseguradas ao contribuinte, é vedado à União, aos Estados, ao Distrito Federal e aos Municípios:

$[\ldots]$

VI - instituir impostos sobre:

[...]

c) patrimônio, renda ou serviços dos partidos políticos, inclusive suas fundações, das entidades sindicais dos trabalhadores, das instituições de educação e de assistência social, sem fins lucrativos, atendidos os requisitos da lei; [...].

Os partidos políticos são pessoas jurídicas de direito privado que possuem por finalidade colaborar para a autenticidade e legitimidade da democracia e do sistema representativo $^{236}$. São, na visão de Aliomar Baleeiro, “instrumentos de governo, entidades fundadas e mantidas exclusivamente para fins públicos, como órgãos imediatos e complementares da organização estatal.",237

Para que uma pessoa jurídica de direito privado seja considerada "partido político", é imperativo preencher os requisitos do artigo 17 da Constituição Federal:

Art. 17. É livre a criação, fusão, incorporação e extinção de partidos políticos, resguardados a soberania nacional, o regime democrático, o pluripartidarismo, os direitos fundamentais da pessoa humana e observados os seguintes preceitos:

I - caráter nacional;

II - proibição de recebimento de recursos financeiros de entidade ou governo estrangeiros ou de subordinação a estes;

III - prestação de contas à Justiça Eleitoral;

IV - funcionamento parlamentar de acordo com a lei.

$\S 1^{\circ}$ É assegurada aos partidos políticos autonomia para definir sua estrutura interna, organização e funcionamento e para adotar os critérios de escolha e o regime de suas coligações eleitorais, sem obrigatoriedade de vinculação entre as candidaturas em âmbito nacional, estadual, distrital ou municipal, devendo seus estatutos estabelecer normas de disciplina e fidelidade partidária. (Redação dada pela Emenda Constitucional n 52 , de 2006)

$\S 2^{\circ}$ - Os partidos políticos, após adquirirem personalidade jurídica, na forma da lei civil, registrarão seus estatutos no Tribunal Superior Eleitoral. $\S 3^{\circ}$ - Os partidos políticos têm direito a recursos do fundo partidário e acesso gratuito ao rádio e à televisão, na forma da lei.

${ }^{236}$ É justamente o que prescreve o artigo $1^{\circ}$, da Lei $\mathrm{n}^{\mathrm{o}}$ 9.096, de 19 de setembro de 1995 , a qual regulamentou o artigo 17, da CF: "O partido político, pessoa jurídica de direito privado, destina-se a assegurar, no interesse do regime democrático, a autenticidade do sistema representativo e a defender os direitos fundamentais definidos pela Constituição Federal".

${ }^{237}$ BALEEIRO, Aliomar; DERZI, Misabel Abreu Machado. Limitações constitucionais ao poder de tributar. ed. atual. Rio de Janeiro: Forense, 2010. p. 564. 
$\S 4^{\circ}-$ É vedada a utilização pelos partidos políticos de organização paramilitar.

Na hipótese de observância desses pressupostos, determinada pessoa jurídica será considerada "partido político". Visando ao gozo da imunidade a que o artigo 150, inciso VI, alínea "c" da Carta da República faz alusão, tal entidade deverá respeitar, além dos requisitos dispostos na Constituição Federal ${ }^{238}$, os contidos em lei. O mesmo se aplica às fundações criadas por esses partidos políticos.

E que lei é essa: ordinária ou complementar?

Entendemos que seja complementar pois, nos termos do artigo 146, inciso II, da Constituição Federal de $1988^{239}$, as "limitações constitucionais ao poder de tributar", gênero do qual as imunidades são espécie, só podem ser regulamentas via lei complementar.

E tal lei complementar atualmente em vigor é o Código Tributário Nacional, o qual, em seu artigo $14^{240}$, dispõe quais são esses pressupostos a serem preenchidos: não distribuir qualquer parcela de seu patrimônio ou de suas rendas, a qualquer título; aplicar integralmente no Brasil seus recursos na manutenção de seu objetivo social; e manter a escrituração de seus livros fiscais. Sobre tais requisitos empenharemos nossos esforços, de forma mais alongada, posteriormente, quando formos tratar da imunidade tributária aplicável às entidades beneficentes de assistência social.

No que concerne às entidades sindicais de trabalhadores, houve uma inovação da Constituição Federal de 1988, pois foi com a promulgação de tal Carta Política que as entidades sindicais passaram a estar sob o manto imunitório.

\footnotetext{
${ }^{238}$ Não possuir fins lucrativos e reverter suas receitas aos seus objetivos sociais.

239 “Art. 146. Cabe à lei complementar:

[...]

II - regular as limitações constitucionais ao poder de tributar; [...]."

240 “Art. 14. O disposto na alínea c do inciso IV do artigo $9^{\circ}$ é subordinado à observância dos seguintes requisitos pelas entidades nele referidas:

I - não distribuírem qualquer parcela de seu patrimônio ou de suas rendas, a qualquer título; (Redação dada pela Lcp n⿳ 104, de 2001)

II - aplicarem integralmente, no País, os seus recursos na manutenção dos seus objetivos institucionais;

III - manterem escrituração de suas receitas e despesas em livros revestidos de formalidades capazes de assegurar sua exatidão.

$\S 1^{\circ} \mathrm{Na}$ falta de cumprimento do disposto neste artigo, ou no $\S 1^{\circ}$ do artigo $9^{\circ}$, a autoridade competente pode suspender a aplicação do benefício.

$\S 2^{\circ}$ Os serviços a que se refere a alínea $\mathrm{c}$ do inciso IV do artigo $9^{\circ}$ são exclusivamente, os diretamente relacionados com os objetivos institucionais das entidades de que trata este artigo, previstos nos respectivos estatutos ou atos constitutivos."
} 
De acordo com o artigo $8^{\circ}$, inciso III da Constituição Federal de $1988^{241}$, uma das principais funcionalidades dos sindicatos de trabalhadores é defender os direitos e interesses individuais ou coletivos da categoria de trabalhadores, considerados hipossuficientes (pessoas carentes ou necessitadas) nas relações travadas com os seus empregadores, de modo que tal regra imunitória se aplica, única e exclusivamente, aos sindicatos de trabalhadores e não aos sindicatos patronais, os quais deverão recolher seus tributos, especialmente os impostos, como toda e qualquer pessoa jurídica de direito privado.

Assim como ocorre com os partidos políticos e suas fundações, para fins de gozo da imunidade dos impostos os sindicatos de trabalhadores deverão respeitar os comandos contidos no artigo 14 do Código Tributário Nacional, sob pena de suspensão da imunidade.

A imunidade concedida aos sindicatos dos trabalhadores estende-se às federações (associação de pelo menos cinco sindicatos) ${ }^{242}$ e às confederações (associação de, pelo menos, três federações $)^{243}$.

\footnotetext{
241 “Art. $8^{\circ}$ É livre a associação profissional ou sindical, observado o seguinte:

$[\ldots]$
}

III - ao sindicato cabe a defesa dos direitos e interesses coletivos ou individuais da categoria, inclusive em questões judiciais ou administrativas; [...]."

242 "Art. 534 - É facultado aos Sindicatos, quando em número não inferior a 5 (cinco), desde que representem a maioria absoluta de um grupo de atividades ou profissões idênticas, similares ou conexas, organizarem-se em federação. (Redação dada pela Lei no 3.265, de 22.9.1957)

$\S 1^{\circ}$ - Se já existir federação no grupo de atividades ou profissões em que deva ser constituída a nova entidade, a criação desta não poderá reduzir a menos de 5 (cinco) o número de Sindicatos que àquela devam continuar filiados. (Incluído pela Lei $\mathrm{n}^{\circ} 3.265$, de 22.9.1957)

$\S 2^{\circ}$ - As federações serão constituídas por Estados, podendo o Ministro do Trabalho, Industria e Comercio autorizar a constituição de Federações interestaduais ou nacionais. (Parágrafo $1^{\circ}$ renumerado pela Lei $\mathrm{n}^{\circ} 3.265$, de 22.9.1957)

$\S 3^{\circ}$ - É permitido a qualquer federação, para o fim de lhes coordenar os interesses, agrupar os Sindicatos de determinado município ou região a ela filiados; mas a união não terá direito de representação das atividades ou profissões agrupadas. (Parágrafo $2^{\circ}$ renumerado pela Lei $n^{\circ} 3.265$, de 22.9.1957)."

243 “Art. 535 - As Confederações organizar-se-ão com o mínimo de 3 (três) federações e terão sede na Capital da República.

$\S 1^{\circ}$ - As confederações formadas por federações de Sindicatos de empregadores denominar-se-ão: Confederação Nacional da Indústria, Confederação Nacional do Comércio, Confederação Nacional de Transportes Marítimos, Fluviais e Aéreos, Confederação Nacional de Transportes Terrestres, Confederação Nacional de Comunicações e Publicidade, Confederação Nacional das Empresas de Crédito e Confederação Nacional de Educação e Cultura.

$\S 2^{\circ}$ - As confederações formadas por federações de Sindicatos de empregados terão a denominação de: Confederação Nacional dos Trabalhadores na Indústria, Confederação Nacional dos Trabalhadores no Comércio, Confederação Nacional dos Trabalhadores em Transportes Marítimos, Fluviais e Aéreos, Confederação Nacional dos Trabalhadores em Transportes Terrestres, Confederação Nacional dos Trabalhadores em Comunicações e Publicidade, Confederação Nacional dos Trabalhadores nas Empresas de Crédito e Confederação Nacional dos Trabalhadores em Estabelecimentos de Educação e Cultura.

$\S 3^{\circ}$ - Denominar-se-á Confederação Nacional das Profissões Liberais a reunião das respectivas federações.

$\S 4^{\circ}-$ As associações sindicais de grau superior da Agricultura e Pecuária serão organizadas na conformidade do que dispuser a lei que regular a sindicalização dessas atividades ou profissões." 
Além dos partidos políticos e suas respectivas fundações, bem como dos sindicatos de trabalhadores, o artigo 150, inciso VI, "c" da Constituição Federal celebra hipótese de imunidade tributária aos impostos às instituições de educação e de assistência social privadas. Essas, embora pessoas jurídicas de direito privado, por auxiliarem o Estado no cumprimento de seus deveres para com a sociedade, são agraciadas como o beneplácito da imunidade tributária. Para tanto, além de exercerem, sem o intuito de lucro, as atividades de colaboração com o Estado, elas devem observar os requisitos do artigo 14 do Código Tributário Nacional para fins de fruição desse benefício.

No que diz respeito às instituições de educação, as atividades a serem exercidas são as mencionadas no artigo 208 da Constituição Federal ${ }^{244}$.

Por sua vez, no que tange às instituições de assistência social, as atividades por elas exercidas que, portanto, ensejam a concessão da imunidade tributária sobre os impostos, são as contidas, em tese, no artigo 203 do mesmo diploma ${ }^{245}$.

\footnotetext{
244 “Art. 208. O dever do Estado com a educação será efetivado mediante a garantia de:

I - educação básica obrigatória e gratuita dos 4 (quatro) aos 17 (dezessete) anos de idade, assegurada inclusive sua oferta gratuita para todos os que a ela não tiveram acesso na idade própria; (Redação dada pela Emenda Constitucional no 59, de 2009) (Vide Emenda Constitucional no 59, de 2009)

II - progressiva universalização do ensino médio gratuito; (Redação dada pela Emenda Constitucional no ${ }^{\circ}$ 14, de 1996)

III - atendimento educacional especializado aos portadores de deficiência, preferencialmente na rede regular de ensino;

IV - educação infantil, em creche e pré-escola, às crianças até 5 (cinco) anos de idade; (Redação dada pela Emenda Constitucional $\mathrm{n}^{\circ}$ 53, de 2006)

$\mathrm{V}$ - acesso aos níveis mais elevados do ensino, da pesquisa e da criação artística, segundo a capacidade de cada um;

VI - oferta de ensino noturno regular, adequado às condições do educando;

VII - atendimento ao educando, em todas as etapas da educação básica, por meio de programas suplementares de material didáticoescolar, transporte, alimentação e assistência à saúde. (Redação dada pela Emenda Constitucional $\mathrm{n}^{\mathrm{0}}$ 59, de 2009)

$\S 1^{\circ}-\mathrm{O}$ acesso ao ensino obrigatório e gratuito é direito público subjetivo.

$\S 2^{\circ}-\mathrm{O}$ não-oferecimento do ensino obrigatório pelo Poder Público, ou sua oferta irregular, importa responsabilidade da autoridade competente.

$\S 3^{\circ}$ - Compete ao Poder Público recensear os educandos no ensino fundamental, fazer-lhes a chamada e zelar, junto aos pais ou responsáveis, pela frequiência à escola."

245 "Art. 203. A assistência social será prestada a quem dela necessitar, independentemente de contribuição à seguridade social, e tem por objetivos:

I - a proteção à família, à maternidade, à infância, à adolescência e à velhice;

II - o amparo às crianças e adolescentes carentes;

III - a promoção da integração ao mercado de trabalho;

IV - a habilitação e reabilitação das pessoas portadoras de deficiência e a promoção de sua integração à vida comunitária;

V - a garantia de um salário mínimo de benefício mensal à pessoa portadora de deficiência e ao idoso que comprovem não possuir meios de prover à própria manutenção ou de tê-la provida por sua família, conforme dispuser a lei."
} 
Essas são, destarte, as considerações gerais a serem feitas em relação à imunidade tributária aos impostos em relação aos partidos políticos e suas respectivas fundações, aos sindicatos de trabalhadores, às instituições de educação e às instituições de assistência social.

Conforme já esclarecido, todas essas entidades não podem possuir fins lucrativos e, para fins de fruição do gozo da imunidade, devem respeitar os parâmetros contidos no artigo 14 do Código Tributário Nacional: a) não distribuir parcela do seu patrimônio, a qualquer título; b) investir seus recursos no País; e c) escriturar corretamente os livros exigidos pela legislação tributária pátria, sob pena de suspensão da imunidade tributária.

Por fim, mas não menos importante, cumpre-nos repisar a ressalva feita linhas atrás, segundo a qual a imunidade tributária aos impostos não se restringe aos incidentes sobre a renda, patrimônio ou serviços, mas sim a todos os impostos, desde que toda a receita auferida por essas entidades seja revertida, sem exceção, aos seus objetivos sociais.

Por conta do objeto do presente trabalho científico, trataremos de forma mais detalhada nos próximos capítulos da imunidade tributária aos impostos e às contribuições sociais destinadas à seguridade social das entidades beneficentes de assistência social, bem como acerca dos requisitos a serem por elas preenchidos a fim de que gozem da exoneração contida na Carta da República de 1988.

\subsubsection{Outras hipóteses de imunidades tributárias condicionadas referentes aos}

\section{impostos}

Afora as imunidades condicionadas relativas a, em tese, os impostos sobre renda, patrimônio ou serviços, a Constituição Federal de 1988 elenca outra hipótese de imunidade condicionada de impostos, que possui campo de abrangência mais restrito, na medida em que só se enquadra nessa hipótese uma única espécie de imposto.

Trata-se da imunidade do Imposto Territorial Rural (ITR) disposta no artigo 153, $\S 4^{\circ}$, inciso II, da Constituição Federal de 1988:

Art. 153. Compete à União instituir impostos sobre:

[...]

VI - propriedade territorial rural;

$[\ldots]$

$\S 4^{\circ} \mathrm{O}$ imposto previsto no inciso VI do caput: (Redação dada pela Emenda Constitucional $\mathrm{n}^{\circ} 42$, de 19.12.2003)

$[\ldots]$ 
II - não incidirá sobre pequenas glebas rurais, definidas em lei, quando as explore o proprietário que não possua outro imóvel; (Incluído pela Emenda Constitucional n ${ }^{\circ} 42$, de 19.12.2003)"

O artigo acima transcrito veda a instituição do ITR sobre pequenas glebas rurais, definidas em lei - é justamente aqui que reside a condicionalidade dessa espécie de imunidade - quando tal gleba for explorada pelo próprio proprietário e desde que o mesmo não possua outro imóvel em seu nome ${ }^{246}$.

Por tratar-se de imunidade condicionada, nos termos do artigo 146, inciso II da Constituição Federal, sua regulamentação só pode se dar por meio de lei complementar ${ }^{247}$.

Por conta da ausência de lei complementar tratando do conceito de "pequena gleba rural", Roque Antonio Carraza menciona que tal propriedade deverá ser considerada aquela que possuir até 50 hectares, de acordo com a dicção extraída do artigo 191 da Carta Magna de 1988:

De qualquer modo, registramos que, enquanto a lei complementar não se ocupar com o assunto, pequena gleba rural, a nosso ver, é a de tamanho não superior a cinquenta hectares. Chegamos a esta conclusão examinando o art. 191 da CF, que, embora não trate especificamente deste tema, guarda uma certa semelhança com o supracitado dispositivo ("aquele que, não sendo proprietário de imóvel rural ou urbano, possua como seu, por cinco anos ininterruptos, sem oposição, área de terra, em zona rural, não superior a cinquenta hectares, tornando-a produtiva por seu trabalho ou de sua família, tendo nela sua moradia, adquiri-lhe a propriedade").

$[\ldots]$

Assim, enquanto não for editada lei específica, pequena gleba rural, para os fins do art. $153, \S 4^{\circ}$, inciso II, da CF, é aquela de tamanho não excedente a cinquenta hectares. ${ }^{248}$

Dessa forma, para fins de fruição dessa imunidade, o proprietário de imóvel rural não deverá possuir outro imóvel e destinar o imóvel rural, que não poderá ter mais do que 50 cinquenta hectares, tal qual visto acima, à sua exploração econômica.

\footnotetext{
${ }^{246}$ É importante mencionar que, na redação original do artigo $153, \S 4^{\circ}$, inciso II da Constituição Federal de 1988, um dos requisitos de fruição dessa imunidade era que o proprietário explorasse sua gleba rural sozinho ou com sua família. Com e edição da Emenda Constitucional $n^{\circ} 42$, tal requisito foi excluído do texto constitucional.

${ }^{247}$ Por esse motivo, entendemos, assim como Roque Antonio Carraza (CARRAZA, Roque Antonio. Curso de Direito Constitucional Tributário. 29. ed. São Paulo: Malheiros, 2013. p. 935) e Aires Fernandino Barreto e Paulo Ayres Barreto (BARRETO, Aires Fernandino; BARRETO, Paulo Ayres. Imunidades tributárias: limitações constitucionais ao poder de tributar. 2. ed. São Paulo: Dialética, 2001. p. 93), que o artigo $2^{\circ}$ da Lei $\mathrm{n}^{\mathrm{o}}$ 9.393, de 16 de dezembro de 1996, sob a pecha de regular a imunidade do ITR estabelecendo a metragem dos imóveis rurais considerados como "pequenas glebas rurais", é inconstitucional, por não ter sido veiculado via lei ordinária e não lei complementar.

${ }^{248}$ CARRAZA, op. cit., p. 934-935.
} 


\subsubsection{Imunidades tributárias correspondentes às Contribuições Sociais}

As únicas hipóteses de imunidades condicionadas das contribuições sociais estão dispostas nos artigos 40, $\S 1^{\circ}$, inciso III e 195, $\S 7^{\circ}$ da Constituição Federal de 1988.

A primeira hipótese de imunidade condicionada das contribuições sociais se refere à impossibilidade de exigência de contribuição previdenciária para os que, após completarem o tempo para aposentadoria, permanecerem em atividade até completar as exigências contidas no artigo 40, $\S 1^{\circ}$, inciso III, da Constituição Federal de 1988:

Art. 40. Aos servidores titulares de cargos efetivos da União, dos Estados, do Distrito Federal e dos Municípios, incluídas suas autarquias e fundações, é assegurado regime de previdência de caráter contributivo e solidário, mediante contribuição do respectivo ente público, dos servidores ativos e inativos e dos pensionistas, observados critérios que preservem o equilíbrio financeiro e atuarial e o disposto neste artigo. (Redação dada pela Emenda Constitucional $\mathrm{n}^{\circ} 41,19.12 .2003$ )

$\S 1^{\circ}$ Os servidores abrangidos pelo regime de previdência de que trata este artigo serão aposentados, calculados os seus proventos a partir dos valores fixados na forma dos $\S \S 3^{\circ}$ e 17: (Redação dada pela Emenda Constitucional $\mathrm{n}^{\mathrm{o}} 41,19.12 .2003$ )

III - voluntariamente, desde que cumprido tempo mínimo de dez anos de efetivo exercício no serviço público e cinco anos no cargo efetivo em que se dará a aposentadoria, observadas as seguintes condições: (Redação dada pela Emenda Constitucional $\mathrm{n}^{\circ}$ 20, de 1998)

a) sessenta anos de idade e trinta e cinco de contribuição, se homem, e cinqüenta e cinco anos de idade e trinta de contribuição, se mulher; (Redação dada pela Emenda Constitucional $\mathrm{n}^{\circ}$ 20, de 1998) (Vide Emenda Constitucional $\mathrm{n}^{\circ} 20$, de 1998)

b) sessenta e cinco anos de idade, se homem, e sessenta anos de idade, se mulher, com proventos proporcionais ao tempo de contribuição. (Redação dada pela Emenda Constitucional no 20, de 1998).

A outra hipótese de imunidade condicionada das contribuições sociais está disposta no artigo 195, $\S 7^{\circ}$, da Constituição Federal de 1988, que assim dispõe:

Art. 195. A seguridade social será financiada por toda a sociedade, de forma direta e indireta, nos termos da lei, mediante recursos provenientes dos orçamentos da União, dos Estados, do Distrito Federal e dos Municípios, e das seguintes contribuições sociais: (Vide Emenda Constitucional $n^{\circ} 20$, de 1998)

$\S 7^{\circ}$ - São isentas de contribuição para a seguridade social as entidades beneficentes de assistência social que atendam às exigências estabelecidas em lei.

Esse dispositivo normativo trata da imunidade das contribuições sociais destinadas à seguridade social usufruída pelas entidades beneficentes de assistência social, desde que 
obedecidos os requisitos firmados em lei. É preciso ressaltar que, apesar de o dispositivo constitucional mencionar a expressão "são isentas", trata-se, em verdade, de imunidade, já que tal exoneração fiscal está contida em norma constitucional e não infraconstitucional. Voltaremos a tratar desse mote no Capítulo V do presente trabalho científico.

Assim, para fazer jus à imunidade a que o artigo $195, \S 7^{\circ}$ da Constituição Federal de 1988 refere-se, é necessário que a entidade, além de ser de assistência social e de não possuir fins lucrativos, tendo por objeto social um ou mais fins a que o artigo 203 da Constituição Federal $^{249}$ menciona, atenda, de forma gratuita, uma parcela de carentes ou necessitados nos campos delineados pelo artigo suso mencionado. Também trataremos melhor da diferença entre "entidade de assistência social" e de "entidade beneficente de assistência social" em tópico específico adiante.

Por ora, cumpre-nos aduzir que também terão direito à imunidade das contribuições sociais destinadas à seguridade social as instituições enquadradas no conceito de entidades beneficentes de assistência social.

\subsubsection{Imunidades tributárias condicionadas correspondentes às taxas}

Diferentemente do que ocorre com as imunidades incondicionadas relacionadas às taxas, que possuem seis representantes contidos na Carta Magna de 1988, as imunidades ditas condicionadas em relação às taxas somente são tratadas pelo legislador constitucional em três oportunidades.

A primeira delas corresponde à imunidade de taxas pela prestação de serviço de assistência jurídica integral e gratuita pelo Estado: artigo $5^{\circ}$, inciso LXXIV (“O Estado prestará assistência jurídica integral e gratuita aos que comprovarem a insuficiência de recursos").

\footnotetext{
249 “Art. 203. A assistência social será prestada a quem dela necessitar, independentemente de contribuição à seguridade social, e tem por objetivos:

I - a proteção à família, à maternidade, à infância, à adolescência e à velhice;

II - o amparo às crianças e adolescentes carentes;

III - a promoção da integração ao mercado de trabalho;

IV - a habilitação e reabilitação das pessoas portadoras de deficiência e a promoção de sua integração à vida comunitária;

$\mathrm{V}$ - a garantia de um salário mínimo de benefício mensal à pessoa portadora de deficiência e ao idoso que comprovem não possuir meios de prover à própria manutenção ou de tê-la provida por sua família, conforme dispuser a lei."
} 
A segunda delas corresponde à imunidade de taxas no caso de registro civil de nascimento e certidão de óbito, aos reconhecidamente pobres, nos termos da lei: artigo $5^{\circ}$, inciso LXXVI ("são gratuitos para os reconhecidamente pobres, na forma da lei: o registro civil de nascimento; e a certidão de óbito").

A terceira e última hipótese de imunidade condicionada aplicada às taxas está contida na segunda parte do artigo $5^{\circ}$, LXXVII. Nos termos desse artigo, não há que se falar em exigência de taxas sobre os atos necessários ao exercício da cidadania, desde que observada a norma infraconstitucional que trata da matéria:

LXXVII - são gratuitas as ações de "habeas-corpus" e "habeas-data", e, na forma da lei, os atos necessários ao exercício da cidadania. 


\section{CAPÍTULO IV - ESCORÇO SOBRE A FIGURA DAS ENTIDADES BENEFICENTES DE ASSISTÊNCIA SOCIAL NO DIREITO BRASILEIRO}

\subsection{A Seguridade Social na Constituição Federal de 1988}

Nos termos do artigo 194 da Constituição Federal de 1998 250 , entende-se por seguridade social o "conjunto integrado de ações de iniciativa dos Poderes Públicos e da sociedade, destinados a assegurar os direitos relativos à saúde, à previdência e à assistência social".

Da singela leitura desse artigo da Constituição Federal de 1988, verifica-se que a seguridade social brasileira é composta pelo tripé: saúde, previdência e assistência social. Tanto é verdade, que a Carta da República de 1988, ao dispor acerca das sessões que compõem o capítulo denominado "Da Seguridade Social", menciona que esse capítulo é composto por quatro sessões: "Disposições Gerais", "Saúde", "Previdência Social", e "Assistência Social".

Em âmbito infraconstitucional, tal segregação também pode ser visualizada, na medida em que o artigo $1^{\circ}$ da Lei $\mathrm{n}^{\circ} 8.212$, de 24 de julho de 1991, menciona que a seguridade social compreende um conjunto integrado de ações praticadas pelo Poder Público e pela sociedade visando a assegurar o direito relativo à saúde, à previdência e à assistência social:

Art. $1^{\circ}$ A Seguridade Social compreende um conjunto integrado de ações de iniciativa dos poderes públicos e da sociedade, destinado a assegurar o direito relativo à saúde, à previdência e à assistência social.

Parágrafo único. A Seguridade Social obedecerá aos seguintes princípios e diretrizes:

a) universalidade da cobertura e do atendimento;

\footnotetext{
250 “Art. 194. A seguridade social compreende um conjunto integrado de ações de iniciativa dos Poderes Públicos e da sociedade, destinadas a assegurar os direitos relativos à saúde, à previdência e à assistência social. Parágrafo único. Compete ao Poder Público, nos termos da lei, organizar a seguridade social, com base nos seguintes objetivos:

I - universalidade da cobertura e do atendimento;

II - uniformidade e equivalência dos benefícios e serviços às populações urbanas e rurais;

III - seletividade e distributividade na prestação dos benefícios e serviços;

IV - irredutibilidade do valor dos benefícios;

$\mathrm{V}$ - eqüidade na forma de participação no custeio;

VI - diversidade da base de financiamento;

VII - caráter democrático e descentralizado da administração, mediante gestão quadripartite, com participação dos trabalhadores, dos empregadores, dos aposentados e do Governo nos órgãos colegiados. (Redação dada pela Emenda Constitucional no 20, de 1998)"
} 
b) uniformidade e equivalência dos benefícios e serviços às populações urbanas e rurais;

c) seletividade e distributividade na prestação dos benefícios e serviços;

d) irredutibilidade do valor dos benefícios;

e) eqüidade na forma de participação no custeio;

f) diversidade da base de financiamento;

g) caráter democrático e descentralizado da gestão administrativa com a participação da comunidade, em especial de trabalhadores, empresários e aposentados.

Por meio da seguridade social, pretende-se proporcionar aos cidadãos e a suas famílias tranquilidade no sentido de que, na hipótese de ocorrência de uma contingência (morte ou invalidez, por exemplo), a qualidade de vida não será afetada por essa fatalidade, já que ele, cidadão, terá condições e meios para a manutenção de suas necessidades básicas e a de seus familiares. A seguridade social deve, portanto, amparar os indivíduos na hipótese de eles não possuírem condições de prover suas necessidades e a de seus familiares, por seus próprios meios.

Para que tais objetivos sejam atingidos, ou seja, a fim de que se possa alcançar o bemestar e a justiça sociais a que o artigo 193 da Constituição Federal de $1988^{251}$ faz referência, faz-se mandatório observar as diretrizes contidas no parágrafo único do artigo 194 da Carta da República: universalidade da cobertura e do atendimento ${ }^{252}$; uniformidade e equivalência dos benefícios e serviços às populações urbanas e rurais $^{253}$; seletividade e distributividade na prestação dos benefícios e serviços ${ }^{254}$; irredutibilidade do valor dos benefícios ${ }^{255}$; equidade na forma de participação no custeio $^{256}$; diversidade da base de financiamento ${ }^{257}$; e caráter

\footnotetext{
251 "Art. 193. A ordem social tem como base o primado do trabalho, e como objetivo o bem-estar e a justiça sociais.".

${ }^{252}$ É a pedra fundamental sobre a qual todas as demais diretrizes da seguridade social se apoiam. Por meio desse princípio e dessa diretriz, todas as contingências da vida (riscos) estão protegidas pela seguridade social, bem como nela todos os cidadãos estão protegidos.

${ }^{253} \mathrm{~A}$ CF procurou igualar os benefícios e serviços concedidos às populações rural e urbana, na medida em que, anteriormente à promulgação dessa Carta Política, havia uma considerável diferença entre a proteção dada aos trabalhadores rurais e aos urbanos. Por meio desse princípio, pretende-se conceder o mesmo sistema de proteção social aos trabalhadores rurais e urbanos.

${ }^{254}$ Por meio da seletividade, objetiva-se permitir tratamento igual a todos, mas preferencialmente aos mais necessitados, na prestação de serviços e na concessão de benefícios. Por seu turno, a distributividade implica na escolha das necessidades e da proteção a ser concedida às pessoas.

${ }^{255}$ Significa dizer que os benefícios concedidos aos indivíduos não poderão sofrer modificações em sua expressão quantitativa (valor monetário) nem, tampouco, em sua expressão qualitativa (valor real).

${ }^{256} \mathrm{O}$ legislador deve definir a justa proporção entre as quotas com que cada ator social deverá contribuir para a seguridade social. Como exemplo, citamos o RAT (Risco de Acidente de Trabalho). Quanto maior for o risco de acidente em determinada atividade, maior será a contribuição a ser dada pelo ator social.

${ }^{257}$ Corresponde à diversificação dos fatos que poderão ensejar a cobrança de contribuições devidas à seguridade social. Como exemplo, podemos citar a exigência de contribuição previdenciária, cota patronal, incidente sobre a folha de salários e a Contribuição ao PIS, incidente sobre o faturamento mensal das pessoas jurídicas.
} 
democrático e descentralizado da gestão administrativa com a participação da comunidade, em especial de trabalhadores, empresários e aposentados ${ }^{258}$.

Assim, a seguridade social corresponde, em verdade, ao gênero do qual a Previdência Social, a Saúde e a Assistência Social são espécies, cada qual possuindo regramento jurídico específico na Constituição Federal de 1988:

- A Saúde oferece uma política social e econômica destinada à redução de riscos de doenças e outras enfermidades, proporcionando ações e serviços para a proteção e recuperação do indivíduo;

- A Previdência Social abrange, em linhas gerais, a cobertura de contingências decorrentes de doenças, invalidez, velhice, desemprego, morte e proteção à maternidade mediante contribuição, concedendo aposentadorias, pensões, etc.

- A Assistência Social, por seu turno, procura atender os hipossuficientes, destinando pequenos benefícios a pessoas que nunca contribuíram para o sistema.

Nas próximas linhas, trataremos de cada um desses alicerces que compõem a seguridade social, sendo certo que os maiores esforços serão envidados em relação à "Assistência Social", já que possui ligação direta como o tema da dissertação ora tratada.

\subsubsection{A Saúde}

Os artigos $196^{259}, 197^{260}, 198^{261}, 199^{262}$ e $200^{263}$, da Constituição Federal de 1988 tratam do primeiro pilar da seguridade social: a Saúde.

\footnotetext{
${ }^{258}$ Por meio dessa diretriz, permite-se a participação dos trabalhadores, empregadores, aposentados e governo na discussão e propostas de aperfeiçoamento e ampliação dos planos e programas de seguridade.

259 “Art. 196. A saúde é direito de todos e dever do Estado, garantido mediante políticas sociais e econômicas que visem à redução do risco de doença e de outros agravos e ao acesso universal e igualitário às ações e serviços para sua promoção, proteção e recuperação."

260 “Art. 197. São de relevância pública as ações e serviços de saúde, cabendo ao Poder Público dispor, nos termos da lei, sobre sua regulamentação, fiscalização e controle, devendo sua execução ser feita diretamente ou através de terceiros e, também, por pessoa física ou jurídica de direito privado.”

261 “Art. 198. As ações e serviços públicos de saúde integram uma rede regionalizada e hierarquizada e constituem um sistema único, organizado de acordo com as seguintes diretrizes:

I - descentralização, com direção única em cada esfera de governo;

II - atendimento integral, com prioridade para as atividades preventivas, sem prejuízo dos serviços assistenciais; III - participação da comunidade.

$\S 1^{\circ}$. O sistema único de saúde será financiado, nos termos do art. 195, com recursos do orçamento da seguridade social, da União, dos Estados, do Distrito Federal e dos Municípios, além de outras fontes. (Parágrafo único renumerado para $\S 1^{\circ}$ pela Emenda Constitucional $n^{\circ} 29$, de 2000)
} 
$\S 2^{\circ}$ A União, os Estados, o Distrito Federal e os Municípios aplicarão, anualmente, em ações e serviços públicos de saúde recursos mínimos derivados da aplicação de percentuais calculados sobre: (Incluído pela Emenda Constitucional $\mathrm{n}^{\mathbf{0}} 29$, de 2000)

I - no caso da União, na forma definida nos termos da lei complementar prevista no $\S 3^{\circ}$; (Incluído pela Emenda Constitucional $\mathrm{n}^{\circ} 29$, de 2000)

II - no caso dos Estados e do Distrito Federal, o produto da arrecadação dos impostos a que se refere o art. 155 e dos recursos de que tratam os arts. 157 e 159, inciso I, alínea a, e inciso II, deduzidas as parcelas que forem transferidas aos respectivos Municípios; (Incluído pela Emenda Constitucional nº 29, de 2000)

III - no caso dos Municípios e do Distrito Federal, o produto da arrecadação dos impostos a que se refere o art. 156 e dos recursos de que tratam os arts. 158 e 159 , inciso I, alínea b e $\S 3^{\circ}$.(Incluído pela Emenda Constitucional $\mathrm{n}^{\circ} 29$, de 2000)

$\S 3^{\circ}$ Lei complementar, que será reavaliada pelo menos a cada cinco anos, estabelecerá:(Incluído pela Emenda Constitucional $\mathrm{n}^{\circ} 29$, de 2000)

I - os percentuais de que trata o $\S 2^{\circ}$; (Incluído pela Emenda Constitucional no 29 , de 2000)

II - os critérios de rateio dos recursos da União vinculados à saúde destinados aos Estados, ao Distrito Federal e aos Municípios, e dos Estados destinados a seus respectivos Municípios, objetivando a progressiva redução das disparidades regionais; (Incluído pela Emenda Constitucional nº 29, de 2000)

III - as normas de fiscalização, avaliação e controle das despesas com saúde nas esferas federal, estadual, distrital e municipal; (Incluído pela Emenda Constitucional no 29, de 2000)

IV - as normas de cálculo do montante a ser aplicado pela União.(Incluído pela Emenda Constitucional n 29, de 2000)

$\S 4^{\circ}$ Os gestores locais do sistema único de saúde poderão admitir agentes comunitários de saúde e agentes de combate às endemias por meio de processo seletivo público, de acordo com a natureza e complexidade de suas atribuições e requisitos específicos para sua atuação. .(Incluído pela Emenda Constitucional no 51 , de 2006)

$\S 5^{\circ}$ Lei federal disporá sobre o regime jurídico, o piso salarial profissional nacional, as diretrizes para os Planos de Carreira e a regulamentação das atividades de agente comunitário de saúde e agente de combate às endemias, competindo à União, nos termos da lei, prestar assistência financeira complementar aos Estados, ao Distrito Federal e aos Municípios, para o cumprimento do referido piso salarial. (Redação dada pela Emenda Constitucional $\mathrm{n}^{\mathrm{o}} 63$, de 2010)

$\S 6^{\circ}$ Além das hipóteses previstas no $\S 1^{\circ}$ do art. 41 e no $\S 4^{\circ}$ do art. 169 da Constituição Federal, o servidor que exerça funções equivalentes às de agente comunitário de saúde ou de agente de combate às endemias poderá perder o cargo em caso de descumprimento dos requisitos específicos, fixados em lei, para o seu exercício. (Incluído pela Emenda Constitucional nº 51, de 2006)."

262 "Art. 199. A assistência à saúde é livre à iniciativa privada.

$\S 1^{\circ}$ - As instituições privadas poderão participar de forma complementar do sistema único de saúde, segundo diretrizes deste, mediante contrato de direito público ou convênio, tendo preferência as entidades filantrópicas e as sem fins lucrativos.

$\S 2^{\circ}$ - É vedada a destinação de recursos públicos para auxílios ou subvenções às instituições privadas com fins lucrativos."

$\S 3^{\circ}$ - É vedada a participação direta ou indireta de empresas ou capitais estrangeiros na assistência à saúde no País, salvo nos casos previstos em lei.

$\S 4^{\circ}-$ A lei disporá sobre as condições e os requisitos que facilitem a remoção de órgãos, tecidos e substâncias humanas para fins de transplante, pesquisa e tratamento, bem como a coleta, processamento e transfusão de sangue e seus derivados, sendo vedado todo tipo de comercialização."

263 "Art. 200. Ao sistema único de saúde compete, além de outras atribuições, nos termos da lei:

I - controlar e fiscalizar procedimentos, produtos e substâncias de interesse para a saúde e participar da produção de medicamentos, equipamentos, imunobiológicos, hemoderivados e outros insumos;

II - executar as ações de vigilância sanitária e epidemiológica, bem como as de saúde do trabalhador;

III - ordenar a formação de recursos humanos na área de saúde;

IV - participar da formulação da política e da execução das ações de saneamento básico;

$\mathrm{V}$ - incrementar em sua área de atuação o desenvolvimento científico e tecnológico;

VI - fiscalizar e inspecionar alimentos, compreendido o controle de seu teor nutricional, bem como bebidas e águas para consumo humano;

VII - participar do controle e fiscalização da produção, transporte, guarda e utilização de substâncias e produtos psicoativos, tóxicos e radioativos;

VIII - colaborar na proteção do meio ambiente, nele compreendido o do trabalho." 
De acordo com o artigo 196 da Constituição Federal de 1988, saúde é direito de todos e dever do Estado. Ela é garantida mediante a aplicação de políticas sociais e econômicas que visem à redução do risco de doenças e outras enfermidades, assim como ao acesso universal e isonômico às ações e aos serviços para sua promoção, proteção e recuperação.

A Saúde é um direito público subjetivo, que pode ser exigido do Estado, o qual, em contrapartida, possui o dever de prestá-la a quem dela necessitar, independentemente de contraprestação a ser dada pelo indivíduo. Constitui, ainda, um dos direitos fundamentais do ser humano.

Nos termos do artigo $3^{\circ}$ da Lei ${ }^{\circ}$ 8080, de 19 de setembro de 1990 (Lei Orgânica da Saúde), com a redação que lhe foi dada pela Lei $n^{\circ} 12.864$, de 2013, a Saúde possui como fatores determinantes e condicionantes à elevação dos níveis de organização social e econômica de um País, dentre outros, a alimentação, a moradia, o saneamento básico, o meio ambiente, a atividade física, o trabalho, a renda, a educação, o transporte, o lazer e o acesso aos bens e serviços essenciais. Por consequência, quanto melhor for a prestação de serviços na área da Saúde, inclusive preventiva, maiores serão os índices de excelência social e econômica de específico País.

Via de regra, os serviços de assistência à saúde devem ser prestados pelo Poder Público, seja federal, estadual, distrital ou municipal ${ }^{264}$. Contudo, a Constituição Federal, em seu artigo 199, faculta às entidades privadas prestarem essa espécie de serviço, de forma complementar ao sistema único de saúde, mediante a celebração de contrato de direito público ou por meio de convênio. As entidades sem fins lucrativos possuem preferência na celebração de tais contratos.

A manutenção da assistência à saúde concedida a toda a população se dá mediante os recursos provenientes dos orçamentos da União, dos Estados, do Distrito Federal e dos Municípios.

\footnotetext{
264 “Art. 23. É competência comum da União, dos Estados, do Distrito Federal e dos Municípios: $[\ldots]$ II - cuidar da saúde e assistência pública, da proteção e garantia das pessoas portadoras de deficiência; [...]."
} 


\subsubsection{A Previdência Social}

Acerca da Previdência Social no direito positivo brasileiro tratam os artigos $201^{265} \mathrm{e}$ $202^{266}$, da Constituição Federal.

A definição de Previdência Social, contida no artigo $1^{\circ}$ da Lei no 8.213 , de 1991, que dispõe sobre os planos de benefícios da Previdência Social, toma por base a sua finalidade: a de "assegurar aos seus beneficiários meios indispensáveis de manutenção, por motivo de incapacidade, desemprego involuntário, idade avançada, tempo de serviço, encargos familiares e prisão ou morte daqueles de que dependiam economicamente". Destarte, a Previdência Social nada mais é do que o segmento da seguridade social ao qual se destina o estabelecimento de uma sistemática de proteção social, mediante contribuição, (diferentemente da Saúde e da Assistência Social), que tem por objetivo proporcionar meios indispensáveis de subsistência ao assegurado e sua família quando ocorrerem as contingências descritas no artigo 201 da Constituição Federal de 1988.

Nesse sentido, vejam-se as considerações de Wágner Balera e Cristiane Mussi:

Previdência é a cobertura dos efeitos de contingências associadas principalmente ao trabalho, resultante de imposição legal e lastreado nas contribuições dos afiliados para seu custeio. Tem, por objetivo, ofertar benefícios aos contribuintes - previdentes - quando, em ocasião futura, sofrerem perda ou redução da capacidade laborativa. ${ }^{267}$

\footnotetext{
265 Art. 201. A previdência social será organizada sob a forma de regime geral, de caráter contributivo e de filiação obrigatória, observados critérios que preservem o equilíbrio financeiro e atuarial, e atenderá, nos termos da lei, a: (Redação dada pela Emenda Constitucional nº 20, de 1998)

I - cobertura dos eventos de doença, invalidez, morte e idade avançada; (Redação dada pela Emenda Constitucional $n^{\circ} 20$, de 1998)

II - proteção à maternidade, especialmente à gestante; (Redação dada pela Emenda Constitucional $\mathrm{n}^{\circ} 20$, de 1998)

III - proteção ao trabalhador em situação de desemprego involuntário; (Redação dada pela Emenda Constitucional $n^{\circ} 20$, de 1998)

IV - salário-família e auxílio-reclusão para os dependentes dos segurados de baixa renda; (Redação dada pela Emenda Constitucional no 20, de 1998)

V - pensão por morte do segurado, homem ou mulher, ao cônjuge ou companheiro e dependentes, observado o disposto no $\S 2^{\circ}$. (Redação dada pela Emenda Constitucional no 20, de 1998)

$\S 1^{\circ}$ É vedada a adoção de requisitos e critérios diferenciados para a concessão de aposentadoria aos beneficiários do regime geral de previdência social, ressalvados os casos de atividades exercidas sob condições especiais que prejudiquem a saúde ou a integridade física e quando se tratar de segurados portadores de deficiência, nos termos definidos em lei complementar. (Redação dada pela Emenda Constitucional $n^{\circ} 47$, de 2005)".

266 “Art. 202. O regime de previdência privada, de caráter complementar e organizado de forma autônoma em relação ao regime geral de previdência social, será facultativo, baseado na constituição de reservas que garantam o benefício contratado, e regulado por lei complementar. (Redação dada pela Emenda Constitucional n ${ }^{\circ} 20$, de 1998)

(...)".

${ }^{267}$ BALERA, Wágner; MUSSI, Cristiane Miziara. Direito previdenciário série concursos públicos. 7. ed. São Paulo: Método, 2010. p. 31.
} 
A Previdência Social consiste, portanto, em uma forma de assegurar ao trabalhador, com fulcro no princípio da solidariedade, benefícios ou serviços quando seja atingido por uma contingência social. Entende-se, assim, que o sistema é baseado na solidariedade humana, em que a população economicamente ativa sustenta a inativa (aposentados). As contingências sociais seriam justamente o desemprego, a doença, a invalidez, a velhice, a maternidade, a morte etc.

A Previdência Social, no Brasil, é composta basicamente por três regimes diferentes. O primeiro deles é o regime geral de previdência, ao qual o artigo 201 da Constituição Federal de 1988, faz referência. Estão inseridos nesse regime todos os trabalhadores da iniciativa privada, seja na condição de empregado, seja na de contribuinte individual.

O regime geral de previdência é regulamentado pelas Leis $n^{\text {os }} 8.212$ e 8.213, ambas de julho de 2001, as quais tratam, em linhas gerais, da organização da seguridade social, do Plano de Custeio; e dos planos de benefícios da Previdência Social, respectivamente. Suas principais características são filiação obrigatória - isto é, todos os segurados que prestam serviços mediante remuneração devem a ela se filiar - e compulsoriedade de sua contribuição - ou seja, todos os segurados que compõem o regime geral da previdência devem a ela contribuir.

O segundo regime de previdência contemplado pelo ordenamento jurídico brasileiro corresponde ao regime próprio dos servidores públicos. Esse regime, assim como ocorre como o previdenciário geral, também possui caráter contributivo e filiação obrigatória. Ele está disposto no artigo 40, da Constituição Federal de $1988^{268}$. Apesar de tal dispositivo constitucional não estar topologicamente disposto na Seção III - "Da Previdência Social”, do Capítulo III ("Da Seguridade Social”), do Título VIII (“Da Ordem Social”), da Constituição Federal de 1988, o mesmo trata dessa subespécie de regime, aplicável exclusivamente aos funcionários públicos da União, dos Estados, do Distrito Federal e dos Municípios.

\footnotetext{
268 “Art. 40. Aos servidores titulares de cargos efetivos da União, dos Estados, do Distrito Federal e dos Municípios, incluídas suas autarquias e fundações, é assegurado regime de previdência de caráter contributivo e solidário, mediante contribuição do respectivo ente público, dos servidores ativos e inativos e dos pensionistas, observados critérios que preservem o equilíbrio financeiro e atuarial e o disposto neste artigo. (Redação dada pela Emenda Constitucional n 41, 19.12.2003)".
} 
Por sua vez, o terceiro e último regime corresponde ao de providência complementar $^{269}$ e está disposto no artigo 202 da Constituição Federal. Esse regime de previdência foi regulamentado pelas Leis Complementares $n^{\text {os }} 108$ e 109, ambas de 2001.

A Lei Complementar $n^{\circ}$ 108, de 29 de maio de 2001, “dispõe sobre a relação entre a União, os Estados, o Distrito Federal e os Municípios, suas autarquias, fundações, sociedades de economia mista e outras entidades públicas e suas respectivas entidades fechadas de previdência complementar". Tal normativo definiu regras para o funcionamento e fiscalização das Entidades Fechadas de Previdência Complementar (EFPC), também conhecidas como Fundos de Pensão, cujos patrocinadores estão ligados aos governos federal, estaduais e municipais. Já a Lei Complementar n 109, também de maio de 2001, “dispõe sobre o regime de previdência complementar", só que da iniciativa privada.

Seja no regime aberto ou no fechado, a participação dos atores nessa espécie de regime de previdência é facultativa e, como a própria nomenclatura subentende, são complementares aos regimes geral ou próprio.

\subsubsection{A Assistência Social}

Assistência social é um termo que designa, genericamente, auxílio, amparo ligando-se ao sentimento de solidariedade pelo próximo e ao exercício da caridade. Ela foi modificando seu perfil ao longo dos anos, passando de uma ideia inicial de caridade e filantropia até constituir-se em um direito social.

No Brasil, a assistência social surgiu vinculada à Igreja Católica e às instituições formadas por membros laicos, mas de fundamentação religiosa. Foi justamente com o intuito de ajudar ao próximo que foram criadas as Santas Casas de Misericórdia ${ }^{270}$.

Entre o período da Era Vargas até meados de 1980, a assistência social era vista como um "favor" do governante à sociedade e não como uma política pública, de responsabilidade

\footnotetext{
${ }^{269}$ A Previdência Privada pode ser aberta ou fechada. Será aberta a que tiver por objetivo instituir e operar planos de benefícios de caráter previdenciário concedidos em forma de renda continuada ou pagamento único, acessível a quaisquer pessoas físicas. A entidade de previdência privada aberta será organizada sob a forma de sociedade anônima. Por sua vez, será fechada quando for acessível apenas a determinadas pessoas ou grupo de pessoas como, por exemplo, empregados da empresa X ou integrantes do Poder Público Federal. Essas entidades serão organizadas mediante a forma de fundação ou sociedades civis, sem fins lucrativos.

${ }^{270}$ A primeira Santa Casa de Misericórdia do Brasil surgiu em 1539, em Olinda. Sua principal função era, basicamente, assistência, pois, além de cuidar dos doentes, prestava-se a abrigar as pessoas, de qualquer faixa etária, abandonadas e marginalizadas - os excluídos do convívio social, os criminosos doentes e os doentes mentais.
} 
do Estado ${ }^{271}$. Tal cenário foi modificado com a promulgação da Constituição Federal de 1988. Foi por meio dessa Carta de República que inúmeras inovações foram trazidas ao campo dos direitos sociais, e uma dessas principais inovações foi justamente "criar" uma Sessão dentro do Capítulo da seguridade social para tratar da "assistência social".

Tais diretrizes estão contidas nos artigos 203 e 204 da Carta Política de 1988, que assim preconizam:

Art. 203. A assistência social será prestada a quem dela necessitar, independentemente de contribuição à seguridade social, e tem por objetivos: I - a proteção à família, à maternidade, à infância, à adolescência e à velhice; II - o amparo às crianças e adolescentes carentes;

III - a promoção da integração ao mercado de trabalho;

IV - a habilitação e reabilitação das pessoas portadoras de deficiência e a promoção de sua integração à vida comunitária;

$\mathrm{V}$ - a garantia de um salário mínimo de benefício mensal à pessoa portadora de deficiência e ao idoso que comprovem não possuir meios de prover à própria manutenção ou de tê-la provida por sua família, conforme dispuser a lei.

Art. 204. As ações governamentais na área da assistência social serão realizadas com recursos do orçamento da seguridade social, previstos no art. 195, além de outras fontes, e organizadas com base nas seguintes diretrizes:

I - descentralização político-administrativa, cabendo a coordenação e as normas gerais à esfera federal e a coordenação e a execução dos respectivos programas às esferas estadual e municipal, bem como a entidades beneficentes e de assistência social;

II - participação da população, por meio de organizações representativas, na formulação das políticas e no controle das ações em todos os níveis.

Parágrafo único. É facultado aos Estados e ao Distrito Federal vincular a programa de apoio à inclusão e promoção social até cinco décimos por cento de sua receita tributária líquida, vedada a aplicação desses recursos no pagamento de: (Incluído pela Emenda Constitucional no 42, de 19.12.2003)

I - despesas com pessoal e encargos sociais; (Incluído pela Emenda Constitucional $\mathrm{n}^{\circ} 42$, de 19.12.2003)

II - serviço da dívida; (Incluído pela Emenda Constitucional $n^{\circ} 42$, de 19.12.2003)

III - qualquer outra despesa corrente não vinculada diretamente aos investimentos ou ações apoiados. (Incluído pela Emenda Constitucional $\mathrm{n}^{\circ}$ 42 , de 19.12.2003).

De acordo com os trechos transcritos acima, constata-se que, via de regra, a assistência social será prestada a quem dela precisar, independentemente da contribuição à seguridade social, e abrange a proteção e o amparo à família, à maternidade, à infância, à adolescência e à velhice. Compreende, também, a promoção da integração ao mercado de trabalho, assim

${ }^{271}$ Cf. CEZNE, 2007, p. 34. 
como a habilitação e a reabilitação de pessoas portadoras de deficiência física. Resumindo, a assistência social preocupa-se com o cidadão desde o seu nascimento até sua morte. Dessa forma, colocam-se dois requisitos relevantes para a definição constitucional da assistência social: atendimento aos carentes e necessitados e a inexistência de contrapartida por parte do beneficiário do atendimento ${ }^{272}$.

Os destinatários da assistência social são os hipossuficientes, não importando a razão pela qual essas pessoas chegaram a tal situação. Basta que não tenham condições de sustentarse para que possam, independentemente da prestação de qualquer contribuição, contar com a assistência a ser prestada pelo Estado ou pela coletividade.

Acerca dessa questão, valemo-nos das considerações de Miguel Horvarth Júnior, para quem

A assistência social é a forma de proteção social que possui as seguintes características: atua após a instalação do estado de necessidade; possui natureza não contributiva; constitui dever do Estado e atua subsidiariamente à proteção previdenciária, ou seja, seus destinatários são pessoas que não estão incluídas no sistema previdenciário, daí afirmar-se que funciona como uma segunda rede de proteção social. ${ }^{273}$

Dessa forma, sempre que qualquer pessoa estiver na condição de carente ou necessitado e carecer de amparo no âmbito da assistência social poderá contar com o Estado ou com a coletividade, os quais terão o dever de auxiliá-la e ampará-la, por meio da prestação, em teoria, dos serviços descritos no artigo 203, da Constituição Federal de 1988.

Estas são, em tese, as áreas em que o Estado e a coletividade poderão atuar visando a auxiliar os hipossuficentes desde o seu nascimento até sua morte.

\footnotetext{
${ }^{272}$ Isso não quer dizer, contudo, que a assistência social pressuponha a impossibilidade de cobrança, daqueles que podem pagar, de qualquer espécie de contrapartida. Cosoante será melhor delineado, a grande diferença entre as entidades de assistência social e as entidades beneficentes de assistência social consiste justamente no quesito contraprestação pelos serviços prestados, pois, enquanto para a configuração da primeira não há a necessidade de prestação de serviço gratuito, mesmo que em favor de uma pequena parcela da população, para a segunda faz-se necessáriodispor à população parcela de seus préstimos de forma gratuita. E essa diferenciação também se reflete na amplitude das hipóteses de concessão das imunidades tributárias. Enquanto as entidades de assistência social somente serão imunes aos impostos, nos termos do artigo 150, inciso VI, "c" da CF, as entidades beneficentes de assistência social, além de gozarem dessa espécie de imunidade, serão "agraciadas" com a imunidade das contribuições destinadas à seguridade social.

${ }^{273}$ HORVATH JÚNIOR, Miguel. Direito Previdenciário. 9. ed. São Paulo: Quartier Latin, 2012. p. 106.
} 


\subsection{Formas de custeio e financiamento da Seguridade Social}

Reiterando o que falamos previamente, a Constituição Federal de 1988, em seu artigo 194, dispõe que a seguridade social compreende um conjunto integrado de ações de iniciativa dos Poderes Públicos e da sociedade visando a assegurar a toda à população os direitos relativos à saúde, à previdência e à assistência social.

A manutenção dessas garantias, todavia, possui um custo. Com a intenção de custeálas, a Carta da República de 1988 estabeleceu duas maneiras de financiamento da seguridade social, nos termos de seu artigo $195^{274}$. A primeira delas se dá por meio de recursos advindos

${ }^{274}$ Art. 195. A seguridade social será financiada por toda a sociedade, de forma direta e indireta, nos termos da lei, mediante recursos provenientes dos orçamentos da União, dos Estados, do Distrito Federal e dos Municípios, e das seguintes contribuições sociais:

I - do empregador, da empresa e da entidade a ela equiparada na forma da lei, incidentes sobre: (Redação dada pela Emenda Constitucional no 20 , de 1998)

a) a folha de salários e demais rendimentos do trabalho pagos ou creditados, a qualquer título, à pessoa física que lhe preste serviço, mesmo sem vínculo empregatício; (Incluído pela Emenda Constitucional no 20, de 1998)

b) a receita ou o faturamento; (Incluído pela Emenda Constitucional no 20, de 1998)

c) o lucro; (Incluído pela Emenda Constitucional nº 20, de 1998)

II - do trabalhador e dos demais segurados da previdência social, não incidindo contribuição sobre aposentadoria e pensão concedidas pelo regime geral de previdência social de que trata o art. 201; (Redação dada pela Emenda Constitucional $n^{\circ} 20$, de 1998)

III - sobre a receita de concursos de prognósticos.

IV - do importador de bens ou serviços do exterior, ou de quem a lei a ele equiparar. (Incluído pela Emenda Constitucional $\mathrm{n}^{\mathrm{o}} 42$, de 19.12.2003)

$\S 1^{\circ}$ - As receitas dos Estados, do Distrito Federal e dos Municípios destinadas à seguridade social constarão dos respectivos orçamentos, não integrando o orçamento da União.

$\S 2^{\circ}$ - A proposta de orçamento da seguridade social será elaborada de forma integrada pelos órgãos responsáveis pela saúde, previdência social e assistência social, tendo em vista as metas e prioridades estabelecidas na lei de diretrizes orçamentárias, assegurada a cada área a gestão de seus recursos.

$\S 3^{\circ}$ - A pessoa jurídica em débito com o sistema da seguridade social, como estabelecido em lei, não poderá contratar com o Poder Público nem dele receber benefícios ou incentivos fiscais ou creditícios. (Vide Medida Provisória $\mathrm{n}^{\circ} 526$, de 2011) (Vide Lei $\mathrm{n}^{\circ} 12.453$, de 2011)

$\S 4^{\circ}$ - A lei poderá instituir outras fontes destinadas a garantir a manutenção ou expansão da seguridade social, obedecido o disposto no art. 154, I.

$\S 5^{\circ}$ - Nenhum benefício ou serviço da seguridade social poderá ser criado, majorado ou estendido sem a correspondente fonte de custeio total.

$\S 6^{\circ}$ - As contribuições sociais de que trata este artigo só poderão ser exigidas após decorridos noventa dias da data da publicação da lei que as houver instituído ou modificado, não se lhes aplicando o disposto no art. 150 , III, 'b'.

$\S 7^{\circ}$ - São isentas de contribuição para a seguridade social as entidades beneficentes de assistência social que atendam às exigências estabelecidas em lei.

$\S 8^{\circ} \mathrm{O}$ produtor, o parceiro, o meeiro e o arrendatário rurais e o pescador artesanal, bem como os respectivos cônjuges, que exerçam suas atividades em regime de economia familiar, sem empregados permanentes, contribuirão para a seguridade social mediante a aplicação de uma alíquota sobre o resultado da comercialização da produção e farão jus aos benefícios nos termos da lei. (Redação dada pela Emenda Constitucional $n^{\circ} 20$, de 1998)

$\S 9^{\circ}$ As contribuições sociais previstas no inciso I do caput deste artigo poderão ter alíquotas ou bases de cálculo diferenciadas, em razão da atividade econômica, da utilização intensiva de mão-de-obra, do porte da empresa ou da condição estrutural do mercado de trabalho. (Redação dada pela Emenda Constitucional no 47, de 2005)

$\S 10$. A lei definirá os critérios de transferência de recursos para o sistema único de saúde e ações de assistência social da União para os Estados, o Distrito Federal e os Municípios, e dos Estados para os Municípios, observada a respectiva contrapartida de recursos. (Incluído pela Emenda Constitucional nº 20, de 1998) 
dos orçamentos da União, dos Estados, do Distrito Federal e dos Municípios (financiamento indireto). Já a segunda forma se dá por meio da arrecadação das contribuições sociais (financiamento direto), espécie autônoma de tributo, tal qual será melhor trabalhado em breve.

Em relação ao financiamento indireto, União, Estados, Distrito Federal e Municípios, quando da elaboração de suas Leis Orçamentárias, devem estabelecer a parcela de recursos a ser transferida e destinada ao financiamento da seguridade social.

Outras formas indiretas de custeio da Seguridade Social estão descritas no artigo 27 da Lei ${ }^{\circ}$ 8.212, de 1991. São elas: multas, a atualização monetária e os juros incidentes sobre as contribuições sociais não recolhidas no prazo previsto pela legislação tributária brasileira; a remuneração percebida por serviços de arrecadação, fiscalização e cobrança prestados a terceiros; receitas advindas da prestação de outros serviços e de fornecimento ou arrendamento de bens; demais receitas patrimoniais, industriais e financeiras; doações, legados, subvenções e outras receitas eventuais; $50 \%$ dos valores obtidos por conta da realização de leilões tendentes a comercializar bens apreendidos em decorrência do tráfico de entorpecentes e da exploração de trabalho escravo; $40 \%$ do resultado dos leilões de quaisquer bens apreendidos pela Receita Federal do Brasil; outras receitas previstas em legislação específica; e 50\% do valor do prêmio do DPVAT recolhido e repassado ao SUS ${ }^{275}$.

Por seu turno, o financiamento direito da seguridade social ocorre mediante a aplicação dos recursos advindos da cobrança das contribuições sociais a que os incisos I a IV, $\S \S 4^{\circ}$ e $8^{\circ}$ da Constituição Federal de 1988 referem-se.

$\S 11$. É vedada a concessão de remissão ou anistia das contribuições sociais de que tratam os incisos I, a, e II deste artigo, para débitos em montante superior ao fixado em lei complementar. (Incluído pela Emenda Constitucional $n^{\circ} 20$, de 1998)

$\S$ 12. A lei definirá os setores de atividade econômica para os quais as contribuições incidentes na forma dos incisos I, b; e IV do caput, serão não-cumulativas. (Incluído pela Emenda Constitucional no 42, de 19.12.2003)

$\S 13$. Aplica-se o disposto no $\S 12$ inclusive na hipótese de substituição gradual, total ou parcial, da contribuição incidente na forma do inciso I, a, pela incidente sobre a receita ou o faturamento. (Incluído pela Emenda Constitucional $n^{\circ} 42$, de 19.12.2003)

275 “Art. 27. Constituem outras receitas da Seguridade Social:

I - as multas, a atualização monetária e os juros moratórios;

II - a remuneração recebida por serviços de arrecadação, fiscalização e cobrança prestados a terceiros;

III - as receitas provenientes de prestação de outros serviços e de fornecimento ou arrendamento de bens;

IV - as demais receitas patrimoniais, industriais e financeiras;

$\mathrm{V}$ - as doações, legados, subvenções e outras receitas eventuais;

VI - 50\% (cinqüenta por cento) dos valores obtidos e aplicados na forma do parágrafo único do art. 243 da Constituição Federal;

VII $-40 \%$ (quarenta por cento) do resultado dos leilões dos bens apreendidos pelo Departamento da Receita Federal;

VIII - outras receitas previstas em legislação específica.

Parágrafo único. As companhias seguradoras que mantêm o seguro obrigatório de danos pessoais causados por veículos automotores de vias terrestres, de que trata a Lei no 6.194 , de dezembro de 1974, deverão repassar à Seguridade Social $50 \%$ (cinqüenta por cento) do valor total do prêmio recolhido e destinado ao Sistema Único de Saúde-SUS, para custeio da assistência médico-hospitalar dos segurados vitimados em acidentes de trânsito." 
As primeiras fontes diretas de financiamento da seguridade social advêm da exigência de contribuições sociais do empregador, da empresa e da entidade a ela equiparada na forma da lei e incidente sobre a folha de salários e demais rendimentos pagos ou creditados, de natureza salarial, aos assegurados empregados ou contribuintes individuais; a receita ou o faturamento; e o lucro.

Ao analisarmos essas primeiras fontes de financiamento da seguridade social, estaremos conjuntamente avaliando "o arquétipo genérico da regra-matriz de incidência das contribuições para a seguridade social, pois o legislador infraconstitucional, ao exercitar a competência tributária, deve observar as determinações constitucionais relativas à instituição do tributo". 276

No que diz respeito à incidência de contribuições sociais destinadas à seguridade social sobre "folha de salários e demais rendimentos do trabalho pagos ou creditados, a qualquer título, à pessoa física que lhe preste serviço, mesmo sem vínculo empregatício"277, cumpre-nos mencionar que tais tributos só incidem sobre as verbas de natureza salarial. Tais verbas são representadas pelas parcelas percebidas pela contraprestação do efetivo serviço prestado pelo empregado ou pelo contribuinte individual, de modo que quaisquer outras parcelas que não representem essa grandeza estarão fora do campo de incidência dessa espécie tributária, tal qual tem, inclusive, sido reconhecido pelo Poder Judiciário ${ }^{278}$.

Acerca das hipóteses sobre as quais pode haver a incidência de contribuição social destinada à seguridade social no que toca aos vencimentos, a título de salário ou contraprestação por serviços prestados pelos contribuintes individuais, trata o artigo 22 da Lei $\mathrm{n}^{\circ}$ 8.212, de 1991. São as chamadas contribuições previdenciárias, cota patronal e RAT (Risco de Acidente de Trabalho) ${ }^{279}$.

\footnotetext{
${ }^{276}$ TOMÉ, Fabiana Del Padre. Contribuições para a Seguridade Social à luz da Constituição Federal. 2. ed. Curitiba: Juruá, 2013. p. 104.

${ }^{277}$ Artigo 195, inciso I, alínea "a”, da Constituição Federal de 1988.

278 "AGRAVO REGIMENTAL NO RECURSO ESPECIAL. TRIBUTÁRIO. ALEGAÇÃO DE QUE TODAS AS VERBAS PAGAS AO EMPREGADO TEM INCIDÊNCIA PREVIDENCIÁRIA. VERBA DECORRENTE DE QUEBRA DE CAIXA. NATUREZA INDENIZATÓRIA. NÃO INCIDÊNCIA DA REFERIDA CONTRIBUIÇÃO. PRECEDENTE: RESP. 942.365/SC, REL. MIN. LUIZ FUX, REL. P/ ACÓRDÃO MIN. TEORI ALBINO ZAVASCKI, DJE 30/05/2011. AGRAVO REGIMENTAL A QUE SE NEGA PROVIMENTO, EM CONFORMIDADE COM O PARECER DO MPF.

1. A verba relativa a quebra de caixa possui natureza indenizatória e não salarial; por essa razão não há incidência de contribuição previdenciária.

2. Agravo Regimental a que se nega provimento, em conformidade do parecer do MPF." (AgRG no RESP n. 1.381.246, STJ, $1^{\text {a }}$ Turma, Rel. Min. Napoleão Nunes Maia Filho, DJ-e de 08.09.2014) - Disponível em: <www.stj.jus.br>. Acesso em: 19 set. 2014.

279 "Art. 22. A contribuição a cargo da empresa, destinada à Seguridade Social, além do disposto no art. 23, é de: I - vinte por cento sobre o total das remunerações pagas, devidas ou creditadas a qualquer título, durante o mês, aos segurados empregados e trabalhadores avulsos que lhe prestem serviços, destinadas a retribuir o trabalho,
} 
A União está autorizada, igualmente, a instituir contribuições sociais destinadas à seguridade social sobre o faturamento ou a receita. Entende-se por faturamento o produto decorrente da realização de operações correspondentes à venda de mercadorias ou à prestação de determinado serviço ${ }^{280}$. Vejam-se, nesse sentido, as considerações de Tércio Sampaio Ferraz, quando da elaboração de Parecer Jurídico sobre a matéria encomendado pela Febraban (Federação Brasileira de Bancos) e pela CONSIF (Confederação Nacional do Sistema Financeiro):

Ora, faturamento como expressão constitucional, é um desses termos que apontam para um conceito enraizado numa prática usual do comércio. Do ponto de vista genético, não se pode deixar de reconhecer que a palavra denota uma prática comercial referente à fatura, isto é, ao ato de faturar ou organizar fatura. Isto é, aquela escrita do vendedor que acompanha as mercadorias, na qual se insere o nome e características da mercadoria, inclusive o preço respectivo (assim, entre outros, Carvalho de Mendonça, em seu: Tratado de Direito Comercial, Rio de Janeiro, 1938). Trata-se, nesse sentido, de uma prática referente a uma técnica documental, que a distingue de outras, como a conta-corrente ou o pedido de mercadorias.

Essa técnica ganhou conceituação doutrinária, de modo que o faturamento de uma empresa passou a referir-se a todas as vendas realizadas em determinado período. O uso comum estendeu, pois, o faturamento de vendas mercantis também a vendas de serviços prestados, com a indicação dos preços respectivos. Assim, o faturamento, que, em sentido denotativo, aponta para o ato de extrair ou formalizar a fatura, conhece uma extensão do seu sentido conotativo, que permite denotar também um rol de vendas de uma empresa.

Essa interpretação tem por base um atributo conotativo do conceito, localizado não no atributo fatura, mas no atributo venda. Entende-se, assim, o entendimento uniforme do STF de faturamento num sentido que alcança, para efeitos fiscais, todas as vendas, mesmo se não acompanhadas de fatura, admitindo, portanto, que ao faturamento se equipare a receita bruta das vendas de mercadorias, de mercadorias e de serviços e de serviços de

qualquer que seja a sua forma, inclusive as gorjetas, os ganhos habituais sob a forma de utilidades e os adiantamentos decorrentes de reajuste salarial, quer pelos serviços efetivamente prestados, quer pelo tempo à disposição do empregador ou tomador de serviços, nos termos da lei ou do contrato ou, ainda, de convenção ou acordo coletivo de trabalho ou sentença normativa. (Redação dada pela Lei $n^{\circ}$ 9.876, de 1999).

II - para o financiamento do benefício previsto nos arts. 57 e 58 da Lei $n^{\circ} 8.213$, de 24 de julho de 1991, e daqueles concedidos em razão do grau de incidência de incapacidade laborativa decorrente dos riscos ambientais do trabalho, sobre o total das remunerações pagas ou creditadas, no decorrer do mês, aos segurados empregados e trabalhadores avulsos: (Redação dada pela Lei n 9.732, de 1998).

a) $1 \%$ (um por cento) para as empresas em cuja atividade preponderante o risco de acidentes do trabalho seja considerado leve;

b) $2 \%$ (dois por cento) para as empresas em cuja atividade preponderante esse risco seja considerado médio;

c) $3 \%$ (três por cento) para as empresas em cuja atividade preponderante esse risco seja considerado grave.

III - vinte por cento sobre o total das remunerações pagas ou creditadas a qualquer título, no decorrer do mês, aos segurados contribuintes individuais que lhe prestem serviços; (Incluído pela Lei $\mathrm{n}^{\circ}$ 9.876, de 1999)."

${ }^{280}$ Esse também é o entendimento do Supremo Tribunal Federal que, ao longo dos tempos, reforçou esse posicionamento (RE n ${ }^{\circ}$ 150.755/PE, STF, Tribunal Pleno, Rel. Min. Sepúlveda Pertence, DJ de 23/11/1992;

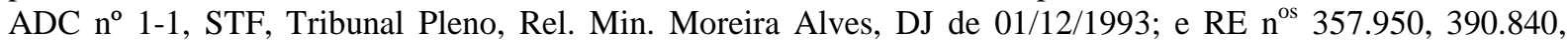
358.273 e 346.084, STF, Tribunal Pleno, Rel. Min. Marco Aurélio, DJ de 09/11/2005). 
qualquer natureza (teor da LC 70/91). Mas que não alcança outros numerários, aqueles que não resultam de venda, como juros, aluguéis, variações monetárias, royalties, lucros e dividendos, descontos obtidos etc. ${ }^{281}$.

Receita, por sua vez, possui conceito mais amplo, englobando

todos os valores que ingressam no caixa, podendo ser constituída, por exemplo, de juros, aluguéis, royalties, lucros distribuídos por outras empresas etc. Diferentemente do faturamento, a receita consiste em qualquer ingresso de valores, decorrente ou não da atividade do contribuinte, apresentando, assim, maior abrangência. ${ }^{282}$

Atualmente, as contribuições sociais destinadas à seguridade social que possuem como base de cálculo a receita ou o faturamento são a COFINS e a Contribuição ao PIS (Programa de Integração Social) ${ }^{283}$, ambas nas modalidades cumulativa ${ }^{284}$ e não cumulativaa ${ }^{285}$.

A outra hipótese de instituição de contribuição social destinada à seguridade social a que o artigo 195, inciso I, da Constituição Federal faz alusão é a que incide sobre o lucro. Sobre a CSLL, subespécie da espécie "contribuição social destinada à seguridade social", trata a Lei $\mathrm{n}^{\mathrm{o}} 7.689$, de 15 de dezembro de 1988, a qual, em seu artigo $2^{\circ}$, estabelece a base de cálculo desse tributo, "o valor do resultado do exercício, antes da provisão para o imposto de renda", ou seja, o lucro contábil ${ }^{286}$.

Outra fonte direta de financiamento da Seguridade Social está contida no inciso II, do artigo 195, da Constituição Federal. Trata-se da cobrança de contribuição social devida pelo trabalhador e demais segurados. A lei $\mathrm{n}^{\circ}$ 8.212, de 1991, em seu artigo 12, define quem são os segurados: empregado, empregado doméstico, contribuinte individual, trabalhador avulso e segurado especial. Portanto, toda e qualquer pessoa física que se enquadrar em uma dessas classes terá de, obrigatoriamente, contribuir com a seguridade social.

\footnotetext{
${ }^{281}$ FERRAZ, Tércio Sampaio. Parecer sobre a incidência de PIS e COFINS sobre as instituições financeiras e companhias de seguro, elaborado em 27 de março de 2007.

${ }^{282}$ TOMÉ, Fabiana Del Padre. Contribuições para a Seguridade Social à luz da Constituição Federal. 2. ed. Curitiba: Juruá, 2013. p. 110.

${ }^{283}$ Esta possui matriz constitucional nos artigos 239 e 195, inciso I, alínea "b" da CF, razão pela qual possui natureza de contribuição social destinada à seguridade social.

${ }^{284}$ Lei no 9.718 , de 27 de novembro de 1998.

${ }^{285}$ Lei $\mathrm{n}^{\mathrm{o}}$ 10.637, de 30 de dezembro de 2002, em relação à Contribuição ao PIS e Lei $\mathrm{n}^{\circ} 10.833$, de 30 de dezembro de 2003, em relação à COFINS.

${ }^{286}$ É importante mencionar a distinção entre o lucro societário ou contábil (base de cálculo da CSLL) do lucro real tributário (base de cálculo do Imposto de Renda Pessoa Jurídica - IRPJ). Enquanto aquele representa o lucro líquido de natureza contábil, este representa o valor apurado após a realização de diversos ajustes - adições, exclusões ou compensações - sobre o lucro contábil apurado.
} 
Também contribuem com o financiamento direto da seguridade social os montantes arrecadados a título de contribuição social sobre "a receita de concursos de prognósticos". Tal figura exacional está disposta no artigo 26, da Lei $\mathrm{n}^{\circ} 8.212^{287}$. Basicamente, sempre que qualquer pessoa for sorteada em loterias, ganhar apostas, inclusive às concernentes às corridas de cavalo, seja em âmbito federal, estadual ou municipal, nascerá a obrigatoriedade de recolhimento de contribuição social destinada à seguridade social, cuja alíquota dependerá da legislação específica. A base de cálculo desse tributo será justamente a renda líquida embolsada, já descontados os impostos incidentes, demais encargos e despesas de cunho administrativo.

Outra fonte direta de financiamento da seguridade social foi incluída em nosso ordenamento jurídico por meio da Emenda Constitucional $n^{\circ} 42$, de 2003, a qual inseriu o inciso IV no artigo 195 da Constituição Federal.

Por intermédio dessa Emenda Constitucional, a União possui competência para instituir contribuição social incidente sobre bens ou serviços importados do exterior. Exercendo sua competência tributária, a União, por meio da Lei $\mathrm{n}^{\circ} 10.865$, de 30 de abril de 2004, instituiu dois novos tributos denominados PIS-Importação e COFINS-importação, os quais, nos termos de seu artigo $7^{\text {288 }}$, possuem como base de cálculo o valor aduaneiro ou o

287 “Art. 26. Constitui receita da Seguridade Social a renda líquida dos concursos de prognósticos, excetuando-se os valores destinados ao Programa de Crédito Educativo. (Redação dada pela Lei n ${ }^{\circ}$ 8.436, de 25.6.92)

$\S 1^{\circ}$ Consideram-se concursos de prognósticos todos e quaisquer concursos de sorteios de números, loterias, apostas, inclusive as realizadas em reuniões hípicas, nos âmbitos federal, estadual, do Distrito Federal e municipal.

$\S 2^{\circ}$ Para efeito do disposto neste artigo, entende-se por renda líquida o total da arrecadação, deduzidos os valores destinados ao pagamento de prêmios, de impostos e de despesas com a administração, conforme fixado em lei, que inclusive estipulará o valor dos direitos a serem pagos às entidades desportivas pelo uso de suas denominações e símbolos.

$\S 3^{\circ}$ Durante a vigência dos contratos assinados até a publicação desta Lei com o Fundo de Assistência SocialFAS é assegurado o repasse à Caixa Econômica Federal-CEF dos valores necessários ao cumprimento dos mesmos."

288 “Art. $7^{\circ}$ A base de cálculo será:

I - o valor aduaneiro, na hipótese do inciso I do caput do art. $3^{\circ}$ desta Lei; ou (Redação dada pela Lei no 12.865 , de 2013)

II - o valor pago, creditado, entregue, empregado ou remetido para o exterior, antes da retenção do imposto de renda, acrescido do Imposto sobre Serviços de qualquer Natureza - ISS e do valor das próprias contribuições, na hipótese do inciso II do caput do art. $3^{\circ}$ desta Lei.

$\S 1^{\circ} \mathrm{A}$ base de cálculo das contribuições incidentes sobre prêmios de resseguro cedidos ao exterior é de $15 \%$ (quinze por cento) do valor pago, creditado, entregue, empregado ou remetido. (Redação dada pela Lei $\mathrm{n}^{\circ}$ 12.249 , de 2010)

$\S 2^{\circ} \mathrm{O}$ disposto no $\S 1^{\circ}$ deste artigo aplica-se aos prêmios de seguros não enquadrados no disposto no inciso $\mathrm{X}$ do art. $2^{\circ}$ desta Lei.

$\S 3^{\circ} \mathrm{A}$ base de cálculo fica reduzida:

I - em 30,2\% (trinta inteiros e dois décimos por cento), no caso de importação, para revenda, de caminhões chassi com carga útil igual ou superior a $1.800 \mathrm{~kg}$ (mil e oitocentos quilogramas) e caminhão monobloco com carga útil igual ou superior a $1.500 \mathrm{~kg}$ (mil e quinhentos quilogramas), classificados na posição 87.04 da Tabela 
"valor pago, creditado, entregue, empregado ou remetido para o exterior", antes da retenção do IIRF acrescido do ISS e do valor das próprias Contribuições mencionadas por essa lei.

A penúltima fonte direta de financiamento da Seguridade Social corresponde à exigência de contribuição social do produtor, do parceiro, do meeiro e do arrendatário rurais, do pescador artesanal e de seus respectivos cônjuges, desde que os mesmos exerçam atividade em regime familiar, sem a existência de empregados permanentes (quando existe a contratação de funcionários, o produtor passa a ser considerado empregador rural, ainda que na condição de pessoa física). A base de cálculo dessa contribuição será o resultado da comercialização de seus produtos.

Por fim, mas não menos importante, a última fonte direta de financiamento da seguridade social possui como gênese o $§ 4^{\circ}$ do artigo 195 da Constituição Federal, o qual trata da competência residual da União para instituir contribuição social destinada à seguridade social. Assim, compete à União, mediante lei complementar, instituir essa nova fonte de custeio da seguridade social, desde que essa exação seja não cumulativa e não possua hipótese de incidência e base de cálculo idênticas às contribuições sociais já expressamente previstas na Carta Política de 1988.

Essas são, portanto, as formas pelas quais a seguridade social é financiada, seja de forma indireta ou direta. É importante consignar que grande parte da receita destinada à seguridade social é representada pelas formas diretas de financiamento, ainda mais se considerarmos que a União não necessita repartir nenhuma fatia de sua arrecadação com Estados, Distrito Federal e Municípios, diferentemente do que ocorre com os impostos por ela arrecadados nos termos dos artigos 167, 168 e 169 da Constituição Federal de 1988.

\subsection{Conceito de Instituição de Assistência Social}

Feitas as digressões a respeito das subáreas que compõem a seguridade social, assim como das fontes diretas e indiretas, de seu financiamento, cumpre-nos tecer algumas

de Incidência do Imposto sobre Produtos Industrializados - TIPI, observadas as especificações estabelecidas pela Secretaria da Receita Federal; e

II - em $48,1 \%$ (quarenta e oito inteiros e um décimo por cento), no caso de importação, para revenda, de máquinas e veículos classificados nos seguintes códigos e posições da TIPI: 84.29, 8432.40.00, 8432.80.00, 8433.20, 8433.30.00, 8433.40.00, 8433.5, 87.01, 8702.10.00 Ex 02, 8702.90.90 Ex 02, 8704.10.00, 87.05 e 8706.00.10 Ex 01 (somente os destinados aos produtos classificados nos Ex 02 dos códigos 8702.10.00 e 8702.90.90)." 
considerações a respeito dos agentes que, juntamente com o Estado, estão aptos a prestar os serviços de assistência social.

Por conta da prestação de serviços na subárea da "assistência social", tais instituições são agraciadas pela imunidade tributária dos impostos a que o artigo 150, inciso VI, alínea "c" da Constituição Federal de 1988 faz remição. Podem, ainda, usufruir da imunidade das contribuições destinadas à seguridade social do artigo $195, \S 7^{\circ}$ da $\mathrm{CF}$, desde que prestem serviços de forma gratuita a parte da população.

Mas qual o conceito de instituição de assistência social? Receberão esta alcunha somente as instituições que se dedicam aos objetivos descritos no artigo 203, da Constituição Federal ou tais objetivos são meramente exemplificativos?

Foi Leopoldo Braga quem procurou limitar o sentido da expressão "instituição" ao de "fundação" ao passo que, para ele, "instituição" representaria a entidade desenvolvedora de atividades estatais $^{289}$. Contudo, doutrina e jurisprudência, ao longo dos anos, afastaram esse entendimento e, atualmente, entende-se por instituição ${ }^{290-291}$ toda e qualquer pessoa jurídica de direito privado que se presta a auxiliar o Estado no seu desiderato social.

Não obstante o legislador constitucional ter utilizado o termo "instituição" no artigo 150, inciso VI, "c" e "entidade" no artigo 195, § 7º ambas são expressões sinônimas, cuja designação corresponde à pessoa jurídica de direito privado que, sem fins lucrativos, auxilia o Estado na tentativa de proporcionar uma vida mais digna à coletividade.

Questão que gera mais discussão do que o conceito de "instituição" ou "entidade" corresponde à abrangência do termo "assistência social"; se a "assistência social" teria seus objetivos traçados, de forma taxativa, no artigo 203 ou se tal lista seria meramente exemplificativa.

\footnotetext{
${ }^{289}$ Cf., BALEEIRO;DERZI, 2010, p. 532.

${ }^{290}$ De acordo com as lições de Regina Helena Costa, "instituições são aquelas entidades formadas com o propósito de servir à coletividade, colaborando com o Estado ao suprir suas deficiências. São pessoas de Direito Privado que exercem, sem fim lucrativo, atividades de colaboração com o Estado em funções cujo desempenho é, em princípio, atribuição deste. Objetiva-se, assim, impedir sejam tais entidades oneradas por via de impostos." (COSTA, Regina Helena. Imunidades tributárias - teoria e análise da jurisprudência do STF. 2. ed. São Paulo: Malheiros, 2006. p. 173.).

${ }^{291}$ Esse também é o entendimento de Clélio Chiesa, para quem "o termo instituições é empregado pelo texto constitucional, a nosso ver, em sentido amplo, compreendendo todo tipo de pessoa jurídica, e não somente as fundações. De sorte que toda pessoa jurídica criada com a finalidade de proporcionar educação e assistência social sem caráter mercantil fará jus aos benefícios da referida imunidade. O objetivo foi dar ênfase ao fim colimado com a pessoa jurídica e não ao seu tipo. Vale dizer, se é sem fins lucrativos, seja fundação, sociedade ou associação, estão acobertadas pelos benefícios da imunidade contemplada no art. 150, VI, 'c', da Constituição Federal." (CHIESA, Clélio. Imunidade tributária das instituições sem fins lucrativos no tocante a impostos e contribuições destinadas a financiar a Seguridade Social. In: SCHOUERI, Luís Eduardo (coord.). Direito tributário - homenagem a Paulo de Barros Carvalho. São Paulo: Quartier Latin, 2008. p. 401-424 (p. 403$)$ ).
} 
Antecipamos que o Supremo Tribunal Federal e o autor do presente trabalho científico entendem que "assistência social" abarca hipóteses outras além das contidas no artigo 203 da Constituição Federal de 1988. Para os adeptos de nossa corrente, o artigo 203 deve ser

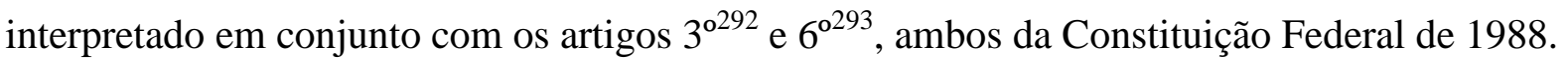

Isso porque o artigo $3^{\circ}$ da Constituição Federal, especialmente o seu inciso III, prescreve que um dos objetivos da República Federal do Brasil é "erradicar a pobreza e a marginalização e reduzir as desigualdades sociais e regionais". A fim de alcançar esse objetivo, o Estado necessita do auxílio das instituições sem fins lucrativos, as quais adotarão todas as medidas protetivas em favor da população, mesmo que não estejam contidas no artigo 203 da Constituição Federal de 1998, visando à redução ou eliminação das desigualdades, carências e injustiças.

Dessa forma, serão consideradas instituições de assistência social as sociedades de direito privado que, sem fins lucrativos, fazendo as vezes do Estado, prestarem quaisquer espécies de serviços de relevante interesse público, tais como "a educação, o acesso à cultura, a assistência social, em suas diversas modalidades (médica, hospitalar, odontológica, jurídica etc) ${ }^{, 294}$.

É justamente por esse motivo que Sacha Calmon Navarro Côelho e Derzi aduzem que “é irrelevante que os serviços prestados pela instituição de assistência social imune sejam de natureza alimentar, cultural, educacional, previdenciária, habitacional ou de saúde. O que interessa é que tenham caráter assistencial, ou seja, sejam vertidos em favor de necessitados e, portanto, gratuitamente, ainda que cobrados de outros ou custeados por outros". 295-296

Portanto, é irrelevante, para fins de configuração da abrangência do conceito de instituição de assistência social, que os serviços por ela prestados sejam somente os

\footnotetext{
${ }^{292} \mathrm{O}$ artigo $3^{\circ}$ trata dos objetivos fundamentais do Brasil, dentre os quais se encontram a erradicação da pobreza e da marginalização, a redução das desigualdades sociais e regionais e a promoção do bem de toda a sociedade, independentemente de origem, sexo, cor, idade e quaisquer outras diferenças entre a população:“Art. $3^{\circ}$ Constituem objetivos fundamentais da República Federativa do Brasil: I - construir uma sociedade livre, justa e solidária; II - garantir o desenvolvimento nacional; III - erradicar a pobreza e a marginalização e reduzir as desigualdades sociais e regionais; IV - promover o bem de todos, sem preconceitos de origem, raça, sexo, cor, idade e quaisquer outras formas de discriminação".

${ }^{293}$ Por sua vez, o artigo $6^{\circ}$, da Constituição Federal, com a redação que lhe foi dada pela Emenda Constitucional $\mathrm{n}^{\circ}$ 64, de 2010, dispõe que são direitos sociais "a educação, a saúde, a alimentação, o trabalho, a moradia, o lazer, a segurança, a previdência social, a proteção à maternidade e à infância, a assistência aos desamparados".

${ }^{294}$ COSTA, Regina Helena. Imunidades tributárias - teoria e análise da jurisprudência do STF. 2. ed. São Paulo: Malheiros, 2006. p. 174.

${ }^{295}$ CÔELHO, Sacha Calmon Navarro; DERZI, Misabel Abreu Machado. A Imunidade Tributária da Caixa de Assistência da Ordem dos Advogados - OAB. Revista Dialética de Direito Tributário, São Paulo, n. 102, p. 145160, 2010. p. 155.

296 Em sentido idêntico: BARRETO, Aires Fernandino; BARRETO, Paulo Ayres. Imunidades tributárias: limitações constitucionais ao poder de tributar. 2. ed. São Paulo: Dialética, 2001. p. 108.
} 
relacionados aos objetivos contidos no artigo 203 da Constituição. O que realmente importa é que o destinatário esteja totalmente protegido, independentemente de o serviço que lhe está sendo prestado estar ou não contido em tal dispositivo. O que a Constituição Federal visa é justamente a proteger a dignidade da pessoa humana, não importando a denominação que o serviço prestado pela instituição de assistência social receba.

Wagner Balera, ao analisar o caráter taxativo ou não do artigo 203 da Constituição Federal, assim se manifestou:

Pensamos que a numeração não é taxativa. Ali estão elencadas prioridades que servem como um programa de ação para os governantes. Outros programas poderão surgir e estes, desde que sirvam para a superação das desigualdades e para a erradicação da pobreza, deverão merecer atenção e estarão agregados, como complemento, ao amplo programa de ação ali desenhado."297

Ademais, as instituição de assistência social buscam implementar os direitos sociais (educação, saúde, trabalho, lazer, segurança, previdência social, proteção à maternidade e à infância, assistência aos desamparados) a que o artigo $6^{\circ}$, da Constituição Federal alude.

Ao proteger essa gama infindável de direitos sociais, a Constituição Federal pretendeu auxiliar as pessoas desde o seu nascimento, passando pela sua fase educacional, até alcançar a velhice e, posteriormente, a morte.

O Supremo Tribunal Federal, quando do julgamento do pedido de concessão de medida liminar formulado nos autos da ADIN $2.028^{298}$, manifestou-se no sentido de que a assistência social é muito mais ampla do que a contida no artigo 203 da Constituição Federal de 1988.

Nos termos do voto de seu Relator, Ministro Moreira Alves, tendo em vista o caráter social da Constituição Federal de 1988, pretendeu-se assegurar às pessoas carentes a concessão de todos os meios de satisfação de suas necessidades vitais, de modo que essa proteção deve transitar por todas as áreas que tratam dos benefícios e serviços prestados a "quem necessitar", ou seja, às pessoas que necessitarem de saúde, educação e de assistência social stricto sensu ${ }^{299}$ :

\footnotetext{
${ }^{297}$ BALERA, op. cit., 114.

${ }^{298}$ ADI no 2.028-5, STF, Pleno, Rel. Min. Moreira Alves, DJ de 11.11.1999.

${ }^{299}$ De acordo com Ives Gandra da Silva Martins, a Seguridade Social, tal qual disposta na Constituição Federal de 1988, é composta pela assistência social lato sensu e a stricto sensu. A primeira é integrada pela previdência, saúde e assistência social propriamente dita. Já a segunda hospeda os serviços ligados aos objetivos do artigo
} 
Com efeito, as próprias informações do Exmo. Sr. Presidente da República, com relação ao conceito de assistência social, invocam lição de CESARINO JÚNIOR, segundo a qual "a forma típica de assistência social é aquela destinada a assegurar os meios de vida aos indigentes", e por isso, para oporse a assistência social à previdência, "podemos definir o direito Assistencial como a parte do Direito Social relativa à concessão aos hipossuficientes dos meios de satisfação de suas necessidades vitais, sem qualquer contraprestação de sua parte". E entre essas necessidades se encontram as relativas à saúde e também à educação, esta como meio para atender a objetivos visando pelo artigo 203, como o amparo às crianças e adolescentes carentes e à promoção da integração no mercado de trabalho.

Do exame sistemático da Constituição, verifica-se que a Seção relativa à Assistência Social não é exauriente do que se deve entender como Assistência Social, pois, além de não se referir a carentes em geral, mas apenas a família, crianças, adolescentes, velhos e portadores de deficiência sem sequer exigir de todos estes que sejam carentes, preceitua, em seu artigo 203, que ela se fará independentemente de contribuição à seguridade social, a indicar que será gratuita, o que só se compatibilizará com o disposto no parágrafo único do artigo 149 - que permite que os Estados, o Distrito Federal e os Municípios instituam contribuição cobrada de seus servidores para o custeio, em benefício destes, de sistemas de previdência e assistência social - se se entender que, para a Constituição, o conceito de assistência social é mais amplo não só do doutrinário, mas também do adotado pelo artigo 203 para a disciplina específica prevista nele e no dispositivo que se lhe segue.

Note-se, ademais, que, regulamentando as exigências necessárias para o gozo da imunidade prevista no artigo 195 , parágrafo $7^{\circ}$, da Constituição, não teria sentido pretendesse essa lei, no mesmo dispositivo regulamentador da imunidade, fazer a distinção entre entidades beneficentes de assistência social e entidades beneficentes educacionais ou de saúde, para estabelecer, sem declará-lo expressamente, que aquelas teriam direito à imunidade, ao passo que a estas se concedia apenas isenção.

[...] o que implica dizer, para não se cair num contra-senso, que as que praticam de forma exclusiva e gratuita atendimento a pessoas carentes se incluem nas a que se refere o parágrafo $3^{\circ}$ que foi acrescentado ao artigo 55 da Lei 8.212, ao dizer que "para os fins desse artigo (e, portanto, para a obtenção da imunidade), entende-se por assistência social beneficente a prestação gratuita de benefícios e serviços (e, portanto, de educação e de saúde também) a quem dela necessitar".

Esse conceito mais lato de assistência social - e que é admitido pela Constituição - é o que parece deva ser adotado para a caracterização dessa assistência prestada por entidades beneficentes, tendo em vista o cunho nitidamente social de nossa Constituição. 
Mais recentemente, o Supremo Tribunal Federal, nos autos do Recurso Extraordinário $n^{\circ}$ 632.941, que trata da questão da extensão da imunidade do artigo $195, \S 7^{\circ}$ da Constituição à Contribuição ao PIS, reiterou o seu entendimento de que a imunidade dos impostos do artigo 150, inciso VI, alínea “c”, bem como a própria imunidade do artigo 195, § $7^{\circ}$ abrange toda e qualquer instituição sem fins lucrativos que presta qualquer serviço tendente a ajudar os hipossuficientes, independentemente de tais préstimos estarem ou não contidos nos objetivos do artigo 203 da Carta Política.

Nesse sentido, vejam-se as considerações do Ministro Luiz Fux, relator desse Recurso Extraordinário:

\begin{abstract}
A expressão contida no art. 150, VI, c, CF-88, que estipula a imunidade das instituições de assistência social - aplicável por analogia à expressão entidades beneficentes de assistência social contida no art. 195, § $7^{\circ}, \mathrm{CF}-88$ - não está jungida ao conceito de assistência social contido no art. 203, da CF-88. Podendo, portanto, estender-se às instituições de assistência stricto sensu de educação, de saúde e de previdência social, esta seguindo as premissas fixadas no verbete retrocitado.

$[\ldots]$

O art. 195, § $7^{\circ}, \mathrm{CF}-88$, ainda que não inserido no capítulo do Sistema Tributário Nacional, mas explicitamente incluído topograficamente na temática da seguridade social, trata, inequivocamente, de matéria tributária. Porquanto, ubi eadem ratio ibi idem jus, podendo, bem por isso, estender-se às instituições de assistência social stricto sensu de educação, de saúde e de previdência social, máxime na medida em que restou superada a tese de que este artigo só se aplica às entidades que tenham por objetivo tão somente as disposições do art. 203 da CF-88 (MC ADIN n. 2028-5, Rel. Ministro Moreira Alves, Pleno, DJ 16.6.2000)".
\end{abstract}

Postas essas considerações, entendemos já ser possível estabelecer um conceito de “instituição de assistência social”. No nosso entendimento, trata-se de entidade que, sem qualquer intuito lucrativo, presta serviços à população que deles necessitar, buscando promover a erradicação da pobreza e a integração ou reintegração do indivíduo na sociedade por meio de ações protetoras relacionadas não somente às áreas da assistência social stricto sensu, mas também a todo o campo em que houver relevante interesse público, na medida em que essas instituições, conforme visto acima, auxiliam o Estado no seu desiderato social.

\title{
4.4. Conceito de Entidade Beneficente de Assistência Social
}

Tal qual visto no tópico acima, sempre que determinada instituição de direito privado, sem fins lucrativos, prestar serviços de relevante interesse público à sociedade, fará jus à 
imunidade dos impostos a que a Constituição Federal de 1988 faz referência em seu artigo 150, inciso VI, alínea “c”.

Contudo, existem outras entidades que se enquadram em outra espécie de imunidade, além da descrita acima. Trata-se da imunidade às contribuições sociais destinadas à seguridade social.

Para que determinada pessoa jurídica de direito privado possa usufruir dessa hipótese imunitória, cumpre-lhe, afora ser instituição de assistência social, enquadrar-se no conceito de entidade beneficente.

Entidade beneficente é aquela que presta serviços de forma gratuita. Não se trata de gratuidade total, na medida em que basta que parcela de seus serviços seja destinado aos carentes e necessitados (hipossuficientes), ou seja, aqueles que não possuem condições de se autossustentar, para que determinada entidade seja considerada instituição beneficente de assistência social.

Nesse sentido, vejam-se as considerações de Aires Fernandino Barreto e Paulo Ayres Barreto, para os quais as entidades beneficentes de assistência social possuem uma característica a mais em relação as entidades de assistência social: prestam serviços de forma gratuita $^{300}$ :

Dessas disposições é possível extrair, no entanto, que instituição de
assistência social é aquela cujo objeto social, descrito no respectivo estatuto,
envolve um ou mais dos fins públicos referidos pela Constituição, isto é, o
de colaborar com o Estado na realização de uma obra social para a
coletividade.
Mais que entidade de assistência social, tem ela que ser beneficente. Esse
vocábulo tem por fim deixar patente que a instituição deve assistir carentes e
necessitados, provendo uma ou algumas de suas (destes) necessidades
(assistência médica, odontológica, jurídica). Ter atuação que vise à proteção
da família ou amparo à velhice, a crianças e a adolescentes carentes.
Colaborar com o Estado em outros campos, seja promovendo a integração de
pessoas ao mercado de trabalho, seja viabilizando a habilitação e a
reabilitação das pessoas portadoras de deficiência, seja proporcionando sua
integração à vida comunitária.
Para a imunidade de impostos, basta tratar-se de entidade sem fins
lucrativos, mas para ter jus à imunidade das contribuições relativas à
seguridade social, é preciso mais. É necessário que, ademais disso, colabore

${ }^{300}$ Regina Helena Costa também acentua que a característica que distingue a entidade de assistência social da entidade beneficente de assistência social corresponde à gratuidade. Enquanto que as instituições de assistência social não necessitam prestar seus serviços de forma gratuita, o mesmo não ocorre em relação às instituições beneficentes de assistência social, as quais, necessariamente, a fim de obter tal denominação, deverão prestar serviços de forma gratuita. Nunca é demais mencionar que ambas não podem ter fins lucrativos (COSTA, Regina Helena. Imunidades tributárias - teoria e análise da jurisprudência do STF. 2. ed. São Paulo: Malheiros, 2006. p. 223). 
com o Estado no campo da assistência social, atendendo gratuitamente uma parcela de carentes ou de necessitados, nos campos antes referidos. É instituição de assistência social a que dedicar-se a um ou alguns desses misteres. E é beneficente aquela que dedicar parte dessas atividades ao atendimento gratuito de carentes e de desvalidos." ${ }^{301}$

Esse também é o entendimento do Supremo Tribunal Federal. Para comprovar tal assertiva, valemo-nos, uma vez mais, da decisão proferida nos autos da ADIN n ${ }^{\circ}$ 2.028, de Relatoria do Ministro Moreira Alves:

É evidente que tais entidades, para serem beneficentes, teriam de ser filantrópicas (por isso, o inciso II do artigo 55 da Lei 8.212/91, que continua em vigor, exige que a entidade "seja portadora do Certificado ou do Registro de Entidade de Fins Filantrópicos, fornecido pelo Conselho Nacional de Serviço Social, renovado a cada três anos"), mas não exclusivamente filantrópica, até porque as que o são não o são para o gozo de benefícios fiscais, e esse benefício concedido pelo $\S 7^{\circ}$ do artigo 195 não o foi para estimular a criação de entidades exclusivamente filantrópicas, mas, sim, das que, também sendo filantrópicas, sem o serem integralmente, atendessem às exigências legais para que se impedisse que qualquer entidade, desde que praticasse atos de assistência filantrópica a carentes, gozasse da imunidade, que é total, de contribuição para a seguridade social, ainda que não fosse reconhecida como de utilidade pública, seus dirigentes tivessem remuneração ou vantagens, ou se destinassem elas a fins lucrativos. Aliás, são essas entidades - que, por não serem exclusivamente filantrópicas, têm melhores condições de atendimento aos carentes a quem os prestam - que devem ter sua criação estimulada para o auxílio ao Estado nesse setor, máxime em época em que, com a atual, são escassas as doações para a manutenção das que se dedicam exclusivamente à filantropia."

De acordo com o trecho acima transcrito, a fim de que determinada instituição enquadre-se no conceito de "entidade beneficente de assistência social" e possa, por conseguinte, gozar da imunidade não só aos impostos, mas também às contribuições sociais destinadas à seguridade social, dita entidade deverá praticar a filantropia ${ }^{302}$ de forma parcial e não total, na medida em que somente parte de seus préstimos deverá ser destinado à população carente.

Dessa forma, será considerada entidade beneficente de assistência social a instituição que, sem fins lucrativos, embora exercendo suas atividades mediante remuneração aos que possam por elas pagar, prestar serviços aos hipossuficientes visando ao atendimento de suas

${ }^{301}$ BARRETO, Aires Fernandino; BARRETO, Paulo Ayres. Imunidades tributárias: limitações constitucionais ao poder de tributar. 2. ed. São Paulo: Dialética, 2001. p. 108-109.

${ }_{302}$ De acordo com o Dicionário Michaelis de língua portuguesa, entende-se por filantropia, de origem grega philanthropía, o amor à Humanidade, o humanitarismo, a caridade (MICHAELIS. Moderno Dicionário da Língua Portuguesa. São Paulo: Melhoramentos, 2002. p. 957). 
necessidades básicas e vitais, sem que deles haja a cobrança de qualquer montante pela prestação de tais préstimos.

Enquadrando-se nesse conceito, dita instituição, além de usufruir da imunidade dos impostos, nos termos do artigo 150, inciso VI, alínea "c" da Constituição, gozará da imunidade tributárias às contribuições sociais destinadas à seguridade social.

\subsection{Distinção entre entidade de assistência social, entidade beneficente de assistência social e entidade filantrópica}

Antes de traçarmos as diferenças entre instituições de assistência social, entidades beneficentes de assistência social e entidades filantrópicas, cumpre-nos aduzir que existe uma característica comum entre elas: todas, sem exceção, não possuem finalidade lucrativa. Essa é uma das condições sine qua non para que determinadas pessoas jurídicas de direito público possam receber a denominação de "instituição de assistência social", de "entidade beneficente de assistência social" e de "entidade filantrópica".

Dessa forma, podemos dizer, então, que essas três espécies de pessoas jurídicas de direito privado compõem o gênero das instituições sem fins lucrativos, cujas espécies são as instituições de assistência social, as entidades beneficentes de assistência social e as entidades filantrópicas.

De forma direta e objetiva, na medida em que os conceitos de "instituição de assistência social" e de "entidades beneficentes de assistência social" já foram abordados nos tópicos que antecedem o presente, entende-se por instituição de assistência social a pessoa jurídica de direito privado, sem fins lucrativos, que presta serviços de relevante interesse público a quem deles necessitar, independentemente de os mesmos possuírem os seus objetivos descritos no artigo 203 da Constituição Federal de 1988. As entidades que se enquadrarem nesse conceito e observarem os requisitos estabelecidos em lei complementar, tal qual será demonstrado no próximo capítulo, usufruirão da imunidade aos impostos a que o artigo 150, inciso VI, alínea “c” da Constituição Federal faz referência.

Por sua vez, se determinada entidade, também sem fins lucrativos, além de prestar serviços de relevante interesse público, fizé-lo de forma gratuita a pessoas carentes e necessitadas, enquadrar-se-á no conceito de entidade beneficente de assistência social. Essa entidade, desde que também preencha os requisitos contidos em lei complementar, afora gozar da imunidade aos impostos nos termos do artigo 150, inciso VI, alínea "c", da 
Constituição Federal de 1988, terá direito à fruição da imunidade às contribuições sociais destinadas à seguridade social, nos exatos termos do artigo $195, \S 7^{\circ}$ da Constituição Federal de 1988.

Por fim, entende-se por entidades filantrópicas aquelas que se dedicam à filantropia. Tais entidades caracterizam-se por serem associações que desenvolvem atividade econômica sem exigir contraprestação, na medida em que vivem de doações. "Por não terem fins lucrativos e desenvolverem atividade econômica não remunerada, essas associações praticam a filantropia."303

Por prestarem serviços de forma gratuita, sem exigir qualquer espécie de contraprestação por isso, as entidades filantrópicas não poderão figurar no polo passivo da relação jurídica, já que lhes falece capacidade contributiva, porquanto todos os seus bens e receitas advém de doações. Não possuindo os serviços prestados preço, não há nem que se falar em hipótese de imunidade tributária.

Corroborando esse entendimento ${ }^{304}$, transcrevemos os ensinamentos de Aires F. Barreto e Paulo Ayres Barreto:

Como lembra Sua Excelência, é despropositado pretender que os serviços prestados por instituições de educação e de assistência social sejam sempre gratuitos. Esse despropósito fica mais visível se tomarmos em conta fato singelo: se os serviços prestados por essas instituições fossem (sempre) todos gratuitos, de nada valeria a imunidade. Fossem gratuitos, não teriam preços; não tivessem preço, jamais poderiam ser objeto de tributação por via de impostos, porque não haveria qualquer manifestação de capacidade contributiva, pressuposto inafastável da incidência de todo e qualquer imposto.

Todo mundo sabe, ninguém desconhece. Atividades graciosas, gratuitas, não podem ser objeto de tributação, por via de imposto. Não há conteúdo econômico nessas atividades; logo, não podem ser alvo de imposto. E, nem mesmo de contribuições porque estas envolvem caracteres de impostos. ${ }^{305}$

\footnotetext{
${ }^{303}$ LIMA, Maria Ednalda de. Os Dois Problemas da Imunidade das Contribuições Sociais Securitárias In Revista Dialética de Direito Tributário. São Paulo: Dialética, vol. 191, agosto de 2011, p. 39-50 (p. 43 ).

${ }^{304}$ Também possuem igual entendimento Misabel Abreu Machado Derzi e Clélio Chiesa. Para a primeira, “[...] E isso por fundamentos lógicos e de fundo: a instituição pro Bono que exerce suas atividades, exclusivamente por meio de doações de terceiros, ou ainda por meio de subvenções públicas, não necessita do manto imunitório. Se a imunidade existisse apenas para tais entidades beneficentes, sustentadas pelo Estado ou pela caridade, ela perderia sua razão de ser." (BALEEIRO, Aliomar; DERZI, Misabel Abreu Machado. Limitações constitucionais ao poder de tributar. ed. atual. Rio de Janeiro: Forense, 2010. p. 557.); já para o segundo, "É inconcebível pretender restringir o alcance da imunidade em questão às entidades que prestam de forma gratuita seus serviços, pois isso representaria o esvaziamento da referida hipótese de imunidade. Exegese de tal ordem frustraria o desiderato pretendido pelo constituinte com a instituição da mencionada imunidade, consistente em estimular que outras pessoas prestem serviços de assistência social visando a auxiliar o Estado a cumprir o seu fim institucional de assistir os hipossuficientes."

${ }^{305}$ BARRETO; BARRETO, op. cit., p. 110.
} 
Dessa forma, por somente sobreviver de doações, sem que haja a cobrança de preço pela prestação de seus serviços, as regras imunitórias não se aplicam às entidades ditas filantrópicas, justamente por lhes falecer capacidade contributiva.

Regina Helena Costa, contudo, pensa de forma diferente. Para essa doutrinadora, em razão de os conceitos de entidade filantrópica e de entidade beneficente de assistência social se equivalerem, ambas possuem direito à fruição da imunidade às contribuições sociais destinadas à seguridade social:

Pois bem. As entidades beneficentes de assistência social, assim como as entidades filantrópicas, gozam de imunidade em relação às contribuições para a seguridade social, previstas no art. 195, caput e inciso I, do texto constitucional e que correspondem àquelas a cargo do empregador, da empresa e da entidade a ela equiparada na forma da lei, que recaem sobre a folha de salários e demais rendimentos do trabalho pagos ou creditados, a receita ou o faturamento e o lucro. ${ }^{306}$

Não entendemos dessa forma. Na nossa opinião, os conceitos de "instituição de assistência social", "entidade beneficente de assistência social" e de "entidades filantrópicas" são distintos e a cada uma dessas espécies de pessoa jurídica de direito privado se aplica uma regra diferente.

As instituições de assistência social somente fazem jus à imunidade dos impostos, tal qual fartamente aduzido acima; as entidades beneficentes de assistência social, por prestarem parcela de seus serviços de forma gratuita, gozam, além da imunidade dos impostos, da imunidade tributária às contribuições sociais destinadas à seguridade social; e às entidades filantrópicas, por não cobrarem nada por seus préstimos, não se aplicam as regras de imunidade, por total ausência de conteúdo econômico nessas atividades.

Portanto, diferentemente do que entende Regina Helena Costa, somos da opinião de que as regras imunitórias são inócuas em relação às entidades filantrópicas, pois, por não cobrarem pelos serviços prestados, nem mesmo daqueles que possuem condições de remunerá-los, suas atividades falecem de conteúdo econômico, razão pela qual não lhe são aplicadas as regras que tratam da imunidade tributária.

${ }^{306}$ COSTA, op. cit., p. 225. 


\section{CAPÍTULO V - IMUNIDADE TRIBUTÁRIA AOS IMPOSTOS DAS ENTIDADES BENEFICENTES DE ASSISTÊNCIA SOCIAL}

\subsection{Imunidade Tributária aos Impostos das Entidades Beneficentes de}

\section{Assistência Social}

Feitas todas as digressões acima, trataremos, nos próximos tópicos, sobre a questão da imunidade tributária dos impostos a que o artigo 150, inciso VI, alínea "c" da Constituição Federal faz referência:

Art. 150. Sem prejuízo de outras garantias asseguradas ao contribuinte, é vedado à União, aos Estados, ao Distrito Federal e aos Municípios:

$[\ldots]$

VI - instituir impostos sobre:

[...]

c) patrimônio, renda ou serviços dos partidos políticos, inclusive suas fundações, das entidades sindicais dos trabalhadores, das instituições de educação e de assistência social, sem fins lucrativos, atendidos os requisitos da lei; [...].

De acordo com o artigo supratranscrito, terão direito à fruição da imunidade tributária aos impostos incidentes sobre patrimônio, renda ou serviços as instituições de assistência social. Para que tais entidades usufruam dessa benesse contida na Constituição Federal, elas não poderão possuir fins lucrativos e deverão prestar serviços de relevante interesse público a quem deles necessitar.

Tais serviços não possuem como objetivo somente aqueles descritos no artigo 203, da Constituição Federal de 1988. A "lista" de entidades imunes aos impostos é bem mais abrangente, de modo que, basta prestar serviço de importante interesse público, auxiliando, na condição de longa manus, o Estado em seu desiderato social para que elas possam beneficiarse dessa espécie de desoneração fiscal.

Não obstante a Constituição Federal de 1988 mencionar que a imunidade dos impostos abrange somente os impostos sobre o patrimônio, renda ou serviços das instituições de assistência social, entendemos que essa hipótese imunitória deve ser interpretada de forma mais ampla, de modo a acondicionar não só os impostos sobre essas grandezas mas sim todos os (impostos) incidentes sobre as situações ou coisas relacionadas a suas finalidades essenciais. 
Por conseguinte, independentemente de o imposto incidir sobre patrimônio, renda ou serviços, se ele visar a onerar situação ou coisa ligada às finalidades essenciais das instituições de assistência social, o manto imunitório deverá ser estendido sobre tal situação ou coisa, a fim de que sobre elas não haja a incidência tributária.

Outra questão também importante acerca da imunidade tributária aos impostos das entidades de assistência social diz respeito ao veículo normativo apto a estabelecer os requisitos de sua fruição. Isso porque, tendo em vista que a imunidade do artigo 150, inciso VI, alínea “c” possui a natureza de condicionada, para a sua fruição, há a obrigatoriedade de observância de determinados e específicos pressupostos. E tais requisitos, tal qual será demonstrado, só podem ser veiculados por intermédio de lei complementar, único instrumento apto a ditar os requisitos a serem cumpridos.

Em razão de a única lei complementar atualmente em vigor que estabelece esses critérios ser o Código Tributário Nacional, o qual foi recepcionado pela Constituição Federal de 1988 como lei complementar, as instituições de assistência social deverão observar os requisitos dispostos nessa norma jurídica para que possam fazer jus a esse benefício.

Todos esses pontos serão tratados de forma minuciosa nas próximas linhas.

\subsubsection{Amplitude da expressão "patrimônio, rendas e serviços relacionadas com as}

\section{“finalidades essenciais" das entidades beneficentes de assistência social}

A Constituição Federal de 1988 prescreve em seu artigo 150, inciso VI, alíneas "b” e "c" que falece competência à União, aos Estados, ao Distrito Federal e aos Municípios para instituir impostos sobre "templos de qualquer culto" e sobre o "patrimônio, rendas ou serviços dos partidos políticos, inclusive suas fundações, das entidades sindicais dos trabalhadores, das instituições de educação e de assistência social, sem fins lucrativos”.

Mais adiante, mais precisamente em seu $\S 4^{\circ}$, o mesmo texto constitucional aduz que as vedações contidas nas alíneas "b" e "c", do artigo 150, inciso VI, correspondem somente ao patrimônio, a renda e aos serviços relacionados às finalidades essenciais das entidades abarcadas por tal preceito ${ }^{307}$ :

\footnotetext{
307 Tal regra constituiu uma inovação em relação à Constituição de 1969 , uma vez que o artigo 19 , § $1^{\circ}$ dessa Carta Magna estabeleceu essa restrição somente em relação às autarquias: “Art. 19. É vedado à União, aos Estados, ao Distrito Federal e aos Municípios: [...] III - instituir impôsto sôbre: a) o patrimônio, a renda ou os serviços uns dos outros; [...] $\S 1^{\circ} \mathrm{O}$ disposto na alínea a do item III é extensivo às autarquias, no que se refere ao patrimônio, à renda e aos serviços vinculados às suas finalidades essenciais ou delas decorrentes; mas não se
} 
Art. 150. [...]

VI - instituir impostos sobre:

b) templos de qualquer culto;

c) patrimônio, rendas ou serviços dos partidos políticos, inclusive suas fundações, das entidades sindicais dos trabalhadores, das instituições de educação e de assistência social, sem fins lucrativos.

$[\ldots]$

$\S 4^{\circ}$ - As vedações expressas no inciso VI, alíneas "b" e "c", compreendem somente o patrimônio, a renda e os serviços, relacionados com as finalidades essenciais das entidades nelas mencionadas.

Em virtude de o presente trabalho acadêmico analisar a imunidade tributária aplicável às entidades beneficentes de assistência social, o exame da limitação contida no $\S 4^{\circ}$, do artigo 150, inciso VI será feito somente à luz dessa espécie de pessoa jurídica de direito privado.

Por meio da interpretação literal do $\S 4^{\circ}$, do artigo 150 , inciso VI da Constituição Federal de 1988, pode-se concluir que, de fato, somente os impostos incidentes sobre o patrimônio, a renda ou o serviço estariam protegidos pelo manto constitucional da imunidade tributária.

Entretanto, este não é o entendimento de grande parte da doutrina ${ }^{308}$, bem como da jurisprudência pátrias. Para ambas, estarão albergados pela imunidade tributária todos os impostos supostamente exigíveis das entidades beneficentes de assistência social, desde que o bem ou a situação sobre os quais o tributo recaia estejam ligados aos objetivos sociais da entidade.

Marco Aurélio Greco, em texto intitulado "Imunidade Tributária", assevera que, enquanto o artigo 14, do Código Tributário Nacional, estabelece "para onde os recursos e disponibilidades da entidade devem ir", a regra contida no $\S 4^{\circ}$, do artigo 150 , inciso VI da Constituição Federal de 1988, atenta-se com “de onde as rendas vêm”.

Dessa forma, menciona dito autor que, para fins de aplicação do $\S 4^{\circ}$, do artigo 150, inciso VI, da Carta Magna de 1988, é irrelevante perquirir acerca de sua destinação, de modo que a relevância está em saber se eles foram "gerados por atividades ligadas às suas finalidades essenciais":

estende aos serviços públicos concedidos, nem exonera o promitente comprador da obrigação de pagar impôsto que incidir sôbre imóvel objeto de promessa de compra e venda".

${ }^{308}$ Não obstante grande parte da doutrina entender que o $\S 4^{\circ}$, do artigo 150, inciso VI da Constituição Federal de 1988 deve ser interpretado de forma abrangente, alguns importantes doutrinadores defenderam o seu caráter restritivo, de modo que seriam imunes somente os impostos sobre "o patrimônio, a renda e os serviços relacionados com as finalidades essenciais das entidades nelas mencionadas". A título exemplificativo, cita-se o posicionamento de Pontes de Miranda nesse sentido. 
Neste ponto, é igualmente importante sublinhar a profunda diferença de perspectiva que há entre a CF e o CTN.

$\mathrm{O}$ art. 14 do CTN contém regras dizendo para onde os recursos e disponibilidades da entidade devem ir.

$\mathrm{O} \S 4^{\circ}$ do art. 150 da $\mathrm{CF} / 88$ se preocupa de onde as rendas vêm.

Assim, para fins de aplicação do dispositivo constitucional, não importa a sua aplicação (no País, na finalidade essencial etc.), mas, sim, é preciso identificar se eles foram gerados por atividades ligadas às suas finalidades essenciais.

Se uma renda veio de uma atividade não relacionada com as finalidades essenciais da entidade, não haverá imunidade, ainda que venha a ser aplicada segundo as exigências do CTN. ${ }^{309}$

Ousamos discordar deste renomado doutrinador. Isso porque, diferentemente do alegado acima, a fim de se verificar a amplitude da aplicação da figura da imunidade tributária, faz-se mister analisar o destino da receita recebida e não sua origem.

Tal qual decidido pelos Tribunais pátrios, com destaque ao Supremo Tribunal Federal, desde que a renda percebida seja aplicada nos objetivos sociais da entidade beneficente, tal parcela não deverá ser oferecida à tributação, de modo que este é o único requisito exigido para constar a extensão ou não da regra contida no $\S 4^{\circ}$ do artigo 150 da Constituição Federal de 1988.

Corroborando com o posicionamento exposto acima $^{310}$, traz-se à lume as considerações de Aires Fernandino Barreto e Paulo Ayres Barreto, os quais fincaram o entendimento de que será o destino da renda percebida pela entidade imune que determinará a sua tributação ou não e não sua origem:

É amplo, pois, o sentido da cláusula "rendas relacionadas com as atividades essenciais". Desde que lícitas, pouco importa de onde provenham as rendas das instituições. Não é a fonte emanadora das rendas que está em questão. O que o texto constitucional exige é a aplicação nos objetivos institucionais. A

\footnotetext{
${ }^{309}$ GRECO, Marco Aurélio. Imunidades Tributárias. In: MARTINS, Ives Gandra da Silva (coord.). Imunidades Tributárias. São Paulo: Revista dos Tribunais, 1998. p. 718.

${ }^{310}$ Este também é o entendimento de Regina Helena Costa, para quem “pensamos que o que a Lei Maior exige é uma correspondência entre a renda obtida pelo templo e sua aplicação; então, havendo relação entre a renda e as finalidades essenciais, satisfeita estará a vontade constitucional. Logo, é a destinação dos recursos obtidos pela entidade o fator determinante do alcance da exoneração constitucional. [...] Cremos que somente mediante a análise da destinação dos recursos obtidos pelo templo, no desempenho de determinada atividade, é que se poderá respeitar a teleologia da norma imunizante, que outra não é senão assegurar a liberdade de crença e o livre exercício de cultos religiosos" (COSTA, Regina Helena. Imunidades Tributárias - teoria e análise da jurisprudência do STF. 2. ed. São Paulo: Malheiros, 2006. p. 160.
} 
cláusula volta-se, destarte, para os fins em que aplicadas as rendas e não para suas origens. ${ }^{311}$

Ruy Barbosa Nogueira, ao elaborar Parecer Jurídico endereçado à Sociedade Torre de Vigia de Bíblias e Tratados, também se manifestou no sentido de que a expressão "patrimônio, rendas e serviços relacionadas com as finalidades essenciais" está atrelada aos fins previstos no estatuto social das entidades imunes, de modo que o essencial para a manutenção da condição de entidade imune é a destinação das rendas percebidas:

II - Sem sombra de dúvida, juridicamente, a expressão "finalidades essenciais" dentro desse contexto é sinônima de "fins previstos no estatuto". Os estatutos que são os atos constitutivos de tais entidades e que contêm as proposições jurídicas que, obedecendo a todos os comandos e requisitos do direito objetivo ou da ordem jurídica vigente no País, são as necessárias e suficientes para as qualificar, "verbi gratia" como no caso consultado, dentre as "instituições de educação e de assistência social, sem fins lucrativos, atendidos os requisitos da lei".

Assim sendo, o estatuto em harmonia com a respectiva legislação é a "lei" orgânica da entidade. ${ }^{312}$

O Supremo Tribunal Federal já teve a oportunidade de manifestar-se acerca da extensão e da aplicação da expressão "patrimônio, rendas e serviços relacionadas com as finalidades essenciais", o que, inclusive, redundou na elaboração da Súmula no $724^{313}$.

Não obstante a clareza da Súmula acima reproduzida, é oportuno trazer à colação as decisões que ensejaram a edição do referido enunciado, as quais expõem o entendimento quanto à extensão da imunidade a todo o patrimônio, renda ou serviços cujas receitas sejam destinadas ao objetivo social da instituição:

Recurso extraordinário. SENAC. Instituição de educação sem finalidade lucrativa. ITBI. Imunidade. - Falta de prequestionamento da questão relativa ao princípio constitucional da isonomia. - Esta Corte, por seu Plenário, ao julgar o RE 237.718, firmou o entendimento de que a imunidade tributária do patrimônio das instituições de assistência social (artigo 150, VI, "c", da Constituição) se aplica para afastar a incidência do IPTU sobre imóveis de propriedade dessas instituições, ainda quando alugados a terceiros, desde que

\footnotetext{
${ }^{311}$ BARRETO, Aires Fernandino; BARRETO, Paulo Ayres. Imunidades Tributárias: limitações constitucionais ao poder de tributar. 2. ed. São Paulo: Dialética. p. 40.

312 NOGUEIRA, Ruy Barbosa. Imunidades contra impostos na Constituição anterior e sua disciplina mais completa na Constituição de 1988. 2. ed. São Paulo: Saraiva, 1992. p. 78.

313 "Ainda quando alugado a terceiros, permanece imune ao IPTU o imóvel pertencente a qualquer das entidades referidas pelo art. 150, VI, 'c', da Constituição, desde que o valor dos aluguéis seja aplicado nas atividades essenciais de tais entidades".
} 
os aluguéis sejam aplicados em suas finalidades institucionais. - Por identidade de razão, a mesma fundamentação em que se baseou esse precedente se aplica a instituições de educação, como a presente, sem fins lucrativos, para ver reconhecida, em seu favor, a imunidade relativamente ao ITBI referente à aquisição por ela de imóvel locado a terceiro, destinando-se os aluguéis a ser aplicados em suas finalidades institucionais. Recurso extraordinário não conhecido. ${ }^{314}$

Imunidade tributária do patrimônio das instituições de educação, sem fins lucrativos (fundação autárquica mantenedora de universidade federal) $(\mathrm{CF}$, art. 150, VI, c): sua aplicabilidade de modo a preexcluir a incidência do IPTU sobre imóvel de propriedade da entidade imune, ainda quando alugado a terceiro, sempre que a renda dos aluguéis seja aplicada em suas finalidades institucionais $^{315}$

Verifica-se, portanto, que a extensão da imunidade não se restringe ao bem utilizado propriamente pela instituição, ou à receita de sua atividade principal, mas a todas as receitas e bens vinculados à sua atividade e cujos produtos sejam destinados à consecução do seu objeto social. Isto porque, e conforme notório, a Constituição Federal ao conceder a imunidade a essas instituições o fez por entender elevados os fins para os quais foram constituídas, de modo que não haveria razão para não se imunizar todas as receitas, desde que destinadas às suas finalidades essenciais.

Com efeito, o que se busca por meio da concessão do benefício é prover às instituições os melhores meios para a preservação de valores das mais diversas naturezas que são caros ao Estado Democrático de Direito: políticos, religiosos, educacionais, sociais e culturais.

Nesse sentido, é oportuno transcrever os ensinamentos de Luciano Amaro no que se refere ao tema:

A norma constitucional - quando se refere às "rendas relacionadas às finalidades essenciais" da entidade - atém-se, como adiantamos, à destinação das rendas da entidade, e não à natureza destas. Qualquer que seja a natureza da renda auferida, se esta tiver destino alheio à finalidade assistencial da instituição, a imunidade não opera. Do mesmo modo, independentemente da natureza da renda, sendo esta destinada ao atendimento da finalidade essencial da entidade, a imunidade deve ser reconhecia.

Seria um dislate supor que "rendas relacionadas com as finalidades essenciais" pudesse significar, restritivamente, rendas produzidas pelo objeto social da entidade. Frequentemente, o atendimento do objeto social é motivo para despesas e não fonte de recursos. Fosse aquele o sentido, qualquer fonte

\footnotetext{
${ }^{314}$ RE 235.737, STF, Rel. Min. Moreira Alves, DJU de 17/05/2002. Disponível em <www.stf.jus.br>. Acesso em: 07 out 2014 .

${ }^{315}$ RE 217.233, STF, Rel. Min. Ilmar Galvão, DJU de 06/09/2001 Disponível em <www.stf.jus.br>. Acesso em: 07 out 2014.
} 
de custeio da entidade que não derivasse dos próprios usuários de seus serviços ficaria fora do alcance da imunidade.

Assim sendo, uma entidade cuja finalidade essencial seja a assistência social é imune ao imposto de renda, em relação às rendas de qualquer natureza pro ela auferida, desde que destinadas àquela finalidade. ${ }^{316}$

Tal qual aludido em outras oportunidades ao longo do presente estudo, as hipóteses imunizantes contidas no artigo 150, inciso VI, foram concebidas para preservar valores considerados como de superior interesse nacional, tais como a manutenção das entidades federadas $^{317}$, o exercício das atividades religiosas $^{318}$, da democracia, das instituições educacionais, assistenciais ${ }^{319}$ e o acesso à informação e à cultura ${ }^{320}$.

Sendo assim, a imunidade abrange não só os impostos classificados pelo Código Tributário Nacional como "impostos sobre o patrimônio, a renda ou os serviços" (ITR Imposto Territorial Rural; IPTU - Imposto Predial Territorial Urbano; ITBI - Imposto sobre Transmissão de bens imóveis e de direitos a eles relativos; IR - Imposto sobre a Renda; e ISS - Imposto Sobre Serviços), mas também, aos demais que, apesar de serem classificados como impostos sobre a produção e a circulação (IPI - Imposto sobre Produtos Industrializados; IOF - Imposto sobre Operações Financeiras; e ICMS - Imposto sobre a Circulação de Mercadorias e Serviços) repercutem no patrimônio das entidades imunes ${ }^{321}$.

\footnotetext{
316 AMARO, Luciano. Imunidades tributárias. In: MARTINS, Ives Gandra da Silva (coord.). Imunidades Tributárias. São Paulo: Revista dos Tribunais, 1998. p. 149.

${ }^{317}$ Por intermédio do artigo 150, inciso VI, "a", o qual trata da "imunidade recíproca", a CF intentou vedar, por parte dos entes políticos, a instituição de impostos sobre o patrimônio, rendas ou serviços uns dos outros. Buscou-se, por meio desse limite objetivo, preservar o pacto federativo e a autonomia das pessoas políticas.

${ }^{318} \mathrm{O}$ artigo 150, VI, "b", veda a tributação de impostos sobre o "templo de qualquer culto". O valor que se buscou com essa regra foi o da liberdade religiosa (artigo $5^{\circ}$, inciso VI) e o da livre manifestação do pensamento (artigo $5^{\circ}$, inciso IV), visando a impedir que a prática religiosa fosse obstruída via tributação.

319 O artigo 150, VI, "c", por seu turno, veda a tributação de "impostos sobre renda, patrimônio e serviços dos partidos políticos, inclusive suas fundações, das entidades sindicais dos trabalhadores, das instituições de educação e de assistência social, sem fins lucrativos, atendidos os requisitos de lei". Os valores que o Constituinte originário pretendeu abarcar nesse dispositivo foram os da liberdade de associação (artigo $5^{\circ}$, inciso XVII), de entidades associativas (artigo $5^{\circ}$, inciso XXI), de associação profissional ou sindical $\left(\operatorname{artigo} 8^{\circ}\right.$ ), de assistência aos necessitados e desassistidos (artigo $6^{\circ}$ ) e de educação (artigo $6^{\circ}$ ).

${ }^{320}$ O legislador constituinte, no artigo 150, VI, "d" e "e", proibiu a instituição de impostos sobre "livros, jornais, periódicos e o papel destinado a sua impressão", bem como sobre CDs e DVDs musicais produzidos no Brasil. O valor perseguido pelo legislador nesse dispositivo foi o da liberdade de expressão (artigo $5^{\circ}$, inciso IV) e o da manifestação de cultura e a vedação à censura (artigo $5^{\circ}$, IX). Por meio da imunidade dos livros, jornais e periódicos e dos CDs e DVDs, pretendeu-se diminuir os custos com a produção desses veículos de comunicação, de modo a facilitar o acesso da população a eles e, consequentemente, difundir a cultura.

${ }^{321}$ Atualmente, existem três Recursos Extraordinários em trâmite perante o Supremo Tribunal Federal que tratam da extensão da regra contida no artigo $150, \S 4^{\circ}$ da Constituição Federal de 1988 e que foram erigidos à condição de repercussão geral. São eles: RE 611.510, o qual possui por Relatora a Ministra Ellen Gracie. Nos autos desse RE discute-se a incidência de IOF sobre as aplicações financeiras de curto prazo efetuadas por entidades sindicais, partidos políticos, instituições de educação e de assistência social sem fins lucrativos. Houve o reconhecimento da repercussão geral pelo Pleno do STF em 21 out 2010; RE 630.790, o qual possui por Relator o Ministro Joaquim Barbosa. Nesse RE discute-se a incidência de imposto de importação sobre importações feitas por entidades religiosas. Houve o reconhecimento da repercussão geral pelo Pleno do STF em
} 
A questão relevante para o Supremo Tribunal Federal, tal qual já visto, não é a mera classificação do imposto - se incidente sobre patrimônio, renda, serviço, produção ou circulação - mas se a renda auferida será destinada aos fins estatutários da entidade. Se a resposta for afirmativa, garantida estará a condição de imune da entidade beneficente de assistência social.

Todavia, apesar de as rendas destinadas à consecução do objeto social das entidades imunes não serem objeto de tributação, haja vista a ampliação semântica da expressão "patrimônio, rendas e serviços relacionados com as finalidades essenciais" contida no texto constitucional, fato é que tal extensão não é infindável, pois ela esbarra no princípio da livre concorrência, o qual também está albergado pela Carta Magna de 1988, como visto no tópico 2.5 .

\subsubsection{Instrumento normativo hábil a estabelecer os requisitos para a fruição da} imunidade tributária aos impostos por parte das entidades beneficentes de assistência social: lei ordinária ou lei complementar?

Feitas as considerações supra, cumpre-nos, a seguir, estabelecer qual o instrumento normativo competente para dispor acerca dos requisitos a serem preenchidos pelas entidades beneficentes de assistência social, para fins de fruição da imunidade aos impostos.

O grande questionamento que circunda este assunto decorre da omissão do legislador constituinte. Isso porque, ao invés de o Constituinte originário expor que os requisitos a serem atendidos pelas entidades descritas no artigo 150, inciso VI, alínea "c" da Constituição Federal de 1988, para fins de gozo da imunidade tributária, seriam os dispostos em lei x, y ou $\mathrm{z}$, ele simplesmente mencionou que essas entidades fariam jus à imunidade tributária aos impostos desde que atendidos os "requisitos da lei". Mas que lei é esta: ordinária ou complementar?

Ab initio, já adiantamos que, no nosso entendimento, essa lei é complementar. Antes de apresentarmos a justificativa de tal assertiva, é necessário discorrer, de forma sucinta, sobre as funções da lei complementar em matéria tributária.

15 abr. 2011; e RE 600.010, o qual possui por Relator o Ministro Joaquim Barbosa. Nesse RE discute-se a incidência de Imposto de Importação e de ICMS sobre os medicamentos vendidos pela CAASP - Caixa de Assistência dos Advogados de São Paulo. Houve o reconhecimento da repercussão geral pelo Pleno do STF em 11 mar. 2010. 
Ao tempo da edição da Constituição Federal de 1967, havia um grande embate doutrinário acerca das funções da lei complementar em matéria tributária; ou seja, se ela teria função dúplice ou tríplice.

Isso porque o artigo 18, $\S 1^{\circ}$ da Constituição Federal de 1967, deixava dúvidas acerca da função da lei complementar. Nos termos desse dispositivo constitucional, "lei complementar estabelecerá normas gerais de direito tributário, disporá sobre conflitos de competência nessa matéria entre União, os Estados, o Distrito Federal e os Municípios e regulará as limitações constitucionais ao poder de tributar."

Parcela da doutrina pátria entendia que a lei complementar possuía dupla função: (i) dispor sobre conflitos de competência entre União Federal, Estados e Municípios; e (ii) regular as limitações constitucionais ao poder de tributar.

Para os seguidores dessa corrente, em decorrência da primazia da Federação e da autonomia dos Municípios, o artigo 18, § $1^{\circ}$ da Constituição Federal de 1967 deveria ser entendido sob o seguinte prisma: "Lei complementar estabelecerá normas gerais de direito tributário para dispor sobre conflitos de competência, bem como regular as limitações constitucionais ao poder de tributar". Sendo assim, à lei complementar caberia veicular normas gerais de direito tributário sobre exclusivamente conflitos de competência e limitações constitucionais ao poder de tributar.

Essa corrente doutrinária possui inúmeros seguidores, dentre os quais podemos citar Aliomar Baleeiro ${ }^{322}$, Geraldo Ataliba ${ }^{323}$, José Souto Maior Borges ${ }^{324}$, e Roque Antonio Carraza $^{325}$, dentre outros.

Contudo, para a outra corrente doutrinária, a qual adota a função tríplice da Lei Complementar, essa espécie normativa possuía a função de dispor sobre conflitos de competência entre União, Estados e Municípios; regular as limitações constitucionais ao poder de tributar; e estabelecer normas gerais em matéria tributária.

Assim, enquanto a corrente tricotômica baseava-se tão somente na interpretação literal do dispositivo constitucional, a corrente dicotômica atribuía-lhe sentido por meio da

\footnotetext{
${ }^{322}$ BALEEIRO, Aliomar; DERBI, Misabel Abreu Machado. Limitações constitucionais ao poder de tributar. ed. atual. Rio de Janeiro: Forense, 2010.

${ }^{323}$ ATALIBA, Geraldo. Normas gerais de direito financeiro e tributário e autonomia dos estados e municípios: limites à norma geral: código tributário nacional. In: Revista de Direito Público, v. 3. São Paulo: Revista dos Tribunais, 1969, p. 39.

${ }^{324}$ BORGES, José Souto Maior. Lei Complementar Tributária. São Paulo: Revista dos Tribunais, 1975.

${ }^{325}$ CARRAZA, Roque Antonio. Curso de Direito Constitucional Tributário. 29. ed. São Paulo: Malheiros, 2013, p. 918.
} 
conjugação do seu postulado aos princípios e cláusulas pétreas constitucionais, na tentativa de empreender à definição de "normas gerais" um significado mais sistemático.

Essa disputa doutrinária perdurou com mais intensidade até a promulgação da vigente Constituição Federal. Isso porque, com a promulgação da Constituição Federal de 1988, na visão do autor do presente estudo acadêmico, não restam mais dúvidas acerca da função tríplice da lei complementar em matéria tributária ${ }^{326}$.

Eis o que dispõe o artigo 146 da Constituição Federal de 1988:

Art. 146. Cabe à lei complementar:

I - dispor sobre conflitos de competência, em matéria tributária, entre a União, os Estados, o Distrito Federal e os Municípios;

II - regular as limitações constitucionais ao poder de tributar;

III - estabelecer normas gerais em matéria de legislação tributária, especialmente sobre:

a) definição de tributos e de suas espécies, bem como, em relação aos impostos discriminados nesta Constituição, a dos respectivos fatos geradores, bases de cálculo e contribuintes;

b) obrigação, lançamento, crédito, prescrição e decadência tributários;

c) adequado tratamento tributário ao ato cooperativo praticado pelas sociedades cooperativas.

d) definição de tratamento diferenciado e favorecido para as microempresas e para as empresas de pequeno porte, inclusive regimes especiais ou simplificados no caso do imposto previsto no art. 155, II, das contribuições previstas no art. 195, I e $\S \S 12$ e 13, e da contribuição a que se refere o art. 239. (Incluído pela Emenda Constitucional $n^{\circ} 42$, de 19.12.2003)

[...].

Consoante se infere da leitura do artigo 146 acima transcrito, o legislador constitucional manteve o mesmo sentido literal da Constituição Federal de 1967, conferindolhe, todavia, maior especificidade ao separar a competência de estabelecer "normas gerais em matéria de legislação tributária" em inciso apartado, bem como dispor que, nesse tocante, compete-lhe ainda definir tributos e suas espécies, fatos geradores, bases de cálculo e contribuintes, bem como as normas relativas à obrigação, crédito, prescrição e decadência tributários.

A corrente tricotômica, partindo da interpretação literal, continuou atribuindo à lei complementar as três funções acima elencadas, concedendo poderes de ingerência da União na seara de competência dos Estados e Municípios. Já a corrente dicotômica, com base

\footnotetext{
${ }^{326}$ Este também é o entendimento de Aires Fernandino Barreto e Paulo Ayres Barreto: "À luz da Constituição de 1988, parece não haver dúvida quanto à tríplice função da lei complementar, a teor do artigo 146, II." (BARRETO, Aires; BARRETO, Paulo Ayres. Imunidades tributárias: limitações constitucionais ao poder de tributar. 2. ed. São Paulo: Dialética, 2001. p. 23).
} 
novamente no princípio federativo e da autonomia dos municípios, condenou e condena sobremaneira a amplitude conferida pelo constituinte de 1988, por entender que praticamente colocou na competência da lei complementar toda matéria de natureza tributária.

Deveras, com a promulgação da Constituição Federal de 1988 grande parte da doutrina pátria adota a corrente tricotômica da Lei Complementar ${ }^{327}$, com exceção de alguns doutrinadores que mantêm o entendimento de que a Lei Complementar, em matéria tributária, possui somente duas funções: dispor sobre conflitos de competência entre União, Estados, Distrito Federal e Municípios; e regular as limitações constitucionais ao poder de tributar ${ }^{328}$.

A título exemplificativo, podemos citar Roque Antonio Carraza que, mesmo com a edição do artigo 146 da atual Carta Magna, mantém o posicionamento segundo o qual a Lei Complementar em matéria tributária possui, única e exclusivamente, as duas funções mencionadas acima:

Portanto, somos de opinião que a lei complementar em exame só poderá veicular normas gerais em matéria de legislação tributária, as quais ou disporão sobre conflitos de competência, em matéria tributária, ou regularão "as limitações constitucionais ao poder de tributar".

Reafirmamos, portanto, que só será válida a lei complementar que vier a dispor sobre conflitos de competência tributária ou a regular limitações constitucionais "ao poder de tributar". Tal conclusão, posto não deflua naturalmente da mera leitura do invocado art. 146, é a única possível se levarmos em conta, em sua exegese, dentre outros, os precitados princípios federativo, da autonomia municipal e da autonomia distrital.

A respeito, perfilhamos a denominada corrente dicotômica, liderada por Geraldo Ataliba, e cujas linhas mestras estão otimamente expostas em seu artigo "Normas gerais de direito financeiro e tributário". ${ }^{329}$

Como já mencionado, ousamos discordar de Roque Antonio Carraza, bem como daqueles doutrinadores que entendem que, mesmo com a promulgação da Constituição Federal de 1988, nosso ordenamento jurídico, em relação à função da lei complementar em matéria tributária, premia a corrente dicotômica ao invés da tricotômica.

\footnotetext{
${ }^{327}$ Frise-se que esse também o entendimento de nossos tribunais, o qual pode ser sintetizado pela análise do RE 361.829-6, de relatoria do Ministro Carlos Velloso, integrante da $2^{\text {a }}$ Turma, publicado em 13 dez. 2005.

${ }^{328}$ É importante mencionar que Paulo de Barros Carvalho não adota a corrente dicotômica nem, tampouco, a tricotômica. Para esse autor, a Lei Complementar em matéria tributária teria uma única função: veicular normas gerais de direito tributário, as quais exercem duas funções: dispor sobre conflitos de competência entre os entes políticos e regular as limitações constitucionais ao poder de tributar. Vide, nesse sentido, a obra Curso de Direito Tributário (26. ed. São Paulo: Saraiva, 2014. p. 258-259).

${ }^{329}$ CARRAZA, Roque Antonio. Curso de Direito Constitucional Tributário. 29. ed. São Paulo: Malheiros, 2013, p. 918).
} 
Isso porque, na visão do autor do presente trabalho acadêmico, está muito clara a tomada de decisão do legislador constituinte de 1988 em relação à função da lei complementar em matéria tributária. Visando a, em tese, dirimir a divergência doutrinária existente sob a égide da Constituição Federal anterior, o legislador de 1988 optou por, em cada um dos incisos do artigo 146, dispor sobre uma das funções da lei complementar em matéria tributária. Como são três incisos, são, por decorrência lógica, três as funções da lei complementar em matéria tributária: dispor sobre conflitos de competência, em matéria tributária, entre a União, os Estados, o Distrito Federal e os Municípios; regular as limitações constitucionais ao poder de tributar; e estabelecer normas gerais em matéria de legislação tributária.

A despeito da existência de divergências quanto às funções da Lei Complementar, mesmo após a promulgação da Constituição Federal de 1988, os seguidores das correntes dicotômica e tricotômica não divergem sobre um ponto: o de que compete à Lei Complementar dispor sobre limitações constitucionais ao poder de tributar.

De acordo com o texto constitucional, a figura da imunidade tributária aos impostos está inserida na "Seção II - Das limitações ao poder de Tributar", do "Capítulo I - Do Sistema Tributário Nacional", do "Título VI - Da Tributação e do Orçamento", da Constituição Federal de 1988. Portanto, a própria Carta Magna de 1988 reconhece que as imunidades tributárias aos impostos representam "limitações ao poder de tributar".

Ora, se as imunidades tributárias aos impostos, nos termos da Constituição Federal de 1988, encerram a condição de "limitações constitucionais ao poder de tributar", o único veículo introdutor competente para elencar os requisitos a serem preenchidos para fins de fruição dessas benesses é a Lei Complementar.

Nesse sentido, vejam-se as considerações de Martins acerca da necessidade de os requisitos para a fruição das imunidades condicionadas estarem dispostos, única e exclusivamente, em sede de Lei Complementar:

[...] a lei a que faz menção o constituinte é a lei complementar, como já a doutrina e a jurisprudência tinham perfilado no passado, representando o Código Tributário Nacional tal impositor de requisitos. É que, se ao legislador ordinário fosse outorgado o direito de estabelecer condições à imunidade constitucional, poderia inviabilizá-la pro domo suo. 
Por esta razão, a lei complementar, que é lei nacional e da Federação, é a única capaz de impor limitações, de resto, já plasmadas no art. 14 do Código Tributário Nacional. ${ }^{330}$

A justificativa para tanto é muito simples. Possível fosse regular a imunidade tributária aos impostos por meio de lei ordinária, cada ente político poderia fixar critérios para o usufruto desse benefício constitucionalmente garantido. Isso certamente redundaria não só em um caos legislativo, como também em uma desordem jurídica total, além de ir completamente de encontro ao intuito do legislador constituinte ao promulgar uma Carta Magna extremamente rígida como a brasileira (o intuito de limitar ao máximo possível o campo de atuação do legislador infraconstitucional $)^{331}$.

Sobre o caos jurídico que se formaria com a possibilidade de edição de lei ordinária tendente a fixar os critérios a serem atendidos pelas entidades descritas no artigo 150, inciso VI, alínea "c" da Constituição Federal de 1988, sapientes são as considerações de Aires Fernandino Barreto e Paulo Ayres Barreto:

Fosse possível estabelecer os requisitos para o gozo da imunidade, por intermédio de lei ordinária, estaríamos diante do caos. Isto porque cada ente tributante - União, Estados, Distrito Federal e Municípios - buscaria fixar as condições para o usufruto da imunidade constitucional. Cada uma dessas inúmeras leis (isto para não falar nos atos infralegais que se seguiriam) estabeleceria critérios e condicionantes os mais díspares para reger a matéria. Como não existe hierarquia entre as leis ordinárias dos diversos entes políticos, seria difícil precisar qual preceito deveria ser obedecido. Instalarse-ia, de vez, nesse campo, total desordem no ordenamento jurídico brasileiro. ${ }^{332}$

O Poder Judiciário pátrio já teve a oportunidade de estudar esse mote em diversas ocasiões, sendo que há, inclusive, posicionamento exarado pelos Ministros do Supremo Tribunal Federal a respeito da impossibilidade de lei ordinária dispor acerca dos requisitos a serem preenchidos no que concerne à imunidade tributária aos impostos a que o artigo 150, inciso VI, alínea “c” da Constituição Federal de 1988 faz alusão.

\footnotetext{
${ }^{330}$ MARTINS, Ives Gandra. Comentários à Constituição do Brasil. Tomo 1, vol. 6. São Paulo: Saraiva, 1990. p. 185.

${ }^{331}$ Por força da rigidez da Constituição Federal brasileira, Geraldo Ataliba mencionou, no texto intitulado Limitações constitucionais ao poder de tributar, que "o constituinte, que é o General, diz: legislador, faça a lei tributária. Mas deve fazer com tais e quais limitações, com tais condicionamentos, regras, limites; este legislador só pode fazer isso, aquele só pode fazer aquilo etc." (ATALIBA, op. cit., p. 113).

${ }^{332}$ BARRETO; BARRETO, op. cit., p. 25.
} 
A título exemplificativo pode-se citar a apreciação, por parte do Supremo Tribunal Federal, da Medida Cautelar na Ação Direta de Inconstitucionalidade n ${ }^{\circ} 1.802-3$ proposta pela CNS (Confederação Nacional de Saúde).

Por intermédio dessa Medida Cautelar na ADIn 1.802-3, a CNS requereu a declaração de inconstitucionalidade dos artigos 12,13 e $14^{333}$, da Lei 9.532/97, com a redação dada pelo artigo 10 da Lei 9.718/98, sob o argumento de que compete, única e exclusivamente, à Lei Complementar dispor acerca dos critérios a serem observados para fins de fruição das imunidades condicionadas.

O Supremo Tribunal Federal, ao apreciar essa Medida Cautelar, deferiu parcialmente a medida liminar pleiteada, sob o argumento de que os requisitos para a fruição da imunidade tributária aos impostos devem estar dispostos, exclusivamente, em Lei Complementar:

$[\ldots]$

II. Imunidade tributária (CF, art. 150, VI, c, e 146, II): "instituições de educação e de assistência social, sem fins lucrativos, atendidos os requisitos da lei": delimitação dos âmbitos da matéria reservada, no ponto, à

333 “Art. 12. Para efeito do disposto no art. 150, inciso VI, alínea c, da Constituição, considera-se imune a instituição de educação ou de assistência social a que preste os serviços para os quais houver sido instituída e os coloque à disposição da população em geral, em caráter complementar às atividades do estado, sem fins lucrativos.

[...]

$\S 2^{\circ}$ Para o gozo da imunidade, as instituições a que se refere este artigo estão obrigadas a atender os seguintes requisitos:

a) não remunerar, por qualquer forma, seus dirigentes pelos serviços prestados;

b) aplicar integralmente seus recursos na manutenção e desenvolvimento dos seus objetivos sociais;

c) manter escrituração completa de suas receitas e despesas em livros revestidos de formalidades que assegurem a respectiva exatidão;

d) conservar em boa ordem, pelo prazo de cinco anos, contado da data da emissão, os documentos que comprovem a origem de suas receitas e a efetivação de suas despesas, bem assim a realização de quaisquer outros atos ou operações que venham a modificar sua situação patrimonial;

e) apresentar, anualmente, declaração de rendimentos, em conformidade com o disposto em ato da Secretaria da Receita Federal;

f) recolher os tributos retidos sobre os rendimentos por elas pagos ou creditados e a contribuição para a seguridade social relativa aos empregados, bem assim cumprir as obrigações acessórias daí decorrentes;

g) assegurar a destinação de seu patrimônio a outra instituição que atenda às condições para o gozo da imunidade, no caso de incorporação, fusão, cisão ou de encerramento de suas atividades, ou a órgão público;

h) outros requisitos, estabelecidos em lei específica, relacionados com o funcionamento das entidades a que se refere este artigo.

$[\ldots]$.

Art. 13. Sem prejuízo das demais penalidades previstas na lei, a Secretaria da Receita Federal suspenderá o gozo da imunidade a que se refere o artigo anterior, relativamente aos anos-calendários em que a pessoa jurídica houver praticado ou, por qualquer forma, houver contribuído para a prática de ato que constitua infração a dispositivo da legislação tributária, especialmente no caso de informar ou declarar falsamente, omitir ou simular o recebimento de doações em bens ou em dinheiro, ou de qualquer forma cooperar para que terceiro sonegue tributos ou pratique ilícitos fiscais.

Parágrafo único. Considera-se, também, infração a dispositivo da legislação tributária o pagamento, pela instituição imune, em favor de seus associados ou dirigentes, ou, ainda, em favor de sócios, acionistas ou dirigentes de pessoa jurídica a ela associada por qualquer forma, de despesas consideradas indedutíveis na determinação da base de cálculo do imposto sobre a renda ou da contribuição social sobre o lucro líquido.

Art. 14. À suspensão do gozo da imunidade aplica-se o disposto no art. 32 da Lei no 9.430, de 1996." 
intermediação da lei complementar e da lei ordinária: análise, a partir daí, dos preceitos impugnados (L. 9.532/97, arts. 12 a 14): cautelar parcialmente deferida. 1. Conforme precedente no STF (RE 93.770, Muñoz, RTJ 102/304) e na linha da melhor doutrina, o que a Constituição remete à lei ordinária, no tocante à imunidade tributária considerada, é a fixação de normas sobre a constituição e o funcionamento da entidade educacional ou assistencial imune; não, o que diga respeito aos lindes da imunidade, que, quando susceptíveis de disciplina infraconstitucional, ficou reservado à lei complementar. 2. À luz desse critério distintivo, parece ficarem incólumes à eiva da inconstitucionalidade formal argüida os arts. 12 e $\S \S 2^{\circ}$ (salvo a alínea f) e $3^{\circ}$, assim como o parág. único do art. 13; ao contrário, é densa a plausibilidade da alegação de invalidez dos arts. 12 , § $2^{\circ}$, f; 13 , caput, e 14 e, finalmente, se afigura chapada a inconstitucionalidade não só formal mas também material do $\S 1^{\circ}$ do art. 12 , da lei questionada. 3. Reserva à decisão definitiva de controvérsias acerca do conceito da entidade de assistência social, para o fim da declaração da imunidade discutida -- como as relativas à exigência ou não da gratuidade dos serviços prestados ou à compreensão ou não das instituições beneficentes de clientelas restritas e das organizações de previdência privada: matérias que, embora não suscitadas pela requerente, dizem com a validade do art. 12, caput, da L. 9.532/97 e, por isso, devem ser consideradas na decisão definitiva, mas cuja delibação não é necessária à decisão cautelar da ação direta. ${ }^{334}$

(MC na ADIn 1.802/DF, STF, Pleno, Rel. Min. Sepúlveda Pertence, DJ de 24.10.2004).

Mais recentemente, o Ministro Joaquim Barbosa negou seguimento ao Recurso Extraordinário $\mathrm{n}^{\circ} 585.724$ interposto pela União em face de acórdão proferido pelo Tribunal Regional Federal da Quinta Região, que havia dado provimento a recurso interposto pela FAESA. Dentre outros argumentos, o Ministro Joaquim Barbosa aduziu que, preenchidos os requisitos contidos no artigo 14 do $\mathrm{CTN}$, reconhecido está o direito de a entidade não se submeter à incidência de impostos sobre seu patrimônio, renda ou propriedade, haja vista que os pressupostos para os "lindes das imunidades" aos impostos devem estar dispostos, única e exclusivamente, em Lei Complementar ${ }^{335}$.

Conforme visto acima, doutrina e jurisprudência são uníssonas ao considerar que as imunidades tributárias aos impostos devem ser regulamentadas por meio da edição de lei complementar. Atualmente, conforme será demonstrado no tópico seguinte, a única lei complementar existente no ordenamento pátrio tendente a estabelecer os pressupostos a serem preenchidos no que toca às imunidades condicionadas é o Código Tributário Nacional.

\footnotetext{
${ }_{334}$ MC na ADIn 1.802/DF, STF, Pleno, Rel. Min. Sepúlveda Pertence, DJ de 24.10.2004. Disponível em: <www.stf.jus.br>. Acesso em: 23 out 2014.

${ }^{335}$ RE 585.724, STF, Rel. Min. Joaquim Barbosa, DJ-e de 17.04.2012. Disponível em: <www.stf.jus.br〉. Acesso em: 23 out 2014.
} 


\subsection{Requisitos a serem preenchidos para fins de fruição da imunidade dos}

\section{impostos das entidades beneficentes de assistência social}

Consoante exposto, as entidades descritas no artigo 150, inciso VI, alínea "c" da Constituição Federal de 1988, para fins de fruição das imunidades tributárias, deverão preencher determinados requisitos, os quais devem constar, necessariamente, em lei complementar.

Tendo em que vista que o Código Tributário Nacional, por força do artigo $34, \S 5^{\circ}$ do $\mathrm{ADCT}^{336}$ foi recepcionado com status de lei complementar, os requisitos a serem preenchidos, para fins de gozo desse benefício instituído constitucionalmente são os constantes nesse diploma legal. E tais pressupostos estão dispostos no artigo 14, do Código Tributário Nacional $^{337-338-339}$, que assim preconiza:

Art. 14. O disposto na alínea $\mathrm{c}$ do inciso VI do art. $9^{\circ}$ é subordinado à observância dos seguintes requisitos pelas entidades nele referidas:

I - não distribuírem qualquer parcela de seu patrimônio ou de suas rendas, a qualquer título;

II - aplicarem integralmente, no País, os seus recursos na manutenção dos seus objetivos institucionais;

\footnotetext{
336 “Art. 34. O sistema tributário nacional entrará em vigor a partir do primeiro dia do quinto mês seguinte ao da promulgação da Constituição, mantido, até então, o da Constituição de 1967, com a redação dada pela Emenda $\mathrm{n}^{\mathrm{o}} 1$, de 1969 , e pelas posteriores.

[...]

$\S 5^{\circ}$ - Vigente o novo sistema tributário nacional, fica assegurada a aplicação da legislação anterior, no que não seja incompatível com ele e com a legislação referida nos $\S 3^{\circ}$ e $\S 4^{\circ}$."

${ }^{337}$ O Supremo Tribunal Federal, por diversas vezes, já se pronunciou acerca da recepção do artigo 14, do Código Tributário Nacional pela Constituição Federal de 1988. Nesse sentido: "IMUNIDADE TRIBUTÁRIA ENTIDADES VOLTADAS A ASSISTÊNCIA SOCIAL. A norma inserta na alínea 'c' do inciso VI do artigo 150 da Carta de 1988 repete o que previa a pretérita alínea 'c' do inciso III do artigo 19. Assim, foi recepcionado o preceito do artigo 14 do Código Tributário Nacional, no que cogita dos requisitos a serem atendidos para ao exercício do direito à imunidade" (MI no 420, STF, Pleno, Rel. Min. Marco Aurélio, DJ de 23.09.1994) pesquisa realizada em 04 de outubro de 2014.

338 Acerca da recepção do artigo 14, do CTN pela Constituição de 1988, vejam-se as palavras de Ives Gandra da Silva Martins: "Mantenho, pois, minha posição anterior, manifestada em escritos e conferência. Apenas lei complementar pode determinar quais os requisitos devem ser impostos ao Terceiro Setor para gozo das imunidades. Por ter sido recepcionado pelas Constituições Federais de 1967 e 1988, o artigo 14 do CTN tem esta eficácia e é aquele que impõe exaustivamente todos os requisitos necessários para gozo das imunidades. [...] No momento em que, pelo princípio da recepção, deu-se eficácia de lei complementar ao CTN (Lei 5.712), à evidência os requisitos do artigo 14 ganharam tal feição". (MARTINS, Ives Gandra da Silva. Imunidades tributárias e as Leis Complementares, Ordinárias e Federais. In Revista Direito Tributário Atual, vol. 23. São Paulo: Dialética, 2009, p. 207-213).

339 "O Código Tributário Nacional foi incorporado à ordem jurídica instaurada com a Constituição de 5 de outubro de 1988. Quanto mais não fosse, por efeito da manifestação explícita contido no § $5^{\circ}$ do art. 34 do Ato das Disposições Constitucionais Transitórias, que assegura a validade sistêmica da legislação anterior, naquilo que não for incompatível com o novo ordenamento. É o tradicional princípio da recepção, meio pelo qual se evita intensa e árdua movimentação dos órgãos legislativos para o implemento de normas jurídicas que já se encontram prontas e acabadas, irradiando sua eficácia em termos de patibilidade plena com o teor dos novos preceitos constitucionais" (CARVALHO, Paulo de Barros. Curso de Direito Tributário. 26. ed. São Paulo: Saraiva, 2014. p. 249).
} 
III - manterem escrituração de suas receitas e despesas em livros revestidos de formalidades capazes de assegurar sua exatidão.

$[\ldots]$.

Pela apreciação do trecho acima, verifica-se que as entidades, para o gozo da imunidade disposta no artigo 150, inciso VI, alínea "c" da Constituição Federal de 1988, deverão observar, cumulativamente, os seguintes requisitos: não distribuir parcela de seu patrimônio ou rendas, a qualquer título; aplicar no País todos os seus recursos na consecução de seus objetivos sociais; e manter escrituração de suas receitas e despesas nos competentes livros.

A seguir, faremos uma análise de todos os pressupostos constantes do Código Tributário Nacional tendentes a assegurar a imunidade tributária aos impostos das entidades beneficentes de assistência social.

\subsubsection{Não distribuição de parcela de seu patrimônio e renda, a qualquer título}

O primeiro requisito a ser observado pelas entidades imunes a que o artigo 150, inciso VI, alínea "c" da Constituição Federal de 1988 faz alusão é a impossibilidade de distribuição de qualquer parcela de seu patrimônio ou renda, a qualquer título.

Inicialmente, cumpre ressaltar que a obtenção de lucro (ou superávit) pela pessoa jurídica não representa violação à expressão "sem fins lucrativos" contida no artigo 150, VI, “c” da Constituição Federal de 1988, ou aos requisitos autorizados da imunidade tributária, previstos nos incisos do artigo 14 do CTN.

Tal ocorre devido a que, diferentemente de uma pessoa jurídica de direito privado que almeja o lucro como forma de ampliar seus negócios, bem como de melhor remunerar seus dirigentes, as instituições de assistência social foram criadas para, de forma desinteressada do ponto de vista econômico ou seja, não com o intuito de obter lucro e distribuí-lo a um número determinado de pessoas, mas sim no interesse da coletividade -, auxiliar o Estado no atingimento de seus objetivos, proporcionando à população uma vida digna e saudável.

Assim, não obstante as instituições de assistência social perceberem valores pela prestação de seus préstimos ou pela venda de produtos, em virtude de seu objetivo ser auxiliar o Estado no seu desiderato social e não auferir lucro e distribuí-lo aos seus dirigentes, o saldo positivo auferido (superávit) deverá ser, todo ele, vertido aos seus objetivos sociais, sob pena de suspensão da imunidade. Consequentemente, a ausência de finalidade lucrativa não impede 
a realização de superávit pela entidade, desde que ele seja utilizado para reinvestimento nela própria.

Hugo de Brito Machado, em sua obra "Comentários ao Código Tributário Nacional”, aborda muito bem essa questão:

O fim lucrativo, convém insistirmos nesse ponto, não se caracteriza pela obtenção de lucros para a própria pessoa jurídica, mas pela obtenção de lucros para os que a constituem ou integram. Uma entidade sem fins lucrativos pode lucrar, e deve lucrar, em suas atividades, como forma de fortalecer e poder cada vez melhor desempenhar sua atividade que seja do interesse da sociedade, vale dizer, de interesse público.

$[\ldots]$

O não ter fins lucrativos significa simplesmente que a instituição social ou de educação não se presta como instrumento de lucro para as pessoas que a constituem. É entidade sem fins lucrativos aquela que é constituída por pessoas que pretendem servir à sociedade de forma desinteressada. Todavia, a entidade, para exercer suas atividades e alcançar seus objetivos, precisa de recursos financeiros e por isso mesmo pode e deve obtê-los por qualquer meio lícito, inclusive cobrando pelos serviços que presta a quem por eles pode pagar. [...]. ${ }^{340}$

Portanto, a legislação não veda a simples obtenção de lucro (superávit) pela entidade, mas sim a sua distribuição aos seus integrantes. Nesse sentido, o inciso I, do artigo 14, do Código Tributário Nacional, em sua redação original, vedava a distribuição de qualquer parcela de seu patrimônio ou de suas rendas, a título de lucro ou participação no seu resultado:

Art.14. [...]

I - não distribuírem qualquer parcela de seu patrimônio ou de suas rendas, a título de lucro ou participação no seu resultado;

[...].

Com a imposição desse requisito para a concessão da imunidade tributária, o legislador objetivou impedir que os sócios e/ou dirigentes da entidade imune, os quais são as pessoas que possuem o poder de gestão e administração da sociedade, utilizem o lucro (superávit) para benefício próprio.

Dessa forma, o legislador determinou que o lucro (superávit), quando existente, fosse reinvestido na própria sociedade, em benefício da coletividade em que ela se encontra e não dos particulares que a dirigem, seja por meio da distribuição de lucros ou por intermédio da distribuição de dividendos a esses.

\footnotetext{
${ }^{340}$ MACHADO, Hugo de Brito. Comentários ao Código Tributário Nacional. Vol. 1. São Paulo: Atlas, 2003. pp. 222-223.
} 
Veja-se, nesse sentido, o posicionamento do Supremo Tribunal Federal ao conceder a medida liminar pleiteada pela CNS nos autos da MC na ADIn 1.802/DF ${ }^{341}$. Segundo os Ministros que compõem esse Tribunal Superior, não há que se falar em óbice à fruição da imunidade pelo fato de a entidade exercer atividade rentável. O que se impede é a distribuição deste superávit aos sócios, dirigentes e administradores:

I. Ação direta de inconstitucionalidade: Confederação Nacional de Saúde: qualificação reconhecida, uma vez adaptados os seus estatutos ao molde legal das confederações sindicais; pertinência temática concorrente no caso, uma vez que a categoria econômica representada pela autora abrange entidades de fins não lucrativos, pois sua característica não é a ausência de atividade econômica, mas o fato de não destinarem os seus resultados positivos à distribuição de lucros.

II. Imunidade tributária (CF, art. 150, VI, c, e 146, II): "instituições de educação e de assistência social, sem fins lucrativos, atendidos os requisitos da lei": delimitação dos âmbitos da matéria reservada, no ponto, à intermediação da lei complementar e da lei ordinária: análise, a partir daí, dos preceitos impugnados (L. 9.532/97, arts. 12 a 14): cautelar parcialmente deferida.

1. Conforme precedente no STF (RE 93.770, Muñoz, RTJ 102/304) e na linha da melhor doutrina, o que a Constituição remete à lei ordinária, no tocante à imunidade tributária considerada, é a fixação de normas sobre a constituição e o funcionamento da entidade educacional ou assistencial imune; não, o que diga respeito aos lindes da imunidade, que, quando susceptíveis de disciplina infraconstitucional, ficou reservado à lei complementar.

2. À luz desse critério distintivo, parece ficarem incólumes à eiva da inconstitucionalidade formal argüida os arts. 12 e $\S \S 2^{\circ}$ (salvo a alínea f) e $3^{\circ}$, assim como o parág. único do art. 13 ; ao contrário, é densa a plausibilidade da alegação de invalidez dos arts. 12 , § $2^{\circ}$, f; 13 , caput, e 14 e, finalmente, se afigura chapada a inconstitucionalidade não só formal mas também material do $\S 1^{\circ}$ do art. 12, da lei questionada.

3. Reserva à decisão definitiva de controvérsias acerca do conceito da entidade de assistência social, para o fim da declaração da imunidade discutida -- como as relativas à exigência ou não da gratuidade dos serviços prestados ou à compreensão ou não das instituições beneficentes de clientelas restritas e das organizações de previdência privada: matérias que, embora não suscitadas pela requerente, dizem com a validade do art. 12, caput, da L. 9.532/97 e, por isso, devem ser consideradas na decisão definitiva, mas cuja delibação não é necessária à decisão cautelar da ação direta.

O legislador infraconstitucional, visando à ampliação do rol de impeditivos à distribuição do patrimônio ou renda das entidades imunes a seus sócios e/ou dirigentes,

\footnotetext{
${ }^{341}$ MC na ADIn 1.802/DF, STF, Pleno, Rel. Min. Sepúlveda Pertence, DJ de 24.10.2004. Disponível em: <www.stf.jus.br>. Acesso em: 10 out 2014.
} 
editou, em 2001, a Lei Complementar $n^{\circ}$ 104/2001, a qual alterou a redação do artigo 14, inciso I, do Código Tributário Nacional.

Com a promulgação dessa norma jurídica, o artigo 14, inciso I, do CTN passou a ter a seguinte redação: "I - não distribuírem qualquer parcela de seu patrimônio ou de suas rendas, a qualquer título; [...]”.

Ao comentar essa alteração, Hugo de Brito Machado afirma que "essa mudança certamente teve o propósito de alcançar a distribuição feita de forma disfarçada, seja a título de remuneração por serviços prestados, seja mediante fixação de preços irreais em certas transações entre a entidade imune e aqueles que a dirigem, seja direta ou indiretamente". ${ }^{342}$ Destaca-se, inclusive, que as hipóteses de distribuição disfarçada de lucros e as consequências tributárias decorrentes estão dispostas no Decreto-Lei $\mathrm{n}^{\circ}$ 1.598/77, em seus artigos 60, 61 e $62^{343}$.

${ }^{342}$ MACHADO, op. cit., p. 225.

343 “Art. 60 - Presume-se distribuição disfarçada de lucros no negócio pelo qual a pessoa jurídica:

I - aliena, por valor notoriamente inferior ao de mercado, bem do seu ativo a pessoa ligada;

II - adquire, por valor notoriamente superior ao de mercado, bem de pessoa ligada;

III - perde, em decorrência do não exercício de direito à aquisição de bem e em benefício de pessoa ligada, sinal, depósito em garantia ou importância paga para obter opção de aquisição;

IV - a parte das variações monetárias ativas (art.18) que exceder as variações monetárias passivas (art. 18, parágrafo único). (Redação dada pelo Decreto-lei nº 2.064, de 1983)

$\mathrm{V}$ - empresta dinheiro a pessoa ligada se, na data do empréstimo, possui lucros acumulados ou reservas de lucros;

VI - paga a pessoa ligada aluguéis, royalties ou assistência técnica em montante que excede notoriamente do valor de mercado.

VII - realiza com pessoa ligada qualquer outro negócio em condições de favorecimento, assim entendidas condições mais vantajosas para a pessoa ligada do que as que prevaleçam no mercado ou em que a pessoa jurídica contrataria com terceiros; (Redação dada pelo Decreto-lei nº 2.065, de 1983)

$[\ldots]$

Art. 61. Se a pessoa ligada for sócio controlador da pessoa jurídica, presumir-se-á distribuição disfarçada de lucros ainda que os negócios de que tratam os itens I a VII do artigo 60 sejam realizados com a pessoa ligada por intermédio de outrem, ou com sociedade na qual a pessoa ligada tenha, direta ou indiretamente, interesse. (Redação dada pelo Decreto-lei no 2.065 , de 1983)

$[\ldots]$

Art. 62 - Para efeito de determinar o lucro real da pessoa jurídica:

I - nos casos dos itens I e IV do artigo 60 a diferença entre o valor de mercado e o de alienação será adicionada ao lucro líquido do exercício;

II - no caso do item Il do artigo 60, a diferença entre o custo de aquisição do bem pela pessoa jurídica e o valor de mercado não constituirá custo ou prejuízo dedutível na posterior alienação ou baixa, inclusive por depreciação, amortização ou exaustão;

III - no caso do item III do artigo 60, a importância perdida não será dedutível;

IV - no caso do item V do artigo 60 , a importância mutuada em negócio que não satisfaça às condições do $\S 1^{\circ}$ do mesmo artigo será, para efeito de correção monetária do patrimônio líquido, deduzida dos lucros acumulados ou reservas de lucros, exceto a legal. (Redação dada pelo Decreto-lei nº 2.065, de 1983)

V - no caso do item VI do artigo 60, o montante dos rendimentos que exceder do valor de mercado não será dedutível; 
Entretanto, na sequência, Hugo De Brito Machado complementa que a alteração trazida a lume pela Lei Complementar $n^{\circ}$ 104/2001 se mostrou inócua e desnecessária, na medida em que não existe outra forma de distribuição do patrimônio das sociedades que não seja a título de lucro ou participação nos resultados:

É lamentável que a pretexto de evitar fraudes que deveriam ser combatidas diretamente, o legislador tenha terminado por editar dispositivo albergando grave erro técnico, pois na verdade não há forma de distribuir patrimônio ou renda que não seja a título de lucro ou participação no resultado. A distribuição de patrimônio ou de renda que não se faça a título de lucro ou participação no resultado, feita a qualquer outro título, é fraude que pode e deve ser combatida, independentemente do dispositivo legal em questão.

Destarte, para este autor, com a alteração trazida pela Lei Complementar 104/2001, ocorreu apenas uma troca de expressões, as quais possuem, na prática, os mesmos efeitos e extensões. A vedação à distribuição disfarçada de lucros sempre esteve abarcada pelo artigo 14, I do Código Tributário Nacional, mesmo que implicitamente.

Por seu turno, para Barreto e Barreto, a redação original do inciso I, do artigo 14, do Código Tributário Nacional, apresentava-se imprópria, vez que é imanente a estas instituições a ausência de fins lucrativos. Logo, a alteração trazida pela Lei Complementar 104/2001 deu maior precisão ao artigo:

Embora não se possa afirmar que o texto primitivo não houvesse sido recepcionado pela Constituição Federal, o certo é que esse dispositivo do CTN, tal como redigido, carecia de precisão, não era tecnicamente rigoroso; sua redação era insuficiente para vedar amplamente as várias hipóteses de distribuição de superávit. A Lei Complementar 104/01, destarte, longe de afrontar a Constituição, cumpre a missão que lhe é própria, realiza adequadamente o seu intento, explicitando, rigorosamente, o espírito da letra "c" do inciso IV, do art. 150 da CF. ${ }^{344}$

VI - no caso do item VII do artigo 60, as importâncias pagas ou creditadas à pessoa ligada, que caracterizarem as condições de favorecimento, não serão dedutíveis. (Redação dada pelo Decreto-lei no 2.065, de 1983)

$\S 1^{\circ} \mathrm{O}$ lucro distribuído disfarçadamente será tributado como rendimento classificado na cédula $\mathrm{H}$ da declaração de rendimentos do administrador, sócio ou titular que contratou o negócio com a pessoa jurídica e auferiu os benefícios econômicos da distribuição, ou cujo cônjuge ou parente até o $3^{\circ}$ grau, inclusive os afins, auferiu esses benefícios. (Redação dada pelo Decreto-lei no 2.065 , de 1983)

$\S 2^{\circ} \mathrm{O}$ imposto e multa de que trata o parágrafo anterior somente poderão ser lançados de ofício após o término da ocorrência do fato gerador do imposto da pessoa jurídica ou da pessoa física beneficiária dos lucros distribuídos disfarçadamente. (Redação dada pelo Decreto-lei nº 2.065, de 1983)"

${ }^{344}$ BARRETO, Aires e BARRETO, Paulo Ayres. Imunidades Tributárias: limitações constitucionais ao poder de tributar. 2. ed. São Paulo: Dialética, 2001. p. 69. 
Assim, para esses autores, a modificação do inciso I, do artigo 14, do Código Tributário Nacional, não alterou o sentido da norma, mas apenas a adequou ao objetivo da Constituição Federal, uma vez que é impróprio falar-se em distribuição de lucros ou participação nos resultados de entidades que não visam ao lucro.

Diante dessas explanações, tem-se como clara a impossibilidade de distribuição de proventos, seja antes ou após a Lei Complementar 104/2001. Resta saber, entretanto, qual o alcance dessa proibição, se o pagamento de salários aos dirigentes e/ou administradores da entidade sem fins lucrativos constituiria "distribuição de parcela do patrimônio e rendas da entidade" passível de não aplicação da norma imunizante.

Antes de respondermos a essa questão, compete-nos declarar, a título ilustrativo que, assim como ocorre no Brasil, na Argentina as entidades sem fins lucrativos também estão impedidas de distribuir parcela de seu patrimônio aos sócios, sob pena de perda da isenção do “Impuesto de las Ganancias"345 concedida pela Lei no 20.628, de 11 de julho de 1997.

Art. 20.- Están exentos del gravamen:

[...]

f) Las ganancias que obtengan las asociaciones, fundaciones y entidades civiles de asistencia social, salud pública, caridad, beneficencia, educación e instrucción, científicas, literarias, artísticas, gremiales y las de cultura física o intelectual, siempre que tales ganancias y el patrimonio social se destinen a los fines de su creación y en ningún caso se distribuyan, directa o indirectamente, entre los socios. Se excluyen de esta exención aquellas entidades que obtienen sus recursos, en todo o en parte, de la explotación de espectáculos públicos, juegos de azar, carreras de caballos y actividades similares.

Feitas essas singelas comparações entre a legislação tributária pátria e a legislação tributária argentina, no que toca à impossibilidade de os dirigentes e/ou administradores das entidades descritas no artigo 150, inciso VI, alínea "c" da Constituição Federal de 1988 perceberem parcela do patrimônio das entidades as quais estão ligados, passaremos a responder o questionamento formulado acima: se, do ponto de vista jurídico, o pagamento de salários às pessoas acima descritas constitui “distribuição de parcela do patrimônio e rendas da entidade".

\footnotetext{
${ }^{345}$ De acordo com a legislação tributária argentina, o "impuesto de las ganancias", ou o imposto incidente sobre os rendimentos auferidos, em tradução livre, incide sobre toda e qualquer remuneração auferida pela pessoa, seja física, seja jurídica. É o que dispõe o artigo $1^{\circ}$ da Lei $n^{\circ}$ 20.628/97: “Artículo $1^{\circ}$ - Todas las ganancias obtenidas por personas de existencia visible o ideal quedan sujetas al gravamen de emergencia que establece esta ley. Los sujetos a que se refiere el páragrafo anterior residentes en el país, tributan sobre la totalidad de sus ganancias obtenidas en el país o en el exterior, pudiendo computar como pago a cuenta del impuesto de esta ley las sumas efectivamente abonadas por gravámenes análogos, sobre sus actividades en el extranjero, hasta el límite del incremento de la obligación fiscal originado por la incorporación de la ganancia obtenida en el exterior".
} 
Entendemos que o pagamento de salários a dirigentes e/ou administradores não desvirtua a condição de entidade imune da sociedade a qual tais pessoas pertencem ${ }^{346}$. Todo serviço prestado deve ser remunerado, independentemente de ser prestado para entidade com ou sem fins lucrativos, tal qual ocorre em relação às entidades de educação e de assistência social agraciadas pela imunidade tributária dos impostos. Não se faz justo que determinado dirigente e/ou administrador que dedique parcela de seu tempo às questões da entidade imune não possa ser remunerado pelos préstimos oferecidos. Assim como qualquer outro cidadão, ele possui necessidades vitais, tais como as atreladas a segurança, alimentação, educação, moradia, lazer, cultura, etc., de modo que ele não só pode como deve perceber quantias a título de remuneração pelos serviços prestados ${ }^{347}$.

Corroborando com esse entendimento, transcreve-se, abaixo, o posicionamento de Schoueri, o qual reflete o entendimento da maioria da doutrina pátria:

É muito comum que, com base no citado dispositivo do Código Tributário Nacional, defenda-se que a associação não pode remunerar seus administradores. Não parece que tal entendimento extrai-se do art. 14 acima transcrito. Com efeito, o que se veda é a distribuição de uma parcela do patrimônio ou de suas rendas, a qualquer título. Como visto, a "distribuição" pressupõe um pagamento que se desvia de suas finalidades, um ato anormal de gestão.

[...]

Daí não ser anormal que tais entidades valham-se de profissionais cuja formação permita a maximização de seus resultados. A remuneração de tais administradores, desde que baseada em critérios de mercado, não pode ser considerada um ato anormal de gestão. Ao contrário "anormal" seria esperar que profissionais tivessem dedicação exclusiva a tais entidades, sem qualquer remuneração.

Assim, não parece lícito que uma entidade sem fins lucrativos remunere seus dirigentes. Tal circunstância, por si, não será suficiente para que ela perca a imunidade. Importará, outrossim, que a remuneração não se revele excessiva, i.e, que a entidade não acabe por distribuir parcela de seu patrimônio ou por suas rendas a qualquer título, inclusive a título de remuneração de seus dirigentes. ${ }^{348}$

\footnotetext{
346 Esse também é o entendimento de Aliomar Baleeiro, que assim se manifestou "não perde o caráter de instituição de educação e assistência a que remunera apenas o trabalho de médicos, professores, enfermeiros e técnicos, ou que cobra serviços a alguns para custear assistência e educação gratuita a outros". (BALEEIRO, Aliomar; DERZI, Misabel Abreu Machado. Limitações Constitucionais ao Poder de Tributar. 8. ed. atual. Rio de Janeiro: Forense, 2010. p. 313).

${ }^{347}$ Roque Antonio Carraza é claro ao dispor, em sua obra intitulada Curso de Direito Constitucional Tributário, o pagamento de salários condizentes com a realidade do mercado não afasta a aplicação da imunidade. $\mathrm{O}$ que a afasta, na sua visão, é a remuneração exorbitante. São suas as seguintes palavras: "A remuneração dos funcionários e administradores não afasta a imunidade, desde que seja equivalente aos serviços por ele prestados. O que afasta a imunidade é a remuneração exorbitante, que mal consegue esconder a distribuição do patrimônio ou das rendas da entidade” (CARRAZA, op. cit., 2013, p. 766).

${ }^{348}$ SCHOUERI, Luís Eduardo. Direito Tributário. São Paulo: Saraiva, 2012. p. 399.
} 
Desse modo, não perderá a condição de entidade imune a que remunerar seus dirigentes e/ou, administradores. Nada obstante, é importante mencionar que tal "benesse" deve ser aplicada com parcimônia, na medida em que existe uma trava a esses pagamentos feitos a dirigentes e/ou administradores dessas entidades imunes: os valores de mercado.

Assim, para que determinada entidade, dita isenta pelo artigo 150, inciso VI, alínea “c” da Constituição Federal de 1988, possa usufruir da imunidade tributária em relação aos impostos, é preciso que as remunerações pagas a seus dirigentes e/ou administradores sejam compatíveis com as pagas pelo mercado, sob pena de descaracterização da imunidade tributária por ofensa à regra contida no artigo 14, inciso I do Código Tributário Nacional.

Corroborando esse entendimento, o autor deste trabalho científico transcreve as considerações de Aires Fernandino Barreto e Paulo Ayres Barreto:

\begin{abstract}
A remuneração do dirigente, contudo, deve equivaler aos serviços prestados, sem exorbitâncias, em níveis compatíveis com os valores de mercado, como pondera, em duas passagens, o constitucionalista Roque Carraza:

$[\ldots]$

Por todo o exposto, estamos percebendo que, se, por exemplo, uma entidade educacional efetuar remessa de lucros para o exterior, já perde o direito ao benefício constitucional. $\mathrm{O}$ mesmo podemos dizer de uma entidade assistencial que remunere seus quadros de modo excessivo, fazendo aquilo que se convencionou chamar de "distribuição disfarçada de lucros".

Como decorrência lógica, se é lícita e não descaracterizadora de imunidade a remuneração moderada de dirigentes da instituição educacional filantrópica e de assistência social, com tanto mais razão há de se concluir pela licitude de remuneração a preços de mercado pela entidade mantida de reitor, diretor e professor, por esses exatos misteres, de reitoria, direção e magistério na organização mantida. ${ }^{349}$
\end{abstract}

É importante mencionar que o Poder Judiciário brasileiro já se debruçou sobre esse assunto por diversas vezes. A fim de representar o posicionamento de nossos tribunais, traz-se à baila decisão proferida pelos integrantes do Tribunal Regional Federal da Quinta Região ${ }^{350}$, para quem os pagamentos de salário por parte das entidades imunes em montantes superiores aos pagos pelo mercado caracterizam hipótese de distribuição de parcela de patrimônio ou de renda, o que, nos termos do artigo 14, inciso I, do Código Tributário Nacional, não se coaduna com a missão e objetivo das entidades ditas imunes:

\footnotetext{
${ }^{349}$ BARRETO; BARRETO, op. Cit., p. 84.

${ }^{350}$ EDAC n ${ }^{\mathbf{o}}$ 2003.82.00.00145020-2, TRF 5 ${ }^{\mathrm{a}}$ Região, 2 ${ }^{\mathrm{a}}$ Turma, Rel. Des. Fed. Paulo Gadelha, DJ-e de 19.03.2010. Disponível em: <www.cjf.jus.br>. Acesso em: 10 out 2014.
} 
TRIBUTÁRIO E PROCESSUAL CIVIL. EMBARGOS DECLARATÓRIOS EM EMBARGOS DECLARATÓRIOS. ENTIDADE DE ENSINO SEM FINS LUCRATIVOS. UNIPÊ. CONSELHEIROS FUNDADORES DA INSTITUIÇÃO. REMUNERAÇÃO COMO DOCENTES. DESPROPORCIONAL EM RELAÇÃO AOS SALÁRIOS DOS DEMAIS PROFESSORES. CONFIGURAÇÃO DE TRANSFERÊNCIA DE LUCRO OU RENDA DA ENTIDADE. REDISCUSSÃO DA MATÉRIA. IMPOSSIBILIDADE. - As matérias tratadas nos presentes embargos declaratórios já foram devidamente analisadas no acórdão recorrido, quando asseverou a inexistência de omissão/contradição no mesmo, uma vez que o acórdão principal analisou detidamente a questão, sendo fundamentado na impossibilidade de conselheiros fundadores, bem como alguns docentes parentes destes, perceberem remunerações bem acima dos demais professores, o que configura transferência de lucros aos seus dirigentes, e, conseqüentemente descaracterizaria a imunidade tributária à entidade, não havendo, portanto, as omissões/contradições apontadas. -"O juiz não está obrigado a responder todas as alegações das partes, quando já tenha encontrado motivo suficiente para fundar a decisão, nem se obriga a ater-se aos fundamentos indicados por elas e tampouco a responder um a um a todos os argumentos". (RJTJESP 115/207 - in Código de Processo Civil e legislação processual em vigor, Theotonio Negrão, $27^{\mathrm{a}}$ ed., nota $17^{\mathrm{a}}$ ao art. 535 do CPC). - Embargos improvidos.

Dessa forma, consoante aduzido e comprovado alhures, dirigentes e/ou administradores de entidades imunes podem, normalmente, perceber salário em decorrência da prestação de serviços às entidades as quais estão ligados. O que a legislação tributária nacional coíbe é o pagamento de tais verbas em patamares superiores aos praticados pelo mercado, de modo que, afora essa hipótese, a entidade que remunerar as pessoas físicas que lhe prestam serviços não perderá a sua condição de entidade imune aos impostos.

\subsubsection{Aplicação integral, no Brasil, dos recursos na manutenção dos seus} objetivos sociais

O segundo critério a ser preenchido pelas entidades descritas no artigo 150, inciso VI, alínea "c" da Constituição Federal de 1988 diz respeito à necessidade de aplicação de suas rendas na consecução de seus objetivos sociais em solo nacional.

Como bem exemplificado por Baleeiro, em sua obra intitulada "Limitações Constitucionais ao Poder de Tributar", "não gozará da imunidade o partido organizado no Brasil para restauração da monarquia em Portugal, a congregação religiosa destinada à conversão dos chineses ao catolicismo, a associação voltada à prestação de socorros ou de 
recursos educacionais à Abissínia. Nem poderá permanecer no gozo da imunidade a confraria que remeter parte de suas rendas para a direção central em Roma ou para missões alhures. $\mathrm{O}$ fim específico há de ser produzido no Brasil." 351

Dos trechos mencionados acima, infere-se que, para a manutenção da imunidade, as instituições a que o texto constitucional faz alusão deverão reverter todas as suas rendas na consecução de seu objeto social em território brasileiro. O artigo 14, inciso II do Código Tributário Nacional é claro ao dispor que compete a essas entidades aplicar "integralmente, no País, os seus recursos na manutenção dos seus objetivos institucionais".

Realmente, o enunciado prescritivo contido no artigo 14, inciso II do Código Tributário Nacional, nada mais é do que o desdobramento da norma constitucional imunizante que incentiva a criação e manutenção de entidades privadas sem fins lucrativos que desempenhem atividades de interesse público, funcionando como longa manus do Poder Público, o qual, por mais que possua competência, no sentido de aptidão, para prover a população brasileira com saúde, educação, cultura, lazer, etc., transfere essa responsabilidade a terceiros que, em contrapartida pelos préstimos fornecidos à sociedade, deixam de recolher os impostos incidentes sobre suas rendas, patrimônio e serviços, desde que tais verbas sejam utilizadas, única e exclusivamente, na consecução de seu objeto social.

É importante mencionar que, o fato de determinada entidade imune importar equipamentos ou custear curso de integrante seu, em qualquer instituição localizada fora do território nacional, não enseja a suspensão da imunidade tributária dos impostos sobre rendas, serviços e patrimônio, sob o argumento de remessa de recursos ao exterior. Isso ocorre dado que, tais equipamentos ou know-how incorporados ao patrimônio das entidades descritas no artigo 150, inciso VI, alínea "c" da Carta Magna de 1988 estão ligados às atividades por elas desenvolvidas, de modo que não há que se falar em descumprimento da regra contida no artigo 14, inciso II do Código Tributário Nacional.

Esse também é o entendimento de Luís Eduardo Schoueri, para quem a mera aquisição de mercadoria advinda do exterior, ou o pagamento de cursos no exterior a docentes de entidades de educação não desnaturam a condição de entidade imune, na medida em que tais equipamentos e os conhecimentos adquiridos no exterior serão utilizados na consecução do objeto social das entidades imunes:

\footnotetext{
${ }^{351}$ BALEEIRO, Aliomar; DERZI, Misabel Abreu Machado. Limitações constitucionais ao poder de tributar. 8. ed. atual. Rio de Janeiro: Forense, 2010. p. 507).
} 
A exigência de aplicarem no País seus recursos deve ser compreendida com algum cuidado: teria o legislador exigido que todos os gastos daquelas entidades se dessem no País? Que dizer dos gastos com equipamentos adquiridos no exterior? Como fica a instituição de ensino que paga um curso no exterior para o aperfeiçoamento de seus docentes?

Mais adequado parece ser o entendimento de que se espera que tais entidades apliquem os recursos no interesse do País, i.e., que seus dispêndios, mesmo que ocorridos no exterior, sejam voltados a atender uma necessidade do País. ${ }^{352}$

Em outras palavras, desde que os equipamentos importados ou o know-how advindo da participação de curso no exterior tenham por objetivo aperfeiçoar e incrementar as atividades da entidade imune, tais fatos não poderão desconfigurar a imunidade tributária dos impostos

Como é sabido, as entidades ditas imunes devem, necessariamente, converter toda parcela de seu patrimônio e/ou renda à suas "finalidades essenciais", nos termos do artigo $150, \S 4^{\mathrm{o}}$, da $\mathrm{CF} / 88^{353}$. As finalidades essenciais a que alude o dispositivo constitucional acima mencionado, tal qual referido no tópico retro, confundem-se com os objetivos estatutários das entidades, consoante se infere do cotejo entre esse artigo da Carta Magna e o artigo $14, \S 2^{\circ}$ do Código Tributário Nacional ${ }^{354}$.

Dessa forma, tudo o que intentar o implemento dos objetivos estatutários estará, necessariamente, relacionado com as atividades essenciais das entidades. O patrimônio, a renda e os serviços não precisam estar diretamente destinados ao objeto social da entidade. Basta que sua utilização tenha por objetivo incrementar as atividades exercidas pela instituição, como espécie de infraestrutura empregada para viabilizar seu fim social.

Paulo de Barros Carvalho, em estudo intitulado "Imunidades Condicionadas e Suspensão das Imunidades: Análise dos requisitos do art. 14 do CTN impostos às instituições de educação sem fins lucrativos", assentou o entendimento segundo o qual todo e qualquer investimento realizado na tentativa de manter ou desenvolver as atividades das entidades descritas no artigo 150, inciso VI, alínea "c" da Carta Magna de 1988, mesmo que tal

\footnotetext{
${ }^{352}$ SCHOUERI, op. cit., p. 399.

353 “Art. 150. Sem prejuízo de outras garantias asseguradas ao contribuinte, é vedado à União, aos Estados, ao Distrito Federal e aos Municípios:

$[\ldots]$

$\S 4^{\circ}$ - As vedações expressas no inciso VI, alíneas 'b' e 'c', compreendem somente o patrimônio, a renda e os serviços, relacionados com as finalidades essenciais das entidades nelas mencionadas".

354 “Art. 14. [...] $\S 2^{\circ}$ Os serviços a que se refere a alínea c do inciso IV do artigo $9^{\circ}$ são exclusivamente, os diretamente relacionados com os objetivos institucionais das entidades de que trata este artigo, previstos nos respectivos estatutos ou atos constitutivos."
} 
investimento tenha sido realizado fora das fronteiras brasileiras, não poderá redundar na perda da imunidade tributária da instituição:

\begin{abstract}
O texto escrito, na singela conjugação de seus símbolos, não pode ser mais do que a porta de entrada para o processo interpretativo. A aplicação de recursos na manutenção dos objetivos institucionais, portanto, não se restringe à remuneração de professores, por exemplo, ou a cobrir custos diretos ocasionados pela prestação de serviços de educação. Todo investimento destinado ao aprimoramento de atividades educacionais da entidade há de ser entendido como relacionado às finalidades essenciais.

Em consequência, valores financeiros e bens de propriedade da entidade vinculados a qualquer atividade que tem por fim a educação distam de ser pretextos hábeis para lhe subtrair a condição de imune, posto que necessários ao desenvolvimento da atividade da entidade. [...]

Enfim, todo e qualquer investimento que venha, de alguma forma, a auxiliar na manutenção ou desenvolvimento dos objetivos básicos previstos no Estatuto, estará, certamente, em consonância com os requisitos dos incisos I e II, do art. 14, do Código Tributário Nacional ${ }^{355}$.
\end{abstract}

Destarte, conforme mencionado previamente, para a manutenção da condição de entidade imune do ponto de vista tributário, os entes descritos pelo artigo 150, inciso VI, alínea "c" da Constituição Federal de 1988 deverão aplicar cem por cento de suas rendas em território nacional, sob pena de perda dessa condição.

Sem embargo, a importação de produtos e/ou o pagamento de cursos em instituições localizadas no exterior, por exemplo, não possuem o condão de afastar a regra imunitória do artigo 14, inciso II do Código Tributário Nacional, desde que o produto desse investimento seja todo ele utilizado em solo pátrio, na consecução do objetivo social da entidade, em total consonância com os artigos 150, § $4^{\circ}$ da Carta Magna de 1988 e 14, § 2º do CTN.

\title{
5.2.3. Escrituração de suas receitas e despesas em livros próprios
}

Por fim, mas não menos importante, estabelece o legislador complementar que, para a fruição da imunidade, as entidades mencionadas pelo artigo 150, inciso VI, alínea "c" da Constituição Federal de 1988 deverão manter "escrituração de suas receitas e despesas em livros revestidos de formalidades capazes de assegurar sua exatidão". Trata-se de, nas

\footnotetext{
355 CARVALHO, Paulo de Barros. "Imunidades Condicionadas e Suspensão das Imunidades: Análise dos requisitos do art. 14 do CTN impostos às instituições de educação sem fins lucrativos". In: Revista de Direito Tributário n. 99. São Paulo: Malheiros, 2007. p. 16.
} 
palavras de Paulo de Barros Carvalho ${ }^{356-357}$, deveres instrumentais ou formais, conforme não possuem qualquer traço de patrimonialidade.

Embora inexista para a entidade imune o dever jurídico de recolher aos cofres públicos certa monta em dinheiro a título de tributo, subsiste a obrigação de escriturar suas receitas e despesas livros revestidos de formalidades legais. Com a prática dessas ações, pretende-se comprovar o preenchimento dos requisitos contidos nos incisos I e II do artigo 14 do Código Tributário Nacional.

Contudo, tal escrituração não necessita ser realizada de forma pormenorizada. Pode sê-lo de forma simplificada, desde que o Fisco consiga aferir o cumprimento dos requisitos dispostos nos dois primeiros incisos do artigo 14 do Código Tributário Nacional (não distribuir parcela de seu patrimônio ou rendas, a qualquer título, e aplicar, integralmente, suas rendas em atividades sociais exercidas em território nacional).

É justamente por esse motivo que Aires Fernandino Barreto e Paulo Ayres Barreto afirmam que "sem embargo, é preciso destacar a circunstância de que as instituições sem fins lucrativos não estão obrigadas à escrituração comercial, mas tão-só à chamada escrituração simplificada". 358

Logo, se a entidade imune escritura correta e regularmente suas receitas e despesas, terá cumprido integralmente o comando contido no artigo 14, inciso III do Código Tributário Nacional, de modo que eventual desvio em sua contabilidade não terá o condão de afastar o cumprimento dessa exigência, desde que tal irregularidade não impeça o Fisco de averiguar, com exatidão, o cumprimento dos requisitos dispostos nos dois primeiros dois incisos do artigo 14 desse diploma legal.

Foi nesse sentido que o Superior Tribunal de Justiça julgou o RESP no 737.719. Nessa oportunidade, os Ministros desse Tribunal Superior firmaram o entendimento de que meras irregularidades na escrituração dos livros das entidades imunes não possuem o condão de “suspender" os proveitos instituídos pela Carta Magna de 1988, uma vez que a autoridade administrativa possui meios para averiguar a correição dos procedimentos atrelados ao cumprimento dos demais pressupostos descritos no artigo 14 do Código Tributário Nacional:

\footnotetext{
${ }^{356}$ CARVALHO, Paulo de Barros. Curso de Direito Tributário. 26. ed. São Paulo: Saraiva 2014, p. 361.

${ }^{357}$ O Código Tributário Nacional, por sua vez, em seu artigo $113, \S 2^{\circ}$, conceitua os deveres instrumentais ou formais como "obrigações acessórias".

${ }^{358}$ BARRETO, Aires Fernandino; BARRETO, Paulo Aires. Imunidades Tributárias: Limitações Constitucionais ao Poder de Tributar. São Paulo: Dialética, 2001. p. 51.
} 
RECURSO ESPECIAL. IPTU. INSTITUIÇÃO DE EDUCAÇÃO E ASSISTÊNCIA SOCIAL. IMUNIDADE TRIBUTÁRIA (ART. 150, VI, C, DA CONSTITUIÇÃO FEDERAL). DESCUMPRIMENTO DA NORMA DO INCISO III DO ART. 14 DO CTN, EM VIRTUDE DA AUSÊNCIA DO REGISTRO DOS LIVROS CONTÁBEIS. CAUSA DE SUSPENSÃO DO BENEFÍCIO CONSTITUCIONAL, E NÃO DE SUA EXCLUSÃO. OFENSA AO ART. 21 DO CPC. NÃO-OCORRÊNCIA. RECURSO PARCIALMENTE PROVIDO.

1. Conforme leciona Hugo de Brito Machado, "a exigência de escrituração idônea de receitas e despesas é a exigência de um instrumento, ou meio para a aferição de que a entidade realmente atende aos demais requisitos, especialmente da ausência de fins lucrativos" ("Comentários ao Código Tributário Nacional", Volume I, São Paulo: Atlas, 2003, pág. 232).

2. Conforme consta do acórdão recorrido, a perícia técnica realizada nos autos comprovou que o recorrente está organizado sob a forma de instituição de educação e assistência social, sem fins lucrativos, bem como não foi constatada nenhuma irregularidade em seus livros contábeis no período de 31 de outubro de 1992 a 30 de maio de 1993 e de 1996 a 1999.

3. Desse modo, a ausência do registro dos livros, a qual foi regularizada durante o curso do processo, não deve ser motivo para exclusão ou cancelamento do benefício, haja vista que o descumprimento da norma do inciso III do art. 14 do CTN é mera causa de suspensão do benefício, conforme dispõe o parágrafo único do mesmo dispositivo legal.

4. Não merece acolhida a suscitada ofensa ao art. 21 do CPC. De acordo com a jurisprudência desta Corte, a parte que deu causa à instauração do processo deverá suportar o pagamento dos honorários advocatícios, com fundamento no princípio da causalidade. Na hipótese tratada nos autos, a irregularidade da escrituração contábil do recorrente deu ensejo à instauração do processo executivo e, consequentemente, da presente ação anulatória de débito fiscal, razão pela qual, deverá arcar com os ônus da sucumbência.

5. Recurso especial parcialmente provido para reconhecer o direito do recorrente à imunidade tributária durante o período mencionado". 359

Sendo assim, se a entidade imune escriturar corretamente suas despesas e receitas, com vista a comprovar a não distribuição de parcela de seu patrimônio e rendas a qualquer título, assim como a utilização de suas rendas, única e exclusivamente, em território nacional e em atenção às suas finalidades essenciais, por via de consequência restará reconhecido o cumprimento de todos os requisitos dispostos em lei complementar tendentes a garantir a aplicação da imunidade tributária dos impostos, disposta no artigo 150, inciso VI, alínea "c" da Constituição Federal de 1988.

\footnotetext{
${ }^{359}$ RESP 737.719, STJ, $1^{\text {a }}$ Turma, Rel(a). Min(a). Denise Arruda, DJ-e de 11.02.2009, pesquisa realizada em 7 de outubro de 2014. Disponível em: <www.stj.jus.br〉. Acesso em: 10 out 2014.
} 


\title{
CAPÍTULO VI - IMUNIDADE TRIBUTÁRIA ÀS CONTRIBUIÇÕES SOCIAIS DESTINADAS À SEGURIDADE SOCIAL DAS ENTIDADES BENEFICENTES DE ASSISTÊNCIA SOCIAL
}

\author{
6.1. Imunidade das Contribuições Sociais destinadas à Seguridade Social das \\ Entidades Beneficentes de Assistência Social \\ Além da imunidade tributária aos impostos, as entidades beneficentes de assistência \\ social gozam de outra hipótese imunitória: a imunidade às contribuições sociais destinadas à \\ seguridade social, desde que preenchidos os requisitos dispostos em lei. Tal regra está contida \\ no artigo $195, \S 7^{\circ}$ da Constituição Federal, que assim estabelece:
}

\footnotetext{
Art. 195. A seguridade social será financiada por toda a sociedade, de forma direta e indireta, nos termos da lei, mediante recursos provenientes dos orçamentos da União, dos Estados, do Distrito Federal e dos Municípios, e das seguintes contribuições sociais:

$[\ldots]$

$\S 7^{\circ}$ - São isentas de contribuição para a seguridade social as entidades beneficentes de assistência social que atendam às exigências estabelecidas em lei.
}

De acordo com o artigo suso transcrito, as entidades que se dedicarem à prestação de serviços de relevante interesse público a quem deles necessitar, e os oferecer de forma gratuita, fará jus à imunidade às contribuições sociais destinadas à seguridade social.

Retomando o que já foi exposto, a abrangência dos serviços a serem prestados não está adstrita tão somente aos objetivos contidos no artigo 203 da Constituição Federal de 1988, de modo que terão direito à fruição da imunidade as entidades que prestarem quaisquer serviços de relevante interesse público, desde que parcela desse préstimo ocorra de forma gratuita.

Não obstante o ponto de vista acima ser o do autor do presente trabalho científico, o qual se coaduna com o entendimento de alguns doutrinados, bem como do Supremo Tribunal Federal, há doutrinadores que não pensam dessa forma. Um desses doutrinadores, por exemplo, entende que somente farão jus à imunidade do artigo $195, \S 7^{\circ}$ as instituições beneficentes de assistência social que promoverem os objetivos descritos no artigo 203, da Constituição Federal.

Trata-se do posicionamento de Costa. Para essa doutrinadora, tal qual mencionado previamente, somente terão direito à fruição da imunidade das contribuições sociais destinadas à seguridade social as instituições que se dedicarem, única e exclusivamente, aos 
objetivos a que o artigo 203 da Constituição fazem referência: proteger a família, a maternidade, a infância e adolescência e a velhice; amparar as crianças e adolescentes carentes; promover a integração ao mercado de trabalho; habilitar e reabilitar as pessoas portadoras de deficiência e promover a sua integração à vida social; e garantir um salário mínimo mensal à pessoa portadora de deficiência assim como ao idoso que comprovarem não possuir recursos para se sustentar.

Afora essas hipóteses, ditas instituições somente poderão gozar da imunidade genérica aos impostos, nos termos do artigo 150, inciso VI, alínea "c" da Constituição Federal.

De acordo com essa doutrinadora,

\begin{abstract}
Numa primeira aproximação entre o preceito imunizante contido no art. 150 , VI, "c", e a exoneração tributária hospedada no art. $195, \S 7^{\circ}$, restrito às contribuições para a seguridade social, impõe-se observar que no primeiro estão abrangidas as instituições de educação, não alcançadas pela segunda.

$[\ldots]$

A uma porque a Constituição distingue, perfeitamente, os conceitos de assistência social (art. 203) e de educação (art. 205), não cabendo, de modo algum, sustentar-se entroncamento entre ambos para o efeito mencionado, além do fato de que as instituições que se dedicarem a essas finalidades, sem finalidade lucrativa, fazem jus à intributabilidade assegurada pelo art. 150, VI, "c".

E a duas porque, quando desejou a Lei Maior imunizar as instituições de educação, o fez, deferindo-lhes a imunidade genérica estampada no art. 150, VI, "c", todavia, não agiu do mesmo modo em relação à imunidade concernente às contribuições para a seguridade social, cuja eficácia restringiu às entidades beneficentes de assistência social. Justifica-se o tratamento díspar, em nossa opinião, pelo fato de a assistência social constituir ramo da seguridade social, o mesmo não ocorrendo com a educação. ${ }^{360}$
\end{abstract}

Apesar de concordarmos que a seguridade social não abarca a educação, conforme no Capítulo destinado a ela o legislador constituinte fez menção somente à saúde, à previdência e à assistência social, entendemos que essa figura desonerativa aplica-se, inclusive, às instituições de educação que dispõem seus serviços à parcela da população mais carente.

Como mencionado acima, a intenção do legislador constituinte, ao positivar a imunidade contida no artigo $195, \S 7^{\circ}$ da Constituição Federal de 1988 , foi a de prover os hipossuficientes com todos os recursos tendentes a auxiliá-los na mudança de sua condição de pessoa carente e desprovida de meios para a condição de autossuficiente e apta a galgar outras posições dentro dos estratos da sociedade. Um desses recursos é justamente a educação, a

${ }^{360}$ COSTA, Regina Helena. Imunidades Tributárias - Teoria e Análise da Jurisprudência do STF. 2. ed. São Paulo: 2006. p. 221-222. 
qual servirá de combustível para o hipossuficiente progredir em sua vida, seja sob o prisma profissional ou mesmo pessoal.

Portanto, apesar de entender que tal posicionamento possui extrema aderência, não só do ponto de vista jurídico, como também lógico, o que tende a seduzir o intérprete, somos do entendimento de que a regra imunitória que trata da desoneração das contribuições sociais à seguridade social, aplicável às instituições de assistência social, também se aplica às instituições de educação, as quais, por pretenderem erradicar a pobreza por meio da produção de conhecimento, também auxiliam os que o necessitam na tentativa de migração da zona de pobreza e marginalidade.

Corroborando este ponto de vista, transcreve-se abaixo o entendimento de Schoueri, para quem as entidades de educação, se prestarem serviços às pessoas mais carentes, serão agraciadas com a imunidade às contribuições sociais destinadas à seguridade social:

Note-se que a imunidade acima referida aplica-se exclusivamente às entidades de assistência social; não vale, assim, para os partidos políticos, para os sindicatos de empregadores, para as pessoas jurídicas de Direito Público, para os templos nem para as entidades de educação (a menos que as últimas, por meio de sua atividade fim, pratiquem assistência social - como o ensino a comunidades carentes). ${ }^{361}$

\subsubsection{Natureza jurídica das contribuições Sociais destinadas à seguridade social: espécie autônoma de tributo?}

Tendo em vista que nos primórdios do estudo do Direito Tributário esta disciplina era examinada juntamente com a disciplina "Ciência das Finanças", muitos doutrinadores envidaram esforços na tentativa de segregar essas duas ciências, a fim de dar uma roupagem mais jurídica ao Direito Tributário.

Essa tentativa de segregação não se deu tão somente quanto ao estudo do Direito Tributário como um todo, mas, igual e especialmente, em relação ao estudo da classificação das espécies tributárias.

Dessa maneira, a melhor doutrina do Direito Tributário buscou analisar a classificação dos tributos não mais sob o prisma científico-financeiro, porém sob o aspecto científicojurídico $^{362}$.

${ }^{361}$ SCHOUERI, Luís Eduardo. Direito tributário. 2. ed. São Paulo: Saraiva, 2012. p. 422.

${ }^{362}$ Nesse sentido, Alfredo Augusto Becker: "A maioria da doutrina do Direito Tributário já admite que a classificação dos tributos segundo o critério oferecido pela Ciência das Finanças Públicas, embora científico 
Baseando-se em critérios estritamente jurídicos, Alfredo Augusto Becker ${ }^{363}$ firmou o entendimento de que existem somente duas espécies de tributos: impostos e taxas. Para chegar a essa conclusão, esse autor baseou-se, única e exclusivamente, na configuração da base de cálculo dos tributos, haja vista que esse critério seria o verdadeiramente objetivo e jurídico.

Dessa forma, para esse autor a base de cálculo corresponde ao núcleo jurídico do tributo, de modo que será ela quem determinará a espécie tributária. Se a base de cálculo de determinado tributo estiver relacionada ao "serviço estatal ou coisa estatal" 364 , o tributo será uma taxa. Por outro lado, se a grandeza estiver relacionada a um fato lícito qualquer - não consistente em serviço estatal ou coisa estatal - estaremos diante de um imposto.

Geraldo Ataliba, por sua vez, classificou os tributos em vinculados a uma atividade estatal e não vinculados a uma atividade estatal a partir do exame do aspecto material da hipótese de incidência. De acordo com tal autor, "a materialidade do fato descrito pela h.i. (aspecto material da h.i.) de todo e qualquer tributo ou é uma atividade estatal ou outra coisa qualquer. Se for um fato qualquer, o tributo será não vinculado". ${ }^{365}$.

Já para Paulo de Barros Carvalho, para que se verifique a espécie de determinado tributo, é necessário analisar o binômio hipótese de incidência e base de cálculo. Após a realização desse cotejo, o intérprete da norma estará diante de um imposto, de uma taxa ou de uma contribuição de melhoria:

[...] Nem por isso, entretanto, a mensagem constitucional deixa de ser clara: faz-se mister analisarmos a hipótese de incidência e a base de cálculo para que possamos ingressar na intimidade estrutural da figura tributária, não bastando, para tanto, a singela verificação do fato gerador, como ingenuamente supôs o legislador do nosso Código Tributário, ao indicar, no art. $4^{\circ}$, que A natureza jurídica específica do tributo é determinada pelo fato gerador da respectiva obrigação. Por certo, tomada a sentença (CTN, art. $\left.4^{\circ}\right)$ como verdadeira, não encontraríamos método para diferençar impostos de impostos e desses as taxas, entregando-nos, imbeles, aos desacertos assíduos do político.

[...]

E foi, para este fim, qual seja, a imediata verificação da entidade, enquanto tributo, que o constituinte fez inserir a base de cálculo na compostura do tipo

financeiro, não é científico jurídico, de modo que torna-se, no plano jurídico, inservível e até prejudicial onde, como disse Gilberto de Ulhôa Canto, 'conflitos de competência impositiva são deslindados em Juízo, de modo que não convence a vencedores nem a vencidos nos pleitos em que se suscitam; incoerências e erros incompreensíveis constituem a moldura de tratamento de questões fundamentais, como a distinção entre impostos e taxas." (BECKER, Alfredo Augusto. Teoria geral do direito tributário. 5. ed. São Paulo: Noeses, 2010, p. 395.)

363 BECKER, op. cit., p. 397.

${ }^{364}$ BECKER, op. cit., p. 408.

${ }^{365}$ ATALIBA, Geraldo. Hipótese de incidência tributária. São Paulo: Malheiros, 2014. p. 131. 
tributário. $\mathrm{O}$ cotejo entre as duas realidades tributárias denunciará, logo no primeiro instante, a exigência de um imposto, de uma taxa ou de uma contribuição de melhoria, aplicando-se, subsequentemente, às várias espécies de cada qual." ${ }^{366}$

As concepções teóricas de Alfredo Augusto Becker, Geraldo Ataliba e Paulo De Barros Carvalho foram erigidas nas décadas de 60 e 70, anteriormente, portanto, à promulgação da Constituição Federal de 1988. Logo, com a edição de uma nova ordem constitucional, a doutrina dividiu-se, basicamente, em dois grandes grupos. O primeiro deles manteve a prevalência das classificações suscitadas à luz da Constituição de 1967, com as alterações decorrentes da Emenda Constitucional n 01, de 1969; e o segundo deles entendeu haver a necessidade de elaboração de nova proposta classificatória, baseada em outros critérios.

Com efeito, com a promulgação de uma nova Carta Magna, o legislador constituinte elevou a questão da destinação da receita e da restituição do tributo à condição de atributos fundamentais da estrutura dos tributos elencados na Constituição. Com isso, entendemos que a Constituição Federal de 1988 foi extremamente clara ao dispor que, no Sistema Constitucional Brasileiro, existem cinco espécies de tributos, a saber: impostos, taxas, contribuição de melhoria, empréstimo compulsório e contribuições.

Quanto a isso, deve-se dizer que, ao mencionar que as contribuições possuem destinação própria e específica e os empréstimos compulsórios são tributos restituíveis, a Constituição Federal de 1988 acabou por criar duas outras espécies tributárias, as quais, juntamente com os impostos, as taxas e as contribuições de melhoria, completam o arcabouço das espécies tributárias existentes em nosso ordenamento ${ }^{367}$. É importante frisar que a existência de cinco espécies de tributos não é uníssona entre a doutrina.

Roque Antonio Carraza ${ }^{368}$, Paulo de Barros Carvalho ${ }^{369}$ e Geraldo Ataliba ${ }^{370}$, por outro lado, são do entendimento de que existem três espécies tributárias: os impostos, as taxas e as contribuições de melhoria. Portanto, as contribuições e os empréstimos compulsórios

\footnotetext{
${ }^{366}$ CARVALHO, Paulo de Barros. Curso de Direito Tributário. 26. ed. São Paulo: Saraiva, 2014. p. 60.

${ }^{367}$ Por fim, mas não menos importante, há, também, quem entenda que existem cinco espécies de tributos: impostos, taxas, contribuição de melhoria, empréstimos compulsórios e contribuições. O Prof. Paulo Ayres Barreto, por exemplo, adota esse entendimento com o qual me filio. Essa classificação leva em conta a existência da classe de tributos vinculados e não vinculados a qual possui duas subclasses: as dos tributos com e sem destinação e os tributos restituíveis e não restituíveis.

368 CARRAZA, Roque Antonio. Curso de Direito Constitucional Tributário. 29. ed. São Paulo: Malheiros, 2013, p. 435.

${ }^{369}$ CARVALHO, Paulo de Barros. Curso de Direito Tributário. 26. ed. São Paulo: Saraiva, 2014. p. 61.

${ }^{370}$ ATALIBA, Geraldo. Hipótese de incidência tributária. São Paulo: Malheiros, 2014. p. 131.
} 
deverão se adequar a uma dessas três classes, levando em conta a análise do binômio base de cálculo e hipótese de incidência.

Contudo, grande parte da doutrina pátria entende que existem cinco espécies de tributos: impostos, taxas, contribuição de melhoria, empréstimos compulsórios e contribuições. Por todos, citam-se os ensinamentos de Paulo Ayres Barreto:

Destarte, temos as seguintes possibilidades:

1) se o tributo for vinculado, destinado e restituível, teremos um empréstimo compulsório, cuja materialidade pode ser de uma taxa ou de uma contribuição de melhoria;

2) se o tributo for vinculado, destinado e não restituível, estaremos diante de uma taxa ou de uma contribuição de melhoria, a depender do critério material eleito;

3) em face das premissas adotadas, não haveria a possibilidade lógica de um tributo ser vinculado, não destinado e restituível; o tributo vinculado tem o produto de sua arrecadação destinado a uma finalidade constitucionalmente determinada;

4) o mesmo raciocínio desenvolvido para o item anterior aplica-se à hipótese de tributo vinculado, não destinado e não restituível;

5) se o tributo for não vinculado, destinado e restituível estaremos diante de empréstimo compulsório;

6) se o tributo for não vinculado, destinado e não restituível, teremos, necessariamente, uma contribuição que não a de melhoria;

7) não há previsão, em nosso sistema tributário, de tributo não vinculado, não destinado e restituível;

8) se o tributo for não vinculado, não destinado e não restituível, estaremos diante de um imposto. ${ }^{371}$

Seguimos àqueles que entendem que o ordenamento jurídico pátrio abarca cinco espécies tributárias. Nosso posicionamento justifica-se em que, se a própria Constituição Federal de 1988 menciona que as contribuições possuem destinação própria e específica e os empréstimos compulsórios são tributos restituíveis, a Lei Maior acabou por criar duas outras espécies tributárias, as quais, juntamente com os impostos, as taxas e as contribuições de melhoria, completam o arcabouço das espécies tributárias existentes em nosso ordenamento.

Paulo Ayres Barreto ${ }^{372}$ elenca oito motivos que justificam a natureza autônoma das contribuições. São basicamente os seguintes:

1. o termo "contribuição", seja no uso comum, seja no uso técnico, possui significação própria, a qual difere sobremaneira dos vocábulos "imposto" e "taxa";

${ }^{371}$ BARRETO, Paulo Ayres. Contribuições: regime jurídico, destinação e controle. 2. ed. São Paulo: Noeses, 2011. p. 74.

372 BARRETO, op. cit., p. 95-96. 
2. o legislador constitucional de 1988 fez referência ao termo "contribuições" inúmeras vezes;

3. se o legislador constituinte referiu-se, inúmeras vezes, ao termo "contribuições", significa dizer que ele, legislador, queria deixar clara a distinção dessa espécie tributária dos impostos e das taxas;

4. a Constituição Federal de 1998 estabeleceu um regime jurídico próprio às contribuições. Se ele pretendesse que as contribuições observassem regimes próprios dos impostos ou até mesmo das taxas, ele o teria feito, assim como ocorreu com o legislador constituinte português;

5. o Texto Constitucional de 1988 estabelece diferentes mecanismos de outorga de competência tributária;

6. nos impostos, taxas e contribuições de melhoria, para fins de verificação da amplitude da competência tributária, o legislador infraconstitucional deve, de forma mandatória, voltar-se às respectivas materialidades; já em relação às contribuições, o foco está relacionado ao exame da necessidade e adequação do tributo para o custeio de uma atividade estatal específica. As materialidades, quando referidas, correspondem a um limite adicional a ser observado;

7. a arrecadação das contribuições está vinculada constitucionalmente, ao passo que a arrecadação dos impostos não possui qualquer espécie de vinculação; e

8. as receitas decorrentes das contribuições estão intimamente ligadas aos dispêndios gerados pela atividade estatal que fundamentou sua instituição; os impostos, diferentemente, não possuem qualquer espécie de controle nesse sentido.

Isto é, em razão de o legislador constituinte ter se preocupado em traçar inumeras diferenças entre as contribuições e os demais tributos existentes no Sistema Constitucional Brasileiro, a não configuração das contribuições como espécie autônoma de tributo não possui qualquer lógica ou fundamento constitucional.

Fabiana Del Padre Tomé ${ }^{373}$ também reconhece a natureza autônoma das contribuições. Para justificar seu entendimento, essa autora traça um paralelo entre essa figura tributária e os impostos e empréstimos compulsórios. Ela afirma que, ainda que as contribuições possuam materialidade semelhante a dos impostos, o critério de discrímen mais acentuado nelas diz

${ }^{373}$ TOMÉ, Ob. cit., p. 90. 
respeito ao fato de terem destinação constitucional específica, mas, diferentemente dos empréstimos compulsórios, não serem tributos restituíveis:

Uma dessas diferenças reside na destinação legal do produto arrecadado, que é vedada nos impostos e exigida nas contribuições e empréstimos compulsórios. Tendo o constituinte proibido a criação de impostos com destinação específica (art. 167, IV, do Texto Maior) e, ao contrário, prescrito esta afetação relativamente às contribuições e aos empréstimos compulsórios, não podemos ignorar o tratamento diferenciado a eles atribuído.

[...]

Havendo destinação legal da receita arrecadada, não há que se falar em imposto, mas em contribuição ou empréstimo compulsório. Estes, por sua vez, também não se confundem, haja vista a existência de um terceiro critério definiente: a restituibilidade.

[...] Logo, conclui-se que as contribuições formam uma espécie tributária autônoma, posto que apresentam conformação diversa de qualquer outra categoria de tributo.

A valer, com o advento da Constituição Federal de 1988, as contribuições passaram a integrar o capítulo dedicado ao sistema constitucional tributário e, não obstante a discussão jurisprudencial acerca da natureza jurídica das contribuições, o Supremo Tribunal Federal, ao apreciar o Recurso Extraordinário $\mathrm{n}^{\mathrm{o}} 146.733^{374}$, firmou o entendimento de que as contribuições são tributos e uma espécie autônoma deles.

A Constituição Federal de 1988 tratou das contribuições nos artigos 149 e 149-A. O artigo $149^{375}$ faz menção à existência de três espécies de contribuições: as sociais; as de

\footnotetext{
374 “Contribuição Social sobre o lucro das pessoas jurídicas. Lei 7689/88.

- Não é inconstitucional a instituição da contribuição social sobre o lucro das pessoas jurídicas, cuja natureza é tributária. Constitucionalidade dos artigos $1^{\circ}, 2^{\circ}$ e $3^{\circ}$ da Lei 7689/88. Refutação dos diferentes argumentos com que se pretende sustentar a inconstitucionalidade desses dispositivos legais.

- Ao determinar, porém, o artigo $8^{\circ}$ da Lei $7689 / 88$ que a contribuição em causa já seria devida a partir do lucro apurado no período-base a ser encerrado em 31 de dezembro de 1988, violou ele o princípio da irretroatividade contido no artigo 150, III, 'a', da Constituição Federal, que proíbe que a lei que instituiu tributo tenha, como fato gerador deste, fato ocorrido antes do início da vigência dela.

- Recurso extraordinário conhecido com base na letra 'b' do inciso III do artigo 102 da Constituição Federal, mas a que se nega provimento porque o mando de segurança foi concedido para impedir a cobrança das parcelas da contribuição social cujo fato gerador seria o lucro apurado no período-base que se encerrou em 31 de dezembro de 1988. Declaração de inconstitucionalidade do artigo $8^{\circ}$ da Lei 7689/88" (RE 146.733, STF, Pleno, Rel. Min. Moreira Alves, DJ de 06.11.1992. Disponível em: <www.stf.jus.br〉. Acesso em: 26 out 2014).

375 "Art. 149. Compete exclusivamente à União instituir contribuições sociais, de intervenção no domínio econômico e de interesse das categorias profissionais ou econômicas, como instrumento de sua atuação nas respectivas áreas, observado o disposto nos arts. 146, III, e 150, I e III, e sem prejuízo do previsto no art. 195, § $6^{\circ}$, relativamente às contribuições a que alude o dispositivo.

$\S 1^{\circ}$ Os Estados, o Distrito Federal e os Municípios instituirão contribuição, cobrada de seus servidores, para o custeio, em benefício destes, do regime previdenciário de que trata o art. 40, cuja alíquota não será inferior à da contribuição dos servidores titulares de cargos efetivos da União. (Redação dada pela Emenda Constitucional no $41,19.12 .2003)$
} 
intervenção no domínio econômico; e as de interesse das categorias profissionais ou econômicas. Há, ainda, as contribuições para o custeio do serviço de iluminação pública, dispostas no art. 149- $\mathrm{A}^{376}$, com a redação que lhe foi dada pela Emenda Constitucional $\mathrm{n}^{\circ} 39$, de 19 de dezembro de 2002.

Em razão de o presente trabalho científico voltar-se às contribuições sociais destinadas à seguridade social, nossos esforços serão canalizados para a análise dessa subespécie da espécie tributária denominada "contribuições".

As contribuições sociais destinadas à seguridade social possuem matriz constitucional no artigo 195, incisos I a IV da Constituição Federal de $1988^{377}$. Há, ainda, a possibilidade de instituição de outras fontes de custeio da seguridade social, desde que observado o disposto no artigo 154, inciso I, da Constituição Federal de 1988 (ou seja, desde que a nova contribuição seja não cumulativa, não possua base de cálculo e fato gerador dos impostos já discriminados no texto constitucional e seja editada mediante lei complementar).

Retomando um assunto já indicado, as contribuições sociais destinadas à seguridade social possuem como materialidades as contidas nos incisos I a IV do artigo 195 da

$\S 2^{\circ}$ As contribuições sociais e de intervenção no domínio econômico de que trata o caput deste artigo: (Incluído pela Emenda Constitucional $n^{\circ} 33$, de 2001)

I - não incidirão sobre as receitas decorrentes de exportação; (Incluído pela Emenda Constitucional n ${ }^{\circ} 33$, de 2001)

II - incidirão também sobre a importação de produtos estrangeiros ou serviços; (Redação dada pela Emenda Constitucional $\mathrm{n}^{\circ} 42$, de 19.12.2003)

III - poderão ter alíquotas: (Incluído pela Emenda Constitucional nº 33, de 2001)

a) ad valorem, tendo por base o faturamento, a receita bruta ou o valor da operação e, no caso de importação, o valor aduaneiro; (Incluído pela Emenda Constitucional no 33, de 2001)

b) específica, tendo por base a unidade de medida adotada. (Incluído pela Emenda Constitucional no 33 , de 2001) $\S 3^{\circ}$ A pessoa natural destinatária das operações de importação poderá ser equiparada a pessoa jurídica, na forma da lei. (Incluído pela Emenda Constitucional no 33, de 2001)

$\S 4^{\circ}$ A lei definirá as hipóteses em que as contribuições incidirão uma única vez. (Incluído pela Emenda Constitucional no 33 , de 2001)"

376 “Art. 149-A Os Municípios e o Distrito Federal poderão instituir contribuição, na forma das respectivas leis, para o custeio do serviço de iluminação pública, observado o disposto no art. 150, I e III. (Incluído pela Emenda Constitucional $\mathrm{n}^{\mathbf{0}} 39$, de 2002)

Parágrafo único. É facultada a cobrança da contribuição a que se refere o caput, na fatura de consumo de energia elétrica. (Incluído pela Emenda Constitucional no 39, de 2002)."

377 “Art. 195. A seguridade social será financiada por toda a sociedade, de forma direta e indireta, nos termos da lei, mediante recursos provenientes dos orçamentos da União, dos Estados, do Distrito Federal e dos Municípios, e das seguintes contribuições sociais:

I - do empregador, da empresa e da entidade a ela equiparada na forma da lei, incidentes sobre:

a) a folha de salários e demais rendimentos do trabalho pagos ou creditados, a qualquer título, à pessoa física que lhe preste serviço, mesmo sem vínculo empregatício;

b) a receita ou o faturamento;

c) o lucro;

II - do trabalhador e dos demais segurados da previdência social, não incidindo contribuição sobre aposentadoria e pensão concedidas pelo regime geral de previdência social de que trata o art. 201;

III - sobre a receita de concursos de prognósticos.

IV - do importador de bens ou serviços do exterior, ou de quem a lei a ele equiparar." 
Constituição Federal de 1988. Assim, sempre que ocorrer no mundo fenomênico uma das materialidades descritas no artigo 195, incisos I a IV e tal acontencimento for vertido em linguagem competente, seu produto será destinado à União para custear a seguridade social.

Por tratar-se de espécie tributária autonônoma, a instituição desse tributo deve observar não somente os princípios constitucionais aplicáveis a toda espécie tributária, mas também o princípio da anterioridade nonagesimal, nos termos do artigo $195, \S 6^{\circ}$ da Constituição Federal de $1988^{378}$.

\subsection{Imunidade ou isenção das contribuições destinadas à seguridade social das} entidades beneficentes de assistência social?

Tal restou confirmado no tópico 2.2 do presente trabalho científico, imunidade e isenção não são institutos idênticos. Pelo contrário, já que existem muito mais diferenças entre ambos do que similitudes, dado que as normas jurídicas que tratam da figura imunitória devem estar previstas, sem qualquer espécie de ressalva ou exceção, no texto constitucional.

As normas de imunidade tributária são normas de estrutura, expressamente contidas na Constituição Federal de 1988, que se prestam a auxiliar o legislador infraconstitucional na demarcação de sua competência tributária estabelecendo as situações, pessoas ou coisas sobre as quais ele não poderá estender o manto arrecadatório.

Por sua vez, a isenção, mesmo também possuindo a natureza de norma de estrutura, não atua em âmbito constitucional, mas tão somente na esfera legal, limitando de forma parcial a abrangência de um ou mais dos critérios, seja do antecedente ou do consequente, da norma jurídica tributária, impedindo, dessa forma, o nascimento do tributo.

Se as regras de imunidade tributária só podem estar contidas na Constituição Federal, é mandatório reconhecer a atecnia do termo "isenção" utilizada pelo legislador constituinte na redação do artigo $195, \S 7^{\circ}$, de modo que onde se lê "isenção", deve o exegeta interpretar “imunidade”. Tal entendimento é uníssono, há muito, na doutrina e na jurisprudência.

\footnotetext{
378 “Art. 195. A seguridade social será financiada por toda a sociedade, de forma direta e indireta, nos termos da lei, mediante recursos provenientes dos orçamentos da União, dos Estados, do Distrito Federal e dos Municípios, e das seguintes contribuições sociais: [...]

$\S 6^{\circ}$ - As contribuições sociais de que trata este artigo só poderão ser exigidas após decorridos noventa dias da data da publicação da lei que as houver instituído ou modificado, não se lhes aplicando o disposto no art. 150 , III, 'b'."
} 
No que diz respeito ao posicionamento doutrinário, fazemos menção aos entendimentos de Regina Helena Costa ${ }^{379}$, Roque Antonio Carraza ${ }^{380}$, Misabel Abreu Machado Derzi ${ }^{381}$, Luís Eduardo Schoueri ${ }^{382}$ e Paulo de Barros Carvalho ${ }^{383}$. Por todos, vejamse as expressas considerações de Aires Fernandino Barreto e Paulo Ayres Barreto:

Como as palavras utilizadas pelo legislador não observam o rigor científico, sua significação não pode ser tomada por sua singela literalidade, mas há de ser confirmada pelo sistema constitucional. Para ilustrar esse asserto basta referir, entre tantos outros exemplos de equívocos de linguagem, o exibido pelo $\S 7^{\circ}$ do artigo 195 . Ali se emprega a palavra isenção para estatuir o que, em verdade, é imunidade.

$\mathrm{O}$ poder constituinte originário, portanto, embora usando incorretamente o termo isenção (quando deveria ter utilizado a expressão imunidade, na Lei Magna, art. $195, \S 7^{\circ}$, tencionou dar condições financeiras a que as entidades assistenciais coadjuvassem o Estado na tentativa de realização do bem comum. ${ }^{384}$

A primeira vez em que o Supremo Tribunal Federal manifestou-se no que se refere à natureza jurídica de "imunidade" e não de "isenção" do comando inserto no artigo 195, § $7^{\circ}$ da Constituição Federal de 1988 se deu quando do julgamento do Mandado de Injunção no 232, impetrado pelo Centro de Cultura Prof. Luiz Freire em face do Congresso Nacional, a fim de que esse órgão determinasse aos seus integrantes a elaboração de norma regulamentadora da imunidade lá contida.

O Supremo Tribunal Federal, por maioria de votos, nessa oportunidade, reconheceu a mora do Congresso em editar tal normativo e determinou que, em seis meses da publicação de sua decisão, fossem adotadas as "providências legislativas que se impõem para o cumprimento da obrigação de legislar decorrente do artigo 195, § 7º da Constituição":

Mandado de Injunção.

- Legitimidade ativa da requerente para impetrar mandado de injunção por falta de regulamentação do disposto no $\S 7^{\circ}$ do artigo 195 da Constituição Federal.

\footnotetext{
${ }^{379}$ COSTA, Regina Helena. Imunidades tributárias - teoria e análise da jurisprudência do STF. 2. ed. São Paulo: Malheiros, 2006. p. 220.

${ }^{380}$ CARRAZA, Roque Antonio. Curso de Direito Constitucional Tributário. 29. ed. São Paulo: Malheiros, 2013. p. 969.

${ }^{381}$ BALEEIRO, Aliomar; DERZI, Misabel Abreu Machado. Limitações constitucionais ao poder de tributar. 8. ed. atual. Rio de Janeiro: Forense, 8 ed., 2010, p. 513.

382 SCHOUERI, Luís Eduardo. Direito Tributário. 2. ed. São Paulo: Saraiva, 2012. p. 422.

${ }^{383}$ CARVALHO, Paulo de Barros. Curso de Direito Tributário. 26. ed. São Paulo: Saraiva, 2014. p. 247.

${ }^{384}$ BARRETO, Aires Fernandino; BARRETO, Paulo Ayres. Imunidades tributárias: limitações constitucionais ao poder de tributar. 2. ed. São Paulo: Dialética, 2001. p. 105.
} 
- Ocorrência, no caso, em face do disposto no artigo 59 do ADCT, de mora, por parte do Congresso, na regulamentação daquele preceito constitucional.

- Mandado de Injunção conhecido, em parte, e, nessa parte, deferido para declarar-se o estado de mora em que se encontra o Congresso Nacional, a fim de que, no prazo de seis meses, adote ele as providências legislativas que se impõem para o cumprimento da obrigação de legislar decorrente do artigo $195, \S 7^{\circ}$, da Constituição, sob pena de, vencido esse prazo sem que essa obrigação se cumpra, passar o requerente a gozar da imunidade requerida" ${ }^{385}$.

E esse tem sido o entendimento do Supremo Tribunal Federal desde então, ou seja, o de que a regra contida no artigo $195, \S 7^{\circ}$ da $\mathrm{CF}$ veicula não uma isenção, mas sim uma imunidade.

Mais recentemente, o Supremo Tribunal Federal reafirmou tal entendimento. Ao julgar o Recurso Extraordinário $n^{\circ} 636.941^{386}$, alçado à condição de repercussão geral, de relatoria do Ministro Luiz Fux, no qual se discutiu a aplicação da regra de imunidade à Contribuição ao Programa de Integração Social (PIS), esse Tribunal Superior reafirmou a condição de imunidade da exoneração contida no artigo 195, § $7^{\circ}$ da Carta da República de 1988, de modo que inexiste qualquer dúvida e/ou discussão acerca da natureza jurídica do comando contido em tal dispositivo constitucional.

Dessa forma, somos categóricos, assim como o são doutrina e jurisprudência, ao afirmar que a regra contida no artigo 195, § $7^{\circ}$ da Constituição Federal de 1988 encerra verdadeira imunidade, sendo certo que terão direito à fruição dessa benesse constitucional as entidades beneficentes de assistência social que cumprirem os pressupostos dispostos em norma infraconstitucional, a qual, conforme será visto a seguir, é representada pela lei complementar.

\footnotetext{
${ }^{385}$ MI no 232, STF, Pleno, Rel. Min. Moreira Alves, DJ de 27.03.1992. Disponível em: 〈www.stf.jus.br〉. Acesso em: 25 out 2014.

386 "RECURSO EXTRAORDINÁRIO. REPERCUSSÃO GERAL. REPERCUSSÃO GERAL CONEXA. RE 566.622. IMUNIDADE AOS IMPOSTOS. ART. 150, VI, C, CF/88. IMUNIDADE ÀS CONTRIBUIÇÕES. ART. $195, \S 7^{\circ}, C F / 88$. O PIS É CONTRIBUIÇÃO PARA A SEGURIDADE SOCIAL (ART. 239 C/C ART. 195, I, CF/88). A CONCEITUAÇÃO E O REGIME JURÍDICO DA EXPRESSÃO 'INSTITUIÇÕES DE ASSISTÊNCIA SOCIAL E EDUCAÇÃO' (ART. 150, VI, C, CF/88) APLICA-SE POR ANALOGIA À EXPRESSÃO 'ENTIDADES BENEFICENTES DE ASSITÊNCIA SOCIAL' (ART. 195, § 7 , CF/88). AS LIMITAÇÕES CONSTITUCIONAIS AO PODER DE TRIBUTAR SÃO O CONJUNTO DE PRINCÍPIOS E IMUNIDADES TRIBUTÁRIAS (ART. 146, II, CF/88). A EXPRESSÃO 'ISENÇÃO' UTILIZADA NO ART. 195, § $7^{\circ}, \mathbf{C F} / 88$, TEM O CONTEÚDO DE VERDADEIRA IMUNIDADE.[...]” (RE n. 636.941, STF, Pleno, Rel. Min. Luiz Fux, DJ-e de 03.04.2014. Disponível em: <www.stf.jus.br〉. Acesso em: 25 out 2014).
} 


\subsection{Instrumento normativo competente para regular as imunidades às} contribuições sociais das entidades beneficentes de assistência social: lei ordinária ou lei complementar?

Se inexiste dúvida, seja na doutrina ou na jurisprudência ${ }^{387}$, a respeito do instrumento normativo apto a estabelecer os critérios de fruição das imunidades aos impostos das entidades descritas no artigo 150, inciso VI, alínea "c" da Constituição Federal, o mesmo não se pode dizer em relação às imunidades a que o artigo $195, \S 7^{\circ}$ da Constituição Federal se refere.

A despeito de a doutrina ser uníssona em que somente lei complementar pode dispor acerca dos requisitos a serem preenchidos pelas entidades beneficentes de assistência social para o gozo da imunidade às contribuições sociais destinadas à seguridade social, este, contudo, até o momento, não é o entendimento do Supremo Tribunal Federal, dos Tribunais inferiores e nem, tampouco, do Fisco.

De acordo com o entendimento fazendário e jurisprudencial, as normas que tratam dos requisitos para a fruição das imunidades às contribuições sociais destinadas à seguridade social podem, perfeitamente, ser reguladas via lei ordinária. Para tanto, utilizam-se os seguintes argumentos:

1. o de que a expressão "requisitos da lei" contida na parte final do artigo $195, \S$ $7^{\circ}$, da Constituição Federal, refere-se à lei ordinária e não à lei complementar,

\footnotetext{
387 “I. Ação direta de inconstitucionalidade: Confederação Nacional de Saúde: qualificação reconhecida, uma vez adaptados os seus estatutos ao molde legal das confederações sindicais; pertinência temática concorrente no caso, uma vez que a categoria econômica representada pela autora abrange entidades de fins não lucrativos, pois sua característica não é a ausência de atividade econômica, mas o fato de não destinarem os seus resultados positivos à distribuição de lucros. II. Imunidade tributária (CF, art. 150, VI, c, e 146, II): "instituições de educação e de assistência social, sem fins lucrativos, atendidos os requisitos da lei": delimitação dos âmbitos da matéria reservada, no ponto, à intermediação da lei complementar e da lei ordinária: análise, a partir daí, dos preceitos impugnados (L. 9.532/97, arts. 12 a 14): cautelar parcialmente deferida. 1. Conforme precedente no STF (RE 93.770, Muñoz, RTJ 102/304) e na linha da melhor doutrina, o que a Constituição remete à lei ordinária, no tocante à imunidade tributária considerada, é a fixação de normas sobre a constituição e o funcionamento da entidade educacional ou assistencial imune; não, o que diga respeito aos lindes da imunidade, que, quando susceptíveis de disciplina infraconstitucional, ficou reservado à lei complementar. 2. À luz desse critério distintivo, parece ficarem incólumes à eiva da inconstitucionalidade formal argüida os arts. 12 e $\S \S 2^{\circ}$ (salvo a alínea f) e $3^{\circ}$, assim como o parág. único do art. 13; ao contrário, é densa a plausibilidade da alegação de invalidez dos arts. $12, \S 2^{\circ}$, f; 13 , caput, e 14 e, finalmente, se afigura chapada a inconstitucionalidade não só formal mas também material do $\S 1^{\circ}$ do art. 12 , da lei questionada. 3. Reserva à decisão definitiva de controvérsias acerca do conceito da entidade de assistência social, para o fim da declaração da imunidade discutida - como as relativas à exigência ou não da gratuidade dos serviços prestados ou à compreensão ou não das instituições beneficentes de clientelas restritas e das organizações de previdência privada: matérias que, embora não suscitadas pela requerente, dizem com a validade do art. 12, caput, da L. 9.532/97 e, por isso, devem ser consideradas na decisão definitiva, mas cuja delibação não é necessária à decisão cautelar da ação direta." (ADI no 1802, STF, Pleno, Rel. Min. Sepúlveda Pertence, DJ de 13.02.2004. Disponível em: <www.stf.jus.br> Acesso em: 7 nov. 2014.)
} 
pois, do contrário, o legislador constituinte faria expressa menção à lei complementar; e

2. o artigo 14 do Código Tributário Nacional não se aplica às contribuições sociais destinadas à seguridade social, porque só se refere à figura dos impostos e não às demais espécies tributárias.

Entretanto, já referimos ao fato de não podermos concordar com tal posicionamento. Isso decorre de o artigo $195, \S 7^{\circ}$ da Constituição Federal, ao consagrar legítima imunidade tributária, constituir-se em verdadeira "limitação constitucional ao poder de tributar", a qual só pode ser regulada por meio de lei complementar, a teor do que dispõe o artigo 146, inciso II da Constituição Federal de 1988.

Por conta do julgamento do Mandado de Injunção $n^{\circ}$ 232-1, o Supremo Tribunal Federal teve a oportunidade de decidir a questão. No entanto, somente tangenciou o assunto ao reconhecer a necessidade de regulamentação específica da norma contida no artigo 195, § $7^{\circ}$, da Constituição Federal:

Mandado de Injunção.

- Legitimidade ativa da requerente para impetrar mandado de injunção por falta de regulamentação do disposto no $\S 7^{\circ}$ do artigo 195 da Constituição Federal.

- Ocorrência, no caso, em face do disposto no artigo 59 do ADCT, de mora, por parte do Congresso, na regulamentação daquele preceito constitucional. - Mandado de Injunção conhecido, em parte, e, nessa parte, deferido para declarar-se o estado de mora em que se encontra o Congresso Nacional, a fim de que, no prazo de seis meses, adote ele as providências legislativas que se impõem para o cumprimento da obrigação de legislar decorrente do artigo $195, \S 7^{\circ}$, da Constituição, sob pena de, vencido esse prazo sem que essa obrigação se cumpra, passar o requerente a gozar da imunidade requerida. ${ }^{388}$

O Supremo Tribunal Federal, ao reconhecer a omissão legislativa, por maioria de votos, em vez de determinar a aplicação do artigo 14 do Código Tributário Nacional - única norma jurídica de natureza complementar existente no ordenamento que estabeleça requisitos para fruição da imunidade tributária - estabeleceu que o Congresso Nacional, em um período de até seis meses, instituísse uma lei visando ao cumprimento do artigo $195, \S 7^{\circ}$, da Constituição Federal, "sob pena de, vencido esse prazo sem que essa obrigação se cumpra, passar o requerente a gozar da imunidade requerida".

${ }^{388}$ MI no 232-1, STF, Pleno, Rel. Min. Moreira Alves, DJ de 27.03.1992. Disponível em: <www.stf.jus.br>. Acesso em: 10 nov. 2014. 
Por conseguinte, de acordo com o entendimento do Supremo Tribunal Federal exarado nos autos do Mandado de Injunção $n^{\circ} 232-1$, em razão de o artigo 195, § $7^{\circ}$, da Constituição Federal de 1988 possuir eficácia limitada ${ }^{389}$, o direito à fruição da imunidade às contribuições sociais destinadas à seguridade social somente irradiaria seus efeitos após a edição da norma jurídica mencionada pela parte final do dispositivo constitucional acima transcrito. E, como a parte final desse dispositivo constitucional menciona a expressão "lei", entendeu-se que essa lei poderia ser a ordinária e não a complementar, pois, se assim não fosse, o legislador constituinte teria, expressamente, utilizado o termo "lei complementar". Contudo, não podemos coadunar com esse entendimento, uma vez que as normas constitucionais que tratam das imunidades tributárias condicionadas possuem aplicabilidade imediata e eficácia contida $^{390}$ e não limitada.

Aplicabilidade imediata porque receberam (normas imunitórias) do constituinte carga normativa suficiente para sua imediata observância, não demandando qualquer espécie de intermediação legislativa. Tanto é verdade que o artigo $5^{\circ}, \S 1^{\circ}$ da Constituição Federal de 1988 afirma que "as normas definidoras de direitos e garantias fundamentais têm aplicação imediata".

Eficácia contida porque, em relação às imunidades tributárias condicionadas, o legislador determinou o preenchimento de alguns requisitos, para fins de fruição do benefício constitucional.

Como sabido, as normas imunizantes são normas que possuem um comando negativo, proibitivo. Dessa forma, de acordo com a hermenêutica, as normas proibitivas prescindem de regulamentação. Isso quer dizer que, via de regra, as normas que versam sobre imunidades tributárias possuem eficácia plena.

Todavia, como toda regra possui exceção, na hipótese de a própria Carta da República estabelecer que determinada norma jurídica necessitará ser restringida, estar-se-á diante de uma norma constitucional de eficácia contida, já que para a sua completa e correta aplicação haverá a necessidade de cumprimento de específicos pressupostos estipulados pelo legislador infraconstitucional.

\footnotetext{
${ }^{389}$ Entende-se por norma constitucional de eficácia limitada aquela que somente produzirá efeitos a partir do momento da edição da norma integradora, de natureza infraconstitucional. As normas de eficácia limitada não possuem os elementos necessários a sua executoriedade. Dessa forma, enquanto não forem complementadas pelo legislador, elas não produzirão efeitos plenos.

${ }^{390}$ Por outro lado, norma constitucional de eficácia contida é aquela que, não obstante produza efeitos desde logo, indepentemente de regulamentação, pode, por expressa disposição constitucional, ter seu alcance restringido. Nada obstante, enquanto não materializado o fator de restrição, a norma possui eficácia plena.
} 
Corroborando esse entendimento, transcrevem-se os ensinamentos de Regina Helena Costa:

\begin{abstract}
Em algumas hipóteses de imunidades, diversamente, o legislador infraconstitucional é chamado a complementar o preceito constitucional. Pode ocorrer, assim, que a mesma vontade constitucional idônea a estabelecer a imunidade remeta ao legislador infraconstitucional a incumbência de fixar requisitos ou condições para a fruição do benefício. Nesse caso a norma terá eficácia plena até a edição do ato normativo redutor de seu âmbito eficacional - vale dizer, será autêntica norma de eficácia contida ou restringível. ${ }^{391}$
\end{abstract}

Ocorre, no entanto, que, mesmo essa norma imunizante necessitando de regulamentação, os seus efeitos são irradiados tão logo a pessoa, coisa ou situação se enquadre nas hipóteses imunitórias contidas na Constituição Federal de 1988, já que a regra de imunidade possui aplicabilidade imediata.

Tendo em vista que, em tese, a partir da promulgação da Constituição Federal de 1988 não houve a edição de lei específica para tratar da matéria, Fisco e magistrados começaram a aplicar a regra contida no artigo 55 da Lei $\mathrm{n}^{\circ}$ 8.212, de 1991, a qual estabelecia diversos critérios a serem preenchidos pelas entidades beneficentes de assistência social, para fins de gozo da imunidade às contribuições sociais destinadas à seguridade social.

Isso fica muito claro ao se analisar a jurisprudência pátria. A título exemplificativo, cita-se o entendimento exarado pelos integrantes da Primeira Turma do Tribunal Regional Federal da Terceira Região nos autos do Agravo de Instrumento nº 00043011420134030000 :

PROCESSUAL CIVIL. AGRAVO LEGAL NO AGRAVO DE INSTRUMENTO. TRIBUTÁRIO. CONSTITUCIONAL. IMUNIDADE. CONTRIBUIÇÕES SOCIAIS. ENTIDADE BENEFICENTE DE ASSISTÊNCIA SOCIAL. POSIÇÃO CONSOLIDADA NO STF COM REPERCUSSÃO GERAL. REQUISITOS MATERIAIS. MANUTENÇÃO DA DECISÃO IMPUGNADA.

$[\ldots]$

2- [...] . Não se deve confundir a imunidade de impostos prevista no art. 150, VI, "c", da CF, cujos requisitos estão estabelecidos no art. 14 do CTN, com a imunidade de contribuição para a seguridade social, prevista no art. 195, § $7^{\circ}$, da Magna Carta.

$[\ldots]$

5- À falta de regramento específico acerca dos requisitos formais para a obtenção pelas entidades beneficentes de direito público da imunidade do artigo 195, $\S 7^{\circ}$, da CF, aplica-se o disposto no artigo 55 da Lei 8212/91,

${ }^{391}$ COSTA, Regina Helena. Imunidades tributárias - teoria e análise da jurisprudência do STF. 2. ed. São Paulo, Malheiros, 2006. p. 95. 
inclusive após a entrada em vigor do artigo 29 da Lei 12101/2009, apenas no que couber.

6- A imunidade presente e futura, bem como eventuais indébitos desde a expiração da validade do último certificado concedido, depende do CEBAS, atestando a continuidade das condições para o seu gozo. Com o advento da Lei 12101/2009, regulamentada pelo Decreto 7237/2010, o protocolo de requerimento de renovação do CEBAS passou a valer como prova da certificação da entidade até o julgamento do processo pelo Ministério competente, conforme art. $8^{\circ}$ do aludido Decreto.

7- A concessão atual do certificado implica reconhecer que a autora efetivamente preenche todos os requisitos necessários para a sua obtenção estabelecidos pelo art. 29 da Lei 12101/2009 e pelo Decreto 7.237/2010.

[...]

9- Agravo legal a que se nega provimento. ${ }^{392}$

O Supremo Tribunal Federal há muito tempo possui este entendimento ${ }^{393}$. Porém, somos da opinião de que esse posicionamento não merece prosperar. Nossa opinião baseia-se em que, as imunidades tributárias, por serem consideradas "limitações constitucionais ao poder de tributar", só podem ser reguladas por meio de lei complementar, a teor do artigo 146, inciso II da Constituição Federal de 1988, e nunca por intermédio de lei ordinária ${ }^{394}$.

O simples fato de o legislador constituinte não ter feito menção à lei complementar não pode ensejar o entendimento de que a lei citada no artigo $195, \S 7^{\circ}$ da Constituição Federal de 1988 é a ordinária. Ao se interpretar a Constituição de forma sistemática, concluirse-á que essa lei só pode ser a complementar, justamente por força do comando contido no artigo 146, inciso II do Texto Maior.

Apesar de o Congresso Nacional não ter editado lei complementar visando à regulamentação da imunidade tributária do artigo $195, \S 7^{\circ}$ da Constituição Federal de 1988, entendemos que o artigo 14 do Código Tributário Nacional supre essa "lacuna". Afinal, o

\footnotetext{
${ }^{392}$ AI n $^{\circ}$ 00043011420134030000, TRF $3^{\text {a }}$ Região, Rel. Juiz Conv. Hélio Nogueira, DJ-e de 03.06.2014. Disponível em: <www.cjf.jus.br>. Acesso em: 19 nov. 2014.

${ }^{393}$ A título exemplificativo, podem ser citadas as decisões proferidas nos autos da ADI $\mathrm{n}^{\circ} 2.028$, de relatoria do Ministro Moreira Alves (ADI $n^{\circ}$ 2028, STF, Pleno, Min. Moreira Alves, DJ de 16.06.2000. Disponível em: <www.stf.jus.br>. Acesso em: 19 nov. 2014) e, mais recentemente, nos autos do RE n ${ }^{\circ}$ 636.941, de relatoria do Ministro Luiz Fux (RE 636.941, STF, Pleno, Rel. Min. Luiz Fux, DJ-e de 03.04.2014. Disponível em: <www.stf.jus.br>. Acesso em: 19 nov. 2014).

${ }^{394}$ É importante mencionar que a necessidade de edição de lei complementar circunscreve-se às hipóteses de configuração dos requisitos para o gozo da imunidade. Cabe à lei ordinária, por sua vez, regrar, formal e materialmente, a constituição e o funcionamento das entidades beneficentes de assistência social. Dessa forma, se determinada lei ordinária estabelecer requisitos de constituição e de funcionamento das entidades imunes, tal norma jurídica não estará eivada do vício de inconstitucionalidade, já que não estará a estabelecer os requisitos para a fruição das imunidades de ditas entidades.
} 
artigo 14 do Código Tributário Nacional foi recepcionado pela Constituição Federal de 1988 com status de lei complementar, como já afirmamos ${ }^{395}$.

Se esse dispositivo possui tal status e somente lei complementar tem o condão de dispor sobre os requisitos a serem preenchidos pelas entidades imunes visando ao gozo da imunidade, nada mais correto, do ponto de vista jurídico e sistêmico, do que utilizar esse artigo para regulamentar as imunidades tributárias ditas condicionadas, tal qual a imunidade às contribuições sociais destinadas à seguridade social das entidades beneficentes de assistência social.

Este, inclusive, é o posicionamento de Leandro Pacheco Scherer:

[...] exigências engendradas pelo Instituto Nacional do Seguro Social, sob o escudo do art. 55, da Lei n. 8.212, de 1991, com a redação atribuída pela Lei n. 9.732, de 1998, revelam-se, às escâncaras, de uma ilegalidade insuprível, visto que estabelecem óbices indevidos para impedir que as entidades beneficentes de assistência social fruam da imunidade tributária para, por evidente, cobrar-lhes as contribuições... Todavia, as exigências legais que as entidades beneficentes de assistência social devem atender são aquelas insertas no art. 14 do Código Tributário Nacional. Nada mais. Essas são as únicas exigências legais que o Instituto Nacional do Seguro Social tem a obrigação de averiguar e reclamar, porquanto a Constituição, em seu art. 146, II, repise-se, determina que cabe à lei complementar regulamentar as limitações constitucionais ao poder de tributar. ${ }^{396}$

Assim, se as imunidades tributárias correspondem às limitações constitucionais ao poder de tributar e essas, nos termos do artigo 146, inciso II da Constituição Federal de 1988, só podem ser reguladas por meio de lei complementar, constata-se que, por inexistir, atualmente, outra lei complementar que trate da matéria afora o Código Tributário Nacional, os requisitos a serem adimplidos pelas entidades beneficentes de assistência social para o

\footnotetext{
${ }^{395}$ Sobre esse assunto, Leandro Paulsen externou o seguinte entendimento: "Este artigo 14 do CTN foi recepcionado pela Constituição de 1988, estabelecendo os únicos requisitos ou condições materiais exigíveis para o gozo da imunidade prevista no art. 150, VI, c, da Constituição Federal, nao cabendo à lei ordinária dispor sobre a matéria em razão da reserva decorrente do art. 146, II, da CF. Poderá o legislador ordinário, isto, sim, estabelecer requisitos formais quanto à constituição e funcionamento dos entes imunes." (PAULSEN, Leandro. Direito tributário: Constituição e Código Tributário à luz da doutrina e da jurisprudência. 15. ed. Rio Grande do Sul: Livraria do Advogado, 2013. p. 680.)

${ }^{396}$ SCHERER, Leandro Pacheco. Considerações acerca da imunidade tributária das entidades beneficentes de assistência social. Revista de Estudos Tributários. Porto Alegre, v. 07, n. 39, p. 155, 2004.
} 
gozo da imunidade às contribuições sociais são os dispostos no artigo 14 do Código Tributário Nacional ${ }^{397}$.

O outro argumento utilizado por magistrados e pelo Fisco para afastar a aplicação do artigo 14 do Código Tributário Nacional, às entidades beneficentes de assistência social é o de que esse artigo só se aplica aos impostos, pois o legislador infraconstitucional foi expresso nesse sentido. Entretanto, entendemos que esse simplório argumento não merece prosperar.

Como se não bastasse o artigo 14 combinado com o artigo $9^{\circ}$, ambos do Código Tributário Nacional, fazerem referência somente à imunidade aos impostos, certo é que esses artigos se aplicam, inclusive, às contribuições sociais destinadas à seguridade social.

Primeiro porque, quando da edição do Código Tributário Nacional, em 1966, o ordenamento jurídico pátrio ainda não contemplava a figura das contribuições sociais destinadas à seguridade social. Essas só surgiram com a promulgação da Constituição Federal de 1988. À época, os únicos tributos existentes no sistema tributário brasileiro eram os impostos, as taxas e as contribuições de melhoria.

Em razão de as Constituições pretéritas tratarem da figura das imunidades condicionadas somente em relação aos impostos, era mais do que justificável que o Código Tributário Nacional, ao dispor sobre os critérios a serem preenchidos para fins de gozo das imunidades condicionadas, mencionasse somente as espécies tributárias denominadas impostos.

Segundo porque, na hipótese de inexistir regra específica sobre determinado assunto, a legislação tributária pátria permite o uso da analogia ${ }^{398}$, com vista a preencher as lacunas existentes no sistema.

Após a construção da norma que trata dos requisitos a serem preenchidos pelas entidades beneficentes de assistência social, para fins de fruição da imunidade aos impostos a que o artigo 150, inciso VI, “c” da Constituição Federal refere-se, verifica-se que a mesma só se aplica a essa espécie de tributo, ainda que haja previsão constitucional para que essas

\footnotetext{
${ }^{397}$ Essa também é a conclusão de Regina Helena Costa: "Diante da premissa adotada pela Corte, de que se trata de norma de eficácia limitada, esta última conclusão parece-nos ser a mais acertada, posto ser a imunidade contemplada no art. $195, \S 7^{\circ}$, complementar àquela contida no art. 150 , VI, 'c', no que tange às instituições de assistência social sem fins lucrativos. E se para esta norma os requisitos são os insertos no art. 14 do Código Tributário Nacional, as mesmas exigências são cabíveis para a imunidade em relação a contribuições sociais." (COSTA, Regina Helena. Imunidades tributárias - teoria e análise da jurisprudência do STF. 2. ed. São Paulo: Malheiros, 2006, p. 287).

${ }^{398}$ É importante mencionar que o Código Tributário Nacional, em seu artigo 108, § $1^{\circ}$, impede a utilização da analogia visando à exigência de tributo não previsto em lei:

"Art. 108. Na ausência de disposição expressa, a autoridade competente para aplicar a legislação tributária utilizará sucessivamente, na ordem indicada:

$\S 1^{\circ} \mathrm{O}$ emprego da analogia não poderá resultar na exigência de tributo não previsto em lei."
} 
mesmas instituições usufruam da imunidade às contribuições sociais destinadas à seguridade social.

Ao se tentar construir a norma que trata dos requisitos a serem preenchidos por essas entidades visando ao usufruto da imunidade do artigo $195, \S 7^{\circ}$, constata-se que o ordenamento jurídico pátrio não contemplou expressamente essa hipótese ${ }^{399}$.

Dessa forma, utilizando-se a regra do artigo 108, inciso I do Código Tributário Nacional, o qual dispõe a respeito da utilizada da analogia para fins de integração das normas, verifica-se ser plenamente possível estender a dicção contida nos artigos $9^{\circ}$ e 14 do Código Tributário Nacional às contribuições sociais destinadas à seguridade social.

Portanto, cai por terra o argumento do Fisco e de parte do Poder Judiciário de que os requisitos contidos no Código Tributário Nacional só se aplicam aos impostos, haja vista que os artigos $9^{\circ}$ e 14 desse diploma legal somente se referem a eles e não às demais espécies tributárias.

\subsection{A questão da observância dos requisitos dispostos no artigo 55 , da Lei $\mathbf{n}^{0}$} 8.212, de 1991, para fins de fruição da imunidade às contribuições sociais destinadas à seguridade social das entidades beneficentes de assistência social

Em 21 de julho de 1991, foi publicada a Lei n 8.212, que “dispõe sobre a organização da Seguridade Social, institui Plano de Custeio, e dá outras providências”. Em seu artigo $55^{400}$, essa lei elencou os requisitos que deveriam ser atendidos pelas entidades beneficentes

\footnotetext{
${ }^{399}$ Levando-se em consideração que as imunidades tributárias às contribuições sociais destinadas à seguridade social das entidades beneficentes de assistência social só podem ser tratadas via lei complementar.

400 "Art. 55. Fica isenta das contribuições de que tratam os arts. 22 e 23 desta Lei a entidade beneficente de assistência social que atenda aos seguintes requisitos cumulativamente:

I - seja reconhecida como de utilidade pública federal e estadual ou do Distrito Federal ou municipal;

II - seja portadora do Certificado e do Registro de Entidade de Fins Filantrópicos, fornecido pelo Conselho Nacional de Assistência Social, renovado a cada três anos;

III - promova, gratuitamente e em caráter exclusivo, a assistência social beneficente a pessoas carentes, em especial a crianças, adolescentes, idosos e portadores de deficiência;

IV - não percebam seus diretores, conselheiros, sócios, instituidores ou benfeitores, remuneração e não usufruam vantagens ou benefícios a qualquer título;

$\mathrm{V}$ - aplique integralmente o eventual resultado operacional na manutenção e desenvolvimento de seus objetivos institucionais apresentando, anualmente ao órgão do INSS competente, relatório circunstanciado de suas atividades.

$\S 1^{\circ}$ Ressalvados os direitos adquiridos, a isenção de que trata este artigo será requerida ao Instituto Nacional do Seguro Social-INSS, que terá o prazo de 30 (trinta) dias para despachar o pedido.

$\S 2^{\circ} \mathrm{A}$ isenção de que trata este artigo não abrange empresa ou entidade que, tendo personalidade jurídica própria, seja mantida por outra que esteja no exercício da isenção.

$\S 3^{\circ}$ Para os fins deste artigo, entende-se por assistência social beneficente a prestação gratuita de benefícios e serviços a quem dela necessitar.

$\S 4^{\circ} \mathrm{O}$ Instituto Nacional do Seguro Social - INSS cancelará a isenção se verificado o descumprimento do disposto neste artigo.
} 
de assistência social para fins de fruição da "isenção" das contribuições de que tratam os artigos 22 e 23 dessa mesma lei.

De acordo com esse dispositivo legal, as entidades beneficentes de assistência social deveriam preencher os seguintes pressupostos, a fim de obter o benefício da imunidade às contribuições sociais destinadas à seguridade social:

1. ser reconhecida como de utilidade pública federal, estadual, do distrito federal ou municipal;

2. portar o Certificado e o Registro de Entidade de fins filantrópicos, emitidos pelo Conselho Nacional de Assistência Social, o qual seria renovado a cada três anos;

3. prestar serviços, na área da assistência social, de forma gratuita e em caráter exclusivo, às pessoas necessitadas, especialmente às crianças, aos adolescentes, aos idosos e aos portadores de deficiência;

4. não remunerar, nem, tampouco, conceder vantagens ou benefícios a seus diretores, conselheiros, instituidores ou benfeitores;

5. aplicar seu superávit nos objetivos sociais da instituição e apresentar, anualmente, ao órgão competente do extinto INSS, relário demonstrativo de suas atividades;

6. prestar serviços ao SUS em percentual igual ou superior a sessenta por cento dos préstimos realizados; e

7. não possuir quaisquer débitos em relação às contribuições sociais.

Conforme se verifica pela leitura da transcrição acima, o artigo 55, da Lei $n^{\circ}$ 8.212/91, além de extrapolar os requisitos para a fruição da imunidade contidos no artigo 14 do Código Tributário Nacional, alterou o conceito de entidade beneficente de assistência social contido na Constituição Federal de 1988.

Tal qual mencionado, as imunidades tributárias somente podem ser regulamentadas via lei complementar e nunca por intermédio de lei ordinária, de modo que o artigo 55 da Lei $\mathrm{n}^{\circ} 8.212 / 91$, naquilo que conflitar com o artigo 14 do Código Tributário Nacional e com a própria Constituição Federal, deverá ser declarado inconstitucional.

$\S 5^{\circ}$ Considera-se também de assistência social beneficente, para os fins deste artigo, a oferta e a efetiva prestação de serviços de pelo menos sessenta por cento ao Sistema Único de Saúde, nos termos do regulamento. $\S 6^{\circ} \mathrm{A}$ inexistência de débitos em relação às contribuições sociais é condição necessária ao deferimento e à manutenção da isenção de que trata este artigo, em observância ao disposto no $\S 3^{\circ}$ do art. 195 da Constituição." 
Entendemos que a declaração de utilidade pública ${ }^{401}$, bem como o certificado e o registro de entidade de fins filantrópicos ${ }^{402}$, não podem ser exigidos como requisitos permissivos da aplicação da imunidade às contribuições sociais destinadas à seguridade social das entidades beneficentes de assistência social. A causa disso é que, para que esses documentos fossem expedidos, a entidade interessada deveria estar constituída no país, possuir personalidade jurídica, não remunerar seus dirigentes, etc. Ou seja, observar requisitos que vão muito além do que exige a Constituição Federal para reconhecimento das entidades beneficentes de assistência social. Retomando a concepção já dada, para que se enquadre no conceito de entidade beneficente de assistência social basta que a instituição não possua fins lucrativos, preste serviços de relevante interesse público a quem deles precisar e o faça de forma gratuita a pessoas carentes e necessitadas.

Assim, ao exigir-se que outros requisitos sejam preenchidos além dos mencionados acima, a Lei $n^{\circ} 8.212$ esvaziou o conceito de entidade beneficente de assistência social, de modo que a obtenção ou não da declaração de utilidade pública ou o Certificado CNAS é irrelevante para a caracterização da imunidade tributária às contribuições sociais destinadas à seguridade social.

É justamente por este motivo que Aires Fernandino Barreto e Paulo Ayres Barreto declaram que uma entidade pode ser declarada de utilidade pública sem ser imune, e uma instituição imune pode não ser declarada de utilidade pública:

Note-se que uma entidade pode ser declarada de utilidade pública sem ser imune. E, inversamente, uma entidade imune pode não ser declarada de utilidade pública. Não ser declarada de utilidade pública não afeta a imunidade a que faça jus. De fato, como os requisitos para uma entidade ser declarada de utilidade pública são diferentes daqueles previstos no art. 14, do CTN, para o reconhecimento de imunidade pode ter-se que instituição imune não venha a ser declarada de utilidade pública (por exemplo, se não adquiriu personalidade jurídica há mais de um ano, como exige a Lei 11.295, do Município de São Paulo). ${ }^{403}$

\footnotetext{
${ }^{401}$ Entede-se por declaração de utilidade pública o ato pelo qual o Poder Público, federal, estadual, distrital ou municipal assegura que determinada entidade é idônea e possui seus objetivos voltados à satisfação de um interesse de utilidade pública, na sua específica área de atuação.

${ }^{402}$ O Certificado e Registro de Entidade de Fins Filantrópicos fornecido pelo Conselho Nacional de Assistência Social (Certificado CNAS) estava previsto no Decreto ${ }^{\circ} 2.536$, de 1998. Tal Decreto foi revogado em 2010 pelo Decreto 7.237, que, por sua vez, foi revogado pelo Decreto 8.242, de 2014, o qual "regulamenta a Lei n. 12.101, de 27 de novembro de 2009, para dispor sobre o processo de certificação das entidades beneficentes de assistência social e sobre procedimentos de isenção das contribuições para a seguridade social".

${ }^{403}$ BARRETO; BARRETO, op. cit., p. 79.
} 
Também entendemos que a exigência de prestação de serviço de forma gratuita e em caráter exclusivo, bem com a exigência de destinação de sessenta por cento de seus serviços ao SUS, fere o texto constitucional, uma vez que as entidades beneficentes de assistência social não só podem como devem cobrar pela prestação de seus serviços daqueles que podem pagar.

A jurisprudência pátria já reconheceu que essa gratuidade não precisa ser absoluta, mas sim relativa. Desse modo, se a entidade beneficente de assistência social cobrar daqueles que podem pagar pelos seus préstimos e prestar serviços de forma totalmente gratuita aos carentes e necessitados, mantida estará a sua imunidade às contribuições sociais à seguridade social. Assim, a exigência de prestação de, no mínimo, sessenta por cento de seus serviços de forma gratuita ao SUS, padece do vício de inconstitucionalidade.

A questão da remuneração do corpo diretivo da entidade beneficente de assistência social também está definida não só na doutrina, mas também na jurisprudência. Isso significa dizer que o dirigente da entidade imune pode sim perceber remuneração pelos serviços prestados. O que se veda é o pagamento dessa remuneração em patamares muito superiores aos que o mercado remunera. Mantida essa coerência, preservada estará a imunidade.

Por fim, mas não menos importante, a impossibilidade de existência de quaisquer débitos em relação às contribuições sociais também não possui supedâneo legal, pois as normas aplicáveis às entidades imunes em momento algum estabelecem a necessidade de a instituição imune não possuir débitos a título de contribuições sociais, sob pena de suspensão do benefício constitucional.

Após muitas discussões doutrinárias e jurisprudencias, a CNS (Confederação Nacional de Saúde - Hospitais, Estabelecimentos e Serviços) ajuizou a ADI n 2.028, por meio da qual requereu a declaração de inconstitucionalidade do artigo 55, inciso $\mathrm{III}^{404}$, parágrafos $3^{\mathrm{o} 405}$, $4^{\text {o406 }}$ e $5^{\text {o407 }}$ da Lei $n^{\text {o }} 8.212 / 1991$, dentre outros dispositivos legais.

\footnotetext{
404 “III - promova, gratuitamente e em caráter exclusivo, a assistência social beneficente a pessoas carentes, em especial a crianças, adolescentes, idosos e portadores de deficiência."

405 " $\$ 3^{\circ}$ Para os fins deste artigo, entede-se por asssitência social beneficente a prestação gratuita de benefícios e serviços a quem dela necessitar."

406 “乌 $4^{\circ}$ O Instituto Nacional do Seguro Social - INSS cancelará a isenção se verificado o descumprimento do disposto neste artigo."

407 "§ $5^{\circ}$ Considera-se também de assistência social beneficente, para os fins deste artigo, a oferta e a efetiva prestação de serviços de pelo menos sessenta por cento ao Sistema Único de Saúde, nos termos do regulamento."
} 
Posteriormente, por meio da $\mathrm{ADI} \mathrm{n}^{\mathrm{o}}$ 2.228, a CNS requereu a declaração de inconstitucionalidade do artigo 55, incisos II $^{408}$ e III da Lei $\mathrm{n}^{\text {o }} 8.212 / 1991$, dentre outros dispositivos legais.

Ambas ADIs, juntamente com o Recurso Extraordinário $\mathrm{n}^{\circ} 566.622$, erigido à condição de repercussão geral, e com as ADIs ${ }^{\text {os }} 2.036$ e 2.632 discutem, dentre outros dispositivos, se o artigo 55 da Lei $\mathrm{n}^{\circ}$ 8.212, de 1991, possui o condão de regulamentar as imunidades às contribuições sociais destinadas à seguridade social.

Sobre essa questão trataremos de forma mais aprofundada no item abaixo.

\subsubsection{O julgamento do Recurso Extraordinário no 566.622 e das Ações Diretas de} Inconstitucionalidade $\mathrm{n}^{\mathrm{os}} \mathbf{2 . 0 2 8}, \mathbf{2 . 0 3 6}, \mathbf{2 . 6 2 1}$ e 2.228

Objetivando desconstituir o crédito tributário com vista a exigir-lhe o recolhimento da contribuição previdenciária cota patronal, a Sociedade Beneficente de Parobé ingressou com Ação Anulatória de Débito Fiscal, na qual argumentou ser entidade beneficente de assistência social, o que, nos termos do artigo $195, \S 7^{\circ}$, da Constituição Federal de 1988, ensejaria o afastamento da exigência desse tributo sob o argumento de aplicação de regra imunitória.

Nessa oportunidade, alegou-se que os únicos requisitos a serem preenchidos para fins de fruição dessa hipótese imunitória são os contidos no artigo 14 do Código Tributário Nacional, em total atendimento ao que dispõe o artigo 146, inciso II da Constituição Federal de 1988.

O juízo monocrático, ao analisar o pedido formulado pela Sociedade Beneficente de Parobé, entendeu por bem julgar o feito procedente e determinar a aplicação da regra de imunidade contida no artigo $195, \S 7^{\circ}$ da Constituição Federal de 1988, já que essa entidade preenchia todos os pressupostos contidos no artigo 14, do Código Tributário Nacional.

Irresignado com essa decisão, o extinto Instituto Nacional do Seguro Social (INSS) ${ }^{409}$ interpôs o competente Recurso de Apelação, o que redundou na prolação, por parte dos integrantes da Primeira Turma do Egrégio Tribunal Regional Federal da Quarta Região, do seguinte acórdão:

\footnotetext{
408 "II - seja portadora do Certificado e do Registro de Entidade de Fins Filantrópicos, fornecido pelo Conselho Nacional de Assistência Social, renovado a cada três anos"

${ }^{409}$ Por conta da Lei ${ }^{\circ} 11.457$, de 16 de março de 2007, o INSS deixou de existir e passou a integrar a Receita Federal do Brasil, no que se denominou de "Super Receita".
} 
"TRIBUTÁRIO. CONSTITUCIONAL. IMUNIDADE. ISENÇÃO. CONTRIBUIÇÃO PREVIDENCIÁRIA. ENTIDADE HOSPITALAR. ART. 195, § $7^{\circ}$, DA CONSTITUIÇÃO FEDERAL. CERTIFICADOS EXPEDIDOS PELO PODER PÚBLICO. EFICÁCIA. AUSÊNCIA DE PROVA DO IMPLEMENTO DOS REQUISITOS LEGAIS.

1. O art. $195, \S 7^{\circ}$, da Constituição Federal, ao remeter à lei a disciplina sobre as exigências legais para a concessão da imunidade, o fez de forma genérica, sem referir-se à lei complementar, motivo pelo qual pode ser regulado por lei ordinária, desde que não haja distorção do conceito constitucional de entidade beneficente de assistência social, nem limitação da extensão do benefício constitucional. Com efeito, não se aplica, na espécie, o art. 14 do CTN, por referir-se a impostos e existir, em relação às contribuições sociais para a seguridade social, norma legal específica. Ressalve-se, contudo, que a aplicação dos arts. $1^{\circ}, 4^{\circ}, 5^{\circ}$ e $7^{\circ}$ da Lei $n$. 9.732/98, foi afastada pelo STF, uma vez que restringem, materialmente, as hipóteses de imunidade estabelecidas pela Constituição (ADIn 2.028, rel. Min. Moreira Alves, j. 11.11.99).

2. Conquanto os certificados expedidos pelo Poder Público tenham eficácia meramente declaratória e constituam prova pré-constituída de situação fática que pode ser, por outros meios, comprovada pelo postulante do benefício fiscal, não há nos autos elementos que permitam inferir o momento em que a entidade implementou os requisitos legais para a concessão do benefício fiscal, a fim de conferir à prova documental eficácia retroativa.. ${ }^{, 410}$

Conforme se verifica pela leitura do acórdão acima transcrito, o Tribunal Regional Federal da Quarta Região deu provimento ao Recurso de Apelação do extinto INSS sob três principais argumentos:

1. o de que o artigo 195, $\S 7^{\circ}$ da Constituição Federal de 1988, ao mencionar que farão jus à imunidade as entidades beneficentes de assistência social que preencherem os requisitos contidos em lei, o fez de forma genérica, sem, contudo, referir-se à lei complementar;

2. o de que o artigo 14 do Código Tributário Nacional aplica-se somente aos impostos e não às demais espécies tributárias; e

3. o de que existe norma específica estabelecendo os requisitos para fruição da imunidade das contribuições sociais destinadas à seguridade social: o artigo 55 da Lei n. 8.212.

Não se conformando com essa decisão, a Sociedade Beneficente de Parobé interpôs seu Recurso Extraordinário, em 25 de julho de 2007, no qual alegou que o acórdão proferido pelos integrantes da Primeira Turma do Tribunal Regional Federal da Quarta Região

\footnotetext{
${ }^{410} \mathrm{AC} \mathrm{n}^{\mathrm{o}}$ 2005.04.01.025104-0, TRF 4 ${ }^{\mathrm{a}}$ Região, $1^{\mathrm{a}}$ Turma, Rel(a). Juíza Conv. Vivian Josete Pantaleão Caminha, DJ de 08.03.2006. Disponível em: <www.cjf.jus.br>. Acesso em: 08 nov. 2014.
} 
contrariou os dispositivos contidos nos artigos 146, inciso II e $195, \S 7^{\circ}$, ambos da Constituição Federal de 1988.

Isso porque, por tratar-se de "limitação constitucional ao poder de tributar", as normas que tratam dos requisitos de fruição das hipóteses de imunidade tributária só podem ser veiculadas por meio de lei complementar e nunca por intermédio de lei ordinária.

Após o juízo de admissibilidade desse Recurso Extraordinário, o mesmo foi distribuído no Supremo Tribunal Federal, em 10 de outubro de 2007, sob o no 566.622 e sob a relatoria do Ministro Marco Aurélio.

Em 18 de janeiro de 2008, o Supremo Tribunal Federal, por meio do Relator do Recurso Extraordinário $n^{\circ} 566.622$, reconheceu a existência de repercussão geral da questão constitucional suscitada e determinou que a decisão prolatada nos autos desse Apelo Extraordinário teria efeito vinculante a todas as demais decisões a serem proferidas pelos integrantes do Poder Judiciário pátrio ${ }^{411}$. Após um longo período em que foram proferidos somente despachos de mero expediente, os autos desse Recurso Extraordinário foram incluídos na pauta de julgamento do dia 4 de junho de 2014.

Além do julgamento do RE $n^{\circ}$ 566.622, o Supremo Tribunal Federal, nessa mesma oportunidade, deu início ao julgamento do mérito das ADIs $n^{\text {os }} .2 .028,2.036,2.621$ e 2.228.

\footnotetext{
411 “REPERCUSSÃO GERAL - ENTIDADE BENEFICENTE DE ASSISTÊNCIA SOCIAL - IMUNIDADE CONTRIBUIÇÕES SOCIAIS - ARTIGO 195, § $7^{\circ}$, DA CONSTITUIÇÃO FEDERAL.

1. O Tribunal Regional Federal da $4^{a}$ Região negou provimento à apelação da recorrente e proveu o apelo da União, assentando que o artigo $195, \S 7^{\circ}$, da Constituição Federal, ao remeter à lei a disciplina sobre as exigências para a concessão da imunidade às entidades beneficentes de assistência social, assim o fez de forma genérica, sem referir-se a lei complementar, motivo pelo qual pode ser regulado por lei ordinária. No extraordinário interposto com alegada base na alínea a do permissivo constitucional, a recorrente articula com a transgressão dos artigos 146, inciso II, e $195, \S 7^{\circ}$, do Diploma Maior. Aduz ter jus ao gozo da imunidade tributária, quanto ao recolhimento de contribuições previdenciárias, considerado o fato de o $\S 7^{\circ}$ do artigo 195 da Carta veicular verdadeira regra de não-incidência. Diz da inconstitucionalidade formal do artigo 55 da Lei ${ }^{\circ}$ 8.212/91. Em face do disposto no inciso II do artigo 146 da Constituição Federal, entende aplicáveis à espécie os requisitos previstos no artigo 14 do Código Tributário Nacional, aos quais, conforme consignado no acórdão de origem, atendeu plenamente. Sob o ângulo da repercussão geral, sustenta a importância do tema, ante a circunstância de a orientação a ser definida pelo Supremo vir a nortear o julgamento de diversos processos semelhantes, superando o interesse subjetivo. Afirma a relevância jurídica da questão constitucional, considerado o fato de as entidades beneficentes desempenharem função social de grande valor, mormente em relação às camadas carentes da sociedade.

2. Está-se diante de articulação sobre a harmonia do artigo 55 da Lei $\mathrm{n}^{\circ}$ 8.212/91 com o ordenamento jurídicoconstitucional. A matéria possui relevância, tendo em conta as entidades beneficentes que atuam no campo social.

3. Admito a repercussão, a fim de que o pronunciamento do Supremo sobre a higidez, ou não, do artigo 55 da Lei $\mathrm{n}^{\circ} 8.212 / 91$ ganhe contornos vinculantes.

4. Publiquem."
} 
Nos autos da ADI no $2.028^{412}$, a CNS (Confederação Nacional de Saúde - Hospitais, Estabelecimentos e Serviços) requereu a declaração de inconstitucionalidade do artigo 55, inciso III ${ }^{413}$ da Lei $n^{\mathrm{o}} 8.212 / 1991$ e dos parágrafos $3^{\mathrm{o} 414}, 4^{\mathrm{o} 415}$ e $5^{\mathrm{o} 416}$ do referido artigo; e $\operatorname{artigos} 4^{\mathrm{o}^{417}}, 5^{\mathrm{o} 418}$ e $7^{\mathrm{o} 419}$ da Lei $\mathrm{n}^{\mathrm{o}} 9.732 / 1998$.

Por sua vez, por meio da ADIN no $2.036^{420}$, a CONFENEM (Confederação Nacional dos Estabelecimentos de Ensino) pretendeu ver declarada a inconstitucionalidade dos artigos $1^{\mathrm{o} 421}, 4^{\mathrm{o}}$ e $5^{\mathrm{o}}$, todos da Lei $\mathrm{n}^{\mathrm{o}} 9.732 / 1998$.

$\mathrm{Na}$ ADI $\mathrm{n}^{\circ} 2.621^{422}$ ajuizada pela CNS, que requereu a sua distribuição por dependência à $\mathrm{ADI} \mathrm{n}^{\mathrm{o}}$ 2.028, pleiteiou-se a declaração de inconstitucionalidade dos artigos $3^{\mathrm{o} 423}$ e $5^{\mathrm{o}^{424}}$, da MP $\mathrm{n}^{\mathrm{o}} 2.187-13 / 2001 ; \operatorname{artigos} 2^{\mathrm{o}}, \mathrm{IV}^{425}, \S 3^{\mathrm{o}}, \mathrm{VI}^{426}, \S \S 1^{\mathrm{o} 427}$ e $4^{\mathrm{o} 428}, 4^{\mathrm{o}}$,

$\overline{412}$ O Ministro Marco Aurélio, Relator deste caso, em 14 de julho de 1999, quando da apreciação do pedido de liminar, entendeu por deferi-la para o fim de "suspender a eficácia do artigo $1^{\circ}$, na parte em que alterou a redação do artigo 55, inciso III, da Lei $n^{\circ} 8.212 / 91$ e acrescentou-lhe os $\S \S 3^{\circ}, 4^{\circ}$ e $5^{\circ}$, bem como dos artigos $4^{\circ}, 5^{\circ}$ e $7^{\circ}$ da Lei n ${ }^{\circ} 9.732$, de 11 de dezembro de 1998 ".

413 "III - promova, gratuitamente e em caráter exclusivo, a assistência social beneficente a pessoas carentes, em especial a crianças, adolescentes, idosos e portadores de deficiência."

414 " $\$ 3^{\circ}$ Para os fins deste artigo, entede-se por asssitência social beneficente a prestação gratuita de benefícios e serviços a quem dela necessitar."

415 " $4^{\circ} \mathrm{O}$ Instituto Nacional do Seguro Social - INSS cancelará a isenção se verificado o descumprimento do disposto neste artigo."

416 "§ $5^{\circ}$ Considera-se também de assistência social beneficente, para os fins deste artigo, a oferta e a efetiva prestação de serviços de pelo menos sessenta por cento ao Sistema Único de Saúde, nos termos do regulamento." 417 "Art. $4^{\circ}$ As entidades sem fins lucrativos educacionais e as que atendam ao Sistema Único de Saúde, mas não pratiquem de forma exclusiva e gratuita atendimento a pessoas carentes, gozarão da isenção das contribuições de que tratam os arts. 22 e 23 da Lei $n^{\circ} 8.212$, de 1991, na proporção do valor das vagas cedidas, integral e gratuitamente, a carentes e do valor do atendimento à saúde de caráter assistencial, desde que satisfaçam os requisitos referidos nos incisos I, II, IV e V do art. 55 da citada Lei, na forma do regulamento."

418 "Art. $5^{\circ} \mathrm{O}$ disposto no art. 55 da Lei ${ }^{\circ} 8.212$, de 1991, na sua nova redação, e no art. $4^{\circ}$ desta Lei terá aplicação a partir da competência abril de 1999."

419 “Art. $7^{\circ}$ Fica cancelada, a partir de $1^{\circ}$ de abril de 1999 , toda e qualquer isenção concedida, em caráter geral ou especial, de contribuição para a Seguridade Social em desconformidade com o art. 55 da Lei no 8.212 , de 1991, na sua nova redação, ou com o art. $4^{\circ}$ desta Lei."

${ }^{420}$ Por conta da prolação de decisão nos autos da ADIN 2.028, que também tratou da questão dos requisitos a serem preeenchidos, para fins de fruição da imunidade tributária às contribuições sociais destinadas à seguridade social, das entidades beneficentes de assistência social, o STF, em 11 de novembro de 1999, tendo o Ministro Celso de Mello como Relator da ADI 2.036, "por unanimidade, julgou prejudicado o pedido de medida liminar, tendo em vista a concessão da liminar na ADIn n ${ }^{\circ} 2.028-5$ ".

421 "Art. $1^{\circ}$ Os arts. 22 e 55 da Lei $n^{\circ} 8.212$, de 24 de julho de 1991, passam a vigorar com as seguintes alterações:"

${ }^{422}$ Apesar de a ADI ${ }^{\circ} 2.621$ conter pedido de concessão de liminar, tal pleito não foi analisado pelo Relator do feito, Ministro Joaquim Barbosa, para quem os autos foram distribuídos após a aposentadoria do Ministro Moreira Alves, responsável originário pela análise dessa ADI.

423 "Art. 3 - Os dispositivos adiante indicados da Lei $\mathrm{n}^{\circ}$ 8.212, de 24 de julho de 1991, passam a vigorar com a seguinte redação: (Revogado pela Lei ${ }^{\circ} 12.101$, de 2009)

"Art. 38.

$\S 10$. O acordo celebrado com o Estado, o Distrito Federal ou o Município conterá, ainda, cláusula em que estes autorizem, quando houver a falta de pagamento de débitos vencidos ou de prestações de acordos de parcelamento, a retenção do Fundo de Participação dos Estados - FPE ou do Fundo de Participação dos Municípios - FPM e o repasse ao Instituto Nacional do Seguro Social - INSS do valor correspondente à mora, 
por ocasião da primeira transferência que ocorrer após a comunicação da autarquia previdenciária ao Ministério da Fazenda.

$\S 12$. O acordo previsto neste artigo conterá cláusula em que o Estado, o Distrito Federal e o Município autorize a retenção do FPE e do FPM e o repasse à autarquia previdenciária do valor correspondente às obrigações previdenciárias correntes do mês anterior ao do recebimento do respectivo Fundo de Participação.

$\S$ 13. Constará, ainda, no acordo mencionado neste artigo, cláusula em que o Estado, o Distrito Federal ou o Município autorize a retenção pelas instituições financeiras de outras receitas estaduais, distritais ou municipais nelas depositadas e o repasse ao INSS do restante da dívida previdenciária apurada, na hipótese em que os recursos oriundos do FPE e do FPM não forem suficientes para a quitação do parcelamento e das obrigações previdenciárias correntes.

$\S 14$. O valor mensal das obrigações previdenciárias correntes, para efeito deste artigo, será apurado com base na respectiva Guia de Recolhimento do Fundo de Garantia do Tempo de Serviço e de Informações à Previdência Social - GFIP ou, no caso de sua não-apresentação no prazo legal, estimado, utilizando-se a média das últimas doze competências recolhidas anteriores ao mês da retenção prevista no $§ 12$ deste artigo, sem prejuízo da cobrança ou restituição ou compensação de eventuais diferenças." (NR)

"Art.55.

II - seja portadora do Registro e do Certificado de Entidade Beneficente de Assistência Social, fornecidos pelo Conselho Nacional de Assistência Social, renovado a cada três anos; (Revogado pela Medida Provisória n 446, de 2008) Rejeitada (Revogado pela Lei $\mathrm{n}^{\circ}$ 12.101, de 2009)

$\S 6^{\circ} \mathrm{A}$ inexistência de débitos em relação às contribuições sociais é condição necessária ao deferimento e à manutenção da isenção de que trata este artigo, em observância ao disposto no $\S 3^{\circ}$ do art. 195 da Constituição." (NR) (Revogado pela Medida Provisória $n^{\circ} 446$, de 2008) Rejeitada (Revogado pela Lei $\mathrm{n}^{\circ} 12.101$, de 2009) "Art.55

II - seja portadora do Registro e do Certificado de Entidade Beneficente de Assistência Social, fornecidos pelo Conselho Nacional de Assistência Social, renovado a cada três anos; (Revogado pela Lei $\mathrm{n}^{\circ}$ 12.101, de 2009)

$\S 6^{\circ} \mathrm{A}$ inexistência de débitos em relação às contribuições sociais é condição necessária ao deferimento e à manutenção da isenção de que trata este artigo, em observância ao disposto no $\S 3^{\circ}$ do art. 195 da Constituição." (NR) (Revogado pela Lei ${ }^{\circ} 12.101$, de 2009)

"Art. 68.

$\S 3^{\circ}$ A comunicação deverá ser feita por meio de formulários para cadastramento de óbito, conforme modelo aprovado pelo Ministério da Previdência e Assistência Social.

$\S 4^{\circ}$ No formulário para cadastramento de óbito deverá constar, além dos dados referentes à identificação do Cartório de Registro Civil de Pessoas Naturais, pelo menos uma das seguintes informações relativas à pessoa falecida:

a) número de inscrição do PIS/PASEP;

b) número de inscrição no Instituto Nacional do Seguro Social - INSS, se contribuinte individual, ou número de benefício previdenciário - NB, se a pessoa falecida for titular de qualquer benefício pago pelo INSS;

c) número do CPF;

d) número de registro da Carteira de Identidade e respectivo órgão emissor;

e) número do título de eleitor;

f) número do registro de nascimento ou casamento, com informação do livro, da folha e do termo;

g) número e série da Carteira de Trabalho." (NR)

"Art. 102. Os valores expressos em moeda corrente nesta Lei serão reajustados nas mesmas épocas e com os mesmos índices utilizados para o reajustamento dos benefícios de prestação continuada da Previdência Social.

Parágrafo único. O reajuste dos valores dos salários-de-contribuição em decorrência da alteração do salário mínimo será descontado quando da aplicação dos índices a que se refere o caput." (NR)"

${ }^{424}$ Art. 5. A Lei n ${ }^{\circ} 8.742$, de 7 de dezembro de 1993, passa a vigorar com as seguintes alterações:

"Art.9......

$\S 3^{\circ}$ A inscrição da entidade no Conselho Municipal de Assistência Social, ou no Conselho de Assistência Social do Distrito Federal, é condição essencial para o encaminhamento de pedido de registro e de certificado de 
parágrafo único ${ }^{429}$, do Decreto $\mathrm{n}^{\mathrm{o}} 2.536 / 1998$; e, subsidiariamente, dos artigos $1^{\mathrm{o}}, \mathrm{IV}^{430}, 2^{\circ}$, $\mathrm{IV}^{431}, \S \S 1^{\mathrm{o} 432}$ e $3^{\mathrm{o} 433}, 7^{\mathrm{o}}, \S 4^{\mathrm{o}}$, todos do Decreto $\mathrm{n}^{\mathrm{o}} 752 / 1993$.

entidade beneficente de assistência social junto ao Conselho Nacional de Assistência Social - CNAS. (Revogado pela Medida Provisória $\mathrm{n}^{\circ}$ 446, de 2008) Rejeitada (Revogado pela Lei $\mathrm{n}^{\circ}$ 12.101, de 2009) (NR)

"Art.18.

III - observado o disposto em regulamento, estabelecer procedimentos para concessão de registro e certificado de entidade beneficente de assistência social às instituições privadas prestadoras de serviços e assessoramento de assistência social que prestem serviços relacionados com seus objetivos institucionais; (Revogado pela Medida Provisória $\mathrm{n}^{\circ}$ 446, de 2008) Rejeitada (Revogado pela Lei $\mathrm{n}^{\circ}$ 12.101, de 2009) IV - conceder registro e certificado de entidade beneficente de assistência social; (Revogado pela Medida Provisória $\mathrm{n}^{\mathrm{o}} 446$, de 2008) Rejeitada (Revogado pela Lei $\mathrm{n}^{\circ} 12.101$, de 2009) " (NR)

Art. $9^{\circ}$

$\S 3^{\circ}$ A inscrição da entidade no Conselho Municipal de Assistência Social, ou no Conselho de Assistência Social do Distrito Federal, é condição essencial para o encaminhamento de pedido de registro e de certificado de entidade beneficente de assistência social junto ao Conselho Nacional de Assistência Social - CNAS. (Revogado pela Medida Provisória $\mathrm{n}^{\circ}$ 446, de 2008) (Revogado pela Lei $\mathrm{n}^{\circ}$ 12.101, de 2009)

"Art.18. " (NR)

III - observado o disposto em regulamento, estabelecer procedimentos para concessão de registro e certificado de entidade beneficente de assistência social às instituições privadas prestadoras de serviços e assessoramento de assistência social que prestem serviços relacionados com seus objetivos institucionais; (Revogado pela Medida Provisória $\mathrm{n}^{\circ}$ 446, de 2008) (Revogado pela Lei $\mathrm{n}^{\circ} 12.101$, de 2009) IV - conceder registro e certificado de entidade beneficente de assistência social; (Revogado pela Medida Provisória $\mathrm{n}^{\circ} \quad 446$, de 2008) (Revogado pela Lei $\mathrm{n}^{\circ} 12.101$, de 2009) " (NR)

"Art. 28-A. Constitui receita do Fundo Nacional de Assistência Social, o produto da alienação dos bens imóveis da extinta Fundação Legião Brasileira de Assistência." (NR)"

425 "Art $.2^{\circ}$ - Considera-se entidade beneficente de assistência social, para os fins deste Decreto, a pessoa jurídica de direito privado, sem fins lucrativos, que atue no sentido de:

IV - promover, gratuitamente, assistência educacional ou de saúde;"

426 "Art . $3^{\circ}-$ Faz jus ao Certificado de Entidade de Fins Filantrópicos a entidade beneficente de assistência social que demonstre, nos três anos imediatamente anteriores ao requerimento, cumulativamente: VI - aplicar anualmente, em gratuidade, pelo menos vinte por cento da receita bruta proveniente da venda de serviços, acrescida da receita decorrente de aplicações financeira, de locação de bens, de venda de bens não integrantes do ativo imobilizado e de doações particulares, cujo montante nunca será inferior à isenção de contribuições sociais usufruída;"

427 “ $\$ 1^{\circ}$ O Certificado de Entidade de Fins Filantrópicos somente será fornecido a entidade cuja prestação de serviços gratuitos seja permanente e sem qualquer discriminação de clientela, de acordo com o plano de trabalho de assistência social apresentado e aprovado pelo CNAS."

428 “ $\$ 4^{\circ} \mathrm{O}$ disposto no inciso VI não se aplica à entidade da área de saúde, a qual, em substituição àquele requisito, deverá comprovar, anualmente, percentual de atendimentos decorrentes de convênio firmado com o Sistema Único de Saúde - SUS igual ou superior a sessenta por cento de total de sua capacidade instalada."

429 “'Art . $4^{\circ}$ - Para fins do cumprimento do disposto neste Decreto, a pessoa jurídica deverá apresentar ao CNAS, além do relatório de execução de plano de trabalho aprovado, pelo menos, as seguintes demonstrações contábeis e financeiras, relativas aos três últimos exercícios:

Parágrafo único. Nas notas explicativas, deverão estar evidenciados o resumo das principais práticas contábeis e os critérios de apuração do total das receitas, das despesas, das gratuidades, das doações, das subvenções e das 
Por fim, mas não menos importante, nos autos da ADI $n^{\circ} 2.228^{434}$, a CNS requereu a declaração de inconstitucionalidade do artigo 55, incisos II $^{435}$ e III da Lei $n^{\circ} 8.212 / 1991$; artigo 18, III ${ }^{436} \mathrm{e} \mathrm{IV}^{437}$ da Lei $n^{\circ} 8.742 / 1993$; artigo $2^{\circ}$, IV, artigo $3^{\circ}$, VI, $\S \S 1^{\circ}$ e $4^{\circ}$ e artigo $4^{\circ}$, parágrafo único do Decreto $n^{\circ} 3.536 / 1998$; e artigo $1^{\circ}$, IV, artigo $2^{\circ}, I V, \S \S 1^{\circ}$ e $3^{\circ}$ e artigo $7^{\circ}$, $\S 4^{\mathrm{o}}$, todos do Decreto $\mathrm{n}^{\mathrm{o}} 752 / 1993$.

Retomando a questão da análise do $\operatorname{RE~n}^{\circ} 566.622$, após a leitura de um longo voto, o Ministro Relator, Marco Aurélio, entendeu por dar provimento ao Recurso Extraordinário interposto pela Sociedade Beneficente de Parobé para, "declarando a inconstitucionalidade formal do artigo 55 da Lei $\mathrm{n}^{\circ}$ 8.212/1991, restabelecer o entendimento constante da sentença e assegurar o direito à imunidade de que trata o artigo 195, § $7^{\circ}$, da Carta Federal e, consequentemente, desconstituir o crédito tributário inscrito na Certidão de Dívida Ativa ${ }^{\circ}$ 32.725284-7 com a extinção da respectiva Execução Fiscal”. ${ }^{438}$

Antes de mencionar seu posicionamento, o Ministro Relator, Marco Aurélio, relembrou a importância do papel político e social que as imunidades tributárias desempenham dentro da ordem jurídica brasileira, na medida em que elas visam a proteger valores políticos, culturais, sociais e morais essenciais. Ademais, mencionou que esta seria a primeira vez que o Supremo Tribunal Federal analisaria, de forma direta, a

aplicações de recursos, bem como da mensuração dos gastos e despesas relacionados com a atividade assistencial, especialmente daqueles necessários à comprovação do disposto no inciso VI do art. $3^{\circ}$, e demonstradas as contribuições previdenciárias devida, como se a entidade não gozasse da isenção."

430، Art. $1^{\circ}$ Considera-se entidade beneficente de assistência social, para fins de concessão do Certificado de Entidade de Fins Filantrópicos, de que trata o art. 55, inciso II, da Lei n ${ }^{\circ} 8.212$, de 24 de julho de 1991, a instituição beneficente de assistência social, educacional ou de saúde, sem fins lucrativos, que atue, precipuamente, no sentido de:

IV - promover, gratuitamente, assistência educacional ou de saúde."

431 "Art. $2^{\circ}$ Faz jus ao Certificado de Entidade de Fins Filantrópicos a entidade beneficente de assistência social que demonstre, cumulativamente:

IV - aplicar anualmente pelo menos vinte por cento da receita bruta proveniente da venda de serviços e de bens não integrantes do ativo imobilizado, bem como das contribuições operacionais, em gratuidade, cujo montante nunca será inferior à isenção de contribuições previdenciárias usufruída;"

432 " $1^{\circ} \mathrm{O}$ Certificado de Entidade de Fins Filantrópicos somente será fornecido à entidade cuja prestação de serviços gratuitos seja atividade permanente e sem discriminação de qualquer natureza."

433 " $3^{\circ} \mathrm{A}$ entidade da área de saúde cujo percentual de atendimentos decorrentes de convênio firmado com o Sistema Único de Saúde (SUS) seja, em média, igual ou superior a sessenta por cento do total realizado nos três últimos exercícios, fica dispensada na observância a que se refere o inciso IV deste artigo."

${ }^{434}$ Idem à ADI n. 2.621.

435 "II - seja portadora do Certificado e do Registro de Entidade de Fins Filantrópicos, fornecido pelo Conselho Nacional de Assistência Social, renovado a cada três anos"

436 "III - fixar normas para a concessão de registro e certificado de fins filantrópicos às entidades privadas prestadoras de serviços e assessoramento de assistência social;"

437 "IV - conceder atestado de registro e certificado de entidades de fins filantrópicos, na forma do regulamento a ser fixado, observado o disposto no art. $9^{\circ}$ desta lei;"

${ }^{438}$ Trecho obtido do voto do Ministro Marco Aurélio, o qual fora extraído após o autor deste trabalho científico ter assistido, em 29 de outubro de 2014, o julgamento do RE 566.622 no youtube (www.youtube.com). 
constitucionalidade do artigo 55 da Lei no 8.212/1991, já que das outras vezes só houve uma apreciação marginal do assunto. O Ministro Relator citou vários exemplos e o mais recente deles foi o RE $n^{\circ}$ 636.941, de Relatoria do Ministro Luiz Fux, no qual discutiu-se se a Contribuição ao PIS encaixaria-se na regra imunitória do artigo $195, \S 7^{\circ}$ da Carta Política de 1988.

Nessa oportunidade, de acordo com as palavras do Ministro Marco Aurélio,

o Tribunal, sob o ângulo da repercussão geral, enfrentou tema similar, porém mais restrito, já que no Recurso interposto pela União não se arguiu a inconstitucionalidade formal do artigo 55 da Lei $\mathrm{n}^{\circ}$ 8.212/1991, mas tão somente se a norma (artigo 195, $\S 7^{\circ}$ ) alcançaria a Contribuição ao PIS.

Prosseguindo em seu voto, o Ministro Marco Aurélio mencionou que a questão da necessidade de edição de lei complementar ou lei ordinária para tratar dos requisitos a serem observados pelas entidades beneficentes de assistência social deve ser interpretada tendo como base a combinação dos elementos teleológicos e sistemáticos dos artigos 146, inciso II e 195, § $7^{\circ}$, ambos da Constituição Federal de 1988.

De acordo com seu entendimento, por tratar-se de "limitação constitucional ao poder de tributar", as imunidades condicionadas devem ser regulamentadas via Lei Complementar, o que enseja a interpretação conjunta dos artigos 146, inciso II e 195, § $7^{\circ}$, da Constituição Federal de 1988. E, em razão de, atualmente, a única Lei Complementar que regula os requisitos a serem preenchidos pelas entidades imunes ser o artigo 14 do Código Tributário Nacional, os requisitos a serem preenchidos pelas entidades beneficentes de assistência social são, única e exclusivamente, os contido nesse dispositivo legal.

De acordo com suas palavras,

o Tribunal deve seguir a linha hermenêutica utilizada quanto às outras espécies de imunidade e compreender a cláusula de reserva legal tendo em conta a unidade da Constituição e as funções políticas e sociais próprias da imunidade ora discutida. $\mathrm{O}$ Tribunal deve manter a mesma interpretação sistemática e teleológica.

Com essa fundamentação, o Ministro Marco Aurélio votou no sentido de dar provimento ao Recurso Extraordinário interposto pela Sociedade Beneficente de Parobé, para o fim de detemrinar a desconstituição do crédito tributário exigido pela União, já que houve o reconhecimento da sua condição de entidade imune às contribuições sociais destinadas à seguridade social. 
O Ministro Joaquim Barbosa, Relator das ADIN $n^{\text {os }} 2.028,2036,2.621$ e 2.228, acompanhou o voto do Relator do $\mathrm{RE} \mathrm{n}^{\mathrm{o}} 566.622$ e manteve as liminares (cautelares) concedidas nos autos das Ações Diretas de Inconstitucionalidades mencionadas acima.

Os próximos Ministros a votarem, a Ministra Cármen Lúcia e o Ministro Roberto Barroso, acompanharam os votos do Ministro Marco Aurélio, no tocante ao RE no 566.622, e o do Ministro Joaquim Barbosa, no que diz respeito às ADINs n ${ }^{\text {os }} 2.028,2036,2.621$ e 2.228.

O Ministro Teori Zavascki, próximo integrante do Supremo Tribunal Federal a votar, pediu vistas dos autos. Para tanto, justificou seu pedido alicerçado em dois argumentos: primeiro, o de que teria de analisar os feitos com mais profundidade, pois, aos seus olhos, pretender-se-ia alterar a jurisprudência consolidada no seio do STF de que o artigo 55 da Lei n. 8.212/1991 é o instrumento hábil e apto para estabelecer as condições a serem observadas pelas entidades beneficentes de assistência social no gozo da imunidade às contribuições sociais destinadas à seguridade social; e segundo, o de que, na hipótese de ser dado provimento ao Recurso Extraordinário interposto pela Sociedade Beneficente de Parobé, restavam dúvidas acerca do dispositivo legal a ser aplicado, uma vez que o artigo 14 do CTN, por tratar dos pressupostos a serem observados para fins de fruição da imunidade aos impostos, em tese, não seria aplicável às contribuições sociais destinadas à seguridade social, já que são espécies tributárias distintas.

Desde a suspensão do julgamento do RE $\mathrm{n}^{\mathrm{o}} 566.622$ e das ADIs $\mathrm{n}^{\text {os }} 2.028,2.036$, 2.621 e 2.228 , que se deu no dia 4 de junho de 2014, não houve qualquer movimentação processual desses feitos.

Em virtude do pedido de vista formulado pelo Ministro Teori Zavascki, as entidades beneficentes de assistência social e a comunidade como um todo terão de aguardar o prosseguimento desses feitos, a fim de que, finalmente, possa-se ter uma definição acerca da constitucionalidade ou não do artigo 55 Lei no 8.212/1991.

O que se espera com esse julgamento é que, no que diz respeito aos requisitos a serem preenchidos para fins de fruição das imunidades condicionadas aos impostos, o Supremo Tribunal Federal acolha o posicionamento unânime da doutrina e da própria Corte. Além disso, espera-se que o STF declare a inconstitucionalidade do artigo 55 da referida Lei $\mathrm{n}^{\circ}$ 8.212/1991 e reconheça que, atualmente, os únicos requisitos para a fruição das imunidades às contribuições sociais destinadas à seguridade social estão contidos no artigo 14 do Código Tributário Nacional, o qual, por ter sido erigido à condição de Lei Complementar, é o único instrumento hábil a dispor acerca desses pressupostos. 
6.5. "Novos" requisitos a serem preenchidos pelas entidades beneficentes de assistência social, para fins de fruição do gozo da imunidade tributária às contribuições sociais destinadas à seguridade social - o artigo 29, da Lei $\mathbf{n}^{\circ}$ 12.101/2009

Em 27 de novembro de 2009, foi editada a Lei n ${ }^{\circ} 12.101$, que

\begin{abstract}
dispõe sobre a certificação das entidades beneficentes de assistência social, regula os procedimentos de 'isenção' de contribuições para a seguridade social; altera a Lei n. 8.742, de 7 de dezembro de 1993; revoga dispositivos das Leis ns. 8.212, de 24 de julho de 1991, 9.429, de 26 de dezembro de 1993; 9.732, de 11 de dezembro de 1998, 10.684, de 30 de maio de 2003, e da Medida Provisória n. 2.187-13, de 24 de agosto de 2001; e dá outras providências.
\end{abstract}

Em um de seus artigos, mais precisamente o seu artigo $44^{439}$, restou revogado o artigo 55 da Lei $\mathrm{n}^{\text {o }}$ 8.212/1991 que, tal qual visto acima, estabelecia os requisitos a serem preenchidos pelas entidades beneficentes de assistência social, para fins de gozo da imunidade tributária às contribuições sociais destinadas à seguridade social.

Desta forma, em tese, a partir da promulgação da Lei $n^{0} 12.101 / 2009$, os requisitos para fins de gozo da imunidade tributária às contribuições sociais destinadas à seguridade social são os dispostos no artigo 29 dessa lei, que assim determina:

Art. 29. ${ }^{\circ}$ A entidade beneficente certificada na forma do Capítulo II fará jus à isenção do pagamento das contribuições de que tratam os arts. 22 e 23 da Lei $\mathrm{n}^{\circ}$ 8.212, de 24 de julho de 1991, desde que atenda, cumulativamente, aos seguintes requisitos:

I - não percebam, seus dirigentes estatutários, conselheiros, sócios, instituidores ou benfeitores, remuneração, vantagens ou benefícios, direta ou indiretamente, por qualquer forma ou título, em razão das competências, funções ou atividades que lhes sejam atribuídas pelos respectivos atos constitutivos; (Redação dada pela Lei ${ }^{\circ} 12.868$, de 2013)

II - aplique suas rendas, seus recursos e eventual superávit integralmente no território nacional, na manutenção e desenvolvimento de seus objetivos institucionais;

III - apresente certidão negativa ou certidão positiva com efeito de negativa de débitos relativos aos tributos administrados pela Secretaria da Receita Federal do Brasil e certificado de regularidade do Fundo de Garantia do Tempo de Serviço - FGTS;

IV - mantenha escrituração contábil regular que registre as receitas e despesas, bem como a aplicação em gratuidade de forma segregada, em consonância com as normas emanadas do Conselho Federal de Contabilidade;

\footnotetext{
439 "Art. 44. Revogam-se:

I - o art. 55 da Lei n $^{\circ} 8.212$, de 24 de julho de 1991;”
} 
V - não distribua resultados, dividendos, bonificações, participações ou parcelas do seu patrimônio, sob qualquer forma ou pretexto;

VI - conserve em boa ordem, pelo prazo de 10 (dez) anos, contado da data da emissão, os documentos que comprovem a origem e a aplicação de seus recursos e os relativos a atos ou operações realizados que impliquem modificação da situação patrimonial;

VII - cumpra as obrigações acessórias estabelecidas na legislação tributária; VIII - apresente as demonstrações contábeis e financeiras devidamente auditadas por auditor independente legalmente habilitado nos Conselhos Regionais de Contabilidade quando a receita bruta anual auferida for superior ao limite fixado pela Lei Complementar $n^{\circ} 123$, de 14 de dezembro de 2006.

$\S 1^{\circ}$ A exigência a que se refere o inciso I do caput não impede: (Incluído pela Lei $n^{\circ} 12.868$, de 2013)

I - a remuneração aos diretores não estatutários que tenham vínculo empregatício; (Incluído pela Lei $\mathrm{n}^{\circ} 12.868$, de 2013)

II - a remuneração aos dirigentes estatutários, desde que recebam remuneração inferior, em seu valor bruto, a $70 \%$ (setenta por cento) do limite estabelecido para a remuneração de servidores do Poder Executivo federal. (Incluído pela Lei no 12.868 , de 2013)

$\S 2^{\circ}$ A remuneração dos dirigentes estatutários referidos no inciso II do $\S 1^{\circ}$ deverá obedecer às seguintes condições: (Incluído pela Lei $\mathrm{n}^{\circ} 12.868$, de 2013)

I - nenhum dirigente remunerado poderá ser cônjuge ou parente até $3^{\circ}$ (terceiro) grau, inclusive afim, de instituidores, sócios, diretores, conselheiros, benfeitores ou equivalentes da instituição de que trata o caput deste artigo; e (Incluído pela Lei $n^{\circ} 12.868$, de 2013)

II - o total pago a título de remuneração para dirigentes, pelo exercício das atribuições estatutárias, deve ser inferior a 5 (cinco) vezes o valor correspondente ao limite individual estabelecido neste parágrafo. (Incluído pela Lei ${ }^{\circ} 12.868$, de 2013)

$\S 3^{\circ} \mathrm{O}$ disposto nos $\S \S 1^{\circ}$ e $2^{\circ}$ não impede a remuneração da pessoa do dirigente estatutário ou diretor que, cumulativamente, tenha vínculo estatutário e empregatício, exceto se houver incompatibilidade de jornadas de trabalho. (Incluído pela Lei $\mathrm{n}^{\circ} 12.868$, de 2013)

De acordo com o artigo acima transcrito, as entidades beneficentes de assistência social somente farão jus à imunidade às contribuições sociais destinadas à seguridade social se preencherem, cumulativamente, os seguintes requisitos:

1. não remunerar ou conceder qualquer espécie de benefício, em virtude dos serviços prestados à entidade imune, a seus dirigentes estatutários, conselheiros, sócios instituidores ou benfeitores;

2. aplicar suas receitas e superávit integralmente em território nacional, na manutenção e desenvolvimento de seus objetivos sociais;

3. apresentar certidão negativa ou positiva com efeito de negativa relacionada aos tributos administrados e arrecadados pela Receita Federal do Brasil, bem como de certificado de regularidade quanto ao FGTS; 
4. manter escrituração contábil regular, bem como escriturar, de forma segregada, as receitas e despesas concernentes aos serviços gratuitos prestados;

5. não distribuir resultados, dividendos, bonificações, participações ou parcela de seu patrimônio, a qualquer título;

6. manter, pelo prazo de dez anos, os documentos contábeis e fiscais que comprovem a origem e a aplicação de seus recursos e os relativos aos atos ou operações realizados que impliquem modificação da situação patrimonial da entidade;

7. cumprir com seus deveres instrumentais tributários; e

8. apresentar as demonstrações contábeis e financeiras devidamente auditadas por auditor independente e legalmente habilitado nos Conselhos Regionais de Contabilidade quando a receita bruta anual auferida for superior ao limite fixado pela Lei Complementar $n^{\circ} 123$, de dezembro de $2006^{440}$.

Da mais simples e singela análise dos supostos a serem preenchidos pelas entidades beneficentes de assistência social para fins de fruição da imunidade tributária às contribuições sociais destinadas à seguridade social, verifica-se que o referido artigo 29 é mais abrangente do que o Código Tributário Nacional.

A fim de facilitar a visualização desse alargamento dos pressupostos exigidos pela Lei $n^{\circ} 12.101$, de 2009, elaboramos o seguinte quadro comparativo:

\begin{tabular}{|c|c|}
\hline Lei no 12.101 & Código Tributário Nacional \\
\hline $\begin{array}{l}\text { I - não percebam, seus dirigentes } \\
\text { estatutários, conselheiros, sócios, instituidores ou } \\
\text { benfeitores, remuneração, vantagens ou benefícios, } \\
\text { direta ou indiretamente, por qualquer forma ou título, } \\
\text { em razão das competências, funções ou atividades que } \\
\text { lhes sejam atribuídas pelos respectivos atos } \\
\text { constitutivos; (Redação dada pela Lei n }{ }^{\circ} 12.868 \text {, de } \\
\text { 2013); } \\
\text { V - não distribua resultados, dividendos, } \\
\text { bonificações, participações ou parcelas do seu } \\
\text { patrimônio, sob qualquer forma ou pretexto; }\end{array}$ & $\begin{array}{l}\text { I - não distribuírem qualquer parcela de seu } \\
\text { patrimônio ou de suas rendas, a qualquer título; } \\
\text { (Redação dada pela } \operatorname{Lcp} \mathrm{n}^{\circ} \text { 104, de } 2001 \text { ) }\end{array}$ \\
\hline
\end{tabular}

\footnotetext{
${ }^{440}$ A Lei Complementar $n^{\circ} 123$ instituiu o Estatuto Nacional da Microempresa e da Empresa de Pequeno Porte, dentre outras providências. De acordo com o artigo $3^{\circ}$, inciso II dessa Lei Complementar, o limite máximo fixado por essa norma complementar é de $\mathrm{R} \$ 3.600 .000,00$.
} 


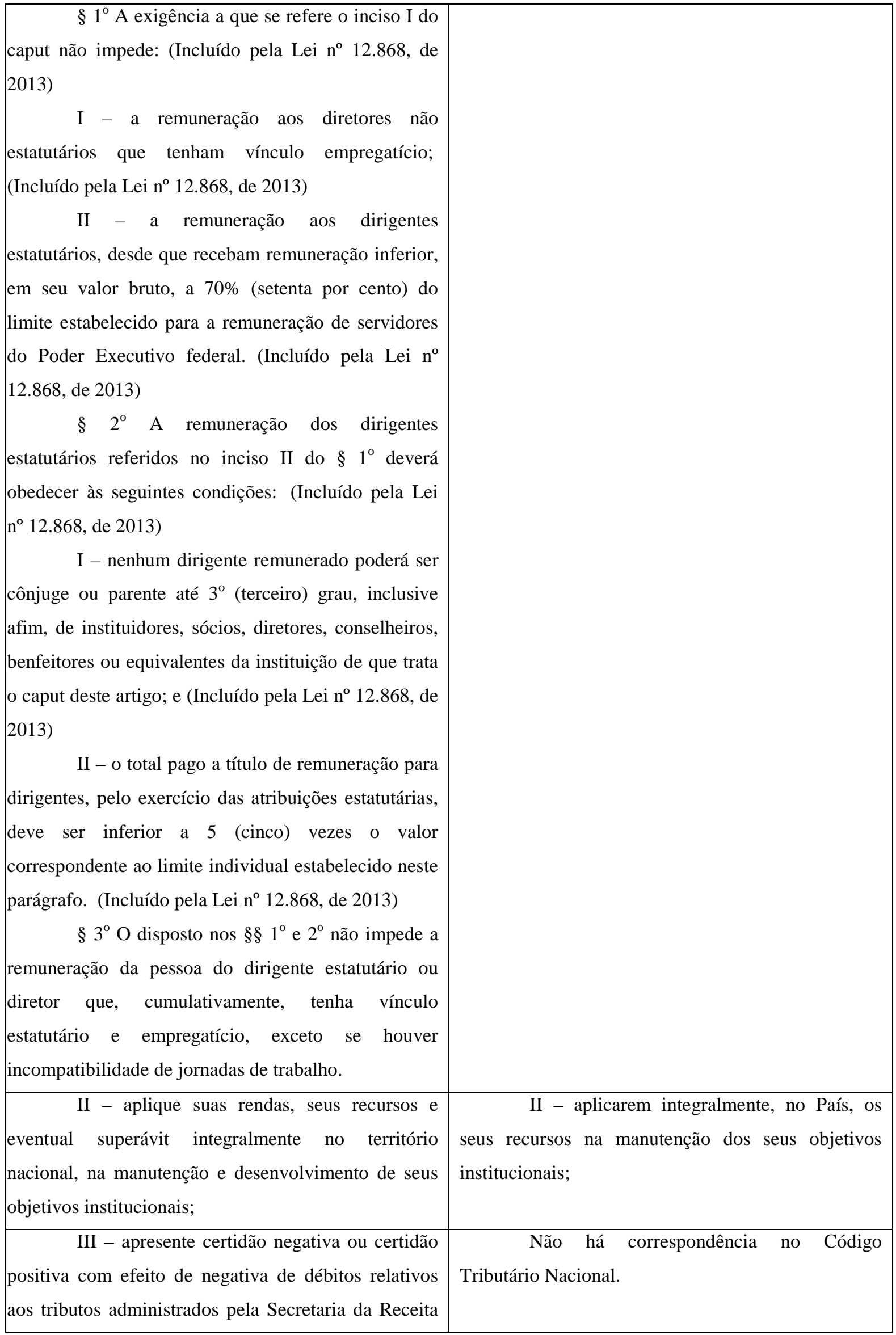




\begin{tabular}{|c|c|}
\hline $\begin{array}{l}\text { Federal do Brasil e certificado de regularidade do } \\
\text { Fundo de Garantia do Tempo de Serviço - FGTS; }\end{array}$ & \\
\hline $\begin{array}{l}\text { IV - mantenha escrituração contábil regular } \\
\text { que registre as receitas e despesas, bem como a } \\
\text { aplicação em gratuidade de forma segregada, em } \\
\text { consonância com as normas emanadas do Conselho } \\
\text { Federal de Contabilidade; } \\
\text { VI - conserve em boa ordem, pelo prazo de } \\
\text { 10 (dez) anos, contado da data da emissão, os } \\
\text { documentos que comprovem a origem e a aplicação } \\
\text { de seus recursos e os relativos a atos ou operações } \\
\text { realizados que impliquem modificação da situação } \\
\text { patrimonial; } \\
\text { VII - cumpra as obrigações acessórias } \\
\text { estabelecidas na legislação tributária; } \\
\text { VIII - apresente as demonstrações contábeis } \\
\text { e financeiras devidamente auditadas por auditor } \\
\text { independente legalmente habilitado nos Conselhos } \\
\text { anual auferida for superior ao limite fixado pela Lei } \\
\text { Complementar no } 123 \text {, de } 14 \text { de dezembro de } 2006 \text {. }\end{array}$ & $\begin{array}{l}\text { III - manterem escrituração de suas receitas } \\
\text { e despesas em livros revestidos de formalidades } \\
\text { capazes de assegurar sua exatidão. }\end{array}$ \\
\hline
\end{tabular}

Pela análise da tabela acima, constata-se que todas as exigências contidas no artigo 14 do Código Tributário Nacional estão retratadas no artigo 29 da Lei $\mathrm{n}^{\circ}$ 12.101. Contudo, a recíproca não é verdadeira, de modo que os requisitos conflitantes não poderão ser exigidos, posto que a lei complementar existente para traçar as condições de gozo da imunidade tributária às contribuições sociais destinadas à seguridade social a eles não faz referência.

No que se refere à questão da remuneração dos dirigentes, conselheiros, sócios instituidores ou benfeitores, consoante visto acima, a única ressalva feita diz respeito à impossibilidade de seus vencimentos superarem os valores pagos pela média de mercado. Assim, se determinado dirigente, estatutário ou não, perceber remuneração compatível com a paga pelo mercado, tal fato não poderá ensejar a suspensão da imunidade tributária às contribuições sociais destinadas à seguridade social, diferentemente do que dispõe o artigo 29 da Lei $n^{\circ} 12.101$, já que não se estará a distribuir qualquer parcela do patrimônio da entidade imune. 
Outro ponto dessa Lei que não se coaduna com o artigo 14 do Código Tributário Nacional corresponde à exigência da apresentação de certidões, negativas ou positivas, com efeitos de negativa.

De acordo como o inciso III do artigo 29 da Lei n ${ }^{\circ} 12.101$, as entidades beneficentes de assistência social deverão demonstrar sua regularidade fiscal, sob pena de não fruição da imunidade do artigo 195, § $7^{\circ}$, da Constituição Federal.

O Código Tributário Nacional, especialmente seu artigo 14, em momento algum condiciona a fruição da imunidade à apresentação de certidão de regularidade fiscal por parte do ente imune, de modo que essa exigência, por não possuir arrimo constitucional, não pode ensejar no não reconhecimento da condição de entidade imune da instituição beneficente de assistência social.

O mesmo se dá em relação aos requisitos que tratam da escrituração dos livros e registros das entidades imunes. Muito embora os incisos IV, VI e VIII tratem da necessidade de escrituração dos livros contábeis e fiscais, tais exigência extrapolam o contido no artigo 14 do Código Tributário Nacional, já que estabelecem minúcias que dificultam e desistimulam o preenchimento dos requisitos à fruição da imunidade tributária.

Apesar da patente inconstitucionalidade do artigo 29 da Lei $\mathrm{n}^{\circ} 12.101$, e do maciço entendimento doutrinário ${ }^{441}$ de que os requisitos para fins de gozo da imunidade tributária às contribuições sociais destinadas à seguridade social só podem ser veiculados mediante lei complementar, nossos Tribunais têm julgado constitucional o referido artigo 29.

Como exemplo, podemos citar a recente decisão proferida pelos integrantes da Sexta Turma do Egrégio Tribunal Regional Federal da Terceira Região, para quem somente valerá a fruição dessa espécie de imunidade na hipótese de os pressupostos do artigo 29 da Lei $n^{\circ}$ 12.101 serem preenchidos pela entidade imune:

\footnotetext{
${ }^{441}$ Luís Eduardo Schoueri menciona em sua obra "Direito Tributário" que, não obstante o artigo 55, da Lei ${ }^{\circ}$ 8.212/1991 ter sido revogado, tal celeuma não perdeu sua atualidade nem deixou de existir em nosso ordenamento, pois foi editada a Lei $\mathrm{n}^{\mathrm{o}} 12.101 / 2009$, a qual estabelece inúmeros requisitos a serem preenchidos pelas entidades beneficentes de assistência social para fruição da imunidade tributária às contribuições sociais: "Deve-se aplicar a esse caso o que se viu acima, no sentido de que a lei que pode apresentar tais requisitos é uma lei complementar, não uma lei ordinária, já que, afinal, a imunidade é uma limitação constitucional ao poder de tributar (art. 146, II). Não obstante, a Lei 8.212/91, tratando da organização da seguridade social e do plano de custeio desta, arrola, no seu art. 55, uma série de condições para o gozo da 'isenção'. A referida lei, por ser ordinária, não poderia impor requisitos diversos dos previstos no Código Tributário Nacional, que é lei complementar. O dispositivo foi revogado, mas o tema não perde atualidade. Nesse sentido, a Lei 12.101, de 2009 voltou a arrolar uma série de requisitos para o gozo da imunidade, que ultrapassam os previstos pelo Código Tributário Nacional. Independentemente da razoabilidade, ou não, daquele dispositivo, importa ver que a lei ordinária não é instrumento adequado para regulamentar uma imunidade conferida constitucionalmente" (SCHOUERI, Luís Eduardo. Direito tributário. São Paulo: Saraiva, 2011. p. 401-402).
} 
EMBARGOS DE DECLARAÇÃO. LEI No 12.101/09. CERTIFICAÇÃO DE ENTIDADES BENEFICENTES. REQUISITOS PARA A IMUNIDADE. FALTA DE DOCUMENTAÇÃO QUE OS COMPROVE. EMBARGOS REJEITADOS.

1. Não há omissão no julgado com relação à análise da Lei $\mathrm{n}^{\circ} 12.101 / 2009$, tendo a douta relatora afirmado expressamente que esta Lei "passou a dispor sobre a certificação das entidades beneficentes de assistência social e a regular os procedimentos de isenção de contribuições para a seguridade social". O voto aponta, inclusive, para o artigo 29 do diploma legal, especificamente.

2. A Turma concluiu que não há, nos autos, documentos que comprovem atender o contribuinte aos requisitos do art. 29 da Lei $n^{\circ}$ 12.101/09. Não faz jus, portanto, à imunidade invocada, na importação dos produtos mencionados na inicial.

3. Ainda que os embargos de declaração tenham como propósito o prequestionamento da matéria, faz-se imprescindível, para o acolhimento do recurso, que se constate a existência de qualquer dos vícios previstos no art. 535 do Código de Processo Civil, sem o que se torna inviável seu acolhimento. Nesse sentido, a título ilustrativo, consulte-se o seguinte precedente: EDcl nos EDcl no REsp 1107543/SP, Rel. Ministro NAPOLEÃO NUNES MAIA FILHO, Primeira Seção, julgado em 26/10/2011, DJe 18/11/2011.

4. Embargos de declaração rejeitados. ${ }^{, 42-443}$

Com o intuito de contestar judicialmente a amplitude dos requisitos a serem preenchidos por parte das entidades beneficentes de assistência social, no que concerne à imunidade às contribuições sociais destinadas à seguridade social, a Confederação Nacional dos Estabelecimentos de Ensino (CONFENEN) ingressou, em 27 de outubro de 2010, com a Ação Direta de Inconstitucionalidade $n^{\circ} 4480$, questionando não só o artigo 29 da Lei $n^{\circ}$ 12.101, mas também os artigos $1^{\mathrm{o} 444}, 13$ (com seus parágrafos e incisos) ${ }^{445}, 14, \S \S 1^{\mathrm{o} 446} \mathrm{e}$

\footnotetext{
${ }^{442}$ AMS no 00072435720104036100, TRF da $3^{\text {a }}$ Região, $6^{\text {a }}$ Turma, Rel. Des. Fed. Nelton dos Santos, DJ-e de 16.05.2014. Disponível em: <www.trf3.jus.br〉. Acesso em: 06 nov. 2014.

${ }^{443}$ Em idêntico sentido: APELREEX no 00348238819994039999 , TRF da $3^{\text {a }}$ Região, $5^{\text {a }}$ Turma, Rel. Des. Fed. André Nekatschalow, DJ-e de 15.05.2013. Disponível em: <www.cjf.jus.br〉. Acesso em: 06 nov. 2014; AC n ${ }^{\circ}$ 00030497120104058100, TRF da 5a Região, $3^{\mathrm{a}}$ Turma, Rel. Des. Fed. Geraldo Apoliano, DJ-e de 06.03.2013. Disponível em: <www.cjf.jus.br〉. Acesso em: 06 nov. 2014; AI no 00324555220074030000, TRF da $3^{\text {a }}$ Região, $1^{a}$ Turma, Rel(a). Juíza Conv. Silvia Rocha, DJ-e de 13.07.2011. Disponível em: <www.cjf.jus.br>. Acesso em: 06 nov. 2014.

444 "Art. 1ํㅡㄹ A certificação das entidades beneficentes de assistência social e a isenção de contribuições para a seguridade social serão concedidas às pessoas jurídicas de direito privado, sem fins lucrativos, reconhecidas como entidades beneficentes de assistência social com a finalidade de prestação de serviços nas áreas de assistência social, saúde ou educação, e que atendam ao disposto nesta Lei."
}

445 “Art. 13. Para fins de concessão ou renovação da certificação, a entidade de educação que atua nas diferentes etapas e modalidades da educação básica, regular e presencial, deverá: (Redação dada pela Lei $\mathrm{n}^{\circ} 12.868$, de 2013)

I - demonstrar sua adequação às diretrizes e metas estabelecidas no Plano Nacional de Educação (PNE), na forma do art. 214 da Constituição Federal; (Incluído pela Lei n 12.868, de 2013) 
$2^{\text {o447 }}, 18^{448}, \S \S 1^{\mathrm{o} 449}, 2^{\mathrm{o} 450}$ e $3^{\mathrm{o} 451}, 31^{452}$ e $32, \S 1^{0^{453}}$. Tal ADI foi distribuída ao Ministro

Gilmar Mendes.

II - atender a padrões mínimos de qualidade, aferidos pelos processos de avaliação conduzidos pelo Ministério da Educação; e (Incluído pela Lei no 12.868, de 2013)

III - conceder anualmente bolsas de estudo na proporção de 1 (uma) bolsa de estudo integral para cada 5 (cinco) alunos pagantes. (Incluído pela Lei n ${ }^{\circ} 12.868$, de 2013)

$\S 1^{\circ}$ Para o cumprimento da proporção descrita no inciso III do caput, a entidade poderá oferecer bolsas de estudo parciais, observadas as seguintes condições: (Redação dada pela Lei $\mathrm{n}^{\circ} 12.868$, de 2013)

I - no mínimo, 1 (uma) bolsa de estudo integral para cada 9 (nove) alunos pagantes; e (Redação dada pela Lei no 12.868 , de 2013)

II - bolsas de estudo parciais de 50\% (cinquenta por cento), quando necessário para o alcance do número mínimo exigido, conforme definido em regulamento; (Redação dada pela Lei $n^{\circ} 12.868$, de 2013)

III - (revogado); (Redação dada pela Lei no 12.868 , de 2013)

a) (revogada); (Redação dada pela Lei $\mathrm{n}^{\circ} 12.868$, de 2013)

b) (revogada). (Redação dada pela Lei no 12.868 , de 2013)

$\S 2^{\circ}$ Será facultado à entidade substituir até $25 \%$ (vinte e cinco por cento) da quantidade das bolsas de estudo definidas no inciso III do caput e no $\S 1^{\circ}$ por benefícios complementares, concedidos aos alunos matriculados cuja renda familiar mensal per capita não exceda o valor de 1 (um) salário-mínimo e meio, como transporte, uniforme, material didático, moradia, alimentação e outros benefícios definidos em regulamento. (Redação dada pela Lei ${ }^{\circ} 12.868$, de 2013)

$\S 3^{\circ}$ Admite-se o cumprimento do percentual disposto no $\S 2^{\circ}$ com projetos e atividades para a garantia da educação em tempo integral para alunos matriculados na educação básica em escolas públicas, desde que em articulação com as respectivas instituições públicas de ensino, na forma definida pelo Ministério da Educação. (Redação dada pela Lei n ${ }^{\circ} 12.868$, de 2013)

$\S 4^{\circ}$ Para fins do cumprimento da proporção de que trata o inciso III do caput: (Redação dada pela Lei ${ }^{\circ} 12.868$, de 2013)

I - cada bolsa de estudo integral concedida a aluno com deficiência, assim declarado ao Censo da Educação Básica, equivalerá a 1,2 (um inteiro e dois décimos) do valor da bolsa de estudo integral; e (Redação dada pela Lei $\mathrm{n}^{\circ} 12.868$, de 2013)

II - cada bolsa de estudo integral concedida a aluno matriculado na educação básica em tempo integral equivalerá a 1,4 (um inteiro e quatro décimos) do valor da bolsa de estudo integral; (Redação dada pela Lei ${ }^{\circ}$ 12.868 , de 2013)

III - (revogado). (Redação dada pela Lei no 12.868 , de 2013)

$\S 5^{\circ}$ As equivalências previstas nos incisos I e II do $\S 4^{\circ}$ não poderão ser cumulativas. (Redação dada pela Lei ${ }^{\circ}$ 12.868 , de 2013)

$\S 6^{\circ}$ Considera-se, para fins do disposto nos $\S \S 3^{\circ}$ e $4^{\circ}$, educação básica em tempo integral a jornada escolar com duração igual ou superior a 7 (sete) horas diárias, durante todo o período letivo, e compreende tanto o tempo em que o aluno permanece na escola como aquele em que exerce atividades escolares em outros espaços educacionais, conforme definido pelo Ministério da Educação. (Redação dada pela Lei $n^{\circ} 12.868$, de 2013)

$\S 7^{\circ}$ As entidades de educação que prestam serviços integralmente gratuitos deverão garantir a observância da proporção de, no mínimo, 1 (um) aluno cuja renda familiar mensal per capita não exceda o valor de um saláriomínimo e meio para cada 5 (cinco) alunos matriculados. (Incluído pela Lei n ${ }^{\circ} 12.868$, de 2013)”.

446 "§ $1^{\circ}$ A bolsa de estudo integral será concedida a aluno cuja renda familiar mensal per capita não exceda o valor de 1 1/2 (um e meio) salário mínimo."

447 "§ $2^{-}$A bolsa de estudo parcial será concedida a aluno cuja renda familiar mensal per capita não exceda o valor de 3 (três) salários mínimos."

448 “Art. 18. A certificação ou sua renovação será concedida à entidade de assistência social que presta serviços ou realiza ações socioassistenciais, de forma gratuita, continuada e planejada, para os usuários e para quem deles necessitar, sem discriminação, observada a Lei ${ }^{\circ}$ 8.742, de 7 de dezembro de 1993. (Redação dada pela Lei ${ }^{\circ}$ 12.868, de 2013)."

$449 \S 1^{\circ}$ Consideram-se entidades de assistência social aquelas que prestam, sem fins lucrativos, atendimento e assessoramento aos beneficiários abrangidos pela Lei $\mathrm{n}^{\circ} 8.742$, de 7 de dezembro de 1993 , e as que atuam na defesa e garantia de seus direitos. (Redação dada pela Lei n 12.868 , de 2013)." 
Em sede de liminar, a CONFENEN requereu a suspensão,

[...] por inconstitucionalidade, até a decisão final da ação, a eficácia dos dispositivos já apontados da Lei Federal n. 12.101, de 27 de novembro de 2009, publicada no Diário Oficial da União de 30 de novembro de 2009, ante a manifesta presença dos requisitos do "fumus boni iuris" e do iminente dano de difícil e incerta reparação do "periculum in mora", nos moldes do artigo 10 da Lei n. 9.688.

Até o presente momento, não houve qualquer análise do pedido de concessão de liminar formulado pela COFENEN. O último andamento do processo diz respeito ao pedido de aditamento da Inicial apresentada por essa confederação, haja vista a alteração sofrida pelos artigos 13, 18 e 29 da Lei $n^{\circ} 12.101$, de 2009, por conta da edição da Lei $n^{\circ} 12.868$, de 2013.

Dessa forma, tendo em vista que o Supremo Tribunal Federal ainda não apreciou essa questão, verifica-se que as únicas manifestações judiciais acerca da aplicação do artigo 29 às entidades beneficentes de assistência social estão restritas às instâncias inferiores.

No entanto, espera-se que o Supremo Tribunal Federal venha a adotar nessa ADIN o mesmo entendimento que vem sendo desenhado no julgamento do RE $\mathrm{n}^{\circ} 566.622$ e ADIs $\mathrm{n}^{\text {os }}$ 2.028, 2.036, 2.621 e 2.228, o qual, após apresentar o placar parcial favorável aos

450 “ $\$ 2^{\circ}$ Observado o disposto no caput e no $\S 1^{\circ}$, também são consideradas entidades de assistência social: (Redação dada pela Lei no 12.868 , de 2013)

I - as que prestam serviços ou ações socioassistenciais, sem qualquer exigência de contraprestação dos usuários, com o objetivo de habilitação e reabilitação da pessoa com deficiência e de promoção da sua inclusão à vida comunitária, no enfrentamento dos limites existentes para as pessoas com deficiência, de forma articulada ou não com ações educacionais ou de saúde; (Incluído pela Lei no 12.868, de 2013)

II - as de que trata o inciso II do art. 430 da Consolidação das Leis do Trabalho (CLT), aprovada pelo DecretoLei $\mathrm{n}^{\circ} 5.452$, de $1^{\circ}$ de maio de 1943 , desde que os programas de aprendizagem de adolescentes, de jovens ou de pessoas com deficiência sejam prestados com a finalidade de promover a integração ao mercado de trabalho, nos termos da Lei $n^{\circ} 8.742$, de 7 de dezembro de 1993, observadas as ações protetivas previstas na Lei $n^{\circ} 8.069$, de 13 de julho de 1990; e (Incluído pela Lei no 12.868, de 2013)

III - as que realizam serviço de acolhimento institucional provisório de pessoas e de seus acompanhantes, que estejam em trânsito e sem condições de autossustento, durante o tratamento de doenças graves fora da localidade de residência, observada a Lei no 8.742, de 7 de dezembro de 1993. (Incluído pela Lei n 12.868, de 2013)"

451 " $\S 3^{\circ}$ Desde que observado o disposto no caput e no $\S 1^{\circ}$ deste artigo e no art. 19, exceto a exigência de gratuidade, as entidades referidas no art. 35 da Lei $\mathrm{n}^{\circ} 10.741$, de $1^{\circ}$ de outubro de 2003, poderão ser certificadas, com a condição de que eventual cobrança de participação do idoso no custeio da entidade se dê nos termos e limites do $\S 2^{\circ}$ do art. 35 da Lei $n^{\circ} 10.741$, de $1^{\circ}$ de outubro de 2003. (Redação dada pela Lei $n^{\circ} 12.868$, de 2013)"

452 “Art. 31. O direito à isenção das contribuições sociais poderá ser exercido pela entidade a contar da data da publicação da concessão de sua certificação, desde que atendido o disposto na Seção I deste Capítulo.”

453 “§ $1^{\circ}$ C Considerar-se-á automaticamente suspenso o direito à isenção das contribuições referidas no art. 31 durante o período em que se constatar o descumprimento de requisito na forma deste artigo, devendo o lançamento correspondente ter como termo inicial a data da ocorrência da infração que lhe deu causa." 
contribuintes (voto favorável dos Ministros Marco Aurélio, Joaquim Barbosa, Cármen Lúcia e Roberto Barroso), já que eles entenderam que os lindes das imunidades só podem ser veiculados via lei complementar, foi suspenso por conta do pedido de vista do Ministro Teori Zavascki.

Na hipótese de adotar-se o entendimento de que as imunidades às contribuições sociais destinadas à seguridade social só podem ser reguladas por intermédio de lei complementar, o Supremo Tribunal Federal, além de ir ao encontro do maciço entendimento doutrinário, manterá a coerência sistêmica já manifestada por ele quando do julgamento dos requisitos a serem preenchidos para fins de fruição da imunidade condicionada aos impostos. 


\section{CONCLUSÕES}

Como resultado do estudo sobre a imunidade tributária às contribuições sociais das entidades beneficentes de assistência social, apresentam-se as seguintes conclusões:

1. As imunidades tributárias são normas de estrutura contidas exclusivamente no texto constitucional que, ao expressamente estabelecer as situações, coisas ou pessoas sobre as quais não poderá recair a tributação, auxiliam na demarcação do campo de atuação de cada um dos entes políticos, União, Estados, Distrito Federal e Municípios.

2. Não obstante a Constituição Federal de 1988 mencionar que as "Limitações Constitucionais ao Poder de Tributar" correspondem somente às imunidades tributárias e aos princípios constitucionais tributários contidos nos artigos 150, 151 e 152, entendemos que o próprio Texto Constitucional contempla outras "Limitações Constitucionais ao Poder de Tributar" em outros dispositivos. Como exemplo, podem ser citados o artigo 170, parágrafo único, que trata do princípio do livre exercício das atividades econômicas, e o artigo 195, $\S 7^{\circ}$, que trata da imunidade tributária às contribuições sociais destinadas à seguridade social das entidades beneficentes de assistência social.

Por entendermos que as imunidades tributárias não atuam como limitadoras da competência tributária, mas sim como normas auxiliares ao legislador para forjar a sua competência, acreditamos que a terminologia mais adequada para a Seção II, do Capítulo I, do Título VI, da Constituição Federal de 1988 seria a de "Delimitações Constitucionais à Competência Tributária".

3. Conforme mencionado em tópico específico deste trabalho científico, os traços distintivos entre imunidade, isenção e não incidência são os seguintes:

As regras de imunidade tributária representam normas de estrutura expressamente contidas na Constituição Federal de 1988, que tratam da incompetência da União, dos Estados, do Distrito Federal e Municípios. Ou seja, a Constituição estabelece as pessoas, coisas ou situações sobre as quais os entes tributantes não podem exercer sua competência tributária impositiva.

As regras isentivas, por seu turno, possuem por objetivo suprimir, de forma parcial, um ou mais critérios do antecedente ou do consequente da regra-matriz de incidência tributária.

Enquadram-se no conceito de não incidência as situações, pessoas ou coisas não contempladas pelo legislador como passíveis de serem objeto de tributação. 
As normas que tratam da imunidade devem estar dispostas, necessariamente, no texto constitucional, ao passo que as normas isentivas só podem ser veiculadas via lei, seja ordinária, seja complementar.

Por fim, as regras de imunidade devem ser interpretadas de forma extensiva, enquanto as de isenção de maneira restritiva.

4. As normas jurídicas que encerram as hipóteses de imunidade tributária possuem a feição de limite objetivo, já se que se voltam a realizar valores, de forma indireta ou mediata. Por este motivo, pode-se dizer que o limite objetivo é iluminado pelo valor mas sem com ele se confundir. As imunidades tributárias foram concebidas para resguardar valores considerados como de superior interesse nacional, tais como a manutenção das entidades federadas, o exercício das atividades religiosas, da democracia, das instituições educacionais, assistenciais e beneficentes e o acesso à informação e à cultura.

Tendo em vista que o legislador constituinte original, ao externar seu juízo valorativo, pinçou acontecimentos específicos do mundo fenomênico que não poderiam ser objeto de tributação e os incluiu no texto constitucional, comprovada está a condição de limite objetivo das imunidades tributárias, na medida em que houve a pré-demarcação do campo de atuação estatal, por meio de descrição de comportamentos obrigatórios, permitidos ou proibidos.

5. De acordo com o artigo $60, \S 4^{\circ}$, da Constituição Federal de 1988, a forma federativa de Estado, o voto direito secreto, universal e periódico, a separação dos poderes e os direitos e garantias individuais são considerados cláusulas pétreas, ou seja, não podem ser modificados, nem mesmo por meio de Emenda Constitucional. A única forma de alteração dos itens acima se dá por meio da promulgação de uma nova Constituição.

Em razão de as imunidades tributárias, especialmente as genéricas, terem sido concebidas para preservar valores considerados como de superior interesse nacional, tais como (a) a manutenção das entidades federadas; (b) o exercício das atividades religiosas, democráticas, das instituições educacionais, assistenciais e de filantropia; (c) e o acesso à informação e à cultura, elas representam direitos e garantias individuais que, por possuírem a natureza de cláusulas pétreas, não podem ser alteradas, nem mesmo por intermédio de Emenda Constitucional.

Entretanto, entendemos que as demais regras imunitórias que tratam de simples limitação material e não possuem grande carga valorativa em sua gênese, por não serem consideradas clausulas de imutabilidade, podem ser alteradas normalmente pelo legislador constituinte. 
6. Conforme demonstrado neste trabalho científico, se a entidade imune reverter as receitas auferidas direta ou indiretamente com seus objetivos sociais no seu desiderato hodierno, o primeiro passo para garantir-se a imunidade está dado. Contudo, a instituição deverá, ainda, a fim de evitar a infração ao princípio da livre concorrência e, consequentemente, ver a hipótese imunitória afastada, não praticar nenhum ato que vise a limitar, falsear ou de qualquer forma prejudicar a livre concorrência ou a livre iniciativa; dominar mercado relevante de bens ou serviços; aumentar arbitrariamente seus superávits; ou exercer de forma abusiva posição dominante.

7. A interpretação das normas constitucionais que tratam das imunidades tributárias deve se dar com fulcro nos métodos sistemático (que analisa o sistema como um todo) e teleológico (que leva em consideração a finalidade da norma criada), o que significa dizer que as regras de imunidade devem ser interpretadas de forma ampliativa.

8. A doutrina classifica as imunidades tributárias de diversas formas, levando em consideração diversos critérios. Uma vez que o foco do presente trabalho científico foi a imunidade às contribuições sociais destinadas à seguridade social das entidades beneficentes de assistência social, adotou-se a classificação "imunidades incondicionadas" e "imunidades condicionadas".

Por "imunidade incondicionada", entendeu-se ser aquela que independe de qualquer requisito ou condição disposta em norma infraconstitucional para que a imunidade tenha plena eficácia. Basta enquadrar-se nas hipóteses descritas e contidas no Texto Constitucional para que o direito à fruição da imunidade seja garantido e reconhecido.

Por sua vez, as "imunidades condicionadas" só operam plenamente mediante a observância de certas condições definidas em normas infraconstitucionais.

9. De acordo com o texto constitucional, dois são os requisitos relevantes para a configuração da assistência social: atendimento aos hipossuficientes (pessoas carentes e necessitadas) e a inexistência de contrapartida por parte do beneficiário do atendimento. A fim de que se possa garantir à população saúde, previdência e assistência social, a própria Constituição Federal de 1988 elencou as formas de custeio da seguridade social. São elas: financiamento indireto, que se dá por intermédio dos recursos advindos dos orçamentos da União, dos Estados, do Distrito Federal e dos Municípios; e financiamento direito, por meio da arrecadação das contribuições sociais.

10. Conforme restou consignado ao longo do presente trabalho científico, entendemos que instituições de assistência social são aquelas pessoas jurídicas de direito 
privado que, sem fins lucrativos, dedicam-se à prestação de serviços cujos objetivos não são somente os elencados no artigo 203, da Constituição Federal de 1988. Isso porque, na nossa opinião, em razão de as instituições de assistência social auxiliarem o Estado na adoção de todas as medidas tendentes a proteger a dignidade dos hipossuficientes, para fins de reconhecimento de determinada entidade como sendo de assistência social, é irrelevante a natureza do serviço prestado. O que interessa é que o serviço possua caráter assistencial, isto é, seja vertido em favor das pessoas carentes e necessitadas.

11. No que diz respeito ao conceito de entidade beneficente de assistência social, fixamos o entendimento de que essas pessoas jurídicas são aquelas que, também sem possuir finalidade lucrativa, prestam os mesmos serviços que as instituições de assistência social, mas só que de forma gratuita.

É importante mencionar que a gratuidade dos serviços não é absoluta, mas sim relativa. Ou seja, para que determinada entidade seja considerada beneficente de assistência social ela deverá praticar a filantropia de forma parcial e não total.

12. Por força do seu enquadramento no conceito de entidade beneficente de assistência social, a entidade poderá usufruir da imunidade aos impostos, a que o artigo 150, inciso VI, alínea "c”, da Constituição Federal faz referência.

Essa hipótese de imunidade, nos termos do artigo 150, § 4 , da Carta Magna, abrange somente os impostos sobre a renda, o patrimônio e os serviços relacionados com as finalidades essenciais de tais entidades.

Entretanto, entendemos que a regra acima não se aplica somente aos impostos incidentes sobre a renda, o patrimônio e os serviços, mas sim a todos os impostos incidentes sobre a prestação de serviços ou sobre as operações mercantis praticadas pelas entidades imunes, desde que o produto dessas operações seja destinado à consecução de seu objetivo social.

E a justificativa para isso reside no fato de que a Constituição Federal de 1988, ao conceder a imunidade aos impostos às entidades beneficentes de assistência social, o fez por entender serem elevados os fins para os quais as ditas entidades foram criadas, de modo que não haveria justificativa plausível para não se imunizar todas as operações realizadas, desde que o seu resultado fosse convertido ao seu desiderato social.

13. Prosseguindo na elaboração deste trabalho científico, fixamos o entendimento de que a regra contida no artigo 150, VI, "c", por ser hipótese de imunidade tributária dita condicionada, só pode ser regulada por meio de lei complementar. 
Isso porque, tendo em vista que as imunidades tributárias enquadram-se no conceito de "Limitações Constitucionais ao Poder de Tributar" e tais limitações só podem ser veiculadas, nos termos do artigo 146, inciso II, da Constituição Federal, por intermédio de lei complementar, somente essa espécie normativa possui o condão de regulamentar a imunidade aos impostos das entidades beneficentes de assistência social.

14. Atualmente, essa lei complementar é o Código Tributário Nacional, que foi recepcionado pela Constituição Federal com status de lei complementar.

15. Em relação aos requisitos a serem preenchidos pelas entidades beneficentes de assistência social, para fins de fruição da imunidade aos impostos, temos as seguintes considerações a fazer:

15.1. No que diz respeito à impossibilidade de distribuição de qualquer parcela de seu patrimônio, a qualquer título, cumpre-nos mencionar que tal restrição não impede que as entidades imunes possuam superávit.

A justificativa para tanto reside no fato de que, diferentemente de uma pessoa jurídica de direito privado que utiliza o lucro para ampliar seus negócios, as instituições de assistência social são constituídas não para "dar lucro", mas sim para, no interesse da coletividade, auxiliar o Estado no atingimento de seus objetivos: proporcionar à população uma vida digna e saudável. Daí porque elas possuem superávit e não visam ao lucro.

15.2. A restrição contida no inciso I, do artigo 14, do Código Tributário Nacional possui como destinatário os sócios ou dirigentes da entidade imune, os quais possuem o poder de gestão e administração da sociedade.

Contudo, isso não quer dizer que eles não podem ser remunerados pelos serviços prestados. Todo o serviço prestado tem de ser remunerado, independentemente de ter sido para pessoa jurídica com ou sem fins lucrativos, uma vez que esses dirigentes, assim como qualquer outra pessoa, possuem necessidades vitais como as atreladas à segurança, educação, moradia, lazer, cultura etc.

15.3. A segunda restrição contida no artigo 14, do Código Tributário Nacional, consiste na proibição de aplicação do superávit fora do território nacional. A fim de que seja mantida a condição de entidade imune, a instituição deverá aplicar todo o seu superávit na consecução de seus objetivos sociais exclusivamente em solo brasileiro.

$\mathrm{O}$ fato de a entidade imune importar equipamentos, serviços ou custear cursos de seus integrantes em instituição de ensino estrangeira também não desvirtua a regra contida em tal 
inciso do artigo 14 do Código Tributário Nacional, uma vez que os equipamentos ou knowhow utilizados serão vertidos à consecução de seus objetivos sociais em território nacional.

15.4. Por fim, as instituições beneficentes de assistência social, em relação à imunidade aos impostos, também deverão manter escrituradas todas suas operações, sob pena de suspensão da imunidade. Todavia, tal escrituração não necessita ser pormenorizada. Basta que permita ao Fisco verificar que os requisitos contidos nos incisos I e II foram devidamente cumpridos.

16. Afora a imunidade aos impostos, as entidades beneficentes de assistência social possuem o direito à fruição de outra espécie de imunidade: às contribuições sociais destinadas à seguridade social, a que o artigo $195, \S 7^{\circ}$, da Constituição Federal faz alusão. Em relação a esse mote, entendemos que essa hipótese imunitória se aplica, outrossim, às instituições educacionais que disponibilizam seus serviços, de forma gratuita, à parcela mais carente da população.

Isso porque, no nosso entendimento, o legislador constituinte ao positivar a regra do artigo $195, \S 7^{\circ}$, da Constituição Federal, pretendeu prover os hipossuficientes de todos os meios tendentes a auxiliá-los na mudança de sua condição de pessoa carente e desprovida de recursos para autossuficiente. E uma dessas maneiras é justamente pela educação, por meio da qual o hipossuficiente terá condições de progredir em sua vida profissional e pessoal.

17. Adentrando no estudo das contribuições sociais destinadas à seguridade social, firmamos o entendimento de que essa figura, além de possuir natureza tributária, caracterizase como espécie autônoma de tributo.

Sob nossa ótica, a Constituição Federal de 1988 contempla cinco espécies tributárias: impostos; taxas; contribuições de melhoria; contribuições; e empréstimos compulsórios.

Com a promulgação da Constituição Federal de 1988, o legislador constituinte elevou a questão da destinação da receita e da restituição do tributo à condição de atributos fundamentais da estrutura dos tributos elencados no Texto Constitucional.

Dessa forma, em razão do relevo dado a esses dois atributos, entendemos que o legislador constituinte de 1988 criou mais duas figuras tributárias: as contribuições e os empréstimos compulsórios.

18. Não obstante o legislador constitucional dispor no artigo 195 , $\S 7^{\circ}$ que são “isentas" às contribuições sociais destinadas à seguridade social as entidades beneficentes de assistência social, entendemos que se trata de hipótese imunitória e não isentiva, já que atua em âmbito constitucional e não infraconstitucional. 
19. No que tange ao instrumento normativo adequado a estabelecer os requisitos a serem preenchidos para fins de fruição da imunidade às contribuições sociais destinadas à seguridade social das entidades beneficentes de assistência social, entendemos que a lei complementar é o instrumento normativo adequado para tanto.

Primeiro, porque o artigo $195, \S 7^{\circ}$ ao tratar de legítima hipótese de imunidade, constitui-se em "limitação constitucional ao poder de tributar", a qual só pode ser regulada por meio de lei complementar, nos exatos termos do artigo 146, inciso II, da Constituição.

Apesar de o artigo $195, \S 7^{\circ}$, em tese, não ter sido regulamentado até o momento, tal regra possui aplicabilidade imediata e eficácia contida.

Aplicabilidade imediata porque as normas que tratam das imunidades tributárias receberam do legislador constituinte carga normativa suficiente para sua imediata observância. E eficácia contida, uma vez que o legislador constituinte determinou o preenchimento de alguns pressupostos, visando à fruição do benefício constitucional.

19.1. Por conta de sua eficácia contida, os efeitos das normas imunizantes são irradiados assim que as pessoas, coisas ou situações se enquadrarem nas hipóteses imunitórias contidas no Texto Constitucional.

Ante a ausência dessa norma regulamentadora, entendemos que o artigo 14, do Código Tributário Nacional, possui o condão de regulamentar a fruição da imunidade às contribuições sociais destinadas à seguridade social, porquanto tal normativo foi recepcionado pela Constituição Federal de 1988 como lei complementar.

19.2. Apesar de o artigo 14, do Código Tributário Nacional fazer referência somente aos impostos, entendemos ser ele plenamente aplicável ao gozo da imunidade às contribuições sociais destinadas à seguridade social das entidades beneficentes de assistência social, pois quando da edição do Código Tributário Nacional o ordenamento jurídico não contemplava a figura das contribuições sociais destinadas à seguridade social. Além disso, na hipótese de inexistir regra específica sobre determinado assunto, a legislação tributária permite o uso da analogia, visando ao preenchimento de lacunas existentes no sistema.

20. Não concordamos com o posicionamento de que a lacuna deixada pelo artigo $195, \S 7^{\circ}$ foi preenchida pelo artigo 55, da Lei $\mathrm{n}^{\circ} 8.212$, de 1991.

Naquilo que o 55 da Lei $n^{\circ}$ 8.212. de 1991 conflitar com o artigo 14, do Código Tributário Nacional, ele será inconstitucional.

21. Entendemos que o artigo 29, da Lei $\mathrm{n}^{\circ} 12.101$, de 30 de novembro de 2009, norma jurídica que revogou o artigo 55, da Lei $\mathrm{n}^{\circ}$ 8.212, também padece do vício de 
inconstitucionalidade, porquanto, ao estabelecer requisitos outros além dos dispostos no artigo 14, do Código Tributário Nacional, esse artigo infringiu os artigos 146, inciso II, e 195, $\S 7^{\circ}$, da Constituição Federal, de modo que ele deve ser declarado inconstitucional. 


\section{REFERÊNCIAS}

AMARO, Luciano. Imunidades tributárias. In: MARTINS, Ives Gandra da Silva (coord.). Imunidades tributárias. São Paulo: Revista dos Tribunais, 1998.

ATALIBA, Geraldo. Hipótese de incidência tributária. São Paulo: Malheiros, 2014. - Limitações constitucionais ao poder de tributar. In: Revista de Direito Tributário, v. 62, São Paulo: Malheiros, 1992.

. Normas gerais de direito financeiro e tributário e autonomia dos estados e municípios: limites à norma geral: código tributário nacional. In: Revista de Direito Público, v. 3. São Paulo: Revista dos Tribunais, 1969.

. Sistema constitucional tributário. São Paulo: Revista dos Tribunais, 1968.

. O Direito Tributário e a Autonomia dos Estados-membros e Municípios. In: Revista de Direito Público. São Paulo: RT, p. 20-56.

ÁVILA, Humberto. Sistema constitucional tributário. 5. ed. São Paulo: Saraiva, 2012.

BALEEIRO, Aliomar; DERZI, Misabel Abreu Machado. Limitações constitucionais ao poder de tributar. 8. ed. Rio de Janeiro: Forense, 2010.

Imunidades e isenções tributárias. In: Revista de Direito Tributário $n$. 1, São Paulo: Malheiros, 1977. p. 67-100.

BALERA, Wágner; MUSSI, Cristiane Miziara. Direito previdenciário série concursos públicos. 7. ed. São Paulo: Método, 2010.

BARBOSA, Rui. Oração aos Moços. 5. ed. Rio de Janeiro: Fundação Casa de Rui Barbosa, 1997. Edição popular anotada por Adriano da Gama Kury.

BARRETO, Aires Fernandino; BARRETO, Paulo Ayres. Imunidades tributárias: limitações constitucionais ao poder de tributar. 2. ed. São Paulo: Dialética, 2001.

BARRETO, Paulo Ayres. Contribuições: regime jurídico, destinação e controle. 2. ed. São Paulo: Noeses, 2011.

Emenda Constitucional. In: Revista dos Tribunais $n^{o}$ 21, ano 5. São Paulo: Editora Revista dos Tribunais, out/dez de 1997, p. 160-174.

BARROSO, Luís Roberto. Interpretação e aplicação da Constituição. São Paulo: Saraiva, 1996.

BASTOS, Celso Ribeiro; MARTINS, Ives Gandra da Silva. Comentários à Constituição do Brasil. São Paulo: Saraiva, 1990, vol. 6, tomo I.

BECKER, Alfredo Augusto. Teoria geral do direito tributário. 5. ed. São Paulo: Noeses, 2010.

BOMFIM, Diego. Tributação \& livre concorrência. São Paulo: Saraiva, 2011.

BONAVIDES, Paulo. Curso de Direito Constitucional. São Paulo: Malheiros, 2007. 
BORGES, José Souto Maior. Teoria geral da isenção tributária. 3. ed. São Paulo: Malheiros, 2007.

. Lei Complementar Tributária. São Paulo: Revista dos Tribunais, 1975.

BOTTALLO, Eduardo Domingos. Imunidade de Instituições de Educação e de Assistência Social e Lei Ordinária - um Intricado Confronto. In: ROCHA, Valdir de Oliveira. Imposto de Renda: Alterações Fundamentais. São Paulo: Dialética, 1998, p. 51-63.

CAMPOS, Diogo Leite; CAMPOS, Mônica Horta Neves. Direito tributário. 2. ed. Coimbra: Almedina, 2000.

CANOTILHO, José Joaquim Gomes. Direito constitucional. 6. ed. Coimbra: Almedina, 1993.

CANTO, Gilberto de Ulhôa. Imunidade tributária - entidades fechadas de Previdência Privada (Fundos de Pensão). In: Revista de Direito Tributário $n^{\circ}$ 61. São Paulo: Malheiros, 1994. p. 17-39.

CARRAZA, Roque Antonio. A imunidade tributária das fundações de direito privado, sem fins lucrativos. Brasília: Rosseto, 2006.

2013.

Curso de Direito Constitucional Tributário. 29. ed. São Paulo: Malheiros,

CARVAlHO, Aurora Tomazini. Curso de Teoria Geral do Direito. São Paulo: Noeses, 2010.

CARVAlHO, Paulo de Barros. Curso de Direito Tributário. 26. ed. São Paulo: Saraiva, 2014.

Direito tributário: fundamentos jurídicos da incidência. São Paulo: Saraiva, 2008.

Direito tributário linguagem e método. São Paulo: Noeses, 2009.

. Imunidades condicionadas e suspensão de imunidades: análise dos requisitos

do art. 14 do CTN impostos às instituições de educação sem fins lucrativos. In: Revista de Direito Tributário n. 99, São Paulo: Malheiros, 2007, p. 07-20.

. Estatuto do contribuinte, direitos, garantias individuais em matéria tributária e limitações constitucionais nas relações entre fisco e contribuinte. Vox Legis, São Paulo, v. 141, n. 1, 1978.

CEZNE, Andréa Nárriman. Assistência Social e regulamentação estatal: análise do papel das titulações das entidades assistenciais na concessão das imunidades tributárias. In: Revista da Ajuris - Associação dos Juízes do Rio Grande do Sul, Porto Alegre, n. 107, 2007, p. 31-56.

CHIESA, Clélio. Imunidade tributária das instituições sem fins lucrativos no tocante a impostos e contribuições destinadas a financiar a Seguridade Social. In: SCHOUERI, Luís Eduardo (coord.). Direito tributário - homenagem a Paulo de Barros Carvalho. São Paulo: Quartier Latin, 2008, p. 145-172. 
COÊLHO, Sacha Calmon Navarro. Curso de Direito Tributário Brasileiro. 10. ed. Rio de Janeiro: Forense, 2009.

. Princípios Constitucionais em Matéria Tributária: Explícitos, Derivados e Conexos. In: Princípios constitucionais fundamentais: um estudo em homenagem ao professor IVES GANDRA DA SILVA MARTINS. São Paulo: Lex, 2005, p.

CÔELHO, Sacha Calmon Navarro; DERZI, Misabel Abreu Machado. A Imunidade Tributária da Caixa de Assistência da Ordem dos Advogados - OAB. In: Revista Dialética de Direito Tributário, São Paulo, n. 102, 2010, p. 145-160.

COSTA, Alcides Jorge. A efetiva aplicação da imunidade de livros, jornais, periódicos e papel destinado à sua impressão. In: Revista Direito Tributário Atual, São Paulo, v. 17, 2003, p. 13-19.

COSTA, Regina Helena. Imunidades tributárias - teoria e análise da jurisprudência do STF. 2. ed. São Paulo: Malheiros, 2006.

. Princípio da capacidade contributiva. 3. ed. São Paulo: Malheiros, 2003.

CRETELLA JÚNIOR, José. Elementos de direito constitucional. 4. ed. São Paulo: Revista dos Tribunais, 2000.

DANTAS, Ivo. Princípios constitucionais e interpretação constitucional. Rio de Janeiro: Lumen Juris, 1995.

FALCÃO, Amílcar de Araújo. Imunidade e isenção tributária - instituição de assistência social. In: Revista Direito Administrativo, Rio de Janeiro, v. 66, 1961, p. 367-375.

GRECO, Marco Aurélio. Imunidades Tributárias. In: MARTINS, Ives Gandra da Silva (coord.). Imunidades Tributárias. São Paulo: Revista dos Tribunais, 1998, p. 710-721. . Contribuições (uma figura sui generis). São Paulo: Dialética, 2000.

. As contribuições na Constituição brasileira: ainda sobre a relevância da destinação do produto da sua arrecadação. In: Revista de Direito Tributário $n^{o}$ 100. São Paulo: Malheiros, 2008, p. 122-129. Latin, 2012.

HORVATH JÚNIOR, Miguel. Direito Previdenciário. 9. ed. São Paulo: Quartier

KELSEN, Hans. Teoria Pura do Direito. 6. ed. Tradução de João Baptista Machado. São Paulo: Martins Fontes, 1998.

LIMA, Maria Ednalva de. Os dois problemas da imunidade das contribuições sociais securitárias. In: Revista Dialética de Direito Tributário, São Paulo, vol. 191, ago. 2011, p. 3950 .

MACHADO, Hugo de Brito. Comentários ao Código Tributário Nacional. Vol. 1. São Paulo: Atlas, 2003.

. Imunidade Tributária das Instituições de Educação e de Assistência Social e a Lei $\mathrm{n}^{\circ}$ 9.532. In: ROCHA, Valdir de Oliveira (coord.). Imposto de Renda: Alterações 
Fundamentais. São Paulo: Dialética, 1998.

Lei Complementar Tributária. São Paulo: Malheiros, 2010.

MARTINEZ, Wladimir Novaes. Natureza jurídica da contribuição previdenciária na Carta Magna de 1988. In: Rocha, Valdir de Oliveira (coord.). Contribuições previdenciárias: questões atuais. São Paulo: Dialética, 1996.

MARTINS, Ives Gandra da Silva. Imunidades Tributárias. In: (coord.). Imunidades tributárias. São Paulo: Revista dos Tribunais, 1998. . Comentários à Constituição do Brasil. Tomo 1, vol. 6. São Paulo: Saraiva, 1990. Imunidades Tributárias e as Leis Complementares, Ordinárias e Federais. In: Revista Direito Tributário Atual n. 23. São Paulo: Dialética, 2009.

MÉLEGA, Luiz. Regime jurídico das contribuições na Carta Política de 1988. In: Direito Tributário Atual v. 11/12. São Paulo: Resenha Tributária, 1992.

MELLO, Celso Antônio Bandeira. Controle judicial dos atos administrativos. In: Revista de Direito Público, São Paulo, v. 153, 1986.

MELlO, Oswaldo Aranha Bandeira de. Teoria das Constituições rígidas. 2. ed. São Paulo: José Bushatsky, 1980.

MELO, José Eduardo Soares de. Curso de Direito Tributário. São Paulo: Dialética, 1997. p. 89.

MICHAELIS. Moderno Dicionário da Língua Portuguesa. São Paulo: Melhoramentos, 2002.

MORAES, Alexandre de. Direito Constitucional. São Paulo: Atlas, 2007.

MORAES, Bernardo Ribeiro. A imunidade tributária e seus novos aspectos. In: Revista Dialética de Direito Tributário no 34. São Paulo: Dialética, 1998.

MOSQUEIRA, Roberto Quiroga; SOUZA, Flávia Regina de. O terceiro setor eo direito. In: Terceiro Setor Planejamento e Gestão. São Paulo: Editora Senac, 2004.

NOGUEIRA, Ruy Barbosa. Imunidades contra impostos na Constituição anterior e sua disciplina mais completa na Constituição de 1988. 2. ed. São Paulo: Saraiva, 1992.

Da interpretação e da aplicação das leis tributárias. 2. ed. São Paulo: Revista dos Tribunais, 1974.

PAULSEN, Leandro. Direito tributário: Constituição e Código Tributário à luz da doutrina e da jurisprudência. 15. ed. Porto Alegre: Livraria do Advogado, 2013.

PESTANA, Márcio. O princípio da imunidade tributária. São Paulo: Editora Revista dos Tribunais, 2001. 
ROCHA, Valdir de Oliveira. Contribuições Sociais. In: MARTINS, Ives Gandra da Silva (coord.). Caderno de Pesquisas Tributárias, v.17. São Paulo: Resenha Tributária, 1992.

SANTI, Eurico Marcos Diniz de. Imunidade tributária como limite-objetivo e as diferenças entre "livro" e "livro eletrônico". MACHADO, Hugo de Brito (org.). In: Imunidade tributária do livro eletrônico. 2. ed. São Paulo: Malheiros, 2003. p. 55-67.

SCHERER, Leandro Pacheco. Considerações acerca da imunidade tributária das entidades beneficentes de assistência social. In: Revista de Estudos Tributários, Porto Alegre, v. 7, n. 39, 2004.

SCHOUERI, Luís Eduardo. Direito tributário. 2. ed. São Paulo: Saraiva, 2012. Imunidade tributária e ordem econômica. In: ROCHA, Valdir de Oliveira (coord.). Grandes questões atuais do direito tributário, v. 11. São Paulo: Dialética, 2007. p. 241-271.

A Imunidade tributária dos cemitérios: templos de qualquer culto. In: Revista de Direito Tributário Atual, São Paulo, n. 21, 2007, p. 254-281.

SILVA, José Afonso da. Curso de Direito Constitucional Positivo. São Paulo: Malheiros, 2006.

SOUSA, Rubens Gomes de. Compêndio de legislação tributária. ed. póstuma. São Paulo: Resenha Tributária, 1975.

TOMÉ, Fabiana Del Padre. Contribuições para a Seguridade Social à luz da Constituição Federal. 2. ed. Curitiba: Juruá, 2013.

- Alcance da imunidade das receitas de exportação (art. 149, 20 I, da Constituição): a questão da Contribuição Social sobre o Lucro Líquido. In: COÊLHO, Sacha Calmon Navarro (Org.). Contribuições para Seguridade Social. Vol. 1. São Paulo: Quartier Latin, 2007, p. 319-336.

TORRES, Heleno Taveira. Direito constitucional tributário e segurança jurídica: metódica da segurança jurídica do sistema constitucional tributário. São Paulo: Revista dos Tribunais, 2011.

fins lucrativos. In:

Teoria da Norma de Imunidade Tributária e sua aplicação às entidades sem 60 anos da $A B D F$. São Paulo: Quartier Latin, 2010, p. 159-198.

TORRES, Ricardo Lobo. Imunidades Tributárias. In: Ives Gandra da Silva Martins (coord.). Imunidades Tributárias. São Paulo: Revista dos Tribunais, 1998, p. 183-222.

XAVIER, Alberto. Princípios do processo administrativo e judicial tributário. Rio de Janeiro: Forense, 2005. 